THE INTERTEXTUAL RECEPTION OF GENESIS 1-3 IN IRENAEUS OF LYONS

\author{
Stephen 0. Presley
}

A Thesis Submitted for the Degree of PhD at the University of St Andrews

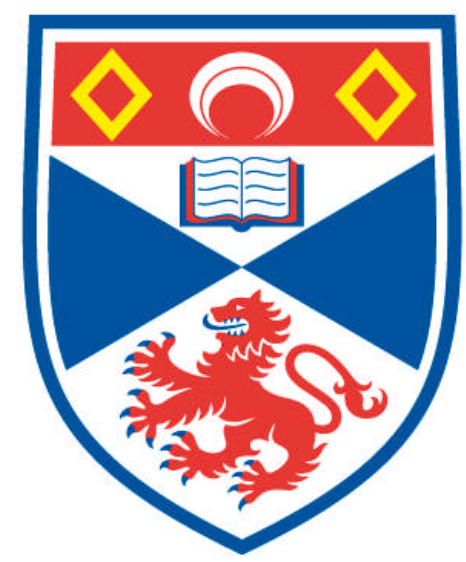

2012

Full metadata for this item is available in Research@StAndrews:FullText at:

http://research-repository.st-andrews.ac.uk/

Please use this identifier to cite or link to this item: http://hdl.handle.net/10023/3167

This item is protected by original copyright 


\title{
THE INTERTEXTUAL RECEPTION OF GENESIS 1-3 IN IRENAEUS OF LYONS
}

\author{
STEPHEN O. PRESLEY
}

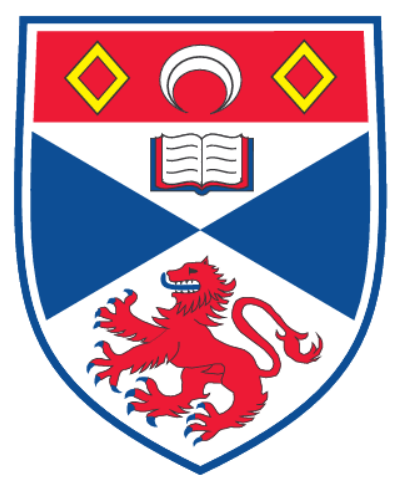

This thesis is submitted in partial fulfilment for the degree of Ph.D. at the

University of St. Andrews

September 2011 


\section{Candidate's declarations:}

I, Stephen Presley, hereby certify that this thesis, which is approximately 80,000 words in length, has been written by me, that it is the record of work carried out by me and that it has not been submitted in any previous application for a higher degree.

I was admitted as a research student in $[10,2007]$ and as a candidate for the degree of Doctor of Philosophy in $[07,2008]$; the higher study for which this is a record was carried out in the University of St Andrews between [2007] and [2011].

(If you received assistance in writing from anyone other than your supervisor/s):

I, Stephen Presley, received assistance in the writing of this thesis in respect of [language, grammar, spelling or syntax], which was provided by no one other than my supervisor.

Date $27.9 / 11$ signature of candidate

\section{Supervisor's declaration:}

I hereby certify that the candidate has fulfilled the conditions of the Resolution and Regulations appropriate for the degree of Doctor of Philosophy in the University of St Andrews and that the candidate is qualified to submit this thesis in application for that degree.

Date ...... signature of supervisor

\section{Permission for electronic publication: (to be signed by both candidate and supervisor)}

In submitting this thesis to the University of St Andrews I understand that I am giving permission for it to be made available for use in accordance with the regulations of the University Library for the time being in force, subject to any copyright vested in the work not being affected thereby. I also understand that the title and the abstract will be published, and that a copy of the work may be made and supplied to any bona fide library or research worker, that my thesis will be electronically accessible for personal or research use unless exempt by award of an embargo as requested below, and that the library has the right to migrate my thesis into new electronic forms as required to ensure continued access to the thesis. I have obtained any third-party copyright permissions that may be required in order to allow such access and migration, or have requested the appropriate embargo below.

The following is an agreed request by candidate and supervisor regarding the electronic publication of this thesis:

\section{Add one of the following options:}

(ii) Access to [all or part] of printed copy but embargo of [all or part] of electronic publication of thesis for a period of 2 years (maximum five) on the following ground(s):

publication would preclude future publication;

Date $27 / 9 / 11$ signature of candidate

signature of supervisor

A supporting statement for a request for an embargo must be included with the submission of the draft copy of the thesis. Where part of a thesis is to be embargoed, please specify the part and the reasons. 


\title{
THE INTERTEXTUAL RECEPTION OF GENESIS 1-3 \\ IN IRENAEUS OF LYONS
}

\author{
STEPHEN O. PRESLEY
}

\begin{abstract}
This thesis explores the intertextual nature of Irenaeus' reading of Genesis 1-3. In this study, we assume a different mode of investigation than previous works on Irenaeus' use of scripture. Drawing from contemporary discussions on intertextuality in Fishbane, Boyrin, Hays, and Young, we challenge a tradition of investigation into Irenaeus' exegesis that has marginalized the significance of scriptural networking inherent to his hermeneutic. This perspective is evident in the previous works on Irenaeus' reading of Genesis in Orbe, Jacobsen, Kannengiesser, Steenberg, and Holsinger-Friesen. This thesis, on the other hand, brings together an appreciation for Irenaeus' hermeneutic with respect to his exegesis of Gen 1-3. We show that in every instance Irenaeus interprets Gen 1-3, not in isolation, but in correlation with other texts by means of a variety of intertextual reading strategies that shape his theological polemic.

In chapter one we investigate the nature of Irenaeus' hermeneutical orientation based upon studies of patristic exegesis and his own descriptions of the exegetical task. We show that Irenaeus purposes to interconnect texts in his refutation and exegesis and we formulate a methodology that appreciates his reading of Gen 1-3 within this theological networking of texts. In chapters 2-6, we provide a literary analysis of the echoes, allusions, and citations of Gen 1-3 in each book of Adversus Haereses. In each case we isolate the allusions to Gen 1-3 and the corresponding interrelated texts that form a hermeneutically symbiotic relationship with Gen 1-3. We show how these textual relationships yield a more comprehensive appreciation for the meaning and function of Gen 1-3 in Irenaeus. In chapter 7 we conclude with a summary and cumulative evaluation of the intertextual relationships fashioned with Gen 1-3 and the reading strategies that guide his intertextual use of Gen 1-3. In doing so, this thesis exposes the intricacies of Irenaeus' theological and intertextual reading of Gen 1-3 and the various ways that Irenaeus harmonizes scripture.
\end{abstract}


The copyright of this thesis rests with the author. No quotation from it should be published in any format, including electronic, without the author's prior written permission. All information derived from this thesis must be acknowledged appropriately.

\section{DECLARATION}

This work has been submitted to the University of Saint Andrews in accordance with the regulations for the degree of Doctor of Philosophy. It is my own work, and none of it has been previously submitted to the University of Saint Andrews or in any other university for a degree. 
References to Adversus Haereses

Quotations of AH 1-5 are taken from Sources Chretiennes. Translations were made in consultation with The Ante-Nicene Fathers vol. 1, but language has been updated.

References to Scripture

References to the LXX were made in consultation with the Ralphs' LXX and New Testament references are taken from Novum Testamentum Gracece, Nestle-Aland, $26^{\text {th }}$ edition. 


\section{CONTENTS}

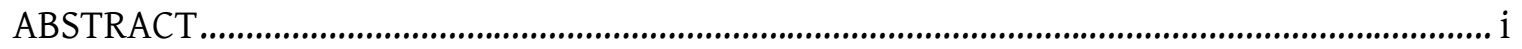

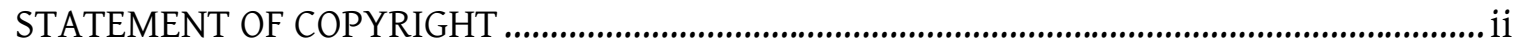

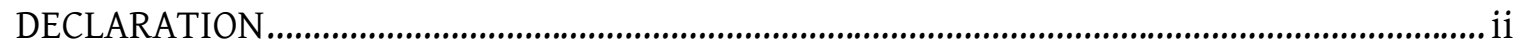

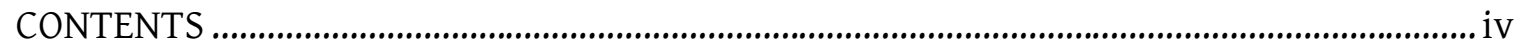

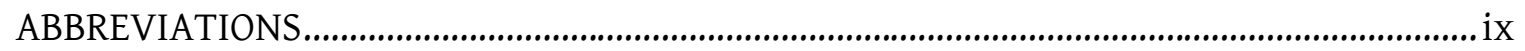

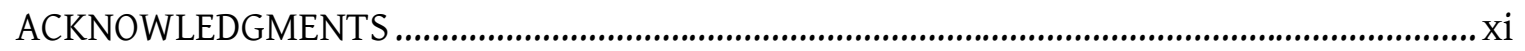

CHAPTER 1: INTRODUCTION

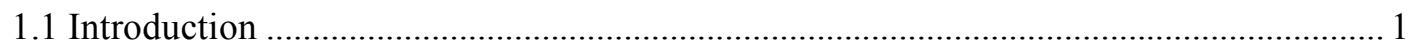

1.2 The Intertextual Nature of Irenaeus' Hermeneutics........................................................ 4

1.3 Intertextuality in Modern Biblical Studies and the Ancient World ................................. 14

1.4 Toward an Intertextual Appreciation for Genesis 1-3 in Irenaeus .................................. 19

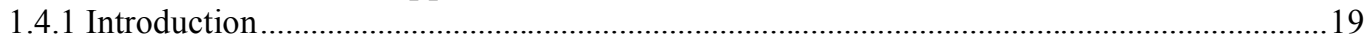

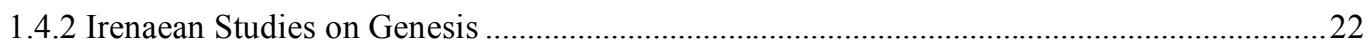

1.4.3 Antonio Orbe, Charles Kannengiesser and Anders-Christian Jacobsen ................................24

1.4.4 Matthew Steenberg and Thomas Holsinger-Friesen ............................................................2.

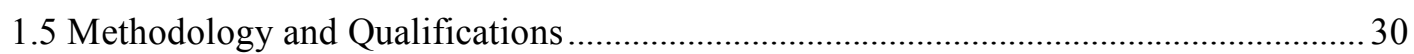

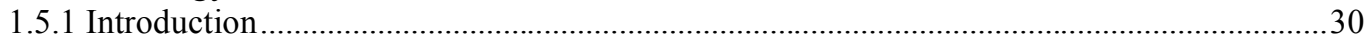

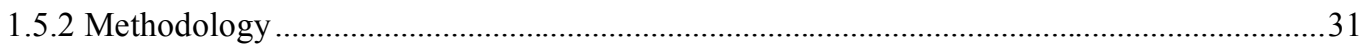

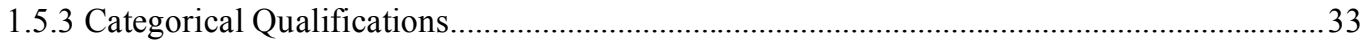

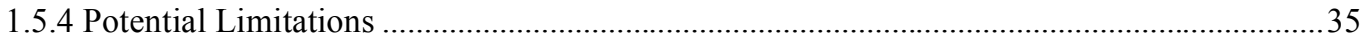

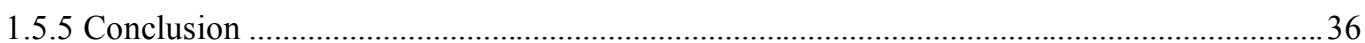

CHAPTER 2: THE INTERTEXTUAL RECEPTION OF GENESIS 1-3 IN BOOK 1 OF ADVERSUS HAERESES

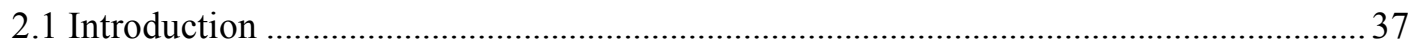

2.2 AH 1.5.1-6: Valentinians on Creation (Gen 2:5, Gen 2:7, Gen 3:21) ........................... 39

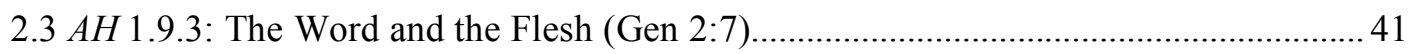

2.4 AH 1.14.6: Marcus and the Sixth Day (Gen 1:31) ....................................................... 42

2.5 AH 1.18.1-4: The Marcosians on Creation (Gen 1:2, Gen 1:3-27, Gen 1:26, Gen 2:10)

2.6 AH 1.22.1: Creation and The Regula Veritatis (Gen 1:1, Gen 2:7) ................................. 45

2.7 AH 1.24.1-2: Saturninus on Creation (Gen 1:26, Gen 2:7, Gen 3:19) ............................. 46

2.8 AH 1.28.1: Asceticism in Tatian and the Encratites (Gen 1:27-8) ................................. 47

2.9 AH 1.30.1-9: The Ophites on Creation (Gen 1:2, Gen 1:7-8, Gen 1:26, Gen 2:7, Gen

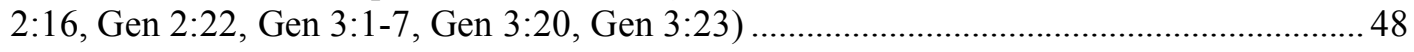

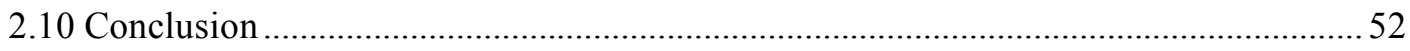

CHAPTER 3: THE INTERTEXTUAL RECEPTION OF GENESIS 1-3 BOOK 2 OF ADVERSUS HAERESES..

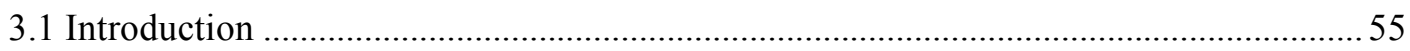

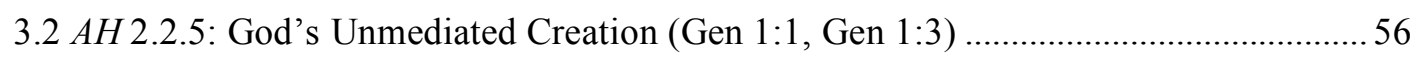

3.3 AH 2.26.1: Knowledge and Love (Gen 2:7) f.............................................................. 57 
3.4 AH 2.28.1: Creation and Providence (Gen 1:1, Gen 2:7, Gen 1:28).............................. 58

3.5 AH 2.30.7: Paul's Rapture to Paradise (Gen 1:1, Gen 2:7, Gen 2:15) ..........................59

3.6 AH 2.30.9: Creation by the Word and Wisdom (Gen 1:1, Gen 2:7, Gen 2:8) ............... 60

3.7 AH 2.34.3-4: Formation and Progression of Body and Soul (Gen 2:1, Gen 2:7) ..........61

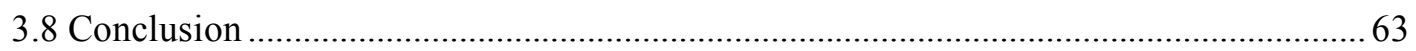

CHAPTER 4: THE INTERTEXTUAL RECEPTION OF GENESIS 1-3 IN BOOK 3 OF

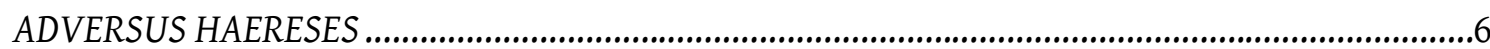

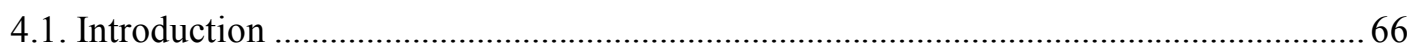

4.2 AH 3.3.3: The Narrative of Salvation (Gen 1:1, Gen 2:7) …........................................... 67

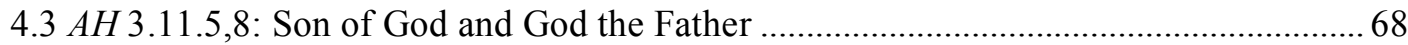

4.3.1 AH 3.11.5: Creation and Blessing (Gen 1:1, Gen 1:9, Gen 1:11, Gen 2:6) ...........................69

4.3.2 AH 3.11.8: The Adamic Covenant (Gen 2:16-17) …………………………………….......69

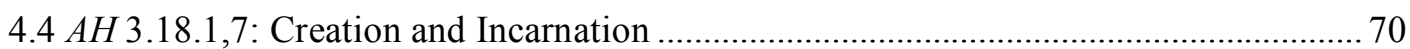

4.4.1 AH 3.18.1: The Pre-existence of the Son (Gen 1:26, Gen 2:7) ……………………...........71

4.4.2 AH 3.18.7: Salvation and the Obedience of Christ (Gen 2:5) ................................................72

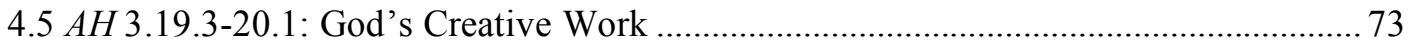

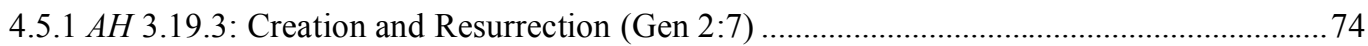

4.5.2 AH 3.20.1: Human Disobedience and God's Creative Work (Gen 3:1-8)...........................75

4.6 AH 3.21.10: Adam, Christ, and Recapitulation (Gen 1:26, Gen 2:5, Gen 2:7) ............... 77

4.7 AH 3.22.1-4: The Typology of Adam, Christ, Eve, and Mary …………………........... 80

4.7.1 AH 3.22.1: The Blessed Meekness of the Flesh (Gen 1:26, Gen 2:7)................................. 81

4.7.2 AH 3.22.2-3: Christ's Body and Adam's body (Gen 2:7) .............................................. 82

4.7.3 AH 3.22.4: From Adam and Christ to Eve and Mary (Gen 1:28, Gen 2:25, Gen 3:6)...........83

4.8 AH 3.23.1-8: The Salvation and the Formation from the Dust ..................................... 89

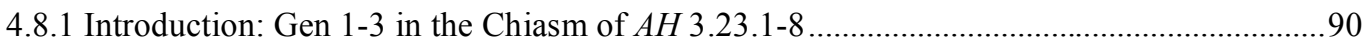

4.8.2 AH 3.23.1: (A) The Serpent's Deception and the Hope of Salvation (Gen 1:26, Gen 3:5)...92

4.8.3 AH 3.23.2: (B) Adam Requires Salvation (Gen 1:26)......................................................93

4.8.4 AH 3.23.3: (C) God Curses Adam, Eve and the Serpent (Gen 3:14, Gen 3:16, Gen 3:17-19)

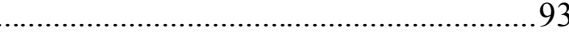

4.8.5 AH 3.23.4: (D) Cain's Insolence (Gen 4:7-8, Gen 4:9, Gen 4:11) .....................................94

4.8.6 AH 3.23.5: (D') Adam's Humility (Gen 3:7-8, Gen 3:10, Gen 3:13, Gen 3:21) ...................95

4.8.7 AH 3.23.6: (C') God's Compassion in Adam's Expulsion (Gen 2:9, Gen 3:23-24) .............96

4.8.8 AH 3.23.7: (B') The Protoevangelium Fulfilled in Christ (Gen 3:15) ..................................96

4.8.9 AH 3.23.8: (A') The Continuation of the Serpent's Actions (Gen 3:5) ...................................99

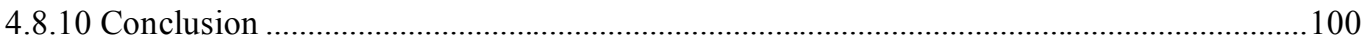

4.9 AH 3.24.1-2: The Church, the Spirit, and the Knowledge of God ................................ 101

4.9.1 AH 3.24.1: The Church, the Body and the Spirit (Gen 2:7)...............................................101

4.9.2 AH 3.24.2: Knowledge of the Creator (Gen 1:26, Gen 1:28, Gen 2:7) ……………...........102

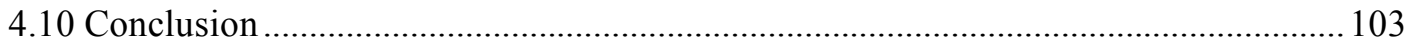

CHAPTER 5: THE INTERTEXTUAL RECEPTION OF GENESIS 1-3 IN BOOK 4 OF ADVERSUS HAERESES

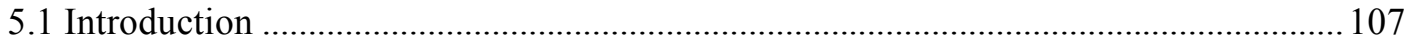

5.2 AH 4.pf.3-4: The Heretics and Gen 1-3 (Gen 1:26, Gen 2:7, Gen 3:1-5),................... 108

5.3 AH 4.6.2: The Son and the Father (Gen 1:26, Gen 1:28, Gen 2:7) .............................. 110

5.4 AH 4.10.1: The Son Inquiring after Adam (Gen 3:9) ................................................ 111

5.5 AH 4.11.1-2: The Prophets and Salvation History (Gen 1:28).................................... 112 
5.6 AH 4.14.1: Why God Created Humankind (Gen 2:7)...

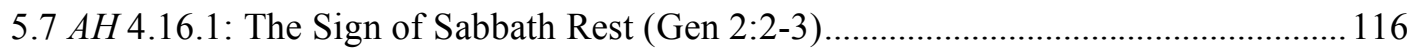

5.8 AH 4.20.1-4a: Supremacy over All Things (Gen 1:26, Gen 2:7) ................................ 117

5.9 AH 4.32.1: Word of God and the Unity of Scripture (Gen 1:3) .................................. 122

5.10 AH 4.33.4: Ebionites and the Incarnation (Gen 1:26; Gen 2:7) ................................ 124

5.11 AH 4.34.4: Christ the Pruning hook (Gen 2:7, Gen 3:17-8) ....................................... 126

5.12 AH 4.36.2-6: Christ's Parables and Adam (Gen 2:7)................................................ 128

5.13 AH 4.37.4: Image, Likeness, and Freedom (Gen 1:26) ............................................. 130

5.14 AH 4.38.1-4: Perfection in the Image and Likeness of God....................................... 131

5.14.1 AH 4.38.1-2: Ascendancy Toward Perfection (Gen 2:7) ................................................132

5.14.2 AH 4.38.3: Growth, Perfection, and the Original Creation (Gen 1:26, Gen 1:28, Gen 2:7)

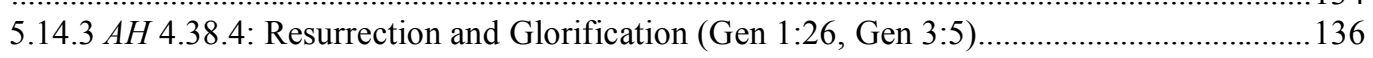

5.15 AH 4.39.2: God Makes, Humanity is Made (Gen 2:5, Gen 2:7) ................................. 138

5.16 AH 4.40.3: The Eschatological Judgment (Gen 3:15) ............................................. 140

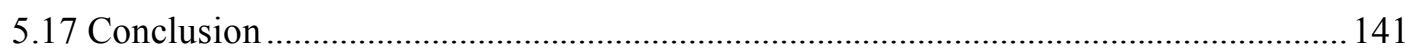

CHAPTER 6: THE INTERTEXTUAL RECEPTION OF GENESIS 1-3 IN BOOK 5 OF ADVERSUS HAERESES

6.1 Introduction ..... 145

6.2 AH 5.1.1-3: Valentinians, Ebionites, Adam and Christ (Gen 1:26, Gen 2:7, Gen 3:1-6, Gen 3:24) 146

6.3 AH 5.2.1: Marcion and the Salvation of Another's Property (Gen 1:26) ...................... 152

6.4 AH 5.3.2-3: The Power of God the Weakness of the Flesh (Gen 2:7)......................... 153

6.5 AH 5.5.1-2: The Flesh in the Hands of God (Gen 2:7, Gen 2:8, Gen 2:15, Gen 3:23) 156

6.6 AH 5.6.1: Perfection in the Image and Likeness (Gen 1:26, Gen 2:7) ........................ 157

6.7 AH 5.7.1-2: The Narrative of Resurrection (Gen 2:7, Gen 3:19) ................................. 160

6.8 AH 5.8.1: The Spirit and the Image and Likeness (Gen 1:26) .................................... 162

6.9 AH 5.10.1: The Olive Tree and the Image and Likeness (Gen 1:26)........................... 163

6.10 AH 5.12.1-6: The Breath of Life and the Spirit (Gen 1:26, Gen 2:7) ......................... 164

6.11 AH 5.14.1-2: The Reconciling Flesh of Christ (Gen 2:7)......................................... 168

6.12 AH 5:15.2-16.2: Creation, Resurrection and the Healing of the Blind Man ............... 170 6.12.1 AH 5.15.2: The Work of God and the Formation of Humanity (Gen 2:7) .......................171

6.13.1 AH 5.15.3: Christ the Creator (Gen 2:7) ………………………………………...... 174

6.12.2 AH 5.15.4: The Consistency of Creation (Gen 1:26, Gen 2:7, Gen 3:8-9) .......................175

6.12.3 AH 5.16.1: Bodies Made of Earth (Gen 1:26, Gen 2:7, Gen 3:19) ……………….........176

6.12.4 AH 5.16.2: Christ, the Spirit, and the Image and Likeness (Gen 1:26, Gen 2:7) ..............177

6.13 AH 5.16.3: Christ's Passion and Adam's Disobedience (Gen 2:17, Gen 3:6) ........... 180

6.14 AH 5.17.1-4: Restoration and Friendship at the Tree .............................................. 181

6.14.1 AH 5.17.1-2: Restoration and Friendship with God (Gen 2:17, Gen 3:8) ..........................181

6.14.2 AH 5.17.3-4: Disobedience and Restoration at the Tree (Gen 3:6)................................... 183

6.15 AH 5.19.1: The Dispensations of Adam and Christ (Gen 3:1-6, Gen 3:8) ................. 183 
6.16 AH 5.20.2: Flee to the Church and be Nourished by the Scriptures (Gen 2:8, Gen

$2: 16$, Gen $2: 17)$

6.17 AH 5.21.1-3: The Temptation of Adam and Christ (Gen 1:26, Gen 2:7, Gen 3:6, Gen $3: 15)$ 187

6.18 AH 5.23.1-2: The Day Adam Died (Gen 1:5, Gen 2:16-17, Gen 3:1-5) .................... 190

6.19 AH 5.26.2: Blasphemy Against the Creator (Gen 3:1-6)........................................ 195

6.20 AH 5.28.3-4: Irenaeus' Chiliastic Vision (Gen 1:26, Gen 2:1-2, Gen 2:7) ................. 196

6.21 AH 5.30.4: The Destruction of the Antichrist (Gen 2:2-3) ......................................... 199

6.22 AH 5.33.1-4: Resurrection and Restoration (Gen 1:27-28, Gen 1:30, Gen 2:2-3).... 199

6.23 AH 5.34.2: The Restoration of Inheritance (Gen 3:6).............................................. 201

6.24 AH 5.36.3: The Resurrection of the Just and the Final Consummation (Gen 1:26, Gen

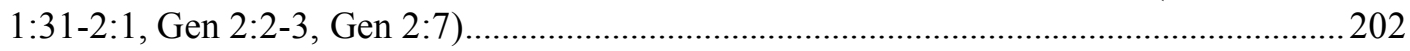

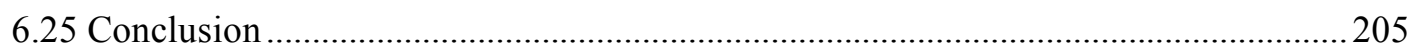

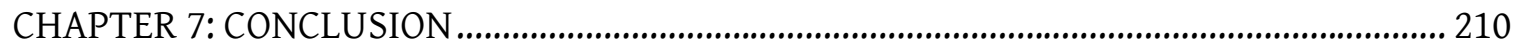

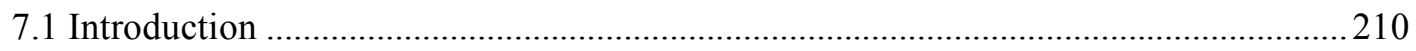

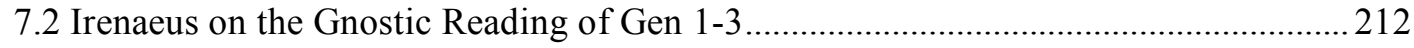

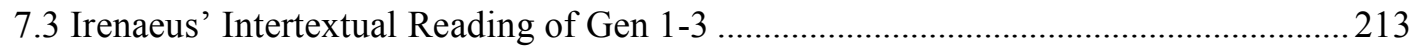

7.3.1 Organizational and Structural Function .................................................................214

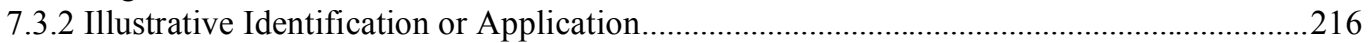

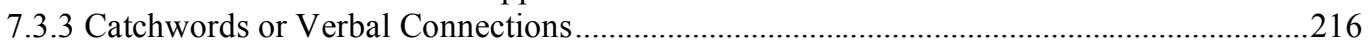

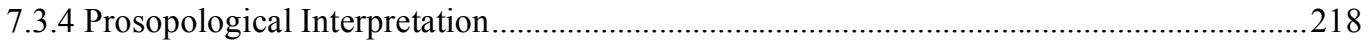

7.3.5 Literal or "Plain Sense" Reading ...........................................................................219

7.3.6 General Theological or Typological Relationships .......................................................220

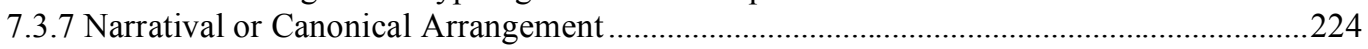

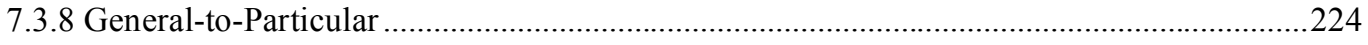

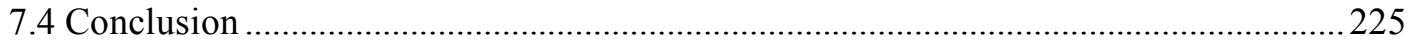

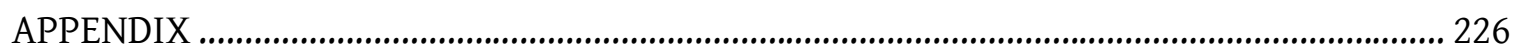

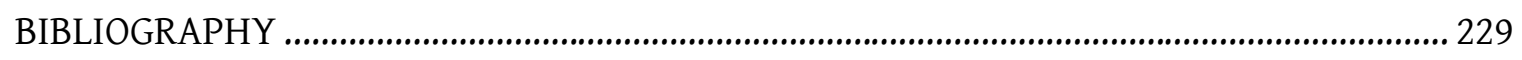


"After Adam, there are no nameless objects, nor any unused words,"

Tzvetan Todorov, Mikhail Bakhtin: the dialogical principle, $\mathrm{x}$.

"And all Scripture, which has been given to us by God, shall be found by us perfectly consistent; and the parables shall harmonize with those passages which are perfectly plain; and those statements the meaning of which is clear, shall serve to explain the parables; and through the many diversified utterances there shall be heard one harmonious melody in us, praising in hymns that God who created all things."

AH 2.28.3

"proofs in scriptures cannot be revealed except by the scriptures themselves."

AH 3.12.9 


\section{ABBREVIATIONS}

ASE Abhandlungen zur Socialethik

AH Adversus Haereses, or Against the Heresies

AHC Annuarium historiae conciliorum

AThR Anglican Theological Review

ARC ARC: Journal of Faculty Religious Studies McGill University

Aug Augustinianum

ACR Australian Catholic Record

BP Biblia Patristica

Bib Biblica

BibInt Biblical Interpretation

BJRL Biblical Journal of Religious Literature

BLE Bulletin de Literature Ecclésiastique

CBQ Catholic Biblical Quarterly

Com Communio

ETL Ephemerides Theologicae Louanienses

Epid Epideixis, or The Demonstration of Apostolic Preaching

EvQ Evangelical Quarterly

ERT Evangelical Review of Theology

Greg Gregorianum

HTR Harvard Theological Review

Irén Irénikon

JSJ Journal for the Study of Judaism

JECS Journal of Early Christian Studies

$J R \quad$ Journal of Religion

JAAR Journal of the American Academy of Religion

JTI Journal of Theological Interpretation

JTS Journal of Theological Studies

MAR Marianum

MT Modern Theology

NTA Neutestamentliche Abhandlungen

NRT Nouvelle Revue Théologique

NovT Novum Testamentum

OCP Orientalia Christiana Periodica

ORA Oxford University Research Archive

PL Philosophy and Literature

ProEc Proecclesia

RevB Revue Bénédictine

RHR Revue de l'histoire des religions

RUO Revue de l'université d'Ottawa

REA Revue des Études Augustiniennes

RSPT Revus des Sciences Philosophiques et Théologiques

RSR Revue des Sciences Religieuses

RThom Revue Thomiste

SacE Sacris Erudiri

SVTQ Saint Vladimir's Theological Quarterly

SJT Scottish Journal of Theology

SecCent Second Century

SC Sources Chrétiennes

StuEv Studia Evangelica 
SMSR Studia Materiali di Storia delle Religioni

StuM Studia Moralia

StuPat Studia Patristica

StuTh Studia Theologica

TS Theological Studies

ThLBer Theologische Literaturbericht

The Theologische Quartalschrift

VetCh Vetera Christianorum

VT Vetus Testamentum

VC Vigiliae Christianae

ZAC Zeitschrift fur Antikes Christentum 


\section{ACKNOWLEDGMENTS}

In continuity with Irenaeus' hermeneutical perspective, no portion of this project was accomplished in isolation. The seedbed of this study was planted by Jeffrey Bingham over a casual lunch conversation nearly six years ago. I am indebted to his wisdom and guidance, not only for the idea of this project, but also his support throughout the writing process. He inspired my appreciation for the Fathers and for Irenaeus in particular. His work on Irenaeus and his responses to my analysis of Irenaeus' hermeneutic continually enhanced my understanding of the Bishop's thought. I am also grateful for my supervisor, Mark Elliott, who was willing to oversee this project, and, with patience and careful reflection, endured countless drafts and revisions. His breadth of knowledge is unmatched and his insights continually served to strengthen my work. In addition, I also want to thank Nathan MacDonald who acted as a second supervisor during the early stages of writing and offered some very helpful direction. Likewise, during various seminars at St. Andrews, the faculty of St. Mary's College was gracious enough to engage Irenaeus' reading of Gen 1-3 and provide some insightful feedback.

I also want to thank the many postgraduate students who were eager dialogue partners throughout my time at St. Andrews, and continually served to sharpen my thinking and argumentation. They include: Jake Andrews, Steve Bagby, Patrick Egan, Shawn Bawulski, Anna Blanch, Sean Cook, John Edwards, Matt Farlow, Jeremy Gabrielson, Drew Lewis, Mariam Kamel, Tobias Karlowicz, Will Kynes, R. J. Matava, Jarred Mercer, Meg Ramey, Jason Sexton, David Sonju, Paul Stiles, Tim Stone, Luke Tallon, Amber and Paul Warhurst, and Jim Watkins. I am also indebted to St. Andrew's Church and Rev. David Wilson, who supported my family during our time in St. Andrews, and especially the youth group who helped to make us feel at home in Scotland. I will not soon forget the wonderful memories we shared over the years. I am also grateful to Aaron Morris, Jeff Webster, and Glenn Kreider who supported me throughout the project, but especially in the final days as I was finishing up the editing process in Dallas. Jeff's careful editorial comments on the final draft were especially helpful. The faculty and community of Southwestern Baptist Theological Seminary also provided immense support during the final days of revisions. I am also grateful for Cody Pancamo, who diligently proofread the final draft closely and offered helpful comments. 
I also want to thank my family, who with immense patience and understanding allowed me to hide away to research and write. My sister Whitney, in particular, was kind enough to read though portions and offer her editorial remarks. I am thankful for my parents, Mark and Anne Presley, and my in-laws, Richard and Cathy Thompson. Each of them supported our family in so many ways. I do regret that this project was interrupted by the death of my father, a long-time college professor in geological sciences. I am greatly saddened that he will not have the opportunity to see the finished product, but I remain thankful for his example, because he inspired my love for research and teaching.

Most of all, I recognize that this work would have never seen the light of day without the loving support of my wife Haley. Her patience knows no limits. Words cannot express my gratitude for her and anything I accomplish is due principally to her sacrifice and commitment. The timeline of this project also included the birth of our two daughters, Isla and Emma, who are the light of my life. Though daddy was constantly hiding away at his writing desk, they always welcomed me home with a smile and a cuddle. In spite of all other circumstances, the joy they gave me always kept me motivated.

Finally, even though I was surrounded by this wonderful community, any errors are solely my own. 


\section{CHAPTER 1: INTRODUCTION}

\subsection{Introduction}

This work reevaluates the methods and means of Irenaeus' hermeneutical orientation with respect to his reading of Genesis 1-3. This study, however, assumes a different mode of investigation than previous works on scriptural interpretation in the Bishop of Lyon. The premise is that the reception of any particular passage of scripture in Irenaeus necessarily includes the reception of theologically and hermeneutically interrelated passages. Irenaeus receives and interprets texts in relationship. This is not an assumption imposed upon Irenaeus, but rather clearly reflected in his own descriptions of the exegetical task and applied exegesis. Indeed, it is the lingering effects of the assumptions and methods intrinsic to Higher Criticism that have been imposed upon Irenaeus' use of scripture and have disconnected the texture of his scriptural networks in order to extract isolated sources and isolated meanings of isolated texts. ${ }^{1}$

Beginning with Gustaf Wingren, many scholars have criticized approaches to Irenaeus' theological framework that encourage fragmentation. Lamenting the divisive tendencies of earlier generation source critics, Wingren writes, "one fact is beyond dispute: none of the modern theologians who have broken up his [Irenaeus'] theology into two or more sections comes anywhere near Irenaeus as a systematic theologian." Contrary to those who disparaged Irenaeus' "primitive exegesis and obscure ideas" and applied an "atomistic system of exegetics," Wingren argues for a more systematic structure to Irenaeus' thought by means of closer attention to his

\footnotetext{
${ }^{1}$ For a summary of historical and philosophical developments of Higher Criticism see: G. A. Klingbiel, "Historical Criticism," In Dictionary of the Old Testament Pentateuch, eds T. Desmond Alexander and David Baker, 401-20 (Downers Grove, IL: InterVarsity Press, 2003). See also: Richard E. Burnett, "Historical Criticism," in Dictionary for Theological Interpretation of the Bible, eds. Kevin Vanhoozer, et al., 290-93 (Grand Rapids, MI: Baker Academic, 2005). Hans Frei summarizes the reductionistic effects of the historical-critical method saying, "As the realistic narrative reading of the biblical stories broke down, literal or verbal and historical meaning were severed and literal and figural interpretation, hitherto naturally affiliated procedures, also came apart." Frei, The Eclipse of Biblical Narrative: A Study in Eighteenth and Nineteenth Century Hermeneutics (New Haven, CT: Yale University Press, 1980), 6-7. The early chapters of Genesis in particular (along with the Gospels) received the most intense criticism. Ibid, 17.

${ }^{2}$ Gustof Wingren, Man and the Incarnation: A Study in the Biblical Theology of Irenaeus (Eugene, OR: Wipf \& Stock Publishers, 1947), 104.cf. Ibid., xi, 106-10. Antonio Orbe, Teología de San Ireneo: Comentario al Libro V del «Adversus haereses» (Madrid: Biblioteca de Autroes Crisianos, 1985), 15. Hereafter Teología V.1-3.
} 
biblical theology. ${ }^{3}$ He credits Irenaeus with the unique ability to fuse the scriptures and various authorities of the early church into a "harmonious whole." However, Wingren's search for the fundamental unity of Irenaeus' theological reflections overlooks the unifying features of his exegetical practice itself. The same tendency is perceivable in John Lawson's work that also touted Irenaeus a biblical theologian and aimed to clarify the "biblical character" of Irenaeus' theology in a more systematic manner. He remarks that even the most casual reader of Irenaeus cannot fail to observe that "chapter after chapter is nothing other than a mosaic of Biblical quotations." ${ }^{5}$ However, he also generally disparaged Irenaeus' exegesis as "most commonly allegorical." As a result, his sympathetic inquiry into the patterns of Irenaeus' thought continued to partition the harmonious nature of his scripture interpretation. ${ }^{7}$ Nevertheless, the legacy of their appreciation for Irenaeus' use of scripture initiated a generation of interest in Irenaeus as exegete.

By the late 1960's and following the work of Wingren and Lawson, Irenaean scholars began reevaluating the performance of scripture in the Bishop of Lyon as a different avenue into his thought. ${ }^{8}$ These exegetical works were less concerned with the sources lurking behind Irenaeus' writings, and focused more on appreciating Irenaeus' contribution to the history of biblical interpretation. The methodological evaluation of Irenaeus' exegesis sought to isolate his reading of particular segments of scripture, branching into his reading of individual passages, chapters, or books of scripture (especially the New Testament). While this trajectory gained momentum in the 80's and 90's and has showed no signs of slowing down, the methods of scholarly inquiry applied to Irenaeus' exegetical output continue to isolate the performance of individual scriptures or pericopes within the Bishop's theological contribution.

This present study, on the other hand, endeavors to move beyond the scriptural separatism in methodological approaches to Irenaeus' exegesis. We

\footnotetext{
${ }^{3}$ Ibid., 104, xxi; Orbe, Teología V.1, 3-6, 14-16.

${ }^{4}$ Ibid., xvi.

${ }^{5}$ John Lawson, The Biblical Theology of Saint Irenaeus (London: Epworth Press, 1948), 23.

${ }^{6}$ Ibid.

${ }^{7}$ Ibid., 55-86.

${ }^{8}$ Although the study of Irenaeus use of scripture extends back to Werner's contribution in the $19^{\text {th }}$ century, modern treatments of Irenaeus' use of scripture began with Antonio Orbe's consideration of the parables and Peretto's analysis of Romans 1-8. Orbe, Parabolas evangelicas in San Ireneo, 2 vols (Madrid: Biblioteca de Autores Cristianos, 1972); Pretto, La Lettera ai Romani, cc. 1-8, nell' "Adversus Haereses" d'Ireneo (Bari: Istituto di Litteratura Cristiana Antica, 1971).
} 
intend to do so not by abstracting an individual pericope of scripture apart from connection to other texts, but by making the interrelations the very object of our examination. For this reason our inquiry into Irenaeus' intertextual reception of Gen 1-3 begins with an assessment of his hermeneutics rather than an argument for the importance of the creation texts in Irenaeus' theological framework. To be sure, his dependence on creation passages is indisputable. It is not unusual to see Irenaeus characterized as a "theologian of creation." However, no study of Irenaeus' theology of creation evaluates the Bishops' reading of Gen 1-3 from the angle of the tissue of passages he fashions with Gen 1-3. Matthew Steenberg even recognizes that Irenaeus' view of creation ultimately hinges upon his exegetical methodology that has all too often received unwarranted ridicule in light of modern developmental models of exegesis. ${ }^{10}$ In the words of Steenberg, "it is not what one reads in scripture, but how one reads it, that forms the basis of Irenaeus' methodology," and "how" Irenaeus reads scripture is fundamentally guided by his intentional harmonization of scriptural passages. ${ }^{11}$

As we will demonstrate in this study, for Irenaeus Gen 1-3 must be interpreted within carefully constructed scriptural networks of interrelated texts. From this general analysis of Irenaeus' intertextual reception of Gen 1-3, we will argue for a particular set of conceptual descriptions that classify the kind of intertextual exegesis that guide his scriptural networking. These strategies include: an organizational and structural function, illustrative identification or application, catchwords or verbal connections, prosopological (or prosopographical) interpretation, a literal or "plain sense" reading, general theological or typological connections, narratival or canonical arrangements, and general-to-particular argumentation. From our discussion of the intertextual performance of Gen 1-3 in Irenaeus, we will see how he consistently applies these networking practices in order to weave Gen 1-3 together with a wide assortment of texts within the general flow of his theological reasoning. On the other hand, Irenaeus' presentation of the Gnostic reading of Gen 1-3 in AH 1 also bears some resemblance to his own intertextual hermeneutical practice, even if the nature of the textual relationships are theologically distinctive. Irenaeus' description of the Gnostic intertextual use of

\footnotetext{
${ }^{9}$ Matthew Steenberg, Irenaeus on Creation (Leiden: Brill, 2008), 4.

${ }^{10}$ Ibid., 1.

${ }^{11}$ Matthew Steenberg, of God and Man (New York, T\&T Clark, 2009), 23.
} 
Gen 1-3 will be framed into four similar procedural methods including: catchwords, gematria, prosopological interpretation, and a "plain sense" reading. Clearly the Gnostic textual networking competes with Irenaeus' intertextual exegesis and his reception of these creation texts. Therefore, as we will argue, an appreciation for the way Irenaeus reads scriptures in harmony will serve to establish a framework for a much more comprehensive understanding of the performance of Gen 1-3 in his polemical theology than any previous study. ${ }^{12}$

\subsection{The Intertextual Nature of Irenaeus' Hermeneutics}

It is reasonably clear that throughout $A H$ Irenaeus' primary purpose is, contra the heretics, to organize systematically the truth of God revealed in both Testaments. ${ }^{13}$ As a result, any discussion of scriptural exegesis in Irenaeus must come to terms with this theological integration of the prophets and the apostles in his thought. This intertextual orientation of Irenaeus' hermeneutical perspective is evident explicitly in the secondary evaluations of the Bishop's exegesis and Irenaeus' own summaries of the exegetical task. It is also implicit in his polemical critique of the Gnostic misappropriation of scripture.

Evaluations of the Irenaeus' hermeneutics have long observed that harmonization is central to his scriptural interpretation. In an important article Denis Farkasfalvy recognizes the continuity between Irenaeus' theology derived from the scriptures and his theology of scripture. ${ }^{14}$ Irenaeus' views on the inspiration of scripture are firmly embedded within the broader framework of revelation. This unifies the Testaments under the provision of one God from who are "all miracles, all divine interventions and all revelations." ${ }^{15}$ The unification of revelation in the ontological nature of God turns Farkasfalvy's eye towards Irenaeus' use of consonare, which he determines to function as a general "technical

\footnotetext{
${ }^{12}$ Steenberg discusses Irenaeus' hermeneutics under three "interpretive backdrops" termed: "discernment of the motivation or reasons behind God's creative act," "the conception of creation ex nihilo," and "the chiliastic vision of the eschaton." While these interpretive backdrops are certainly represented in Irenaeus, fundamentally they all participate in Irenaeus' hermeneutical bent toward scriptural harmony. Steenberg, Irenaeus, 21.

${ }^{13}$ Orbe, Teología V.1, 9.

${ }^{14}$ Denis Farkasfalvy, "Theology of Scripture in Irenaeus," RevBén 68 (1968): 319-33.

${ }^{15}$ Ibid., 321.
} 
term" for the Bishop's exegesis. ${ }^{16}$ Farkasfalvy's keen insight is worth an extended citation:

The history of revelation as understood by Irenaeus, obliges the Christian exegete to move constantly between the two Testaments, clarifying and illustrating the texts by each other. The method of harmonizing is, for Irenaeus a method postulated by the very essence of the Bible as a record of the history of salvation. Harmonization becomes a theological norm for exegesis: an interpretation is proved to be correct if its agreement with other texts can be proved. The word "consonare" used by Irenaeus repeatedly in exegetical context, sounds almost as a technical term of his exegesis. He considers it as the principal result of his explanations that the Scriptures could be proved to be in perfect harmony among themselves: "omnis Scriptura a Deo nobis data consonans (symphonôs) invenietur $(2.28 .3){ }^{17}$

For Farkasfalvy the fundamental feature of Irenaeus' exegesis is harmony (consonans). Scriptural harmony is the "theological norm" and the "principal result" of his exegesis. This harmony, according to Farkasfalvy, is inherent to the history of revelation in scripture as the interconnected trajectory of salvation history under the Trinitarian administration of the Father, Son, and Spirit. ${ }^{18}$ In this respect, scriptural harmony is an extension of his doctrine of revelation evidenced in his doctrine of God and the dispensational connections within the divine economy.

Farkasfalvy points us to the important passage in $A H$ 2.28.3, where the Bishop of Lyon breaks off his extended refutation to summarize some principles of proper scriptural exegesis. ${ }^{19}$ Irenaeus' summary confirms Farkasfalvy's observations:

And all Scripture, which has been given to us by God, shall be found by us consistent; and the parables shall harmonize with those passages which are perfectly plain; and those statements the meaning of which is clear, shall serve to explain the parables; and through the many diversified utterances there shall be heard one

\footnotetext{
${ }^{16} \mathrm{Ibid} ., 328$. See also, Bertrand de Margerie, Introduction à L'historie de L' exégèse: 1 . Les Pères grecs et orientaux (Paris: Les Édition du Cerf, 1980), 69-70. The uses of consonare and its variants include: $A H$ 1.10.2, AH 1.14.2, AH 2.2.3, AH 2.10.1, AH 2.15.2, AH 2.25.2, AH 2.28.3, AH 3.11.8, AH 3.12.11, AH 3.12.12, AH 3.13.3, $A H$ 4.14.2, $A H$ 4.18.4, $A H$ 4.38.3, $A H$ 4.41.4, AH 5.35.1, AH 5.36.3. A family synonyms found throughout Irenaeus' corpus communicates the fundamental unity and coherence of the scriptures including: textum, constans, congruum, coaptare, and disponit. Cf. Reynders, Lexique Comparé de Adversus Haereses de Saint Irénée (Louvian: Peeters, 1963).

${ }^{17}$ Farkasfalvy, "Theology of Scripture," 328. Farkasfalvy omits nobis from his citation of AH 2.28.3.

${ }^{18} \mathrm{He}$ points to $A H$ 4.33.15. Lewis Ayres also raises awareness of a related aspect of this conversation, the need for a robust theology of the soul that unifies scriptural interpretation with Christian formation. See Lewis Ayres, "The soul and the reading of scripture: a note on Henri de Lubac," SJT 61.2 (2008): 173-90.

${ }^{19}$ Mary Ann Donovan, One Right Reading?: A Guide to Irenaeus (Collegeville, MN: Liturgical Press, 1997), 53. Cf. AH 1.10.1, AH 1.22.1.
} 
harmonious melody in us, praising in hymns that God who created all things. ${ }^{20}$

The qualitative descriptions of Irenaeus' exegesis are unmistakable. The proper hermeneutical orientation assumes all scripture is derived from God, who created all things, and by logical extension will be found to be perfectly "consistent" (consonans). Not only this, any obscure passages should be read in harmony (consonabunt) with the more obvious passages in the scriptural witness. ${ }^{21}$ Far from ignoring the diversity of scripture, he acknowledges the diversity of the scriptural witness is precisely the issue at hand. But despite the array of problematic texts and confounding passages, he believes that the scriptures may be harmonized successfully so that they will project with a single voice "one harmonious melody" (unam consonantem melodiam).

In other contexts Irenaeus emphasizes the exegesis of texts within the economic trajectory of salvation history, which he terms the "harmony of salvation" (consonantiam salutis). ${ }^{22}$ Rousseau references this as an allusion to the parable of the Prodigal Son, where the son hears the "music" ( $\sigma u \mu \varphi \omega v i ́ \alpha \varsigma)$ and runs to his father's house. In the same context, he also points to the language of $\varphi \omega v \eta$ where it applies to the Spirit in Rev $1: 15 .^{23}$ The harmony of the music is, for Irenaeus, representative of the harmony of salvation as it unfolds within the divine economy. ${ }^{24}$ The historical acts of God in scripture may be harmonized, as Farkasfalvy notes, precisely because they originate from the God who creates all things with harmony and order..$^{25}$ In $A H 4.20 .7$ he also describes the manifold ways that God in Christ has directed salvation history, such as the various prophecies and theophanies with a succession of rhetorical terms that illustrate the harmonious

\footnotetext{
${ }^{20}$ AH 2.28.3. et omnis Scriptura a Deo nobis data consonans nobis inuenietur, et parabolae his quae manifeste dicta sunt consonabunt, et manifeste dicta absoluent parabolas, et per dictionum multas uoces unam consonantem melodiam in nobis sentiet, laudantem hymnis Deum qui fecit omnia.

${ }^{21} \mathrm{He}$ believes all scripture contains "parables and allegories" (parabolae et allegoriae). AH 1.3.3. See also AH 2.10.1, AH 2.22.1, AH 3.11.8, AH 3.12.12, AH 3.13.3.

${ }^{22}$ AH 4.14.2. Antonio Orbe, Teología de San Ireneo IV: Traducción y comentario del Libro IV del «Adversus haereses» (Madrid: Biblioteca des Autores Cristianos, 1996), 191 n. 23. Behr, Asceticism and Anthropology in Irenaeus and Clement (Oxford: Oxford University Press, 2000), 53.

${ }^{23}$ AH 4.14.2.

${ }^{24}$ Irenaeus refers to the story of the Prodigal Son in AH 3.19.3 and AH 4.36.7.Cf. Philippe Bacq S.J., De l'ancienne à la nouvelle Alliance selon S. Irénée: unite du livre IV del'Adversus Haereses (Paris: Presses Universitaires de Namur, 1978), 117-8.

${ }^{25}$ AH 4.38.3.
} 
nature of all salvific events that are fittingly and properly arranged in and through Christ. ${ }^{26}$

While Behr has observed the theological construct of the divine economy as the necessary prolegomena for Irenaeus' theological framework, it also applies more concretely to Irenaeus' exegesis. ${ }^{27}$ We see the interconnection of Irenaeus' theology and exegesis is also evident in the Epideixis, which offers a summary account of the structure of Christian belief through the "inner connections of the saving truths" embodied in the regula fidei in Epid $6{ }^{28}$ There is a clear methodological concern for the interconnections of scriptures organized by the theological contents of faith summarized in the regula, and, as Hefner observes, the regula functions as a theological framework for Irenaeus. This is most evident in $A H$ 2.27.1 where he argue that ambiguous expressions ought to be interpreted in correspondence with the "body of truth" (veritatis corpus) in order to yield the "similar adaptation of its members" (simili aptatione membrorum) and avoid any "disturbance" (concussione) of its parts. ${ }^{29}$ Irenaeus' perspective of the unity of divine activity throughout both Testaments implies the faithful are "justified to use all current methods (allegory, etymology, grammatical analysis, number symbolism, etc.) in order to discover the mysteries of Christ hidden in the text." In other words, all concurrent methods of interpretation are subservient to the fundamental perspective of the unity and harmony of the scriptures. ${ }^{30}$

In a more recent study, Farkasfalvy points to Irenaeus as the first of the postapostolic age to provide widespread and consistent parallels between the old and New Testaments, which he terms Irenaeus' “canonical principle." ${ }^{11}$ This “canonical principle" reflects a new style of exegesis in Irenaeus that "thrived on the juxtaposition of quotations from various independent texts, demanded verbally

\footnotetext{
${ }^{26}$ Eric Osborn, Irenaeus of Lyon (Cambridge: Cambridge University Press, 2001), 159. Behr, Asceticism, 55-6.

${ }^{27}$ Behr, Asceticism, 34. James G. Bushur, “'Joining the End to the Beginning' Divine Providence and the Interpretation of Scripture in the Teaching of Irenaeus, Bishop of Lyon," unpublished dissertation (University of Durham, 2009), 72 n. 102.

${ }^{28}$ Thomas F Torrance, "Kerygmatic Proclamation of the Gospel: The Demonstration of Apostolic Preaching." in Divine Meaning: Studies in Patristic Hermeneutics, 56-74 (Edinburgh: T.\&T. Clark, 1995), 108; Stephen Presley, "The Rule of Faith and Irenaeus's Demonstration of the order and connection of the scriptures," ORA (2010): 48-66.

${ }^{29}$ AH 2.27.1.

${ }^{30}$ Farkasfalvy, “Theology of Scripture," 327.

${ }^{31}$ Farkasfalvy, Inspiration and Interpretation: A Theological Introduction to Sacred Scripture (Washington D.C.: The Catholic University of America Press, 2010), 92, 114. See also Ivor Davidson, The Birth of the Church: From Jesus to Constantine AD 30-312, vol. 1 (Grand Rapids: Baker Books, 2004).
} 
accurate quotations, carefully caught inexact usage, confronted variant readings, and accused opponents of slight but nefarious alteration of certain key terms." 32 Farkasfalvy also suggests the expansion of this exegetical concern for harmonization is due to the technological development of the codex..$^{33}$ Assembling scripture into codices meant that "scriptural texts became randomly accessible: one was able to page through a whole codex to check the exactness of a quotation, on parallel texts, and on various small details in the wording much more quickly than was possible when the text was on scrolls." ${ }^{34}$ We know from Skeat's analysis that Irenaeus, at the very least, possessed a codex containing the four Gospels, otherwise his discussion of their canonical arrangement in AH 3.11.8 would be unnecessary. No doubt those who came after Irenaeus modified this "new exegetical approach" in the formal scriptural commentaries that developed from the third century, but, as Frances Young confirms, this “"compounding' of texts with other texts seems characteristic of second-century Christian use of the Bible." 35

Like Farkasfalvy, Eric Osborn considers consonare or consonantia a rhetorical term comprising both "logical coherence and aesthetic fitness." ${ }^{36}$ He reminds us of the long history of "fitness" (aptum, $\pi \rho \varepsilon \pi o v)$ in rhetorical traditions and classical culture. He points to the origins of the term in the original Pythagorean sense of harmony, but suggests that in Irenaeus it evolves into a general theological principle of coherence. This principle, for Osborn, navigates between the scriptures and the regula fidei/veritatis, where the regula is fashioned from harmonizing passages..$^{37}$ Jacques Fantino also develops the notion of consonare, but complements his study by pointing us to the related concept of "order" (ordo; ordinatio). He defines this rhetorical concept as an "existing order in a set of realities" and shows it frequently applied to the scriptures and the regula. ${ }^{38}$ Like consonare the term is

\footnotetext{
${ }^{32}$ Ibid., 115.

${ }^{33}$ Ibid., 114-5.

${ }^{34}$ Ibid., 115. See also Harry Gamble, Books and Readers in the Early Church, 49-66. Colin H. Roberts and

T. C. Skeat, The Birth of the Codex (London: Oxford University Press, 1983).

${ }^{35}$ Young, Biblical Exegesis, 133. The relationship between the intertextual networking in Irenaeus and the latter tradition is well beyond the scope of this study. However, given the influences of intertextuality mentioned below, it is evident that this was characteristic of Christian exegesis in the ancient world. Cf. Young, Biblical Exegesis, 119-39. Ayres, Nicea and Its Legacy, 31-40.

${ }^{36}$ Osborn, Irenaeus, 159. Presley, "The Rule of Faith," 63

${ }^{37}$ Ibid., 159.

${ }^{38}$ Jacques Fantino, La theologie d'Irenee. Lecture des Ecritures en reponse a l'exegese gnostique: Une approche trinitaire (Paris: Éditions du Cerf, 1994) 22n31. cf. AH 1.8.1, Epid 6. Orbe also notes the importance of $\tau \alpha \chi \imath$. Cf. Orbe, Teologia IV, 516 n. 25.
} 
ontologically oriented because it assumes "God made all things with measure and order" (omnia enim mensura et ordine Deus facit). ${ }^{39}$ The ordo of scripture adds a temporal or chronological aspect to the nature of scriptural harmony. ${ }^{40}$ Young also highlights Irenaeus' sense of sequence and argues that, while he has a concept of linear history, he consistently locates "anticipations, repetitions, recapitulations, reversals, ups and downs" within the unfolding of the scriptural narrative. ${ }^{41}$ To be sure, Irenaeus consistently summarises the history of salvation with ordered arrangements of echoes and allusions to the events recorded in scripture, but this does not preclude the possibility of theological and hermeneutical links between texts and events.

The studies on the history of interpretation have largely confirmed these views. ${ }^{42}$ Margerie identifies five categories to Irenaeus' exegesis including: 1 ) the rule of truth, 2) tradition, 3) unity and harmony of the scriptures, 4) reading obscure passages in light of clear ones, and 5) appreciation for the transcendence of the divine author. Although, as Farkasfalvy suggests, these rules are more interrelated than Margerie allows, his third rule orients Irenaeus' applied exegesis. ${ }^{43}$ This rule assumes any interpretation is validated by its correspondence and harmony with the rest of scripture. Margerie also confirms Farkasfalvy's study and observes Irenaeus' extensive use of the term consonare in the context of exegetical discussions. Similarly, Henning Reventlow suggests Irenaeus' most significant contribution to the history of biblical interpretation is that "he laid the foundation for the concept of harmony for understanding individual passages of Scripture." ${ }^{44}$ While Norbert Brox and Osborn both affirm the categories of Margerie, they build

\footnotetext{
${ }^{39} \mathrm{Cf}$. AH 4.4.2. Fantino, La Théologie, 23.

${ }^{40}$ James Kugel and Rowan Greer, Early Biblical Interpretation (Philadelphia: Westminister Press, 1986), 176.

${ }^{41}$ Frances Young, The Art of Performance: Towards A Theology of Holy Scripture (London: Darton, Longman and Todd, 1990), 79. Young rightly contrasts the modern conceptions of "biblical theology" as a discipline with Irenaeus' understanding of the continuity of the biblical events. However, her contrast between Irenaeus' concern for the "reality" of Christ over and against the historicity of Christ does not fully appreciate his motivations in coordinating scriptural events within his summaries of salvation history. Ibid., 78-80. See Epid.11-30, AH 2.2.5, AH 3.3.3.

${ }^{42}$ See the studies: Herra, Irénée de Lyon Exégète (Etude Historique: Paris, 1920). M. Jourjon, "Saint Irénèe lit la Bible," in Le monde grec ancien et la Bible, 153-70 (Paris: Beauchesne, 1984). De Andia, “Irénèe théologien de l' unité," NRT 109 (1987): 31-48. De Andia, “Modéles de l' unité des testaments Semon Irénée de Lyon. StuPat 21 (1989). Simonetti, “Per Typical as vera: Note sull' esegesi di Ireneo, VetChr 18 (1981): 357-82.

${ }^{43}$ Margerie, introduction, 69.

${ }^{44}$ Henning Graf Reventlow, History of Biblical Interpretation: Vol 1: From the Old Testament to Origen (Atlanta, Society of Biblical Literature, 2009), 173. Originally published: Epochen der Bibelauslegung Band 1: Vom Alten Testament bis Origenes (Müchen, Verlag C.H. Beck, 1990).
} 
upon his work with more detailed examples and few additional categories. ${ }^{45}$ Grant and Tracy simplify the categories of Irenaeus' exegesis, highlighting only two methods drawn from his critique of the Gnostic exegesis in AH 1.8.1-1.9.5. The Gnostics, according to Irenaeus, disregard the order and the context of the passages and interpret the clear and obvious by means of the dark and obscure. ${ }^{46}$

While many secondary studies recognize the importance of scriptural harmony in Irenaeus, we find the same emphasis throughout Irenaeus' own descriptions of the exegetical task. In addition to $A H$ 2.28.3 and AH 2.27.1 mentioned above, in AH 3.12.9 Irenaeus reports that all Paul's epistles are "consonant" (consonant) with his declaration that there is one God who created all things (Acts 14:15-17). In rhetorical fashion he follows his commentary on Paul with a description of his argumentation and method of exegesis saying, "proofs in the Scriptures cannot be proven except from the Scriptures themselves" (ostensiones quae sunt in Scripturis non possunt ostendi nisi ex ipsis Scripturis). ${ }^{47}$ In other words, the interpretation of scripture necessitates scripture. Irenaeus has already informed the reader that in $A H 3$ he will confront his opponents with proofs from the scriptures, but here we see that these proofs are intentionally interrelated. ${ }^{48}$ These proofs from the scriptures yield lengthy arguments that condense the manifold witness of the scriptures. Therefore, Irenaeus' intertextual argumentation frequently weaves texts into a complex set of intertextual networks. The location of this statement at the onset of Irenaeus' opening exegetical arguments in AH 3 also points to the importance of this textual networking for Irenaeus' own theological argumentation in $A H$ 3-5.

In another instance he draws on Paul's imagery of the body in Eph 4:16/Col 2:19 to argue the creation of all things by means of the Word as the "head" (caput) that orders the rest of the body. Only when an interpreter grasps this theological "head" will the remaining part of the body of scripture be properly fitted together. Those who confess the true Creator will find themselves reading scripture in

\footnotetext{
${ }^{45}$ Norbert Brox, "Irenaeus and the Bible," in Handbook of Patristic Exegesis, vol 1, ed. Charles Kannengiesser (Brill, Leiden, 2004): 483-506.

${ }^{46}$ Robert Grant and David Tracy, A Short History of the Interpretation of the Bible (Philadelphia: Fortress Press, 1984), 49-50.

${ }^{47} \mathrm{AH}$ 3.12.9. For a discussion of an epideixis as a deductive proof by means of syllogism see Scott D. Mangeillo, "Irenaeus Rhetor," unpublished Dissertation (University of Notre Dame, 2008), 7-15. See also R. Dean Anderson Jr, Ancient Rhetorical Theory and Paul (Leuven: Kok Pharos, 1996).

${ }^{48}$ AH 3.pf.1.

${ }^{49}$ AH 4.32.1.
} 
continuity with the apostolic teachings and, as a result, every word of scripture will appear "consistent" (constabit). So creation by means of the Word is a hermeneutical key that unlocks the door to unity of salvation history and the continuity of scripture. Elsewhere he speaks of the consonantia of the four Gospels, the unity and harmony of the covenants, the harmony of Paul and Luke, and the harmony between scripture and tradition. ${ }^{50}$ These references to the intertextual nature of the exegetical task pervade his argument and encapsulate his exegetical perspective. Irenaeus' intertextual perspective also surfaces indirectly in the polemical characterizations of his opponent's exegesis. Fundamentally he argues the Valentinians "disregard the order and the connection of the Scriptures" (ordinem quidem et textum Scripturarum supergredientes). ${ }^{51}$ This criticism implies that Irenaeus' irritation with Gnostic use of scripture is not necessarily the meaning of textsalthough that is surely a consequence of their procedures-but the way the Gnostics order and connect the scriptural material, especially with their own non-canonical traditions. ${ }^{52}$ The allegorical interpretation in Valentinus, for example, blurs the line between text and commentary, where interpretation takes the form of a "new composition." ${ }^{53}$ Valentinus' reading of scripture (and Gen 1-3 in particular) purges the texts of any concept of temporality and alters the metaphors and characters in the opening drama in order to produce an original narrative. ${ }^{54}$ Valentinus' interest in an epistemological approach to salvation, according to J. Williams, determined a variety of "exegetical changes," or careful alterations to the texts of scripture, in order to convey his theological perspective..$^{55}$ Similarly, Behr describes how they purpose to isolate truths from various sources and "redeploy them in new myths."56 He recognizes that the Gnostic interpreters reject any attempt to understand Christ "according the Scriptures." ${ }^{57}$ While Michael Williams has challenged the categorical

\footnotetext{
${ }^{50}$ AH 3.11.8, AH 3.12.12, AH 3.13.3, AH 4.32.1.

${ }^{51} A H$ 1.8.1. See also $A H$ 1.9.4.

${ }^{52}$ Kurt Rudolph, "Bibel und Gnosis zum Verständnis Jüdisch-Biblischer Texte in Der Gnostischen Literatur, vornehmlich aus Nag Hammadi," in Gnosis Und Spätantike Religionsgeschichte: Gesammelte Aufsätze, 190-209 (Leiden: Brill, 1996), 208-9.

${ }^{53}$ David Dawson, Allegorical Readers and Cultural Revision in Ancient Alexandria (Berkeley: University of California Press, 1992), 129.

${ }^{54}$ Ibid., 133.

${ }^{55}$ Jacqueline Williams, Biblical Interpretation in the Gnostic Gospel of Truth From Hag Hammadi (Atlanta: Scholars Press, 1988), 190.

${ }^{56}$ Behr, The Way to Nicaea (New York: St. Vladimir's Seminary Press, 2001), 21.

${ }^{57}$ Ibid., 22-3.
} 
descriptions and regularity of this type of "inverse exegesis," even he acknowledges the examples are widespread. ${ }^{58}$

As a result, Irenaeus frequently uses polemical imagery to disparage Gnostic exegesis. ${ }^{59}$ In each instance he speaks of the Gnostic adaptation of the elements of scripture with other Gnostic sources. In $A H$ 1.3.6, for example, Irenaeus describes how the Gnostics "strive to adapt the good words [of scripture] to their own wicked inventions" (adaptare cupientes ea quae bene dicta sunt his quae male adinuenta sunt ab ipsis). ${ }^{60}$ Then, in AH 1.8-9 Irenaeus uses series of images to illustrate the Gnostic misappropriation of scripture. He compares their textual networking to braiding a rope of sand or weaving a patchwork of fables. ${ }^{61}$ His most famous critique of Gnostic exegesis is a well-known example of the mosaic of the king in AH 1.8.1 and the Homeric cento in AH 1.9.4. Comparing scripture passages to tiles on a mosaic representing a king, Irenaeus describes how the Gnostic exegetes "transfer" (transfero) passages and rearrange them to form the image of a fox or $\mathrm{dog}$. ${ }^{62}$ The only fitting solution for Irenaeus is to return the tiles to their proper arrangement. Similarly, he cites a collection of Homeric verses arranged in a cento extracted from both the Iliad and the Odyssey. Just as this cento comprises an assortment of Homeric verses arranged to tell a different story, the Gnostics remove names and sayings of scripture and adapt them to their own narratives..$^{63}$ The faithful interpreter will, according to Irenaeus, recognize the verses but not the themes of the storyline. Only when the verses are returned to their proper order will the reader observe the true story. ${ }^{64}$ Likewise only when the scriptures are framed within their proper order and connection and fitted to the "body of truth" (veritatis corpusculo) will the true meaning avail itself.

\footnotetext{
${ }^{58}$ Michael Allen Williams, Rethinking “Gnosticism”: An argument for Dismantling a Dubious Category (Princeton: Princeton University Press, 1996), 56, 77; Steenberg, Irenaeus, 27.

${ }^{59} \mathrm{AH}$ 1.pr.1, AH 1.3.6, AH 1.8.1 and AH 1.9.4. See also: D. Jeffrey Bingham, Irenaeus' use of Matthew's Gospel in Adversus Haereses (Louvain: Peeters, 1998), 16-18. Behr, The Way to Nicaea, 20.

${ }^{60} \mathrm{AH}$ 1.3.6. For examples see: G. P. Luttikhuizen, Gnostic Revisions of Genesis Stories and Early Jesus Traditions (Leiden: Brill, 2006).

${ }^{61}$ AH 1.8.1.

${ }^{62} \mathrm{AH}$ 1.8.1.

${ }^{63}$ In his article "Homeric Cento in Irenaeus," Robert Wilken corrects Daniélou who argued that Valentinus composed this cento. Wilken shows it to be a distinctive literary devise in the classical world, but concludes that Irenaeus probably does not like the cento, even though he uses it as an illustration.

${ }^{64}$ AH 1.9.4.
} 
In another instance, Irenaeus compares the isolated Valentinian interpretation of 1 Cor 15:50 to an amateur wrestler who latches onto one part (unam partem) of his opponent's body with a single move. ${ }^{65}$ Through a combination of moves, his opponent has no trouble pinning the unskilled wrestler to the ground. Not to be outdone, the conquered wrestler foolishly continues to grasp the one part of his opponent and ludicrously tries to claim victory. In the same way, the Valentinians latch on to one verse (1 Cor 15:50) to support their dualistic thought and, neglecting the actual force of terms, prefer to interpret it in isolation (ipsas, novov) from the rest of the Pauline corpus and salvation history. ${ }^{66}$ Given that texts are inherently theologically interconnected, reasons Irenaeus, by neglecting the true understanding of one passage (1 Cor 15:50) they misunderstand a multitude of others. ${ }^{67}$ Throughout his work and through a variety of illustrations, the Bishop of Lyon returns to this same basic critique of the Gnostic division, separation, and isolation of scripture. ${ }^{68}$

Therefore, given Irenaeus' supreme concern for the proper integration of scriptural revelation, any inquiry into Irenaeus' reading of scripture, if it is to be sensitive to Irenaeus' own hermeneutic, must account for the harmonious interpretative relationship of scripture in his thought and argumentation. Interestingly, Gerard Luttikhuizen makes the same observation from his evaluation of Gnostic readings of Genesis. Citing the contribution of Grivel, he writes: "Reading is an act of 'intertextualization,' because during the reading process, the reader's knowledge of other oral and written texts is constantly activated. If we want to know how a given Gnostic text is understood by ancient or modern readers, we should therefore try to find out what are the texts in the light of which it is read." Like Luttikhuizen, we recognize that the appropriate way to understand Irenaeus' reading of scripture is to identify the intertexts he reads alongside any given text and determine how he utilizes a variety of intertextual interpretive strategies to arrange these textual relationships. In this study we are concerned with precisely this web of Irenaean textual relationships or, in the words of John Lawson, the

\footnotetext{
${ }^{65}$ AH 5.13.2. cf. AH 5.14.4.

${ }^{66}$ AH 5.13.2; Orbe, Teología V.1, 618-9.

${ }^{67}$ AH 5.13.5.

${ }^{68}$ AH 4.pf.4; AH 5.20.1-2.

${ }^{69}$ Luttikhuizen, Gnostic Revisions, 162. See also: C Grivel, “Thèses préparatoires sur les intertexts," in R. Lachmann, Dialogizität, Theorie und Geschichte der Literatur und der schönen Künste, 237-48 (Munich: Fink, 1982).
} 
"mosaic of Biblical quotations."70 This study on Irenaeus' intertextual networking, however, was also influenced by the discussions of "intertextuality" in modern Biblical scholarship that raised our awareness to the practice of intertextuality in the ancient world. ${ }^{71}$

\subsection{Intertextuality in Modern Biblical Studies and the Ancient World}

Within contemporary Biblical Studies the expanding interest in "intertextuality" has generated a variety of definitions and methodologies. ${ }^{72}$ Julia Kristeva, building upon the work of Mikhail Bakhtin, first introduced the term in 1966, with the description that "any text is constructed as a mosaic of quotations; any text is the absorption and transformation of another." ${ }^{73}$ Poststructuralist theorists lauded her literary studies and the term "intertextuality" was met with instant approval. But since this initial coinage, the term intertextuality has assumed a variety of definitions. Naturally poststructuralists tend to withhold concerns about authorial intent and historical priority, which are essential to understanding hermeneutics in the ancient world. ${ }^{74}$ Given this ambiguity, some biblical scholars have even suggested dropping the use of the term altogether. ${ }^{75}$

But despite its detractors clearly "intertextuality is an inescapable aspect of biblical studies." ${ }^{176}$ The method of intertextual study, as Stefan Alkier defines it, assumes the task of "investigating the relationships that a text can have with other

\footnotetext{
${ }^{70}$ Lawson, The Biblical Theology, 23.

${ }^{71}$ I am persuaded to use the language of "inter-scriptural" instead of "intertextual" because I feel that it more appropriately describes Irenaeus' hermeneutical perspective. But due to the prevalence of "intertextual" and "intertextuality" we continue to use these terms. Nevertheless, the language "interscriptural" highlights Irenaeus' self-understanding as a Christian that principally motivates his scriptural networking.

${ }^{72}$ For a summary of these approaches see: Stephen Moyise, "Intertextuality and the Study of the Old Testament in the New Testament," in Old Testament in the New Testament: Essays in Honour of J. L. North ed. Stephen Moyise JSNTSup 189 (Sheffield: Sheffield Academic Press, 2000), 14-41; Michael R. Stead, The Intertextuality of Zechariah 1-8 (New York: T\&T Clark, 2009), 19-27; Stefan Alkier, "Intertextuality and the Semiotics of Biblical Texts," in Reading the Bible Intertextuality, eds. Richard B. Hays, Stefan Alkier, and Leroy A. Huizenga, 1-21 (Waco, TX: Baylor University Press, 2009), and Alkier, "New Testament Studies on the Basis of Categorical Semiotics," eds. Richard B. Hays, Stefan Alkier, and Leroy A. Huizenga, 223-248 (Waco, TX: Baylor University Press, 2009).

${ }^{73}$ Julia Kristeva, Desire in Language: A Semiotic Approach to Literature and Art (New York: Columbia University Press, 1980), 66.

${ }^{74}$ Kristieva now prefers the term "transposition" in order to communicate more clearly the "passages of one signifying system into another." Kristieva, Revolution in Poetic Language (Paris, Éditions du seuil, 1974). See also: Julia Kristeva and T. Moi, The Kristeva Reader (Oxford: Blackwell, 1986), 59-60.

${ }^{75}$ William Irwin, “Against Intertextuality," PL 28 (2004): 227-42.

${ }^{76}$ Alkier, "Intertextuality," 7.
} 
texts." ${ }^{77}$ He discusses the methodological implications for biblical studies by distinguishing between "Intratextuality," "Intertextuality," and "Extratextuality." "Intratextuality" explores an isolated text within the application of literary criticism, "Intertextuality" examines the meanings emerging from related texts, and "Extratextuality" isolates the effect of meaning located in references to extratextual material. ${ }^{78}$ In this present study we are concerned with a particular nature of intertextual investigation that Alkier terms a "reception-oriented perspective," which aims at investigating sets of historically verifiable texts. ${ }^{79}$ As we have argued, however, the practice of textual harmonization is not purely a modern development of literary criticism, but explicit in Irenaeus' own summaries of the exegetical task and applied exegesis.

Additionally, Irenaeus' interest in textual relationships is representative of a broader concern for textual harmony in the ancient world. The interest of textual relationships in Biblical Studies has isolated elements of intertextuality in Jewish, Christian, and Hellenistic studies. ${ }^{80}$ Michael Fishbane's landmark work, Biblical Interpretation in Ancient Israel, employs the term "Inner-Biblical Exegesis" and demonstrates how the Hebrew Bible is not merely the object of exegetical analysis, but also an exegetical work in its own right. ${ }^{81}$ Fishbane's point is that the Hebrew Bible was not transmitted in pristine form, but "subject to redaction, elucidation, reformation, and outright transformation." ${ }^{82}$ The received texts (traditum) were blended with other traditions (traditio) through the process of transmission to form what we now have in the Jewish Scriptures. Fishbane's work reveals the importance of textual interdependence and interrelationships in Hebraic culture and exegesis.

\footnotetext{
${ }^{77}$ Ibid., 3.

${ }^{78}$ Ibid., 8-9. He further qualifies intertextuality investigation with three perspectives: "a productionoriented perspective, a reception-oriented perspective, and an experimental perspective." Ibid, 9. In a similar framework Steve Moyise identified "intertextuality" as an umbrella concept comprising at least three approaches including: "Intertextual Echo," "Dialogical Intertextuality" and "Postmodern Intertextuality." Moyise "Intertextuality" 17-8. See also: Porter, "The Use of the Old Testament in the New Testament: A Brief Comment on Method and Terminology," in Early Christian interpretation of the scriptures of Israel: investigations and proposals, Craig A. Evans, James A. Sanders (Continuum, 1997). T. K. Beal, "Intertextuality," in Handbook of Postmodern Biblical Interpretation, ed. A. K. A. Adam (St Louis: Chalice, 2000), 129. T.R. Hatina, "Intertextuality and Historical Criticism in New Testament Studies: Is there a Relationship?," BibInt 7 (1999): 28-43.

${ }^{79}$ Alkier, "Intertextuality," 9-10.

${ }^{80}$ Bingham, Irenaeus' use of Matthew's Gospel, 301-02. See also: Elizabeth A. Clark, Reading Renunciation: Asceticism and Scripture in Early Christianity (Princeton: Princeton University Press, 1999), 63-69, 12228.

${ }^{81}$ Michael Fishbane, Biblical Interpretation in Ancient Israel (Oxford: Clarendon Press, 1985).

${ }^{82}$ Ibid., 542-3.
} 
Similarly, Daniel Boyarin provided another work on rabbinic midrash entitled the Intertextual Hermeneutic and the Dialogical Nature of Midrash. Boyarin's study examines the inherent "intertextual" nature of rabbinic midrash, which "builds its discourse out of textual fragments as a biblical mosaic." ${ }^{83}$ Boyarin's use of "intertextual" assumes at least three aspects: the text is always made up of a mosaic of conscious and unconscious citation of earlier discourse; texts may be dialogical in nature; and there are "culture codes" which influence the construction of new texts in a given culture. While Boyarin is not the first to use the language of "intertextuality" to describe midrash, he is the first to use this theory to examine particular sets of midrash. $^{84}$

Similarly, Richard Hays advances the notion of intertextuality in New Testament Studies with his work on Echoes of Scripture in the Letters of Paul. ${ }^{85} \mathrm{He}$ defines intertextuality as "the imbedding of fragments of an earlier text within a later one" and describes how this has always been a practice inherent to cultural traditions. ${ }^{86}$ Hays defines his intertextual approach as "reading the letters [of Paul] as literary texts shaped by complex intertextual relations with Scripture." ${ }^{87}$ Like Fishbane and Boyarin, Hays describes how the concept of intertextuality is a cultural practice where a text receives an older text to meet new contexts. ${ }^{88}$ Hays' key term, the scriptural "echo," is synonymous with "intertextuality" and often conflated as "intertextual echo." 89

Finally, Frances Young in her work on patristic exegesis describes how the concept of intertextuality characterizes the complexity of early Christian exegesis

\footnotetext{
${ }^{83}$ Daniel Boyarin, Intertextuality and the Reading of Midrash (Bloomington, IN, Indiana University Press: 1990).

${ }^{84}$ Other discussions of intertextuality and midrash include: $\mathrm{S}$. Handelman, The SlAyres of Moses: The Emergence of Rabbinic Interpretation in Modern Literary Theory (Albany: SUNY Press, 1982), J. Faur, Golden Gloves with Silver Dots: Semiotics and Textuality in Rabbinic Tradition (Bloomington: Indiana University Press, 1986).

${ }^{85}$ Richard Hays, Echoes of Scripture in the Letters of Paul (New Haven, CT: Yale University Press, 1989); John Hollander, The Figure of Echo: A Mode of Allusion in Milton and After (Berkeley: University of California Press, 1981).

${ }^{86}$ Ibid., 14.

${ }^{87}$ Ibid., xi.

${ }^{88}$ Richard Hays, "Die Befreiung Israels im lukanischen Doppelwerk: Intertextuelle Narration als kulturkritische Praxis," in Die Bibel im Dialog der Schriften: Konzepte intertextueller Bibellektüre, 117-136 (Tübingen: A. Francke, 2005), 118.

${ }^{89} \mathrm{Cf}$. Hays, Echoes, xi-xii. For conceptual and categorical connections between apostolic exegesis and Jewish exegesis see R. Longenecker, Biblical Exegesis in the Apostolic Period (Grand Rapids: Eerdmans, 1999).
} 
in the post-apostolic age. ${ }^{90}$ According to Young, "Discerning cross-references was taken up with great enthusiasm in the second century." ${ }^{11}$ From the second century onwards both the Old Testament and the New Testament texts are received together in a complex web of intertextual relationships that extends apostolic exegesis. She locates the practice of intertextual readings in the classical and rhetorical education saying, "The fact that education was premised on the imitation of classics meant that intertextuality was an important feature of ancient literary culture. Allusions and quotations laced the correspondence of the literary elite, as well as public discourse." ${ }^{92}$ The blending and assembling of texts was an essential part of classical education and a key aspect of rhetorical discourse. The Fathers of the church, who were schooled in this classical education, clearly emulated these practices. In an earlier work, she also spoke of the philological technique of "cross-referencing" in the Fathers and the fact that early Christian theological disputes were often located in the disagreements over what constitutes an appropriate cross-reference. ${ }^{93}$ Clark also supports Young's conclusions. She remarks that “'intertextual exegesis' is one of the most frequently employed modes of interpretation found in patristic literature." $^{94}$

There is also little doubt that Irenaeus' learned some methods of textual correspondence from his Greek education and studies in the art of rhetoric..$^{95}$ Robert Grant argues that Irenaeus Christianizes at least three key rhetorical terms: hypothesis, oikonomia, and anakephalaiosis that serve as "structural beams" in his theological framework. ${ }^{96}$ According to Grant these rhetorical concepts reflect the "method of correlation" Irenaeus used to relate the concepts and ideas of the various authorities in the tradition. These terms, primarily Pauline in nature, are derived from grammar and rhetoric and developed from their context within the New Testament. Similarly, in another recent study on Irenaeus' rhetorical argumentation, Scott Moringiello argues for appreciation of Irenaeus as a rhetorical theologian. He reads the structure of $A H$ in light of the five moments of classical

\footnotetext{
${ }^{90}$ Frances Young, Biblical Exegesis and the Formation of Christian Culture (New York: Cambridge University Press, 1997).

${ }^{91}$ Young, Biblical Exegesis, 133.

${ }^{92}$ Ibid., 97.

${ }^{93}$ Young, The Art of Performance, 125.

${ }^{94}$ Clark, Reading, 122.

${ }^{95}$ Grant, Irenaeus, 46-53.

${ }^{96}$ Ibid., 53. W. R. Schoedel, "Philosophy and Rhetoric in the Adversus Haereses of Irenaeus," VC 12 (1959): 22-32.
} 
forensic speech including: prooemium, narratio (AH 1-2), probatio (AH 3), refutatio (AH 4), and recapitulatio (AH 5).$^{97}$ Although others have shown Irenaeus to be dependent upon rhetorical traditions, Moringiello shows more comprehensively that the arrangement of Irenaeus' refutation follows the classical rhetorical structure.

As the Bishop of Lyon in the latter part of the second century, Irenaeus stands solidly amid this confluence of intertextual pressures. ${ }^{98}$ It is almost certain that he spent time with Justin in Rome, whose Hellenistic training is widely recognized. ${ }^{99}$ He wrote in Greek and came to Lyon by way of Asia Minor, where he had known Polycarp. ${ }^{100}$ While his entire work is set against the philosophical speculation of the Gnostics, he also mentions interactions with Jews, and notes a number of Hellenistic writers. ${ }^{101}$ Behr, citing the work of Fishbane, Hays and Young, among others, notes the "interconnected relationships" between Moses, Christ, the scriptures and the Gospel implicit in the New Testament writings themselves. From this evaluation he concludes: "This coherence of Scripture, the scriptural texture of the apostolic preaching of the Gospel in his interpretative engagement with Scripture, is the basis for Irenaeus' appeal to canon and tradition, and the full use of the apostolic writings as themselves Scriptures, in his work Against the Heresies."102

Irenaeus is, of course, above all a churchman and concerned with reading the scriptures in continuity with the apostolic teaching. As we have shown, his broader doctrine of revelation, which is often expressed in the framework of the regula, controls his textual networking. Irenaeus believed in the Spirit's role in interpretation, but he was much more concerned with the apostolic testimony in the process of interpretation. Yet despite these streams of intertextual discussions and Irenaeus exegetical orientation, no study has accentuated Irenaeus' intertextual networking in consideration of his applied exegesis, and sought to explain in

\footnotetext{
${ }^{97}$ Moringiello, Irenaeus Rhetor, 7-15.

${ }^{98}$ Although the precise dates of his life remain disputed, most scholars agree he was born roughly between 130-40 C.E. and died around 201-02 C.E. Eric Osborn, Irenaeus of Lyon (Cambridge: University Press, 2001), 2. Grant, Irenaeus, 2.

${ }^{99}$ M. Slusser, "How much did Irenaeus learn from Justin?," StuPat, eds. F. Young, et al (Peeters: Leuven, 2006).

${ }^{100}$ Eusebius, EH V.5.8.

${ }^{101}$ Numerous studies have evaluated the general Gnostic and Jewish influences upon his creation theology, as well as his indebtedness to Justin and Theophilus. See Steenberg, Irenaeus on Creation, 1120.

${ }^{102}$ Behr, The Way to Nicaea, 26, 30. Behr also remarked a few lines earlier: "the coherence of Scripture -the Law, the Psalms and the Prophets- in the apostolic preaching of Christ is shown most clearly in... The Demonstration of the Apostolic Preaching." Ibid., 29.
} 
analytical terms the nature of his intertextual interpretation of scripture. As we will show in the next section, the history of Irenaean scholarship has neglected the importance intertextuality in their analysis of his reading of scripture.

\subsection{Toward an Intertextual Appreciation for Genesis 1-3 in Irenaeus}

\subsubsection{Introduction}

While references to Irenaeus are scattered throughout the Christian tradition, the strongly critical appraisals of Irenaeus surfaced in the nineteenth century. ${ }^{103}$ Scholars frequently characterized his thought as confused and incoherent. ${ }^{104}$ Johannes Quasten sums up this thinking by stating that Irenaeus' work “suffers from any clear arrangement or unity of thought." ${ }^{105}$ This perspective was challenged by the biblical theology movement in the mid-twentieth century that sought to move the discussion from the realm of socio-cultural influences to the analysis of Irenaeus' use of the biblical text itself. ${ }^{106}$ By the late 1960's, following this move toward the biblical text there is a noticeable trend in the positive appraisal of Irenaeus' exegesis, beginning with Peretto's analysis of Irenaeus' reading of Rom 1-8 and Orbe's work on Irenaeus' reading of the Gospel parables. ${ }^{107}$ Twenty-five years later Orbe was still advancing the thesis that a closer evaluation of the Irenaeus' exegesis is an important avenue into the Bishop's thought. ${ }^{108}$ The interest in Irenaeus' reading of particular portions of scripture has continued through the present day, branching into a myriad of studies on Irenaeus' reading of individual books and passages. ${ }^{109}$

\footnotetext{
${ }^{103}$ For a summary that is now dated but still helpful see: Mary Ann Donovan, "Irenaeus in Recent Scholarship," SecCen 4.4 (1984). For a brief discussion of the reception of Irenaeus in the tradition prior to the eighteenth century see Steenberg, of God and Man, 18-9.

${ }^{104}$ Orbe, Teología V.1, 5. Steenberg, Irenaeus, 3-4.

${ }^{105}$ Johannes Quasten, Patrology (Allen, Texas: Christian Classics, 1983), 289. See also Donovan, "Irenaeus," 222. Some of these studies include: Bousset, Jüdisch-christlicher Schuldetrieb in Alexandria und Rom: Literarische Untersuchungen zu Philo und Clemens von Alexandria, Justin, und Irenäus (Göttingen, 1915) and Friedrich Loofs, Theophilus von Antiochien adversus Marcionem und die anderen theologischen Quellen bei Irenaeus (Lepzig, 1930).

${ }^{106}$ Wingren, Man and the Incarnation, 104.

${ }^{107}$ Elio Pretto, "Il pensiero di S. Ireneo su Rom 1:20," RBibIt 8 (1960): 304-23. Pretto, La Lettera ai Romani. Orbe, Parabolas.

${ }^{108}$ Orbe, Teología V.1, 15-16.

${ }^{109}$ For more general studies on the performance of scripture in Irenaeus see: J Hoh, Die Lehre des hl. Ireäus über das Neue Testament (Münster: Verlag der Aschendorffschen Verlagsbuchhandlung, 1919). H. von Campenhausen, “Irenäus und das Neue Testament," TLZ 90 (1965): 1-8.
} 
The discussion of Pauline elements in Irenaeus' thought is a well-worn path. Older studies that question the integrity of Irenaeus' use of Paul include Werner (1889) and Aleith (1937). ${ }^{110}$ Recent studies paint a more positive portrait of Irenaeus' use of Pauline literature, including Bentivegna (1968), Coolidge (1975), McHugh (1982), Norris (1990), Balás (1992), Olsen (1992), Ruiz (1992) and Tosaus Abadía (1995), Bingham (2005, 2012), Graham (2005), and Blackwell (2011). ${ }^{111}$ The definitive study is the work of Rolf Noormann, Irenäus als Paulusinterpret, who with a comprehensive precision isolates and evaluates the nature of Irenaeus' allusions and citations of Paul in AH 1-5. Noormann is more sympathetic to the nuances of Irenaeus' argumentation and his use of the Pauline material. He provides a strong critique of Werner and concludes that Irenaeus is a rather faithful interpreter of Paul. $^{112}$

Studies on Irenaeus' use of the synoptic Gospels have also been a significant point of focus, especially given that Irenaeus is the first to mention the four-fold Gospel canon. ${ }^{113}$ As mentioned above, Orbe and Bacq produced several studies on the Gospel parables and Jesus sayings, while studies on particular Matthean and Lukan texts include: Houssiau (1953), Luckhart (1953), Siniscalco (1967), Czesz

\footnotetext{
${ }^{110}$ Johannes Werner, Der Paulinismus des Irenaeus (Leipzig, 1889). Eva Aleith, "Paulusverständnis in der alten Kirche," ZNT (1937): 70-81.

${ }^{111}$ J. Bentivegna, "Pauline Elements in the Anthropology of St. Irenaeus," StuEvan 5 (1968): 229-33; J. S. Coolidge, The Pauline basis of the concept of Scriptural form in Irenaeus, The Center for Hermeneutical Studies in Hellenistic and Modern Culture, Berkeley, California, Protocol of the eighth colloquy, 4 November 1973 (Berkeley, CA: The Center for Hermeneutical Studies, 1975); J. McHugh, "A Reconsideration of Ephesians 1,10b in Light of Irenaeus," in Paul and Paulinism: Essays in Honour of C.K. Barrett, ed. M.D. Hooker and S.G. Wilson, 302-9 (London: S. P. C. K., 1982); R. A. Norris, "Irenaeus' use of Paul in his polemic against the Gnostics," in Paul and the legacies of Paul, ed. W.S. Babcok, 79-98 (Dallas: SMU Press, 1990); David L. Balas, "The Use and Interpretation of Paul in Irenaeus' Five Books Adversus Haereses," SecCen, 9 (1992); M. J. Olsen, Irenaeus, the Valentinian Gnostics and the Kingdom of God (A.H. Book V): The Debate About 1 Corinthians 15:50 (New York: Mellen Biblical Press, 1992); G. Ruiz, “"Ma puissance se déploie dans la faiblesse' (2 Cor 12:9): An Interprétation d'Irénée de Lyon," in Recherches et tradition: Mélanges patristiques offerts à Henri Crouzel, S. J. sous la direction d'A. Dupleix, 259-69 (Paris: Neauchesne, 1992); J. P. Tosaus Abadía, Cristo y el universo: Estudio linguístico y themático de Ef 1:10h en Efesios y en la obra de Ireneo de Lyon, (Salamanca: Universidad Pontificia, 1995); D. J. Bingham, "Irenaeus reads Romans 8: Ressurection and Renovation," in Early Patristic Readings of Romans, eds Kathy L. Gaca and L. L. Welborn, 114-32 (New York: T\&T Clark, 2005); Susan L. Graham, "Irenaeus as Reader of Romans 9-11," in Early Patristic Readings of Romans, eds Kathy L. Gaca and L. L. Welborn, 87113 (New York: T\&T Clark, 2005); Benjamin Blackwell, "Paul and Irenaeus," in Paul and the Second Century: The Legacy of Paul's life, Letters, and Teaching, ed. Michael F. Bird and Joseph R. Dodson, 190-206 (London: T\&T Clark, 2011); Bingham, "Irenaeus and Hebrews," in Christology and Hermeneutics of Hebrews: Profiles from the History of Interpretation, eds by Jon C. Laansma and Daniel J. Treier (New York: Continuum, forthcoming).

${ }^{112}$ Rolf Noormann, Irenäus als Paulsinterpret (J. C. B. Mohr: Tübingen, 1994), 1.

${ }^{113}$ There are also a number of studies on the four-fold gospel canon including: T. C. Skeat, "Irenaeus and the Four-Gospel canon," NovT 34 (1992): 194-99; R. Robert, "Le témoignage d'Irénée sur la formation des évangiles," RThom 87.2 (1987): 243-59.
} 
(1977), Andia (1984) Bellinzoni (1992, 1998), and Stanton (2003) with many additional studies on the significance of particular events in the life of Christ. ${ }^{114}$ The most comprehensive is D. J. Bingham's (1998) publication Irenaeus' use of Matthew's Gospel in Adversus Haereses. Bingham's volume is a careful reading of Irenaeus' use of Matthew, and though intertextuality is not an explicit aspect of his method, he recognizes the importance of textual harmony for Irenaeus' hermeneutic.

In addition to the synoptic Gospels, there has been discussion over the influence of Johannine thought upon Irenaeus including: Ferlay (1984) and Poffet (1990), and more recently Hill (2004). ${ }^{115}$ Most recently B. Mutschler published Irenäus als johanneischer Theologe, which was followed two years later by a second monograph entitled Das Corpus Johnneum bei Irenäus von Lyon. ${ }^{116}$ The later volume is a systematic treatment of the use of John's Gospel in the third Book of AH, while the earlier work is a synthesis of the Johannine influence upon Irenaeus. By his own admission he follows the methodology of Noormann, and, in doing so, Mutschler concludes that Irenaeus is the primary Johannine theologian until Origen. ${ }^{117}$

However, this tradition of scholarship, despite recovering an appreciation for Irenaeus as exegete, methodologically abstracted individual texts and pericopes from the structure of Irenaeus argumentation and systematically disconnects the textual networks Irenaeus intentionally fashioned. They have, consciously or unconsciously, disregarded Irenaeus' own hermeneutical perspective and the intertextual nature of his applied exegesis. Within these studies, any discussion of the interrelation of texts is purely coincidental because focusing upon these relationships is not essential to their methodology. For example, more than one

\footnotetext{
${ }^{114}$ A. Houssiau, "L'exégèse de Mt 11:27b selon S. Irénée," ETL 29 (1953): 328-54; R. Luckhart, "Matthew 11,27 in the 'Contra Haereses' of Saint Irenaeus," RUO 23 (1953): 65-79; M. Siniscalco, "La parabola del figlio prodigo (Lc 15:11-32) in Ireneo," SMSR 38.2 (1967): 5326-53; B. Czesz, "La parabola del figlio prodigo (Lc 15, 11-32) in Ireneo," AugR 17 (1977): 107-11; Y. de Andia, "L'interprétation irénéenne de la beatitude des doux: 'Bienheureux les doux, ils recevront la terre en héritage' (Mt 5:5)," StuPat 18.3 (1989): 85-102, originally published "La beatitudine dei miti (Mt. V,5) nell'interpretazione di S. Ireneo," RSLR 20 (1984): 275-86; Bellinzoni, "The Gospel of Matthew in the Second Century," SecCen 9.4 (1992): 197-269; Bellinzoni, "The Gospel of Luke in the Second Century," in Literary Studies in LukeActs, ed. R. E. Thompson and T. E. Phillips, 59-76 (Macon, GA: Mercer University Press, 1998); G. Stanton, "Jesus Traditions and Gospels in Justin Martyr and Irenaeus," in The Biblical Canons, ed. J. M. Auwers and J. H. de Jonge, 92-109 (Leuven: Leuven University Press, 2003).

${ }^{115}$ P. Ferlay, "Irénée de Lyon exegete du quatrième évangile," NRT 106.2 (1984): 222-34; J. M. Poffet, "Indices de reception de l'évangile de Jean au II e siècle, avant Irénée," in Communauté johannique et son histoire, 305-26 (Genova: Labor et Fides, 1990); Charles Hill, "Irenaeus of Lyon," in The Johannine Corpus and the Early Church, 95-118 (Oxford: Oxford University Press, 2004).

${ }^{116}$ Bernhard Mutschler, Irenäus als johanneischer Theologe (Tübingen: Mohr Siebeck, 2004); Bernhard Mutschler, Das Corpus Johnneum bei Irenäus von Lyon (Tübingen: Mohr Siebeck, 2006).

${ }^{117}$ Mutschler, Irenäus, 84.
} 
scholar has noted frustration with Noormann's isolation of Irenaeus' use of Paul apart from his use of other scriptural material, which is essential to his polemical arguments (cf. AH 5.13.2). ${ }^{118}$ Reed compares Noormann to Bingham's analysis that frequently mentions texts read in continuity with Matthew, and observes in his conclusion that Irenaeus reads Matthew "inter-textually." ${ }^{119}$ Given this trajectory of research, there is an obvious separation between the intertextual nature of the Bishop's exegesis, and the methodological approaches to studies of Irenaeus use of scripture. Although Irenaeus' reading of Genesis has been the subject of recent debate, these works perpetuate the same tendencies.

\subsubsection{Irenaean Studies on Genesis}

While the literature evaluating some portion of the New Testament in Irenaeus is extensive, appreciation for the Old Testament remains scant. With the exception of Genesis, Irenaeus' reading of any Old Testament passage or book is reserved to a few studies on the Psalms or Isaiah. ${ }^{120}$ Clearly Genesis has received the most attention and other than a few studies on key theological issues or persons such as Abraham and Isaac, most studies on Genesis are reserved to the opening chapters. ${ }^{121}$ Many of the Pauline studies mentioned previously occasionally explain the function of Gen 1-3, but most of the evaluations of Gen 1-3 are found in the theological studies, such as works on Irenaeus' anthropology. J. T. Nielsen (1968) was the first to offer critical evaluation of the Adam-Christ typology in Irenaeus. ${ }^{122}$ Orbe (1969) also published his work on the Bishop's anthropology, which contains discussions of the key Genesis

\footnotetext{
${ }^{118}$ Annette Yoshiko Reed, "Review of Rolf Noormann, Irenäus als Paulusinterpret," unpublished conference presentation, Presented at the North American Patristics Society, Annual Meeting Book Session: Irenaeus in Recent Scholarship, May 29, 2004. Pheme Perkins, Review of Rolf Noormann, Irenäus als Paulusinterpret, CBQ 58 (1996): 762-764.

${ }^{119}$ Bingham, Irenaeus', 304. See also: Bingham, “Irenaeus reads Romans 8," 128-29.

${ }^{120} \mathrm{~J}$. A. Aldama, "La naissance du Seigneur dans l'exégèse patristrique du Ps 21:10s (=22:10a)," RSR 51 (1963): 5-29; H.-J. Vogt, “Die Geltung des AT bei Irenäus von Lyon,” ThQ 60 (1980): 17-28; C. Basevi, "La generazoine eternal di Cristo nei Ps 2 e 109 secondo S. Giustino e S. Ireneo," Aug 22.1-2 (1982): 135-47. Lawson provides a general analysis of Irenaeus' reading of Isaiah and select Psalms. Lawson, Biblical Theology, 55-66.

${ }^{121}$ D. E. Lanne, “La 'xeniteia' d'Abraham dans l'oeuvre d'Irénée,” Irén 47 (1974): 163-87; R. Tremblay, "La signification d' Abraham dans l'oeuvre d'Irénée de Lyon,” Aug 18 (1978): 434-57; J. Roldanus, "L'héritage d'Abraham d'après Irénée," in Text and Testimony: Essays on New Testament and Apocryphal Literature in Honour of A. F. J. Klijin, ed. T. Baarda, 212-24 (Kampen: Kok, 1998); B. D. Chilton, "Irenaeus on Isaac," in StuPat 17.2 ed. E.A. Livingstone 643-47 (Oxford: Pergamon Press, 1982).

${ }^{122}$ J. T. Nielson, Adam and Christ in the Theology of Irenaeus of Lyon (Assen: Van Gorcum, 1968). See also: J. A. Aldama, “Adam, typus futuri," SE 13 (1962): 266-80.
} 
passages. ${ }^{123}$ After these publications, more recent studies assessed various aspects of the Bishop's theological systems and, in doing so, comment on relevant Genesis passages including: Brown (1975), Donovan (1988), Constantelos (1989), Fantino (1986, 1992, 1998), Sesboüe (2000), Behr (2001), Weinandy (2003) and Steenberg (2004). ${ }^{124}$ But these studies are theologically oriented, and they methodologically systematize Irenaeus' arguments rather than examine the scriptural basis for his argument or the contribution of Genesis. For example, Nielsen's critical evaluation of the Adam-Christ typology only references Irenaeus' use of Genesis in a few instances, even though echoes and allusions pervade nearly all of his citations of Irenaeus. ${ }^{125}$ They also rarely evaluate the performance (or interrelationship) of scripture in Irenaeus' argumentation. As a result, the assessment of Irenaeus' interpretation of Genesis is a recent development. The importance of Genesis went undetected in earlier works. Lawson, for example, provides a whole chapter of Irenaeus' exegesis and only explores Irenaeus' reading of Isaiah, a few select Psalms, and Romans. ${ }^{126}$ According to Lawson, Irenaeus is chiefly concerned with old Testament prophecy and Paul; there is no substantial reference to the function of Genesis. This view, however, has come full-circle in recent years with HolsingerFriesen arguing that, for Irenaeus, Gen 1:26 and Gen 2:7 are "peerless” in relation to all other biblical texts. ${ }^{127}$ Within this spectrum, there has been a series of studies that endeavored to isolate Irenaeus' reading of Gen 1-3, including works of Orbe, Kannengiesser, Jacobsen, and Steenberg.

\footnotetext{
${ }^{123}$ Orbe, Anthropologia.

${ }^{124}$ Robert F. Brown, "On the Necessary Imperfection of Creation: Irenaeus' Adversus haereses IV, 38," SJT 28.1 (1975): 17-25. Mary Ann Donovan, "Alive to the Glory of God: A key Insight in St. Irenaeus," TS 14.2 (1990): 99-112; J. Demetrios Constantelos, "Irenaeus of Lyon and his Central Views of Human Nature," SVTQ 33.4 (1989): 351-63. Jacques Fantino, L'homme, image de Dieu chez saint Irénée de Lyon, (Paris: Editions du Cerf, 1986); Jacques Fantino, "La creation ex nihilo chez saint Irénée," RevueSPT 76.3 (1992): 421-42; Jacques Fantino, "Le passage de premier Adam au second Adam comme expression de salut chez Irénée Lyon," VC 52.4 (1998): 418-29; Bernard Sesboüe, Tout Récapituler dans le Christ: Christologie et sotériologie d'Irénée de lyon (Paris: Desclée, 2000); Behr, Asceticism. Thomas Weinandy, "St. Irenaeus and the Image Dei: The Importance of Being Human," Logos 6.4 (2003): 15-34; Matthew Steenberg, "Children in Paradise: Adam and Eve as 'Infants' in Irenaeus of Lyon," JECS 12.1 (2004): 1-35.

${ }^{125}$ Nielson, Adam and Christ, 17, 79.

${ }^{126}$ Lawson, The Biblical Theology, 55-86.

${ }^{127}$ Thomas Holsinger-Friesen, Irenaeus and Genesis: A study of Competition in Early Christian Hermeneutics (Winona Lake, IN: Eisenbrauns, 2009), 40.
} 


\subsubsection{Antonio Orbe, Charles Kannengiesser and Anders-Christian Jacobsen}

The first works to consider Irenaeus' reading of Genesis are three articles that, in varying degrees, isolate the Bishop's reliance upon these texts. Orbe composed an article on the complex interpretation of Gen 2:17b in AH 5.23.1-2 and later analyzed his use of Gen 3:15. ${ }^{128}$ His focused treatment on Gen 2:16-17 locates no less than five plausible interpretations that Irenaeus offers of this divine prohibition. Each one proves God is true and the serpent is a liar (John 8:44), because Adam and Eve truly died the day they ate of the fruit. Orbe shows us that, in the midst of his polemics, Irenaeus will provide highly intense readings of particular terms, phrases, and concepts in Genesis that contribute to his theological argument. Given the breadth of interpretive options, he is also comfortable with any interpretation that proves the veracity of God's prohibition in Gen 2:17. But in this article, as well as his treatment of Gen 3:15, Orbe does not emphasize that these various readings are dependent upon distinctive textual relationships.

While Orbe's article is highly focused, Charles Kannengiesser's article entitled, “The «Speaking God» and Irenaeus' Interpretative Pattern: The Reception of Genesis," is much more general as it evaluates the function of Genesis as a whole in Irenaeus. ${ }^{129}$ Kannengiesser's attention to the performance of Genesis discerns several interesting features of Irenaeus' use of Genesis passages including his preference for texts that contain divine discourse and the way Irenaeus' allusions to Genesis throughout $A H$ follows, more or less, the contours of the biblical narrative itself. However, by his own admission, Kannengiesser's methodology “deliberately ignores the connections established between Genesis and other biblical books and proceeds in a methodological abstraction to postpone more complex inquiries." ${ }^{130}$ While his thesis and inclination is right, Kannengiesser's move to ignore the connections between Genesis and other passages actually inhibits his goal of

\footnotetext{
${ }^{128}$ Orbe, "Cinco exegesis Ireneanas de Gen 2:17b adv. haer. V 23, 1-2," Greg (1981): 75-113; Orbe, "Ipse tuum calcabit caput, San Ireneo y Gen 3:15," Greg 52 (1971): 71-127.

${ }^{129}$ Charles Kannengiesser, “The «Speaking God» and Irenaeus' Interpretative Pattern: the Reception of Genesis," ASE 15.2 (1998): 337-352.

${ }^{130} \mathrm{Ibid}$., 339. This also does not address the fact that Kannengiesser limits his investigation to "quotations."
} 
identifying the very "motivation" and the "methods" of Irenaeus as an interpreter of scripture..$^{131}$

Another significant article surfaced in 2004 by Anders-Christian Jacobsen entitled "The Importance of Genesis 1-3 in the Theology of Irenaeus."132 Similar to Kannengiesser, Jacobsen aims for a deeper appreciation of Irenaeus' exegetical strategies as the "unavoidable first step" in the appreciation of his theological framework. ${ }^{133}$ He argues for the formative role of Gen 1-3 in Irenaeus' theological integration of creation and consummation and the anthropological implications of humanity's creation in the image of the divine Logos. ${ }^{134}$ Irenaeus' vision of salvation is the fulfillment of the conditions of creation established in the opening scenes of Gen 1-3. He rightly argues that Irenaeus explains the central issues of the faith with "biblical key-texts," but Jacobsen nowhere mentions the way Irenaeus reads Gen 1-3 within theological networks or how textual networking constructs his theological vision. He only mentions a handful of scriptures outside Gen 1-3 and concentrates exclusively on establishing some general guidelines for the contribution of Gen 1-3 (especially Gen 1:26 and Gen 2:7) for Irenaeus' theological framework. Like Kannengiesser, Jacobsen's general thesis is helpful but his observations regarding Gen 1-3 are stifled because he also overlooks Irenaeus' scriptural networking.

\subsubsection{Matthew Steenberg and Thomas Holsinger-Friesen}

Finally, recent years have witnessed the publication of two monographs on Irenaeus' use of Genesis: the 2008 work by Matthew Steenberg, entitled Irenaeus on Creation: The Cosmic Christ and the Sage of Redemption, and the 2009 publication by Thomas Holsinger-Friesen entitled, Irenaeus and Genesis: A study of Competition in Early Christian Hermeneutics. Steenberg also revised a portion of his monograph on Gen 2:16-17 and published an article that extends the previous work of Orbe on the same

\footnotetext{
${ }^{131}$ Ibid., 339. For example, Irenaeus most frequently cites the dialogical texts in Genesis in continuity with New Testament dialogical texts, such as Christ "speaking" in the Gospels, in order to link the identities of both individuals. See AH 5.17.1 with the allusions to Gen 3:9 and Jn 9:1-7.

${ }^{132}$ Anders-Christian Jacobsen, "The Importance of Genesis 1-3 in the Theology of Irenaeus," ZAC 8 (2004): 299-316.

${ }^{133}$ Ibid., 316. Orbe also shares this general sentiment. Orbe, Teología V.1, 10.

${ }^{134} \mathrm{Ibid}$., 299. While Genesis may play a formative role in, say his theological concept of recapitulation, it is not Gen 1-3 alone, but Gen 1-3 in dialogue with other texts (i.e. Eph 1:10, Rom 5:12, and 1Cor 15:45-47).
} 
text. ${ }^{135}$ Steenberg's volume is an analysis of Irenaeus' use of Gen 1-11, which attempts to read "the author's varied cosmological and anthropological statements within a larger interpretive framework on creation and the human person." ${ }^{136}$ Even though Irenaeus has long been regarded as a "theologian of creation," Steenberg's work is the first systematic treatment of Irenaeus' reading of any Old Testament book or extended pericope. ${ }^{137} \mathrm{He}$ also frames Irenaeus' theology of creation within the patterns of early Christian thought and compares his thought with Justin, Theophilus, and the Gnostic literature. Steenberg recognizes, however, that Irenaeus presents no single isolated treatment of the creation accounts, instead his reflections on creation are scattered throughout his work and woven into his varied theological and polemical reflections. Citing the language of C. R. Smith, he sets out to prove that Irenaeus is a "consistent creationist," thereby orienting his analysis of Gen 1-11 toward the "interrelationships" amid Irenaeus' protology and other aspects of his theological perspective. ${ }^{138}$ Steenberg realizes the fallacy of packaging Irenaeus' theology into isolated doctrines that disrupt the integrated nature of his theological framework. Irenaeus' Christology and anthropology, for example, are closely aligned with his protology and eschatology. ${ }^{139}$

Nevertheless, we cannot overlook that Steenberg's monograph is a revised version of his Oxford D. Phil. thesis originally titled: Cosmic Anthropology: Gen 1-11 in Irenaeus of Lyon with special reference to Justin, Theophilus and select Gnostic contemporaries. The title and focus of the work was altered for publication, and this transition calls into question the extent of his conclusions. ${ }^{140}$ On one hand, Steenberg must acknowledge that Gen 1-11 is "hardly the sole testimony to creation

\footnotetext{
${ }^{135}$ Steenberg, "To Test or Preserve?: The Prohibition of Gen 2:16-17 in the Thought of Two SecondCentury Exegetes," Greg 86 (2005): 723-41.

${ }^{136}$ Steenberg, Irenaeus, 4.

${ }^{137}$ Ibid., 5.

${ }^{138}$ Ibid., 2, 9. C. R. Smith, "Chiliasm and recapitulation in the theology of Irenaeus [sic]," VC 48 (1994): 313-331, 320.

${ }^{139}$ I do not prefer the language "protological" that pervades the works of Holsinger-Friesen, Steenberg, Behr, and others. This modern categorization runs the risk of anachronism and continues to force Irenaeus' use of scripture into rigid categories he does not use. In other words, what Irenaeus conceives as "protological" cannot be reserved to Gen 1-3ff, but must include reference to other texts with creation themes and concepts. These texts, furthermore, are not altogether disconnected from his use of other theologically and hermeneutically related texts. However, given the prominence of this term in the literature, we continue to use it here, but when we do so it refers to Irenaeus' understanding of cosmogony.

${ }^{140}$ Steenberg, "Cosmic Anthropology: Gen 1-11 in Irenaeus of Lyon with special reference to Justin, Theophilus and select Gnostic contemporaries," unpublished dissertation (University of Oxford, 2003).
} 
contained in the scriptures," because Irenaeus will fashion his theology of creation without mentioning Genesis, and yet the basis of research remains the allusions and citations to Gen 1-11, even though Irenaeus uses a range of passages outside of Gen 1-11 to fashion his theology of creation. ${ }^{141}$ Thus, the object of Steenberg's research is concerned with the "interrelation" of Irenaeus' theology of creation with the rest of his theological perspective, not appreciating the way Irenaeus exegetes Gen 1-11 or reads these texts in continuity with other scriptures. ${ }^{142}$ Moreover, Steenberg's theological concerns also overlook the more fundamental analysis of terms, phrases, images or concepts imbedded in Gen 1-3 and the way these orient the interrelational nature of Irenaeus' exegesis of Gen 1-3 that informs his theological perspective. Steenberg readily acknowledges Irenaeus' tendency to conflate Gen 1-3 with other texts and he also observes that Irenaeus reads Genesis in continuity with the rest of salvation history. ${ }^{143}$ However, Steenberg rarely scrutinizes the host of scriptural allusions that stand in interpretative relationship with Gen 1-3, because evaluating these scriptural interrelationships is not essential to his methodology. ${ }^{144}$ What we have in Steenberg, therefore, is not Irenaeus' comprehensive theology of creation shaped by all creation passages, or the analysis of interrelated creation texts, but Irenaeus' theology of creation with respect to explicit allusions and citations of Gen 1-11. ${ }^{145}$ As a result, this present intertextual evaluation will

\footnotetext{
${ }^{141}$ Steenberg, Irenaeus, 61. For example Psalm 33:6 LXX and John 1:1-3 are essential to his theology of creation. Furthermore, Irenaeus can speak about creation or utilize creation imagery and never appear to reference Gen 1-3. See also: AH 4.19.2 which alludes to Isa 40:12 and Eph 3:18, 21.

Steenberg's monograph is still organized by allusions to Gen 1-11; cf. Steenberg Irenaeus, 5, 61.

${ }^{142}$ Steenberg, Irenaeus, 9.

${ }^{143} \mathrm{Ibid}$., 66. He goes so far as to point out that $A H$ 1.22.1, AH 2.2.5 and Epid 43 all conflate Gen 1:1 with John 1:1-3 and the immediate context also contain allusions to Psalm 32:6 and 9, respectively. The under appreciation for Irenaeus' intertextual reading of Gen 1-3 is also evidenced when he claims that "no single verse of New Testament writings is of stronger influence on Irenaeus' cosmological considerations than John 1:3." While John 1:3 may be essential, as we will show it participates in a much broader intertextual reading of Gen 1-3. Ibid., 69.

${ }^{144}$ For examples of discussion of scriptural interactions see: Steenberg, Irenaeus on Creation, 58-9, 66, 69, and 70-1. Generally speaking I cannot agree with Steenberg's arbitrary analysis of Gen 1:26. He distinguishes between intentional and unintentional references Genesis in his use of the language "image and likeness." There are no instances where Irenaeus uses this language that he does not, on some level, have the creation accounts in view. Steenberg, Irenaeus, 217; cf. Ibid., 73-4.

${ }^{145}$ While some might object to the validity of certain echoes or allusions to Gen 1-3, it is more responsible to be exhaustive and address all potential references to Gen 1-3. As Bacq has proven, closer scrutiny of Irenaeus' less obvious allusions is necessary for understanding the Bishop's argument, structure, and exegesis. Bacq, De l'ancienne, 19-20. See also: Orbe, Teología V.1, 10, Bingham, Irenaeus', 12, and Donovan, One Right Reading?, 17. Louis Painchaud argues the same thesis for the use of scripture in Gnostic literature. Louis Painchaud, "The Use of Scripture in Gnostic Literature," JECS 4.2 (1996): 129-47, 130-1. That being said, we have not been uncritical in our analysis of the uses of
} 
supplement his contribution and extend his exegetical evaluation of Irenaeus' use of Gen 1-3.

Finally, Holsinger-Friesen offers the most recent contribution on Irenaeus' use of Genesis. His monograph is the inaugural volume of the supplemental series to the Journal of Theological Interpretation and, as the subtitle suggests, is more hermeneutically focused. Following the lead of Kannengiesser, his evaluation of Genesis is explicitly focused on illuminating Irenaeus' exegetical methodology in light of his interlocutors. ${ }^{146}$ Holsinger-Friesen rightly argues that theological investigations of Irenaeus have, by and large, undervalued his more fundamental exegetical methodology. ${ }^{147}$ But despite the implication of his title, Holsinger-Friesen is not concerned with Irenaeus' reading of Genesis as a whole, nor even Gen 1-2, but with the Bishop's reading of Gen 1:26 and Gen 2:7, insofar as they elucidate his “innovative manner of reading biblical texts as Christian Scripture." ${ }^{148}$ Irenaeus' use of Gen 1:26 and Gen 2:7 is a mere "test-case" to this end and his evaluation is highly selective. $^{149}$

Consequently, Holsinger-Friesen regularly devalues Irenaeus' intertextual connections when he chooses to evaluate Gen 1:26 and Gen 2:7 in isolation. ${ }^{150}$ In his analysis we see glimpses of Irenaeus' theological weaving of scripture, and he even acknowledges Irenaeus' thought proceeds from the "conjunction" of texts, but Holsinger-Friesen does not accentuate these relationships or elucidate the more intricate nature of Irenaeus' textual harmony. ${ }^{151}$ Instead, he focuses on the utilitarian nature of Gen 1:26 and Gen 2:7 within the hermeneutical disputes of the second century, and frequently describes each as a "hermeneutical tool," even though Irenaeus never uses one scripture (or one "tool") to refute the Gnostics, but

Gen 1-3 listed in $B P$ and $S C$. In the introduction to each chapter we mention instances where we disagreed with $B P$ or $S C$ on the cited use of Gen 1-3.

${ }^{146}$ Holsinger-Friesen, Irenaeus, 106-7.

${ }^{147} \mathrm{Ibid}$, x. His work is set in opposition to the influence of Adolf von Harnack whose inflated view of Irenaeus' doctrine of recapitulation, according to Holsinger-Friesen, has dominated scholarly discussions of Irenaeus to the present day. For a similar observation See Jacobsen " The Importance of Genesis 1-3," 300-1 n2.

${ }^{148} \mathrm{Ibid}$., 2. He does not examine all of Irenaeus' uses of Gen 1:26 and Gen 2:7. His evaluation is reserved to the Gnostic uses in $A H$ 1.1-7 and $A H$ 1.30.1-9 and a few selective uses in $A H$ 3.18, AH 4.20 and $A H$ 5.3-16.2.

${ }^{149}$ Ibid., 142, 219.

${ }^{150}$ Holsinger-Friesen, Irenaeus, 218-21. As we have argued below there are good reasons to explore Gen 1-3 as a unit in Irenaeus, and the way these texts contribute to his intertextual argumentation. Ibid., 215.

${ }^{151}$ Holsinger-Friesen, Irenaeus, 38. 
a collection of scriptures linguistically, theologically, structurally, or conceptually bound together. ${ }^{152}$ Therefore, while Gen 1:26 and Gen 2:7 may be pivotal in many instances, they are not "peerless" because they participate in the intertextual relationships of Irenaeus' interpretative mosaic. ${ }^{153}$ The assumption of HolsingerFriesen's methodology also presumes they are competing over the same particular texts, when in reality the Gnostics are not competing interpretations of the same individual passages, but competing networks of texts, or "systems of Scriptural interpretation" that are distinctive, even though they retain some similar individual elements. ${ }^{154}$

Holsinger-Friesen's primary conclusion is what he terms Irenaeus' "protological orientation" that privileges the theological and Christological application of Gen 1:26 and Gen 2:7. ${ }^{155}$ This may be a helpful corrective to the earlier studies of Steenberg and Behr who argue that Irenaeus is eschatologically oriented even in terms of his use of Gen 1-2. ${ }^{156}$ But Irenaeus' exegesis is not altogether protologically oriented; rather it is clearly intertextually oriented (AH 1.8.1, AH 1.9.4, AH 2.28.3, AH 3.12.9). He is not concerned with Gen 1:26 or Gen 2:7 alone at any stage of salvation history, but instead with Genesis in connection with others texts. At times the texts of Gen 1-3 function as controlling texts ordering his argument, while in other instances Gen 1:26 or Gen 2:7 are supporting texts that buttress his theological positions. Therefore, Irenaeus is not concerned purely with the protological matters, but with the way all portions of scripture are ordered and connected as they anticipate the eschatological kingdom of God.

\footnotetext{
${ }^{152} \mathrm{Ibid} ., 40,108$. The better analogies are those Irenaeus uses himself including: the mosaic (AH 1.8.1), the Homeric poem (AH 1.9.4), or the hymnic melody ( $A H$ 2.28.3); $c f . A H 1.3 .6 ; A H$ 3.11.8; $A H$ 3.12.12; $A H$ 3.13.3; AH 4.pf.4; AH 4.32.1; AH 5.13.2; 5 AH 5.2.1-2.

${ }^{153} \mathrm{Ibid}$., 40. In the same context he continually refers to them as "focal texts" which also construes the harmonious nature of Irenaeus' hermeneutics. Ibid., 33, 39. He also separates Irenaeus' reading of Gen 1-2 from Gen 3, even though there is clear precedent for evaluating these chapters together. Ibid., 38-9.

${ }^{154}$ Moringiello, Irenaeus Rhetor, 15; Holsinger-Friesen, Irenaeus, 3-4, 39-40. Elsewhere Moringiello states that these competing "systems of belief" are best understood as hermeneutical tools meant to aid scriptural interpretation. Ibid., 40. Holsinger-Friesen also suggests that Gen 1:26 served as a "common starting point in the debate," but due to the complex Gnostic revisions of the Genesis narratives, he expands his analysis to the Gnostic reading of Gen 1-3. Ibid., 139, 51-103.

${ }^{155}$ For a discussion of the term "protological" see n. 135.

${ }^{156}$ Steenberg, Irenaeus, 9. He also suggests Irenaeus' use of "image and likeness" in Gen 1:26 is "eschatologically oriented." Steenberg, Irenaeus, 56; cf. Steenberg, of God and Man, 42-3. Steenberg will use the language of "protological orientation," but he is specifically speaking of Irenaeus' reading of the creation accounts as the opening scenes of the divine economy, not the reference to Genesis in the latter stages. Steenberg, of God and Man, 22.
} 
Therefore, the works of Orbe, Kannengiesser, Jacobsen, Steenberg, and Holsinger-Freisen all point to the need for a closer evaluation of the nature of the Bishop's hermeneutics and his intertextual reading of Genesis in particular. Situated between the emphasis on the theological integration of Irenaeus' thought in Steenberg, and the importance of Irenaeus' hermeneutics in Kannengiesser, Jacobsen, and Holsinger-Friesen, we advance the understanding of Irenaeus' reading of Gen 1-3 by showing the sophistication of his textual networking and the way he orders and connects Gen 1-3 through a variety of reading strategies. Contrary to the restrictive methods applied to Irenaeus in previous studies, we will be sensitive to Irenaeus' intertextual scriptural interpretation, and evaluate not only the meaning of Gen 1-3, but also the other scriptural texts exist in a interpretative symbiotic relationship with Gen 1-3. From this evaluation we will be able to explain how the Bishop of Lyon networks texts as he defends his understanding of the apostolic faith.

\subsection{Methodology and Qualifications}

\subsubsection{Introduction}

For several reasons we have chosen to evaluate the intertextual reception of Gen 13 in Irenaeus. First, the material of Gen 1-3 is cited considerably throughout Irenaeus' corpus. Following Isaiah and the Psalms, it is the most frequently cited portion of the Old Testament. ${ }^{157}$ In his analysis Kannengiesser casually remarks that Gen 1-3 appears to sit at the forefront of Irenaeus' mind due to the extensive range of allusions. ${ }^{158}$ So, we have many and various textual relationships to compare. Second, the creation accounts have long been recognized as central to Irenaeus' theological framework, so much so that he is frequently characterized a "theologian of creation." ${ }^{159}$ If creation is essential to Irenaeus' thought, this concentration on the intertextual reception of Gen 1-3 will provide an array of scriptural texts that are essential to this theological framework. Third, Irenaeus views the events of Gen 1-3 as a collective unit because they all transpire on the same "day of creation." ${ }^{160}$ For Irenaeus the creation of Adam and Eve, their disobedience, and their expulsion (Gen

\footnotetext{
${ }^{157}$ Holsinger-Friesen, Irenaeus, 4 n. 14.

${ }^{158}$ Kannengiesser, The 'Speaking God', 350.

${ }^{159}$ Steenberg, Irenaeus, 1.

${ }^{160}$ Iain MacKenzie, Irenaeus's Demonstration of the apostolic preaching : a theological commentary and translation (Burlington, VT: Ashgate, 2002), 119; cf. AH 5.23.2
} 
1:26-3:24) take place on the sixth day of creation. Fourth, Irenaeus' doctrines are inundated with references to creation. He is greatly interested in the notions of salvation history and the economic connections between creation and eschatology. As Steenberg puts it, "Nowhere in his thought will Irenaeus consider the later events of the economy-the incarnation, the passion, the resurrection-without explicit reference back to the first moments of God's creative act." ${ }^{161}$ Finally, Irenaeus' chiliastic vision of the cosmos forces him to read the "beginnings" and the "ends" together. This aesthetic parallelism fashions decisive scriptural harmonies between Gen 1-3 and salvation history. ${ }^{162}$ Furthermore, in AH 5.28.3, Irenaeus explicitly states he reads the creation accounts in two senses. They are indeed a literal account of creation, but also a "prophecy of what is to come" (futrorum prophetia). So, while Irenaeus is concerned with the order, connection, and harmony of all scriptures, he is particularly concerned with the relationship of Gen 1-3 to the rest of salvation history. Given these arguments, it is necessary to evaluate Gen 1-3 as a scriptural unit, and they way Irenaeus links these texts to the rest of the scriptural witness.

\subsubsection{Methodology}

Though we have argued that the method of this study extends previous analysis of Irenaeus' use of scripture, it is not without precedent. ${ }^{163}$ For the intertextual analysis of scripture, Ellen Van Wolde proposes the following procedure: (1) identify a particular intertextual relationship between two or more texts and study each text on its own, (2) compose an inventory of the repetitions of the compared texts, (3) analyze the new network of meaning generated from the meeting of the two texts. S. D. Giere follows a modified version of Van Wolde's criteria. Giere's study is also a diachronic analysis assessing a broad range of ancient texts. Our study, on the other hand, is a focused synchronic examination of a singular pericope throughout

\footnotetext{
${ }^{161}$ Steenberg, Irenaeus, 21.

${ }^{162}$ Smith, “Chiliasm," Steenberg, Irenaeus, 49-60.

${ }^{163}$ James W. Voelz, "Multiple Signs and Double Texts: Elements of Intertextuality," in Intertextuality In Biblical Writing: Essays in honour of Bas van Iersel (Uitgeversmaatschappij J. H. Kok: Kampen, 1989); Ellen Van Wolde, "Texts in Dialogue with Texts: Intertextuality in the Ruth and Tamar Narratives," BibInt 5.1 (1997); S. D. Giere, A New Glimpse of Day one: Intertextuality, History of Interpretation, and Genesis 1:1-5 (Walter de Gruyter: Berlin, 2009). Van Wolde is effectively a simplified version of Voelz's more detailed approach and Giere follows Van Wolde with some modifications. Stead synthesizes a diachronic and synchronic approach in his "“contextual' intertextuality." Stead, The Intertextuality of Zechariah 1-8, 18-9.
} 
the work of a single author. In our present study we will apply a revised version of Van Wolde's procedure, which has other similarities to Giere.

First, we have identified all the allusions to Gen 1-3 in Adversus Haereses. ${ }^{164}$ The basis for this identification is the indices of the critical editions in Sources Chrétiennes (SC), and we have also cross-referenced these allusions with those cited in Biblia Patristica (BP) to ensure that all relevant texts are identified. We have also compared these allusions with the passages identified in Antonio Orbe's translation and commentaries of $\mathrm{AH} 4$ and $\mathrm{AH} 5 .^{165} \mathrm{BP}$ is much more generous, and not all suggested allusions could be verified or accepted. We have noted these instances in the introduction to each appropriate chapter.

Second, we have identified the intertexts that are hermeneutically and contextually linked with the allusions to Gen 1-3 in Irenaeus. In most cases these intertexts are scripture passages, but there are also several extra-biblical references. The identification of these intertextual allusions will rely again upon SC and BP. The references to Gen 1-3 and the intertext(s) form the intertextual relationship(s) that are the focus for this study. As we will show, the relationship between Gen 1-3 and the intertext(s) sheds light upon the "meaning and function" of Gen 1-3 in Irenaeus. ${ }^{166}$ We readily admit that this notion of "text" and "intertext" are a framework imposed upon Irenaeus and the use of "text" or "intertext" does not assume priority or hierarchy within the rhetorical argumentation of Irenaeus. ${ }^{167}$

Third, we have identified theological, structural, or linguistic markers uniting the texts. ${ }^{168}$ Similar to Van Wolde's second step, these repetitions and intertextual markers include various "signs" such as: words, semantic fields, concepts, imagery, structures, themes, characters, actions, or narratological representations. ${ }^{169}$ The most consistent means of connection are what Philippe Bacq terms "linking words" or mot chrochets. ${ }^{170}$ However, not all textual connections may be attributed to philological connections. Some are more conceptually, theologically

\footnotetext{
${ }^{164}$ We have identified all the uses of Gen 1-3 in Irenaeus' Epideixis, which we will mention wherever appropriate. However, we will reserve the comprehensive evaluation of the intertextual performance in the Epideixis for a separate publication.

${ }^{165}$ Orbe, Teología IV, V.1-3.

${ }^{166}$ Van Wolde, "Texts in Dialogue", 7.

${ }^{167} \mathrm{cf}$. Clark, Reading, 5.

${ }^{168}$ Van Wolde, "Texts in Dialogue", 7; Giere, A New Glimpse, 12.

${ }^{169}$ Van Wolde, "Texts in Dialogue", 7-8; Giere, A New Glimpse, 12. Voelz refers to this as "matrixed" saying, "...textual events or ideas are matrixed with other textual events or ideas." Voelz, "Multiple Signs," 30 .

${ }^{170}$ Bacq, de l'ancienne, 20.
} 
or structurally related. If we cannot identify any type of intertextual relationship, or if the relationship is not theologically or contextually apparent, we will not make any case for intertextual connections, and we will not argue that these texts contribute to Irenaeus' use of Gen 1-3. This step protects this study from the charge of arbitrary connections that extend ad infinitum.

Fourth, similar to Van Wolde's third step, we will analyze the "new network of meaning" that originates from the connection of Gen 1-3 and the intertext(s). ${ }^{171}$ However, this study is distinct from Van Wolde (but similar to Giere's) in that we are not creating new meanings, but using intertextuality as a "foundational lens through which to make 'new' observations of 'old' exegesis." ${ }^{172}$ This step allows us to make new observations of the meaning and function of Gen 1-3 in Irenaeus and examine how his networking of scripture shapes his theological perspective. Finally, we concluded each chapter with a summary description of Irenaeus' scriptural networking framed by a set of conceptual terms that define the multiple aspects of his intertextual reading of Gen 1-3.

\subsubsection{Categorical Qualifications}

This methodology requires a few categorical qualifications regarding the nature of the scriptural references and interpretive perspective. First, in order to identify direct and indirect references to the scriptural material, we have chosen to follow Stanley Porter's classifications and will distinguish between echo, allusion, and citation to Gen 1-3 and the surrounding intertexts. ${ }^{173}$ Generally speaking, "echo" is reserved for language that is thematically related to a particular text, while "allusion" has a greater degree of specificity with identification of particular terms or concepts related to an identifiable source. A "citation" has even more specificity, and is identified by an explicit grouping of parallel language and terms. As Patricia Tull has argued, these classifications are located on a spectrum of identifiability from unknown to certain. ${ }^{174}$ In light of this fluidity, we must proceed with caution in

\footnotetext{
${ }^{171}$ Van Wolde, “Texts in Dialogue”, 8. Giere, A New Glimpse, 12.

${ }^{172}$ Giere, A New Glimpse, 12.

${ }^{173}$ Stanley E. Porter, "Further Comments on the Use of the Old Testament in the New Testament," in The Intertextuality of the Epistles: Explorations of Theory and Practice, eds. T. L. Broder, D. R. MacDonald, and S. E. Porter, NTM 16, 98-110 (Sheffield: Sheffield Phoenix Press, 2007); S. Porter, "Allusions and Echoes," in As it is Written: Studying Paul's use of Scripture, 29-40 (Leiden: Brill, 2008).

${ }^{174}$ Patricia Tull (Willey), Remember the Former Things: The Recollection of Previous Texts in Second Isaiah (Atlanta: Scholars Press, 1997), 61. See also Stead, The Intertextuality of Zechariah, 20-21.
} 
applying these labels stringently. Typically any more than three parallel terms qualifies as a citation. These classifications are not without implication in Irenaeus. Even though it is worthwhile to analyze the nature of the particular echoes, allusions, or citations, we are more concerned with the intertextual connections between texts than with the qualitative nature of the textual reference or similarity of texts to their original sources. ${ }^{175}$

Second, we will not intentionally classify Irenaeus' particular interpretations as literal, typological or allegorical. The discussion on these terms is extensive and the definitions are far from settled. In many cases, the intertextual relationships we identify in Irenaeus could be classified as typological or even possibly allegorical. Some Irenaean scholars, such as Orbe, continue to argue for the distinction between typology and allegory in Irenaeus, but the Bishop's use of scripture, as we will show, is much more complicated and in many cases not straightforward. ${ }^{176}$ It is especially problematic when Irenaeus composes a network of multifarious echoes or allusions to disparate texts covering both Testaments. ${ }^{177}$ Peter Martens has also made the strong case that the distinction is unhelpful and potentially misleading. ${ }^{178} \mathrm{He}$ proposes the need for alternative labels for the various forms of non-literal interpretations. In light of her discussion on intertextuality, Young also suggests the normative categories of "literal," "allegory," and "typology" are inadequate to describe the practice of patristic exegesis. ${ }^{179}$ Instead, she describes patristic exegesis as "an intertextuality of imaginative and creative play, far removed from the historicism of modern interpretation. ${ }^{180}$ Irenaeus does speak of Paul's Adam-Christ typology, but he also repudiates the use of allegory-even though he appears to utilize allegory-because allegory is characteristic of Gnostic exegesis. For our purposes, therefore, intertextuality simply emphasizes the more general observation that, for Irenaeus, texts exist in relationship and we have formulated a group of conceptual categories that explain how Irenaeus arranges these intertextual relationships.

\footnotetext{
${ }^{175}$ This has been a point of emphasis in many of the works mentioned previously. See for example, Noormann, Irenäus, 28-9.

${ }^{176}$ AH 5.35.1; Orbe, Teología V.1, 12-3.

${ }^{177}$ For example see: $A H$ 3.23.1-8 and $A H$ 4.20.1-4.

${ }^{178}$ Peter Martens, "Revisiting the Allegory/Typology Distinction: The Case of Origen, "JECS 16.3

(2008): 283-317, 315-6. See also: De Lubac, “Typologie' et 'allegorisme” RSR 34 (1947): 180-226. Ayres, Nicaea, 31. Clark, Reading, 70-78.

${ }^{179}$ Young, Biblical Exegesis, 116.

${ }^{180}$ Young, The Art of Performance, 128.
} 


\subsubsection{Potential Limitations}

Having delineated our methodology, we must address some potential limitations. First, we are not concerned with influence or dependence, even though this may be implied from our analysis. While this is an important discussion, identifying dependence in the ancient world is a highly involved task in its own right and well beyond the scope of this study. This chapter has noted several works that labored to find Irenaeus' sources and produced nominal results. ${ }^{181}$ In addition, given the nature of Irenaeus' intertextual orientation, there is greater need for closer scrutiny of Irenaeus' contributions and appreciation of his own argumentation. Second, some scholars have claimed that intertextuality is a dubious category because intertextual connections extend ad infinitium. There is merit to this critique and it is true that these intertextual connections can digress into unmanageable and unconvincing relationships. Therefore, we have limited the intertextual connections to the texts and intertexts in the immediate context linked through some kind of identifiable conceptual relationship. We have limited the connections to the chapter and paragraph of $A H$ in SC containing the allusions to Gen 1-3. However, in a few instances we include an additional paragraph, either before or after, if it is closely related to the same line of argumentation. This analysis also demands close attention to Irenaeus' overall polemic and the structure of his argumentation. The works of Donovan, Bacq, and Orbe were important in order to locate the structure of Irenaeus and to determine the flow of argumentation that links these texts. As we mentioned in step three of the methodology above, if there is no specific or discernable relationship, there is no textual relationship discussed. Third, this mode of investigation consistently struggles against the tendency to discuss intertexts, rather than evaluate Gen 1-3. Again and again, we have pressed against this tendency in attempts not to leave out any potential intertextual insight. While in certain instances it might appear as though Gen 1-3 recedes into the background, it is because we believe the intertexts are essential for understanding the way Irenaeus reads Gen 1-3. That being said, we have made every effort to only discuss passages that in some way inform Irenaeus' reading of Gen 1-3. Despite these potential limitations, any discussion of Gen 1-3 that ignores these intertextual

\footnotetext{
${ }^{181}$ Wingren, Man and the Incarnation, xvi-ii.
} 
relationships misconstrues Irenaeus' hermeneutical perspective and the intentions of his scriptural exegesis.

\subsubsection{Conclusion}

Therefore, informed by contemporary discussions on intertextuality in Fishbane, Boyarin, Hays and Young we have gained a greater appreciation for Irenaeus' intertextual reading of scripture. Previous studies on Irenaeus' use of scripture overlooked his own hermeneutical perspective, and systematically disconnected the textual networks he intentionally fashioned. In terms of Genesis, Orbe, Kannengiesser, and Jacobsen turned our attention to his reading of Genesis and the significant contribution of this book to Irenaeus' theological vision. Following these studies, Steenberg highlighted the theological integration of Irenaeus' thought with respect to his use of Gen 1-11. Irenaeus' views on creation are consistent with the entire thrust of this theological framework. Finally, Holsinger-Friesen, in concert with Kannengiesser and Jacobsen, continued to evaluate the nature of Irenaeus' scripture hermeneutic. Bringing these studies together, we see the need for closer examination of the intertextual nature of Irenaeus' hermeneutics as it applies to Gen 1-3, and the way he networks these creation texts with the rest of the salvation history. In this study, therefore, we demonstrate Irenaeus' intertextual reading of Gen 1-3 by means of the textual relationships he fashions with these protological texts, and outline the specific means by which Irenaeus arrives at these specific textual relationships. With Gen 1-3 as our textual landmark, we will show how Irenaeus utilizes these texts in continuity with other scriptural passages. This mode of enquiry is more sensitive to Irenaeus' expressed methods of exegesis and the range of studies on his exegetical methodology, and this manner of intertextual inquiry will reveal a deeper appreciation for his reading of Gen 1-3 than any study to date. To this intertextual reception of Gen 1-3 in Irenaeus we now turn. 


\section{CHAPTER 2: THE INTERTEXTUAL RECEPTION OF GENESIS 1-3 IN BOOK 1 OF ADVERSUS HAERESES}

\subsection{Introduction}

In the preface to $A H 1$, Irenaeus explains that he is writing to expose the origin, nature, and doctrine of the so-called "Gnostic" communities found in Lyon and throughout the Mediterranean region. ${ }^{1}$ In particular, he points to the Valentinian school of thought found in the followers of Ptolemaeus. ${ }^{2}$ While Valentinus was centered in Rome, his teaching, proliferated through his followers, was making its way westward into Irenaeus' own Rhone Valley. ${ }^{3}$ Irenaeus claims to have had some interaction with Valentinus in Rome and direct communication with other sects. ${ }^{4}$ His stated purpose of "exposing" (manifestare) and "refuting" (evertere) the theological claims of his opponents is discernable in the title provided by Eusebius, Refutation and Overthrow of Knowledge Falsely So-called, or the shortened form, Against the Heresies. ${ }^{5}$

To this end, AH 1 unfolds as a carefully summarized theological catalogue of Ptolemean Valentinianism and other related streams of Gnosticism, with particular attention given to the theological and cosmological framework of each sect. ${ }^{6}$ Excluding the preface in $A H$ 1.pf.1-2 and the conclusion in $A H$ 1.31.3-4, the contents

\footnotetext{
${ }^{1}$ AH 1.pf.1. Following the significant contributions of Michael Williams and Karen King, the labels "Gnostic" and "Gnosticism" continue to be problematic and potentially misleading. Wherever possible I will identify the specific school or community in view. However, some of Irenaeus' discussions are intentionally general thus the more inclusive titles are necessary as indicators of all the groups Irenaeus' mentions throughout AH. See Williams, Rethinking "Gnosticism." Karen L. King, What Is Gnosticism? (Cambridge: Harvard University Press, 2003). For a similar suggestion see Steenberg, Irenaeus, 15. For a discussion of various labels Irenaeus' gives his Valentinian opponents see Einar Thomassen, The Spiritual Seed: The Church of the 'Valentinians' (Leiden: Brill, 2006), 13-22.

${ }^{2}$ AH 1.pf.2. He also mentions Ptolemaeus in AH 1.12.1; AH 2.4.1.

${ }^{3} \mathrm{AH}$ 1.13.7. This is likely why Irenaeus was concerned with the Valentinians first and foremost. Grant, Irenaeus, 21.

${ }^{4}$ W. C. Van Unnik, Newly Discovered Gnostic Writings: A preliminary survey of the Nag Hammadi find (London: SCM Press, 1960), 62. For a discussion on the reliability of Irenaeus' representation see: Steenberg, Irenaeus, 11; Thomas Holsinger-Friesen, Irenaeus, 43-50; Thomassen, The Spiritual Seed, 1213; Perkins, "Irenaeus and the Gnostics: Rhetoric and Composition in Adversus Haereses Book One," VC 30 (1976): 193-200. The summary of the contents of $A H 1$ is also found in AH 2.pf.1. See David Tripp, “The Original Sequence of Irenaeus ‘Adversus Haereses' 1: A Suggestion,” SecCent. 8 (1991): 157-62.

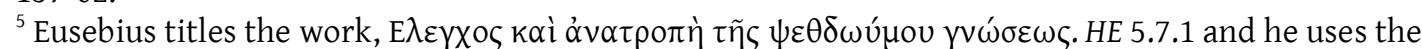
abbreviated title Adversus Haereses in HE 3.23.3. Irenaeus suggests this title in AH 2.pf.1, 4.pf.1, and 5.pf.1.

${ }^{6}$ On the relationship (or lack there of) between Valentinus and the Valentinians see: Christoph Markschies, Valentinus Gnosticus? Untersuchungen zur Valentinianischen Gnosis mit einem Kommentar zu den Fragmenten Valentinus (Tübigen: Mohr-Siebeck, 1992).
} 
comprise three main sections. First, in AH 1.1-9 Irenaeus examines the doctrines of Ptolemean Valentinianism, especially their cosmology and cosmogony. Second, in AH 1.10-22 he contrasts the diversity of the heretics' systems with the unity of the teaching of the church. Finally, in AH 1.23-31.2 he identifies the origins and ancestry of Valentinianism. ${ }^{7}$ While Irenaeus' catalog of the heretics is clearly dependent upon earlier sources, his summary of Valentinianism and related streams is the oldest surviving catalog. ${ }^{8}$

In AH 1 Irenaeus presents the Gnostic reading of Gen 1-3 that in many ways mirrors the scriptural networking we find in AH 2-5. ${ }^{9}$ However, the Gnostics are evidently less concerned with the intertextual connections between scriptural passages than with the harmonization of scripture to their various mythological systems. Gerard Luttikhuizen observes this tendency saying, "[t]he intertextual tension between the biblical texts and their Gnostic interpretations betrays that on essential points the thought structure of the interpreters differed from what they found in these texts." 10 Thus, while the early chapters of Genesis were essential to Gnostic interpretation, they did not hesitate to correct or amend Moses when he deviated from their own theological traditions and more recent revelation. ${ }^{11}$

Beginning with $A H$ 1, Irenaeus describes how Gnostic intertextuality unites the texts of Gen 1-3 with a variety of scriptural accounts and extra-biblical material. The style of these intertextual connections may be framed within a set of conceptual categories including: catchwords or verbal connections, gematria, prosopological interpretation, and a literal or "plain sense" reading of Gen 1-3. For the Gnostic, Moses' presentation is inherently suspect because he wrote before the full revelation of knowledge given in Christ. The Gnostics, therefore, carefully conformed Moses to more recent revelation. ${ }^{12}$ In addition to the Gnostic perspective on Gen 1-3, Irenaeus provides a few instances of his own intertextuality and theological reasoning that begins to characterize his reading of scripture. From our analysis, the Gnostic textual networking with Gen 1-3 competes with Irenaeus'

\footnotetext{
${ }^{7}$ SC $264.28-152$.

${ }^{8}$ Thomassen, The Spiritual Seed, 9; cf. AH 1.pf.2; 1.13.3; 1.15.6; 3.17.4; 4.pf.2.

${ }^{9} \mathrm{BP}$ notes a reference to Gen 1:26 in $A H$ 1.15.3, Gen 3:1 in $A H$ 1.30.14, and Gen 3:18 in $A H$ 1.24.2, but these echoes were not definitive enough for consideration.

${ }^{10}$ Luttikhuizen, Gnostic Revisions, 5. Friedrich Weiss, Frühes Christentum und Gnosis: Eine rezeptionsgeschichtliche Studie (Tübingen: Mohr-Siebeck, 2008), 500.

${ }^{11}$ Pheme Perkins, "Gnosticism and the Christian Bible," in The Canon Debate, ed. L. M. McDonald and J. A. Sanders, 355-71 (Peabody, MA: Hendrickson, 2002), 370.

${ }^{12}$ Giverson, "The Apocryphon of John," 75-6; Holsinger-Friesen, Irenaeus, 61, 101-3.
} 
intertextual interpretation of these creation passages, even though the textual networks they create are theologically distinct.

\subsection{AH 1.5.1-6: Valentinians on Creation (Gen 2:5, Gen 2:7, Gen 3:21)}

In $A H$ 1.1-3.6, the Bishop of Lyon characterizes the plan and nature of the Pleroma and the primordial defection of Sophia. ${ }^{13}$ For the Valentinian these protological matters are necessary prolegomena for any proper reading of Gen $1-3{ }^{14}$ The fall of Sophia recorded in AH 1.2-3 is the crucial event that casts a shadow of ignorance over the subsequent cosmological activities. ${ }^{15}$ Sophia errs, according to Irenaeus, by attempting to comprehend the greatness of the perfect Father. ${ }^{16}$ She also does so apart from the union with her cohort. As a result, she gives birth to an object that bears the nature of her own "ignorance, grief, fear, and bewilderment" (ignorantia et taedio et timore et stupore).$^{17}$ The outcome of Sophia's passion is the creation of the Demiurge and the embodiment of ignorance in all materiality. The demiurgic ignorance is, for Irenaeus, the "cardinal objection" to Valentinian cosmology and, more specifically, their reading of Gen $1-3 .^{18}$

In $A H$ 1.5.1-4 Irenaeus describes the Valentinian formation of the world. The Gnostic account of the creation of the world, according to Irenaeus, is enacted through the cooperation of Achamoth and the Demiurge, though the Demiurge was ignorant of Achamoth's assistance. ${ }^{19}$ This is why after creating all things, the Demiurge proudly admires his creation and makes the ignorant proclamation of Isa 45:5, "I am God and besides me there is no one" (Ego Deus, et praeter me nemo). ${ }^{20}$ The

\footnotetext{
${ }^{13}$ For a representation of this system see: Thomassen, Spiritual Seed, 195-96. Thomassen divides Valentinian pleromatology into two primary camps distinguished by the "detail" they ascribe to the personal names of the pleromic aeons and their relationship to the initial existence of the Father. Irenaeus falls into the group that ascribes more specificity to the aeons and theorizes about the thirty aeons coupled in syzygic pairs. Ibid., 193-6.

${ }^{14}$ On the debate over the reliability of Irenaeus' presentation see: Pagels, "Conflicting Versions of Valentinian Eschatology: Irenaeus' Treatise vs. Excerpts from Theodotus," HTR 67 (1974): 35-53. Holsinger-Friesen, Irenaeus, 43-50.

${ }^{15}$ Hellenistic Jewish sources, such as Philo, never cast the Creator as ignorant. Steenberg, Irenaeus, 30.

${ }^{16}$ Many have pointed to parallels with Gnostic texts such as: Apocryphon of John, On the Origin of the World, and the Hypostasis of the Archons.

${ }^{17} \mathrm{AH}$ 1.2.3.

${ }^{18}$ Steenberg, Irenaeus, 24 . The scope of this study is only concerned with the scriptural references to Gen 1-3 in Irenaeus' presentation of Gnosis. For an evaluation of the performance of Gen 1-3 in the Gnostic literature see: L. Painchaud, "The Use of Scripture in Gnostic Literature," JECS 4.2 (1996): 12946; S. Giverson, "The Apocryphon of John and Genesis," StuTh 17 (1963): 60-76; Luttikhuizen, Gnostic Revisions, 17-81.

${ }^{19} \mathrm{AH}$ 1.5.3.

${ }^{20} \mathrm{AH}$ 1.5.4.
} 
ignorance of the Demiurge infuses the creation accounts with the language of Isa 45:5. ${ }^{21}$ The Valentinian account of creation contains, however, no explicit allusion to Gen 1-3. Some language and images bear a resemblance to the creation accounts, such as the attributes of "heavenly" (caelestia) and "earthly" (terrena) (cf. 1 Cor 15:48), but there is no substantive reference to Gen 1-3.

In $A H$ 1.5.5-6, Irenaeus transitions from a description of Valentinian cosmology and cosmogony to anthropology. ${ }^{22}$ The Valentinians read the narrative of the formation from the dust in Gen 2:7 in light of the language of the "earthly element" (choicum) drawn from 1 Cor 15:47. For the Valentinians Adam was not made from the "dry earth" (arida terra, Gen 2:5), but "from the invisible substance and from fusible and fluid matter" (ab inuisibili substantia et ab effusibili et fluida materia). ${ }^{23}$ The distinction is, as Dunning rightly observes, substantial in nature and not a rejection of materiality altogether..$^{24}$ In other words, the Valentinians, according to Irenaeus, observe the wrong substance of creation and prefer the Pauline imagery to the Mosaic substance. ${ }^{25}$ In this manner, the language of "earthly" (choicum) comes to interpret the creation from the dust in Gen 2:7, rather then the substance of the dry earth that God forms in Gen 2:5. The limited use of Genesis also suggests a degree of separation from any dependence upon the Mosaic for the Gnostic understanding of cosmology. They are not relying upon Gen 1-2 for an accurate description of the formation of the human person.

The Valentinians, Irenaeus reports, argue that the Demiurge breathed into this creature the "psychic element" (psychicum), so that the first creature is composed of an earthly (Gen 2:7a) and psychic element (Gen 2:7b). They also separate the terms "image and likeness" (imaginem et similitudinem) and apply them to these two elements of the first-created man. The material or "earthly" (choicum) element was created after the "image" (imaginem), while the "psychic" (psychicum) element was after the "likeness" (similitudinem) ${ }^{26}$ The former is also said to come

\footnotetext{
${ }^{21}$ Steenberg, Irenaeus, 25-6; cf. AH 2.5.3.

${ }^{22}$ Holsinger-Friesen compares the Valentinian account with Plato's Timaeus. Holsinger-Friesen, Irenaeus, 90-92.

${ }^{23} \mathrm{AH}$ 1.5.5. Although this allusion is not noted in BP or SC, the reference to "dry earth" (arida terra) in refers to Gen 2:5 prior to God watering the earth in Gen 2:6. cf. Epid 32; AH 3.18.7; AH 4.39.2.

${ }^{24}$ Benjamin H. Dunning, "Virgin Earth, Virgin Birth: Creation, Sexual Difference, and Recapitulation in Irenaeus of Lyons," JofR, 89.1 (2009): 57-88, 70.

${ }^{25}$ Holsinger-Friesen is aware that the Valentinians read 1 Cor 15:47 alongside Gen 2:7, but neglects Irenaeus' contextual argument from the dry earth of Gen 2:5. Irenaeus and Genesis, 89-90.

${ }^{26} \mathrm{AH} 1.5 .5$.
} 
near to God because it was after the image of God, but it is not of the same substance as the pneumatic element. The psychic element was also termed the "Spirit of life" (spiritum vitae, Gen 2:7), because it derived from a "spiritual emission" (spiritali defluitione). ${ }^{27}$ The final stage in the formation of humankind is completed when the creature is clothed in a "skin-like garment" (dermatinam tunicam, Gen 3:21) that becomes the sensory fleshy substance. ${ }^{28}$ In this arrangement, the formation of the flesh occurs after the act of disobedience. In AH 1.5.6 Irenaeus provides further background to the Valentinian creation of humankind. Unbeknownst to the Demiurge, Achamoth deposits the true "spiritual man" (spiritalis homo) while the Demiurge is breathing in the breath of life (Gen 2:7), or the psychic element. This spiritual deposit is planted as a seed into the soul of the creature and functions as a spiritual womb. ${ }^{29}$ In time the spirit seed will grow and become the receptor of the "perfect Knowledge" (perfectae Rationis). ${ }^{30}$ The action of Achamoth completes the fourfold elements of humanity where the first man has "his soul is from Demiurge, his body is from the earth, his fleshy element is from matter, and his spiritual element is from his Mother Achamoth" (animam quidem a Demiurgo, corpus autem a limo, et carneum a material, spiritalem uero hominem a matre Achamoth).$^{31}$ Clearly each of these four elements that constitute the Valentinian creation of Adam derived from a conflation of the imagery resident in Gen 1:26, Gen 2:7, Gen 3:21, 1 Cor 15:47 but infused with the images and characters of the Valentinian myth.

\subsection{AH 1.9.3: The Word and the Flesh (Gen 2:7)}

Having laid the basis of the Valentinian myth, in AH 1.8-9 Irenaeus addresses specific exegetical and hermeneutical issues with the Valentinian misappropriation of scripture. Using the example of the Mosaic and Homeric cento (alongside other simple polemical illustrations) he argues that the Valentinians abuse the scriptures because they consistently "adapt" (aptare) them to the structure of their myth. ${ }^{32}$ As an example, Irenaeus points to the opening chapter of John's Gospel arguing, contra the Valentinians, John never intended to reveal the Ogdoad of the Valentinian

\footnotetext{
${ }^{27} \mathrm{AH} 1.5 .5$.

${ }^{28}$ AH 1.5.5. Holsinger-Friesen, Irenaeus, 88-9.

${ }^{29}$ Holsinger-Friesen points to the middle-platonic background of this view. Holsinger-Friesen, Irenaeus, 83.

${ }^{30}$ AH 1.5.6.

${ }^{31}$ AH 1.5.6.

${ }^{32}$ AH 1.8.1-2.
} 
cosmological system. John, he suggests, preached one God and one Christ Jesus, the Word of God who became flesh (John 1:14).$^{33}$ The Valentinians deny the Word become flesh, because the Savior assumed a psychic body, which became visible and palpable through an unspeakable mystery. In order to define the nature of "flesh" (caro) in John 1:14, Irenaeus reads John 1:14 in continuity with the formation of Adam from the dust in Gen 2:7. ${ }^{34}$ This is to say $\sigma \alpha \rho \xi$ is identified with the limus in Gen 2:7. The flesh the Word assumed in John 1:14 is the same "ancient handiwork made by God out of the earth as in Adam" (vetus de limo secundum Adam facta plasmatio a Deo). ${ }^{35} \mathrm{He}$ even goes so far as to suggest this intertextual connection is John's intention by which John aimed to dismantle their first and principal Ogdoad. What is more, he identifies all the individual aeons comprising the Valentinian Ogdoad (Word, Only begotten, Life, Light, Savior, Christ, Son of God) as the one and same Son of God who became incarnate in the person of Christ. This essential link between Gen 2:7 and John 1:14 in Irenaeus' exegesis will resurface throughout AH 35.

\subsection{AH 1.14.6: Marcus and the Sixth Day (Gen 1:31)}

In $A H$ 1.13-20, Irenaeus refutes Marcus and the Marcosians who have an acute fascination for gematria and put forth an adapted version of the Valentinian myth. ${ }^{36}$ Gematria is the practice of interpreting a word based upon the numeric value of its letters. ${ }^{37}$ AH 1.14.1-4 describes the narrative of revelation Marcus received from the Tetrad who descended in the form of a woman and revealed to him the origin and meaning of all things. The revelation is confirmed though various kinds of numerology and allegorization that envision an ontological congruence between "being" and "truth" in the form of speech, so that "what is spoken is at the same time that which it speaks about." 38 This offers a philosophical grounding for the numerical representation of divine realities within the text. In $A H$ 1.14.6, Irenaeus recounts a series of passages they unite through the symbolism of the number six.

\footnotetext{
${ }^{33}$ AH 1.9.1.

${ }^{34} \mathrm{AH} 1.9 .3$

${ }^{35}$ AH 1.9.3.

${ }^{36}$ Ismo Dunderberg, "The School of Valentinus," in A Companion to Second-Century Christian 'Heretics,' eds. Antti Marjanen and Petri Loumanen, 64-99 (Leiden: Brill, 2005), 82; Grant, Gnosticism and the Early Church (New York: Columbia University Press, 1966), 64; Thomassen, The Spiritual Seed, 499.

${ }^{37}$ B. Ehrman, The New Testament: A Historical Introduction to the Early Christian Writings, (Oxford: Oxford University Press, 2000), 387, 454.

${ }^{38}$ Thomassen, The Spiritual Seed, 243.
} 
Matt 17:1 describes the transfiguration on the "sixth day" (sexta die) when Jesus took Peter, James, and John up to the mountain and after Moses and Elijah appeared the number of those present at the transfiguration also totaled six. In John 19:14 Jesus prepared for the Passover at the "sixth hour" (sextam horam) and he also suffered death on the cross in Matt 27:45 at the "sixth hour" (sextam horam). ${ }^{39}$ of course, this numerological conflation also includes mention of Moses' report that humankind was made on the "sixth day" (sexta die), echoing the creation of Adam in Gen 1:31. The day of Adam's creation on the sixth day is not interpreted literally, but simply participates in Marcus' number symbolism as a means to validate his aeonic system.

\subsection{AH 1.18.1-4: The Marcosians on Creation (Gen 1:2, Gen 1:3-27, Gen 1:26, Gen 2:10)}

In $A H$ 1.18.1-4 Irenaeus details the Marcosian theory of the creation. According to Irenaeus, they assert the mother of the Demiurge used him as an instrument and, in continuity with Middle-Platonic metaphysics, created the visible world after the pattern of invisible beings. To validate their cosmology, the Marcosians utilize complex sets of passages bound by common numerological references to typify the Tetrad, Decad, Deodecad, and Triacontad. Irenaeus characterizes this method of exegesis as progressive and evolving, saying that they "transpose and adapt" (transformantes coaptant) the writings from the prophets as they continually amend their myth. ${ }^{40}$

Beginning in $A H$ 1.18.1, Irenaeus reports that the Marcosians find a type of the Tetrad in Gen 1:1 with the four terms: "God and Beginning, the heavens and the earth" (Deum et principium, caelum et terram). ${ }^{41} \mathrm{~A}$ second Tetrad, which is an offspring of the first, is found in the terms of Gen 1:2: “deep" (abyssum), "darkness” (tenebras), "water" (aquae), and "Spirit" (Spiritus). ${ }^{42}$ Gen 1:2 also discloses the "invisible" (invisibile) nature of the Tetrad through Moses' description of the unformed earth. In $A H$ 1.18.2, the Tetrad is found in the formation of the sun on the fourth day in Gen 1:14-19, the colors of the curtains of the tabernacle in Exod 26:1/38:6, and the four rows of stones on the priestly robe in Exod 28:17. He identifies the same kind of numerology in Gen 1:3-12 that records the Decad in the ten terms: light, the day, the

\footnotetext{
${ }^{39} \mathrm{cf.}$. Lk 15:33.

${ }^{40} \mathrm{AH}$ 1.18.1. Steenberg, Irenaeus, 27; Dunderberg, "The School of Valentinus," 83.

${ }^{41} \mathrm{cf}$. "Beginning" in AH 1.14.1

${ }^{42} \mathrm{AH}$ 1.18.1.
} 
night, the firmament, the evening, the morning, the dry land, the sea, the plants, and the trees. ${ }^{43}$ Similarly, Gen 1:14-27 records the Dodecad including: the sun, moon, stars, seasons, years, sea monsters, fishes, reptiles, fowl, quadrupeds, beasts, and humans. ${ }^{44}$ The whole of Gen 1:1-27, therefore, speaks of the cohort of thirty aeons known as the Triacontad. ${ }^{45}$

The same numerology applies to the formation of humankind and the various components that comprise the human anatomy. The human person is created in the "image of the Power on high" (imaginem superioris Virtutis), echoing Gen 1:26. ${ }^{46}$ The human form possesses one fountain in the brain out of which flows "four powers" (virtutes IIII), echoing to the rivers flowing from Eden in Gen 2:10. These powers numerologically reflect the Tetrad, as do the four senses of sight, sound, hearing, and taste. ${ }^{47}$ The Ogdoad is also witnessed in two ears, two eyes, two nostrils and double sense of taste (that is bitter and sweet). The Decad is found in the ten fingers, and the Dodecad in the twelve members of the body, which together represent the Triacontad. The intertextual relationship between these texts is again located in their associations and their unified representation of the Tricontad. ${ }^{48}$ Irenaeus suggests these passages are merely exemplary of their gematria. He reports a series of other passages they use in continuity with these numerical representations including: Gen 6-50, Exod 24-36, Josh 3-4, 1 Sam 9:22, 1 Sam 20:1-42, 2 Sam 23:13, 1 Kgs 11:21, 1 Kgs 18:31, 1 Pet 3:20 and John 20:24. Any passage reflecting the number eight represents the Ogdoad, ten the Decad, twelve the Dodecad, and thirty the Triacontad. ${ }^{49}$

In the same context the Bishop of Lyon summarizes the complex Marcosian understanding of human formation. He reports that most argue Adam was formed on the eighth day, representing the Ogdoad, but some distinguish between the "earthly" (choicum, 1 Cor 15:47) part that was formed on the sixth day from the

\footnotetext{
${ }^{43}$ AH 1.18.2.

${ }^{44}$ AH 1.18.2.

${ }^{45}$ Apart from this context an implicit echo in $A H$ 5.30.4, Irenaeus never mentions any passage from Gen 1:6-25, which is remarkable given Theophilus' detailed analysis of this portion. For an explanation of Theophilus' understanding of creation see Steenberg, Irenaeus, 88-92.

${ }^{46}$ AH 1.18.2.

${ }^{47}$ They ignore the fifth sense of touch.

${ }^{48} \mathrm{AH}$ 1.18.1. In addition, according to Irenaeus, the identification of this system is based upon a concept of inspiration where the Spirit of these realities communicates through Moses.

${ }^{49}$ AH 1.18.3-4
} 
"fleshy" (carnalem) part that was formed on the eighth day. ${ }^{50}$ The former reflects the earthly part formed in Gen 2:7, while the latter is the covering of sensible skin given in Gen 3:21. ${ }^{51}$ This anthropological distinction understands the formation of the flesh to come after the disobedience in Gen 3. Other Marcosians, Irenaeus informs us, partition the creation of Adam into two individual accounts, where the spiritual man was made bisexual after the image and likeness (Gen 1:26) and the earthly man was formed from the earth (Gen 2:7). This distinction implies that some Marcosians view Gen 1:26 and Gen 2:7 as successive stages in the formation of Adam, while others understand them as two distinct accounts forming distinct human persons. ${ }^{52}$ The Marcosians intertextual practice is inherently numerological and theological as they attempt to reconcile the scriptural account of creation with their own myth.

\subsection{AH 1.22.1: Creation and The Regula Veritatis (Gen 1:1, Gen 2:7)}

AH 1.22.1 is a highly significant section, principally due to it discussion of the regula veritatis/fidei, which he previously mentioned in $A H 1.10 .1 .^{53}$ His theology of creation is an essential prolegomena for the theological structure of the regula that forms the prelude to the divine activity throughout the scriptures. His description of the regula comprises echoes to the creation of the world in Gen 1:1 and the formation of Adam in Gen 2:7 alongside a host of intertexts including: Hermas, Mand 1.1, Psalm 32:6, John 1:3, Col 1:16, 2 Cor 4:18, Exod 3:6 ${ }^{54}$, and Eph 1:3.

The regula commences with reference to creatio ex nihilo where he represents God as the Creator of "all things" (omnia). In a general-to-particular style of argumentation, the meaning of "all things" (omnia), he reasons, must include both the world and humankind. He begins with citations of the Shepherd of Hermas, Mand 1.1 and John 1:3, but then interprets these passage with Gen 1:26, Gen 2:7, Psalm 32:6, and Col 1:16. Noormann understands the concept of creation by means of the Word as the linking feature for these texts, which is generally correct. But the more precise linking concept is the creation and administration of "all things"

\footnotetext{
${ }^{50} \mathrm{AH} 1.18 .2$

${ }^{51}$ cf. AH 1.5.5-6. Cf. Gen 1:31.

${ }^{52}$ This discussion of "day" (die) of Adam's formation is addressed at several points especially AH

5.33.2-3, where Irenaeus comments on the "day" (die) Adam and Eve sinned in Gen 2:16-17 and Gen 3:6. Steenberg, Irenaeus, 84-87.

${ }^{53}$ While the regula is arguably more prominent in $A H 1.10 .1$, we have not included a discussion of $A H$

1.10.1, because it does not contain any discernable allusion or echo to Gen 1-3.

${ }^{54}$ Matt 22:29-32.
} 
(omnia) ${ }^{55}$ Irenaeus wants to prove that God the Father by means of the Word created all existing realities and continues to sustain them throughout their existence. In support of Mand 1.1 and John 1:3, he fashions a narratival framework linking the Creator of the world (Gen 1:1) and humanity (Gen 2:7) with the Father of Abraham (Exod 3:6) and the Father of Jesus (Eph 1:3). Together these passages identify God the Father of Abraham and Christ as the Creator of the both world and humankind, thus demonstrating the same God who has given all things existence in Gen 1:1 and Gen 2:7 administered over all of salvation history from Abraham to Christ. He also argues that God did not have any assistance in the formation and preservation of creation other than God's own Son and Spirit. Naturally, this implies a "foundational paradigm" or "hypothesis" where God the Creator creates as a triunity of Father, Son, and Sprit. ${ }^{56}$ This theological paradigm, however, is what draws together the texts of Gen 1:1, Gen 2:7, Psalm 32:6, John 1:3, and Col 1:16. While we cannot deny the importance of John 1:3, clearly Steenberg overstates the case when he asserts "no single verse of the New Testament writing is of stronger influence on Irenaeus' cosmological considerations than John 1:3," because Irenaeus does not treat John 1:3 in isolation. ${ }^{57}$ Instead, we find here and elsewhere that John $1: 3$ is the essential passage for detailing the creation of all things only within a network of texts that speak the divine human relationship. Moving forward from creation by means of the Word in Mand 1:1, John 1:3, Gen 1:1, and Gen 2:7, God continues to be active in Israel's history. The same God who created all things is also the God of Abraham (Exod 3:6) and Father of Jesus (Eph 1:3).

\subsection{AH 1.24.1-2: Saturninus on Creation (Gen 1:26, Gen 2:7, Gen 3:19)}

In this section, Irenaeus recounts the views of Saturninus on the origin and formation of humankind, who followed a system similar to that of Menander. ${ }^{58}$ Irenaeus' presents his cosmological views as an unmistakable revision of Gen 1-3, which correlates Gen 1:26, Gen 2:7, and Gen 3:19 with additional background narratives..$^{59}$ According to Irenaeus, Saturninus casts the unknown Father as the

\footnotetext{
${ }^{55}$ Noormann, Irenäus, 85.

${ }^{56}$ Steenberg, Irenaeus, 67.

${ }^{57}$ Steenberg, Irenaeus, 69. Epid 43, 1.8.5, 1.9.2, 2.2.5, 3.8.2-3.

${ }^{58}$ C. Markschies, Gnosis: an Introduction (New York: T\&T Clark, 2003), 77.

${ }^{59} \mathrm{BP}$ suggests that death here refers to the command in Gen 2:17, but clearly the nature of the allusion has the description of the dissolution of the flesh in Gen 3:19 in view.
} 
Creator of all spiritual realities, but the world and human beings were created by the work of seven angels. ${ }^{60}$ These angels witness a certain "shining image" (lucida imagine, $c f$. Gen 1:26) from the sovereign Power above, they are unable to possess the image so they proclaim to one another, "Let us make man after our image and likeness" (Faciamus hominem as imaginem et similitudinem, Gen 1:26). ${ }^{61}$ The angels, however, were not strong enough to create a true, living form so the newly fashioned man could only wiggle along the ground like a worm. Seeing the flaccid creature floundering on the ground, the supreme Power has pity on him because "he was made in his likeness" (in similitudiem eius factus esset, Gen 1:26). The supreme Power responds by emitting a "spark of life" (scintillam vitae, Gen 2:7) that immediately enlivens the man and enables him to stand erect. After death the same body fashioned by the angels separates again and decomposes back into the earth (Gen 3:19), so this spark of life can return to its proper spiritual home. We also find in AH 1.24.2 these angels created both "wicked" (nequam) and "good" (bonum) humans. The good are the faithful ascetics who retain the spark of life, while the wicked are those marry and beget children. The Savior who appeared as a man came to rescue those who are good and destroy the God of the Jews. ${ }^{62}$ Irenaeus closes the general observation regarding Saturninus' prosopological application of old Testament prophecy. Every prophecy, including the portions of Gen 1:26 and Gen 2:7 mentioned previously, are spoken from the perspective of the Angelic creators, Satan the Angel who opposes them, or the God of the Jews.

\subsection{AH 1.28.1: Asceticism in Tatian and the Encratites (Gen 1:27-8)}

In $A H$ 1.28.1 Irenaeus mentions a few descendents of the Gnostics sects previously mentioned, including Tatian and the Encratites. He has consistently admitted the challenge of illustrating the systems and doctrines of the various Gnostic sects because of their fluidity and inventive nature. ${ }^{63}$ New factions are constantly evolving and inventing new systems that are "patched together" (compegerint) from the tenets of their forbearers. His present examples are the teachings of the

\footnotetext{
${ }^{60}$ Apparently Saturninus is aware of Meander's unknown Father (AH 1.23.5), whom he links to Simon Mangus. The summary of Basilidies (AH 1.24.3-5), on the other hand, does not allude to particular passage in Gen 1-3.

${ }^{61}$ The angelic mediation in creation is attested to in a verity of Gnostic texts such as the Apocryphon of John and On Origin of the World.

${ }^{62}$ Markschies, Gnosis, 78.

${ }^{63} \mathrm{cf}$. AH 1.21.5; AH 1.28.2; AH 1.29.1.
} 
Encratites and Tatian, who reject marriage, abstain from meat, and deny Adam's salvation. ${ }^{64}$ From this analysis, there appears to have been various forms of Encratism known to Irenaeus. ${ }^{65}$ Allegedly they developed their beliefs from Marcion, Cerdo, and Saturinus, whom he also reports had their rise from Simon, and their ascetical perspective reflects an anti-corporeal dualism. While he does not present their particular reading of Gen 1:27-28, according to Irenaeus, Tatian and the Encratites' ascetic position misrepresents the purpose of the propagation of the human race reflected in the creation of male and female (Gen 1:27). They have also rejected the implication that God created all things for humankind to enjoy (Gen 1:28). This also echoes God's handing over all things to humankind in Gen 1:28. According to Irenaeus, this ascetic position renders the Encratites ungrateful towards God's gift of creation and God's purposes in creation. Tatian, Irenaeus reports, follows this same teaching, but couples these ascetic views with a revised Valentinian myth and the denial of Adam's salvation. He addresses Tatian's views on Adam in more detail in AH 3.23.1-8, but for now he is clear this is Tatian's own invention. ${ }^{66}$

\subsection{AH 1.30.1-9: The Ophites on Creation (Gen 1:2, Gen 1:7-8, Gen 1:26, Gen 2:7, Gen 2:16, Gen 2:22, Gen 3:1-7, Gen 3:20, Gen 3:23)}

In $A H$ 1.30.1-15 Irenaeus concludes $A H 1$ with a description of the tenets of the Ophites, who boast many similarities to the Valentinians mentioned in AH 1.1-7. ${ }^{67}$ Much of AH 1.30.1-9 recounts the events of the primeval world and provides a revisionist account of Gen 1-3. ${ }^{68}$ The importance of Gen 1-3 in AH 1.30.1-9 is unmistakable. The Ophites imagine a cosmology that conforms the imagery of Gen 1-3 to the variety of spiritual realities. Although the allusions to Gen 1-3 conclude with $A H$ 1.30.9, the remaining chapters ( $A H$ 1.30.10-14) frame Gen 1-3 within a larger recounting of the whole Ophite history of salvation. ${ }^{69}$

\footnotetext{
${ }^{64} c f$. Col 2:16. See also Basilides on food AH 1.24.5.

${ }^{65}$ William L. Petersen, "Tatian the Assyrian," in A Companion to Second-Century Christian 'Heretics', eds Antti Marjanen and Petri Luomanen (Leiden: Brill, 2005), 143.

${ }^{66}$ Petersen shows the seedbed of this thought present in Tatian's writings. Petersen, "Tatian the Assyrian," 150-52.

${ }^{67}$ On the relationship of the Ophites and Valentinians see Bentley Layton, The Gnostic Scriptures (Garden City, NY: Doubleday, 1995) 170; Kurt Rudolph, Gnosis: The Nature and History of Gnosticism (Edinburgh, T\&T Clark, 1983), 308-326; Holsinger-Friesen, Irenaeus, 51-56.

${ }^{68}$ Holsinger-Friesen, Irenaeus, 58.

${ }^{69}$ For Sethian Gnosticism in general, John Turner has shown that Sethian works "de-temporalized" time into an eternal present where salvation is a self-actualized, ever present reality. John D. Turner,
} 
Irenaeus' account of the Ophites begins with a description of Bythus, who is the "Father of all things" (Patrem omnium) or the "First-Man" (Primum Hominem). ${ }^{70}$ Bythus emitted the "Second-man" (Secundum Hominem) or "Son of Man" (Filium Hominis) and below these existed the Spirit, who is also called the "First-Woman" (Primam Feminam). ${ }^{71}$ Following the style of gematria we have seen in other accounts, this Spirit was found hovering over the four elements of Gen 1:2: "water, darkness, abyss, and chaos" (aquam, tenebras, abyssum, chaos). ${ }^{72}$ Then the First-Woman is wedded to the First-Man and the Son of man and they gave birth to Christ and Sophia, so they refer to the woman as the "Mother of the living" (Matrem uiuentium, Gen 3:20). ${ }^{73}$ Christ is caught up to the upper regions where he joins with the Father, Son and, Mother to be the true and holy Church, while Sophia descends into the waters and disturbs them. From this action she assumes the substance of a fluid body that imprisoned her divine light (Gen 1:2). She regretted this body and, being infused by her moisture of light, she was lifted up, having spread herself out she becomes the visible heavens (Gen 1:7-8) ${ }^{74}$ Her son, Jaldabaoth, also drew upon the waters of Gen 1:2 and emitted a succession of seven sons in the "imitation of his Father" (secundum patris imitationem, Gen 1:26) and these sons are the "Angels, Archangels, Virtues, Powers, and Dominions" (Angelos et Archangelos et Virtutes et Dominationes, Eph 1:21) that rule of heavenly and earthly things. ${ }^{75}$

The sons with Jaldabaoth sit in heaven according to their birth rank and together they rule over all "the heavenly and earthly things." (caelestia et terrestria, Gen 1:1). ${ }^{76}$ However, Jaldabaoth became distressed because his sons quarreled amongst themselves over the their individual ranks. In his sadness he fixed his desire upon the material substance so that a son called Mind is born. This Mind twisted himself into the form of a serpent and begot all "forgetfulness, wickedness, jealousy, envy, and death" (obliuionem et malitiam et zelum et inuidiam et mortem). ${ }^{77}$

\footnotetext{
"Time and History in Sethian Gnosticism," in For the Children, Perfect Instruction, ed. H. G. Bethge, et al., 203-14 (Leiden: Brill, 2002), 213.

${ }^{70} \mathrm{AH} 1.30 .1$.

${ }^{71}$ AH 1.30.1.

${ }^{72}$ AH 1.30.1. Holsinger-Friesen notes the connections with the Apoc John. Holsinger-Friesen, Irenaeus, 60n.70. See also Giverson, "The Apocryphon of John."

${ }^{73} \mathrm{AH} 1.30 .2$.

${ }^{74}$ AH 1.30.3.

${ }^{75} \mathrm{AH}$ 1.30.4-5. In the same context he also cites similar terminology including: "Heavens, Virtues, Powers, Angels, and Creators," (Caelos et Areothas et Virtutes et Angelos et Conditores).

${ }^{76} \mathrm{AH} 1.30 .5$.

${ }^{77} \mathrm{AH} 1.30 .6$.
} 
This is the same serpent that upset the Father, Jaldabaoth, with his wickedness in heaven and paradise (Gen 3:1-6). Then in the presence of the other Angels and his Mother, Jaldabaoth proclaimed his preeminence with the words of Isa 45:5/46:9, "I am the Father and God, and there is no one above me" (Ego Pater et Deus, et super me nemo). ${ }^{78}$ When Jaldabaoth's Mother hears this scandalous proclamation, she retorts, "Do not lie, Jaldabaoth, for there is above you the Father of all things, who is FirstMan, and so is that Man who is the Son of Man" (Noli mentiri, Ialdabaoth, est enim super te Pater omnium Primus Anthropus, et Anthropus Silius Anthropi). ${ }^{79}$ Since the angels did not know of the Mother's existence, her voice frightened them and they began questioning the source of the voice. Unaffected by the voice, Jaldabaoth corralled his rulers with the charge of Gen 1:26, "Come, let us make man to the image" (Vienite, faciamus hominem ad imaginem).$^{80}$ Hearing of Jaldabaoth's plan, the Mother seized this opportunity and gave the six other angels an idea of the human form so that through the man she could deprive them of their power. ${ }^{81}$

Borrowing loosely from the imagery of Gen 2:7, the cohort of angels assembled the man that was immense in breadth and length. The man, however, could not manage to stand erect and only wriggled across the ground. ${ }^{82}$ So the Angels brought him before Jaldabaoth, who enacts the imagery of Gen 2:7 and breathes into the man the "spirit of life" (spiritum uitae). ${ }^{83}$ But the Mother arranged this plan in order that when Jaldabaoth breathed into the man, he unknowingly surrendered his power. After receiving the breath of Jaldabaoth, the newly created man came alive. At once the enlivened man gave thanks to the First-Man and rejected Jaldabaoth his Maker. ${ }^{84}$ Disturbed by the loss of his power Jaldabaoth, borrowing from Gen 2:22, created a woman from his own thought in order to deceive the man and take back his power. But no sooner was she created than Sophia deprived her of her power by means of the serpent, when she transgressed

\footnotetext{
${ }^{78} \mathrm{AH} 1.30 .6$. See also the use of Is $45: 5 / 46: 9$ by the Demiurge in $A H 1.5 .4$ and the Barbelo-Gnostics in AH 1.29.4.

${ }^{79} \mathrm{AH} 1.30 .6$.

${ }^{80} \mathrm{AH}$ 1.30.6. On the tradition of angelic mediation and the interpretation of Gen 1:26 and Gen 2:7 see Jarl Fossum, "Gen. 1,26 and 2,7 in Judiasm, Samaritanism and Gnosticism," JSJ 16.2 (1985): 203-39.

${ }^{81}$ AH 1.30.6.

${ }^{82} \mathrm{AH} 1.24 .1-2$

${ }^{83} \mathrm{AH}$ 1.30.6. Cf. Irenaeus speaks of a worm-like man in Saturnius and Basilides in AH 1.24.1.

${ }^{84} \mathrm{AH} 1.30 .6$.
} 
the prohibition of Gen 2:16 and ate from the tree of Knowledge. ${ }^{85}$ What is more, the sons of Jaldabaoth came to admire her beauty and "called her Eve" (uocasse eam Euam, Gen 3:20) and beget sons with the woman (Gen 6:2). ${ }^{86}$ This series of blunders continues to portray the incompetence of the Creator God to manage his own creation and the astuteness of Sophia to recover the power from Jaldabaoth. ${ }^{87}$

According to Irenaeus, the Ophites interpret the temptation account of Gen 3:1-6 follows the text more closely than any previous account. Sophia, working through the serpent, leads Adam and Eve "to transgress the precept of Jaldabaoth" (supergredi praeceptum Ialdabaoth, Gen 2:17). ${ }^{88}$ Through their disobedience they received the "knowledge of that Power which is above all things" (cognouisse eam quae est super omnia Virtutem, Gen 3:7) and in doing so rejected their Maker. ${ }^{89}$ With this knowledge, the lie Jaldabaoth uttered when he called himself Father of all (Isa 45:5) was exposed and the Fall reflects Sophia's triumph over a malevolent God. ${ }^{90}$ In the closing lines of $A H 1.30 .15$, Irenaeus reports one variation on this account saying that some of the Ophites identify Sophia as the serpent. In this rendering the serpent implanted Adam and Eve with the true knowledge and, as a result, is considered wiser than all others (Gen 3:1). ${ }^{91}$

In $A H$ 1.30.8-9, Irenaeus reports Jaldabaoth threw Adam and Eve out of paradise and into the world because they had transgressed his command (Gen 3:23). ${ }^{92}$ In fact the whole account of creation transpires in the heavenly realm. ${ }^{93}$ Likewise, the serpent was cast into the world and generated six sons, who are the seven devils of the world that oppose humankind. When Adam and Eve were in paradise they had spiritual bodies, but through their transfer into this present world they became encumbered by their physical bodies. Even their souls, according to Irenaeus, were languid because they only had the "mundane breath" (insufflationem mundialem, Gen 2:7) from their Maker. ${ }^{94}$ Prounikos sees Adam and Eve

\footnotetext{
${ }^{85}$ Holsinger-Freisen, Irenaeus, 66. She is said to send Prounikos the meaning of which is disputed. See SC 264.303; Dominic Unger and John Dillon, St. Irenaeus against Heresies (New York: The Newman Press, 1992), 260; Layton, The Gnostic Scriptures, 174.

${ }^{86}$ AH 1.30.7.

${ }^{87}$ Holsinger-Friesen, Irenaeus, 67-8.

${ }^{88} \mathrm{AH}$ 1.30.7. In $A H$ 1.30.5. the Serpent is the nous of Jaldabaoth's son.

${ }^{89} \mathrm{AH} 1.30 .7$.

${ }^{90}$ Holsinger-Friesen, Irenaeus, 72.

${ }^{91} \mathrm{AH} 1.30 .15$.

${ }^{92}$ AH 1.30.8.

${ }^{93}$ Holsinger-Friesen, Irenaeus, 64.

${ }^{94}$ AH 1.30.9.
} 
in this sluggish and feeble state and has pity upon them. Acting in the in the manner of Gen 3:7, he enlivened them, causing them to realize they were naked and weighed down by a material body. ${ }^{95}$ In their wisdom, though, they knew this would be only for a short time.

In $A H$ 1.30.9 Irenaeus continues discussing Gen 4 and the birth of Abel along with details of how the serpent used Cain to slay his brother Abel, and in AH 1.30.1014 he mentions Noah, Abraham, Moses, and the Prophets before moving into commentary on Jesus traditions. Eventually the First-Man sends Christ to aid his sister Sophia and announce the unknown Father. ${ }^{96}$ This summary demonstrates a theological narrative that links scriptural texts to descriptions of the primordial world to Jesus traditions. The Mosaic account of creation is not normative for the Ophites as they order and rearrange texts to suit their theological preferences. ${ }^{97}$ They do not, however, follow the narratival or chronological trajectory of the Genesis account as presented. Instead, through various styles of intertextuality they carefully reconstruct the narratives in order to fashion a separate account that conforms select scriptural texts to their own mythical system.

\subsection{Conclusion}

While we will reserve a comprehensive conclusion for the final chapter, we have seen in AH 1 how the Gnostics, including the Valentinians, Marconians, Saturnius, Encratites, Tatian, and the Ophites, all make use of narratives and imagery peculiar to Gen 1-3. The imagery and terminology in Gen 1-3 has particular explanatory power for their system. They are not concerned with clarifying the revelation contained within Moses; instead they adapt, transpose, or divide passages in order to elucidate their own distinctive cosmology and cosmogony. As a result, Irenaeus' presentation of the Gnostic reading of Gen 1-3 exposes a diverse set of intertextual reading practices including: catchwords or verbal connections, gemetria, prosopological interpretation, and a literal or "plain sense" reading of Gen 1-3. In addition, Irenaeus provides a few instances of his own theological reading of Gen 13.

\footnotetext{
${ }^{95} \mathrm{AH} 1.30 .9$.

${ }^{96} \mathrm{AH} 1.30 .12$.

${ }^{97}$ Holsinger-Friesen, Irenaeus, 62.
} 
First of all, the Gnostics use catchwords or linking terms to blend Gen 1-3 with other texts. This practice, however, is not widespread since the Gnostics are more interested in conforming their narrative to the mythological systems outside of scripture, rather then simply harmonizing the scriptural narrative within itself. To begin with, his presentation of Ptolemean Valentinianism cosmogony and cosmology rarely alludes to Gen 1-3 in any explicit fashion ( $A H$ 1.5.1-4), but their account of the formation of Adam does draw from Genesis creation texts. In doing so, they use the descriptive language of "earthly" (choicum)," drawn from 1 Cor 15:47, to explain the substance of the man fashioned in Genesis, rather than the plain sense reading of "dust" (limus) or "earth" (terra) in Gen 2:5-7. In AH 1.18.2, the Marcosians provide a similar intertextual use of 1 Cor 15:47 in connection to the formation of Adam on the sixth day in Gen 2:7, but they also add that his "fleshy" (carnalem) part was formed on the eighth day in Gen 3:21.

Second, similar to practice of linking terms, the Gnostics use gemetria to knit together various texts with equivalent numerological representations. In AH 1.14.6 Marcus links the "sixth" (sexta) day of creation in Gen 1:31 with other uses of the number six in Matt 17:1, Matt 27:45, and John 19:14. In the same way, the Marcosians in AH 1.18.1-2 link together groupings of four, ten, twelve, and thirty found throughout Gen 1:1-27 that represent the various Pleromic cohorts of aeons. This type of reading ignores the immediate context of the passages and the larger narratival framework of the Genesis texts, preferring instead to focus exclusively upon the numbers or quantities represented in a given passage.

Third, the Gnostics employ a type of prosopological interpretation whereby they identify different persons in the Genesis narratives with figures in their own mythical system..$^{98}$ In $A H$ 1.24.1-2, Irenaeus identifies the speakers and characters acting in Gen 1:26 and Gen 2:7 with the Demiurge and his angelic servants. A similar reading is found among the Ophites in AH 1.30.1-9. They identify Jaldabaoth and his angelic sons as the divine beings working in the creation of Adam in Gen 1:26, Gen

\footnotetext{
${ }^{98}$ For further discussion of elarly Christian "prosopological" interpretation see: M. Slusser, "The Exegetical Roots of Trinitarian Theology," TS 49 (1988) 461-476; C. Andresen, "Zur Entstehung und Geschichte des trinitarischen Personbegriffes," ZNW 52 (1961) 1-39; M.-J. Rondeau, Les commentateurs patristiques du Psautier (IIIe-Ve siècls), 2 vols. (Rome: Oriental Institute, 1982, 1985). Andresen uses the term "prosopographic exegesis" as a method of listing or cataloging the speaker(s) in a text, but Rondeau and slusser agree that "prosopological exegesis" more clearly explains this early Christian method of exegesis, because this term implies the process of identifiying the speakers in a text. Slusser, "Exegetical Roots," 462-63.
} 
2:7, Gen 2:17, Gen 2:22, Gen 3:1-6, Gen 3:7, and Gen 3:20. They also appeal to the divine proclamation of Isa 45:5/46:9, and the angelic imagery of Eph 1:21 to describe the deprave nature and character of these divine beings.

Fourth, amid these other intertextual reading strategies, the Gnostics provide a type of "plain sense" interpretion of Gen 1-3, where they read Genesis texts within their original context as a narrative of creation. However, even though they read these texts as a coherent narrative, they conform the original narrative and consistently reorder the events of Gen 1-3 according to the nature of their myth. From the Gnostic perspective the problem is that Moses wrote before the full revelation of knowledge given in Christ, so his account must be carefully amended where he does not conform to the Gnostic doctrines. ${ }^{99}$ For Irenaeus, the resolution for artificial scriptural networking is found only in the proper ordering and correspondence of scripture ( $A H$ 1.8.1, $A H$ 1.9.4).

In addition to the Gnostic perspective on Gen 1-3, in $A H$ 1.9.3 and $A H$ 1.22.1 Irenaeus provides instances of his own theological intertextuality that characterizes his reading of scripture in subsequent books. Like the Gnostics, he uses linking terms and catchwords to unify passages. In $A H$ 1.9.3, he links the imagery of "flesh" (caro) in reference to Christ's incarnation in John 1:14 with the substance of Adam's formation in Gen 2:7. Irenaeus even suggests that this was John's original intention in the composition of his prologue. In AH 1.22.1, the term "all things" (omnia) theologically binds together Psalm 32:6 LXX, John 1:3, Col 1:16, and Mand 1.1. He also follows a general-to-particular argument and contrasts the particular creation of humankind in Gen 1:26 and Gen 2:7. ${ }^{100}$ Finally, he begins to show his prosopological interpretation when he identifies the Creator in Genesis with the "Father" (Pater) of Abraham mentioned in Exod 3:6 and the "Father" (Pater) of Jesus mentioned in Eph $1: 3$, as the same Creator and Father who created all things by means of the Word (John 1:3). This style of intertextual networking becomes more prevalent in subsequent books as Irenaeus develops his polemical response to Gnosis.

\footnotetext{
${ }^{99}$ Giverson, "The Apocryphon of John," 75-6; Holsinger-Friesen, Irenaeus, 61, 101-3; Grant, Irenaeus, 25.

${ }^{100}$ For comparison of a similar type of argumentation in Justin see: W.A. Shotwell, The Biblical Exegesis of Justin Martyr (London: SPCK, 1965), 32-33.
} 


\section{CHAPTER 3: THE INTERTEXTUAL RECEPTION OF GENESIS 1-3 BOOK 2 OF ADVERSUS HAERESES}

\subsection{Introduction}

Whereas $A H 1$ was concerned with exposing the various Gnostic systems, AH 2 seeks to refute them on crucial points of doctrine. ${ }^{1}$ He assures his reader that he will not argue all possible objections, but only those that are particularly damaging to the Valentinian system. Irenaeus believes this rhetorical strategy will expose the contradictions in their theological perspective and refute their essential arguments. He is acutely concerned with the passages they draw out from the scriptures and adapt to their own theological framework. ${ }^{2}$ Therefore, in light with his own regula and scriptural interpretation, in $\mathrm{AH} 2$ he endeavors to undermine the crucial theological pillars of the Valentinian cosmological system.

The argument of $A H 2$ is divisible into five sections: $A H$ 2.1-11, $A H$ 2.12-19, $A H$ 2.20-28, AH 2.29-30, and AH 2.31-35. ${ }^{3}$ AH 2.1-11 evaluates the Valentinian distinction between the Creator-God and the Pleroma. AH 2.12-19 addresses the nature of the aeons and the salvation of the pneumatic seed. AH 2.20-28 deals with issues of numerology in the Valentinian (and related) systems. AH 2.29-30 appraises the Valentinian consummation and the Demiurge, and AH 2.31-35 responds to those who have followed the Valentinian traditions. Within this structure the uses of Gen 1-3 are reserved to one opening section ( $A H$ 2.2.5) and three latter sections $(A H$ 2.26.1, $A H$ 2.30.7,9, and $A H$ 2.34.4). It is not surprising that we find allusions to Gen 13 in the opening and closing sections; Irenaeus has a tendency to frame his work with allusions to Gen 1-3. ${ }^{4}$

The textual networking in $A H 2$ extends Irenaeus' intertextual reading of Gen 1-3 that we observed in AH 1. The manner of Irenaeus' intertextual exegesis in AH 2 may be framed within a set of conceptual categories including: narratival connections, linking terms, prosopological interpretations, and theological harmonization of texts. In a general sense, Irenaeus assumes God as Creator is an epistemological grounding for his theological framework and argumentation, and in

\footnotetext{
${ }^{1}$ AH 2.pf.2.

${ }^{2}$ AH 2.pf.1.

${ }^{3}$ SC 293:119-20.

${ }^{4}$ References to Gen 1-2 are found in Epid 11 and 97 and the closing paragraph of $A H$ 5.36.3.
} 
order to understand the work of God in creation Irenaeus argues specifically for the necessity to read Moses in continuity with rest of apostolic testimony.

\subsection{AH 2.2.5: God's Unmediated Creation (Gen 1:1, Gen 1:3 ${ }^{5}$ )}

The section of $A H$ 2.1-11 engages the nature of the Demiurge and the origin of creation. Irenaeus begins arguing for what he considers the most essential premise of reality: "God the Creator, who made the heaven and the earth, and all things that are therein" (Demiurgo Deo, qui fecit caelum et terram et omnia quae in eis sunt, Gen 1:1). ${ }^{6}$ He did so, Irenaeus adds, without any external assistance or influence. God is completely self-sufficient and capable of accomplishing all creative acts. ${ }^{7}$ While the Gnostics argue that angels, or some other kind of mediary, formed the world, Irenaeus suggests God needed no "other instruments" (aliis organis) for the creation of all things. ${ }^{8}$ The Word was a "suitable and sufficient" (idoneus... et sufficiens) means to accomplish creation. As we found in $A H$ 1.22.1, John 1:3 is read in concert with the creation accounts. He interprets the preposition $\delta 1 \alpha$ in John 1:3 as instrumental and emphasizes the inclusiveness of "all things" (omnia). The present world must be contained, Irenaeus argues, within the sphere of "all things" which necessitates that the world too was created by means of the Word. This is evidenced with the various uses of $\varepsilon i \pi \varepsilon v$ in Gen 1:3. ${ }^{9}$ For Irenaeus, the instrumentality of the Word in creation expressed in John 1:3 is the means to understand God speaking creation into existence in Gen 1:3. Irenaeus also defends his theological reading of Gen 1:3 with Psalm 32:9/148:5 (LXX) that reports God spoke creation into existence. This unites the testimonies of the prophets and apostle, so that the continuity of John 1:3, Gen

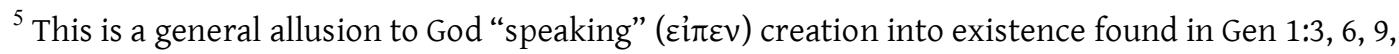
etc. In $A H$ 4.32.1, Irenaeus explicitly cites Gen 1:3 for the same purpose. Steenberg, states that $A H$ 4.32.1 is the "only quotation" of Gen 1:3, which technically is correct. However, the present section alludes to this passage generally and the purpose of citing Gen 1:3 in $A H 4.32 .1$ and $A H$ 2.2.5 is the same. Steenberg, Irenaeus, 70.

${ }^{6}$ AH 2.1.1

${ }^{7}$ God's unmediated creation of all things is a theme to which Irenaeus frequently returns: $A H$ 1.22.1, AH 2.2.1-5; AH 4.7.4; AH 4.41.1. MacKenzie, Irenaeus's Demonstration, 81-99. Steenberg frames Irenaeus' arguments against angelic mediation into three categories, all of which are present in AH 2.2.1-5: angelic mediation suggests angels may act in opposition of God's will, God creates angels and establishes their function, and God needs no aid in creation given the presence of the Son and the Spirit. Steenberg, Irenaeus, 76 n. 46.

${ }^{8} \mathrm{AH}$ 2.2.1, 5. There is also the related issue of the developing Jewish apocalypticism that emphasized angelically mediated creation exemplified in Philo. Bilde, "Gnosticism, Jewish Apocalypticism, and Early Christianity," in the last days: On Jewish and Christian Apocalyptic and its period, eds. Jeppesen, et al., (Aarhus: Arhus University Press, 1994): 9-32, 22.

${ }^{9} C f$. Gen 1:6, Gen 1:9, etc...
} 
1:3, and Psalm 32:9/148:5 LXX all express the same reality of God creating all things by means of the Word.

After making these theological arguments, Irenaeus raises the question of authority that challenges the very basis of the Gnostic appeal to the Mosaic account. Arguing for the authoritative continuity between the apostle and prophet, he poses the rhetorical question:

Whom, therefore, shall we believe as to the creation of the world, these heretics who have been mentioned that prate so foolishly and inconsistently on the subject, or the disciples of the Lord, and Moses, who was both a faithful servant of God and a prophet? [Heb 3:5]. He at first narrated the formation of the world in these words: 'In the beginning God created the heaven and earth,' [Gen 1:1] and all other things in succession. ${ }^{10}$

Of course, the rhetorical question implies that Moses accurately recorded the creation of all things by means of the Word beginning with Gen 1:1. Following the sentiment of the author of Hebrews, Irenaeus views Moses and his writings as authoritative and envisions Moses a faithful servant of God and a prophet. He pits the authority of Moses' account of creation in continuity with the "disciples of the Lord" (discipulis Domini) against the Gnostic revisions of Moses. While the apostles and Moses are consistent, the doctrines of the heretics and Moses are inconsistent. In other words, the true account of creation is the ordered narratival account of creation recorded in Gen 1:1ff that is affirmed and illuminated by the apostolic testimony, rather than the Gnostic revisions of Genesis. Irenaeus is in effect asking his readers to choose between these two systems of interpretation and to affirm the authority of the Mosaic account in continuity with the teaching of the apostles.

\subsection{AH 2.26.1: Knowledge and Love (Gen 2:7)}

In $A H$ 2.26.1, Irenaeus discusses the knowledge of God and its limits appealing to 1 Cor 8:1, "Knowledge puffs up but love edifies" (Scientia inflat caritas autem aedificat). ${ }^{11}$ He asserts it is better to be simple and be close to God than learned and found among the Gnostics. Paul, Irenaeus remarks, did not believe that knowledge of God was injurious but simply false knowledge of God that denies a love for God and

\footnotetext{
${ }^{10} \mathrm{AH}$ 2.2.5. Cui igitur magis credemus de mundi fabricatione, hisne qui praedicti sunt haereticis sic fatua et at inconstantia garrientibus, an discipulis Domini et fideli famulo Dei Moysi et prophetae? Qui et primo genesim mundi enarrauit, dicens: In principio Deus fecit caelum et terram, et deince Psalm reliqua omnia.

${ }^{11} \mathrm{AH} 2.26 .1$.
} 
esteems the individual as perfect. ${ }^{12}$ This false knowledge is contrary to the fundamental nature of the Creator-creature relationship established in creation of humankind in Gen 2:7. ${ }^{13}$ For Irenaeus the greatest offence of the Gnostics is rejecting the very one who fashioned humankind and infused them with the breath of life (Gen 2:7), because they imagine themselves more perfect than the God who created them.

Challenging the speculative tendencies of the Gnostics, he charges they are not content with knowing that God created all things, but concern themselves with limitless theories on why God created. ${ }^{14}$ Alluding to the love between the Father and the Son in John 15:9-10, he suggests it would be more profitable to have no knowledge of God's motivation for creation and to love God anyway than to be puffed up with false knowledge of speculative matters. For Irenaeus the faithful should seek after no other knowledge except Jesus Christ, the Son of God, crucified for the salvation of God's people (1 Cor 2:2). ${ }^{15}$ Therefore, Irenaeus reads 1 Cor 8:1, John 15:9-10 and 1 Cor 2:2 in continuity with Gen 2:7, assuming knowledge of the crucified Son will direct the faithful toward a more profound love for God and bring them into submission to the God who formed humankind in Gen 2:7.

\subsection{AH 2.28.1: Creation and Providence (Gen 1:1, Gen 2:7, Gen 1:28)}

This section continues the same line of argumentation reflected in AH 2.26.1. Irenaeus begins by reminding the reader that the church has in their midst both the regula veritas/fidei and the testimony about God in the scriptures as the guide to the true knowledge of God. ${ }^{16}$ The Gnostics, Irenaeus argues, seek out unattainable knowledge with sundry answers to vexing questions that direct them away from true knowledge of God and abandon any love of God. Instead of seeking out unattainable knowledge, the faithful should content themselves with the revelation of God that is "clearly" (aperto) proclaimed (cf. AH 2.28.3). This "clear" proclamation combines a set of interlocking allusions and echoes depicting God's economic

\footnotetext{
${ }^{12}$ AH 2.26.1.

${ }^{13}$ AH 2.26.1.

${ }^{14}$ William R. Schoedel, “Theological Method in Irenaeus (Adversus haereses 2.25-28)," JThS 35 (1984): 31-49; W. C. van Unnik, "Theological Speculation and its Limits," In Early Christian Literature and the Classical Tradition, In Honorem Robert M. Grant, Théologie historique 53 (Paris: Beauchesne, 1979): 33-43. ${ }^{15}$ AH 2.26.1.

${ }^{16}$ AH 2.28.1.
} 
activity throughout salvation history including: Gen 1:1, Gen 2:7, Gen 1:28, Heb 7:7, Job 3:16, and Matt 3:12. ${ }^{17}$

His economic report describes God as the Creator of the world (Gen 1:1), the Creator of humankind (Gen 2:7), and humankind as infused with the "faculty of increase" (donauit incrementum), echoing Gen 1:28 characterizing the progressive sanctification of God's creature. ${ }^{18}$ He supports the sanctification of the faithful with an echo of Heb 7:7, depicting a movement from the lesser to the greater in the advancement toward divine perfection. He also links the theme of progression in Heb 7:7 to the images of childbirth in Job 3:16 and harvesting in Matt 3:12. The former is the transition from the formation in the womb to birth, while the latter is the imagery of planting and harvesting. The intertextual link between these texts is the imagery of creation and increase, with the will of God governing both. In this way, the passages of Gen 1:1, Gen 2:7 and Gen 1:28 are linked through a narratival framework from the creation of the cosmos and humankind to the advancement of humankind toward perfection exemplified in Job 3:16, Matt 3:12, and Heb 7:7.

\subsection{AH 2.30.7: Paul's Rapture to Paradise (Gen 1:1, Gen 2:7, Gen 2:15)}

The larger section of AH 2.29-30 concerns the nature of salvation in Valentinian thought and summarizes the eternal destiny of the three substances: hylics, psychics, and pneumatics. The hylics remain below and are destroyed, the psychics ascend only to the intermediary place, and the pneumatics ascend to the Pleroma. Fundamentally Irenaeus argues if pneumatics are saved by their nature, the notion of a Savior is superfluous. What is more, the description of Paul's ascension to the third heaven in 2 Cor 12:4 appears central to the Valentinian account of salvation, whereas Irenaeus demonstrates how Paul's ascension is not incongruous with the salvation of the body.

In AH 2.30.7, Irenaeus cites Paul's rapture to Paradise in 2 Cor 12:4 and critiques the Valentinian emphasis on the spiritual nature. While he challenges the Valentinian interpretation of Paul's ascension, he observes that Paul's physical body in 2 Cor 12:2-3 did not hinder Paul's ability to witness spiritual visions. In his analysis of Paul's rapture in 2 Cor 12:4, Irenaeus describes the "spiritual mysteries"

\footnotetext{
${ }^{17}$ AH 2.28.1.

${ }^{18}$ AH 2.28.1.
} 
(sacramenta... spiritalia) that Paul witnessed as the "operations of God" (Dei operationes) and those who reach the height of perfection, such as Paul, may also become "spectators" (speculatores) of the work of God. He illustrates these spiritual mysteries or "operations of God" with a series of allusions to Gen 1-2 that recount how God "made the heavens and the earth [Gen 1:1], and formed man [Gen 2:7], and placed him in paradise [Gen 2:15]" (fecit cealos et terram et plasmauit hominem et posuit in paradiso). ${ }^{19}$ The language of "paradise" (paradisus) links Gen 2:15 and 2 Cor 12:2-4, but Irenaeus extends this connection with a narratival summary of the creation of the world and Adam and his placement in Paradise (Gen 2:15). ${ }^{20}$ In paradise Adam became a "spectator" (speculator) of these works of God, but now those like Paul who come to exceed in their love of God will invert Adam's expulsion from paradise and become spectators of God in paradise, beholding the divine activity revealed there. This implies that what Paul observed in paradise was the true knowledge of God as Creator.

\subsection{AH 2.30.9: Creation by the Word and Wisdom (Gen 1:1, Gen 2:7, Gen 2:8)}

In AH 2.30.9 Irenaeus continues the same line of argumentation and believes he has sufficiently proven that the "spiritual" Valentinians are not superior to the Creator. This chapter comprises an extended reflection on the nature of God and God's economic activity, including: Gen 1:1, Gen 2:7, Gen 2:8, Eph 1:21, Matt 11:27, Heb 1:3, and Mand. $1 .^{21}$ He restates his basic premise that God created all things by means of the Word and Wisdom, which he defends with an allusion to Heb 1:3, where God created all things by the "Word of His power" (Verbo uirtutis suae). ${ }^{22}$ He conflates Heb 1:3 with Hermas Mand. 1 in order to unify the "Word" (Verbo) and the "Wisdom" (Sapientia) in the creative process. Irenaeus believes the Will and Wisdom of God form all things from his own substance. ${ }^{23}$ He also provides an allusion to Col 1:16 with the language of God creating all things including things "visible" (visibilia) and

\footnotetext{
${ }^{19}$ AH 2.30.7. cf. Gen 2:8.

${ }^{20}$ There is an implied use of Gen 3:8 in the description of the Lord walking in the garden.

${ }^{21} \mathrm{AH}$ 2.30.9. He also mentioned an assortment general scriptural titles or terminology such as "heaven and earth, and the seas, and all things that are in them" (Exod 20:11, Psalm 145:6, Acts 4:24, 14, 15, and Matt 22:32) and "Father of our Lord Jesus" which is a standard Pauline introductory formula (2 Cor 1:3, 11:31, Eph 1:3, 3:14, Col 1:3, and 1 Pet 1:3). Many of the statement are general scriptural images and titles mingled together with allusions to other scriptural texts and descriptions of God.

${ }^{22}$ AH 2.30.9.

${ }^{23}$ Fantino, La Théologie, 311-12; cf. AH 2.10.4, 2.14.4.
} 
"invisible" (invisibilia), as well as Gen 1:1 in the language "heavenly" (caelestia) and the "earthly" (terrena). ${ }^{24}$ These texts, for Irenaeus, depict the Word as the instrument of the Father or, in Steenberg's more formal definition, the "formative actualization of the Father's creative will." ${ }^{\text {25 }}$ While these discussions often precipitate in the context of Gen 1:26, here we see the conflation of Heb 1:3 and Mand. 1 framed against the notion of a mediated creation.

This Creator, according to Irenaeus, is above every "Principality, and Power, and Dominion, and Virtue" (Principalitatem et Potestatem et Dominationem et Virtutem, Eph 1:21) and the same God has wrought creation and salvation. ${ }^{26}$ Irenaeus frames the activity of God with a punctuated narratival account of salvation history. He begins with the act of creation of the world by means of the Word and Wisdom (Psalm 145:6 LXX ${ }^{27}$ ) and joins this with an allusion to the formation of Adam in Gen 2:7, the formation of paradise in Gen 2:8, the Noahic account in Gen 6, and then alludes to the God of Abraham, Isaac, and Jacob (Matt 22:32). He rounds off the summary with a general allusion to the law, the prophets, the revelation in Christ, the apostles, and the church. ${ }^{28}$ Linking the Creator with the Father of Jesus (2 Cor $1: 3^{29}$ ) and the Son as the revealer of the Father (Matt 11:27) with the summary of salvation history suggests the Son has been revealing the Creator and Father since the beginning. The events of salvation history do not merely anticipate the incarnation of the Son, but include the revelatory activity of the Son.

\subsection{AH 2.34.3-4: Formation and Progression of Body and Soul (Gen 2:1, Gen 2:7)}

This section is essential for discerning the nature of the soul's relation to the body in Irenaeus' thought. ${ }^{30}$ His evaluation considers the nature of the soul with respect to the "breath of life" (aspiratio vitae) in Gen 2:7. In the closing lines of the preceding section, he has already depicted the resurrected life as the union of the body, soul,

\footnotetext{
${ }^{24}$ AH 2.30.9.

${ }^{25}$ Steenberg, Irenaeus, 79-80. Steenberg's language of "actualization" may be problematic if he implies the Word as the end product of God's creative will rather than the means. Orbe, "San Ireneo y la Creación de la material," Greg 59 (1978): 71-127, 74-75.

${ }^{26}$ AH 2.30 .9

${ }^{27}$ cf. Exod 20:11, Acts 4:24, and Acts 14:15.

${ }^{28}$ AH 2.30 .9

${ }^{29}$ cf. 2 Cor 11:31, Eph 1:3, Eph 3:14, Col 1:3, and 1 Pet 1:3.

${ }^{30} \mathrm{cf}$. Epid 15. Justin, Dial 5.
} 
and Spirit. ${ }^{31}$ As a result, he carefully distinguishes between the soul and the body, as well as the animation of the soul, or the "breath of life," and the Spirit. Behr rightly argues that Irenaeus is not interested in delineating the nature of the soul per se; this speculation is reserved for the Gnostics. ${ }^{32}$ However, the Gnostics argue that if God created the soul it necessarily would be subject to death and decay like the rest of creation. Irenaeus denies the transmigration of the soul and argues that souls are immortal, even though they had a beginning. ${ }^{33}$ God the immortal and eternal Creator, according to Irenaeus, sustains and preserves all creation from beginning to end. In AH 2.34.1 he defends this view from the healing of Lazarus, arguing that God preserved the soul's existence after death. He even suggests that the soul continues in the same form as it had in the body, which Steenberg terms the "human-shaped soul," and remembers the deeds performed in the body. ${ }^{34}$ In $A H$ 2.34.2 Irenaeus' basic response is that all of God's creation is inherently subjected to the will of the Creator and develops this point in AH 2.34.3-4 with the aid of Gen 2:1, Gen 2:7, Psalm 148:5-6/32:9 LXX, Psalm 20:5 LXX, and Luke 16:10.

In the opening lines of $A H$ 2.34.3, Irenaeus alludes to the completion of creation in Gen 2:1 and argues that just as the creation has existed for a long duration of time, so also the soul. He connects this point with Psalm 148:5-6/32:9 LXX, where he finds the qualitative description that God has created all things to exist "forever" (in saeculum). ${ }^{35}$ While creation had a beginning, it is prepared to exist eternally. The same point is made in reference to humankind in Psalm 20:5 LXX. The "life" (vitae) God bestowed upon humanity through salvation prepares the faithful to exist "forever" (in saeculum). ${ }^{36}$ Echoing the imagery of Gen 2:7, life is not something that originates naturally within humanity, but is given by the grace of God. ${ }^{37}$ The description of Adam becoming a "living soul" (animam vivam, Gen 2:7) confirms that the soul is enlivened only through participation with life imparted

\footnotetext{
${ }^{31}$ AH 2.33.5. cf. AH 5.3.3.

${ }^{32}$ Behr, Asceticism, 94; AH 1.5.5-6; AH 1.30.8-9; AH 2.34.3-4; AH 4.pf.4; AH 5.6.1. He does argue that the soul is eternal in $A H$ 5.7.1-2.

${ }^{33}$ Ibid., 92.

${ }^{34}$ Steenberg, Irenaeus, 127. Scholars have debated the "corporeal" nature of Irenaeus' view of the soul. Ibid., 130.

${ }^{35}$ AH 2.34.3.

${ }^{36}$ AH 2.34.3. Rousseau interprets "life" (vitae) in Psalm 20:5 as the "life in the Spirit" Adam enjoyed prior to his disobedience, but Behr rightly notes that "life" is this section must be life in the body. Behr, Asceticism, 94-6. SC 293, 345-6. Rousseau's position was also criticized heavily by Lassiat. Lassiat, “L' Anthropologie d'Irénée," NRT 100 (1978) 399-417, 405.

${ }^{37}$ AH 2.34.3. cf. AH 1.18.1-2, AH 3.21.10, AH 5.12.2-6
} 
from God. ${ }^{38}$ For Irenaeus, the "soul" (anima) and "life" (vitae) are separate existences. Under the provision of the divine will, God bestowed life upon the soul and gave it both "life and perpetual duration" (uitam et perpetuam perseuerantiam). ${ }^{39}$ To be sure, as Behr argues, the pre- and post-lapsarian life of Adam are "different modalities of life" that prefigure the eschatological divine life. ${ }^{40}$ Those who reject God or are ungrateful, like the shrewd manager in Luke 16:10, are separated from the will of God and not granted eternal life, because the life given by the breath is temporal. $^{41}$

\subsection{Conclusion}

As we have seen, the nature of Irenaeus' textual networking in AH 2 extends the intertextual practices observed in $A H 1$. Although all the allusions to Gen 1-3 are intentionally polemical, they continue to provide insight into his own intertextual logic. First, what is unique to AH 2 is Irenaeus' specific call to read the Mosaic account of creation in continuity with the apostolic testimony (AH 2.2.5). He asserts that Moses is a more trusted authority (Heb 3:5) on creation of all things than the Gnostic intellectuals who continually revise or amend Genesis in accordance with their own theological perspective.

Second, he frames several references to Gen 1-3 in a narratival or chronological arrangement in accordance with salvation history. In AH 2.30.7, Irenaeus interprets the "spiritual mysteries" (sacramenta... spiritalia) that Paul witnessed while raptured to Paradise in 2 Cor 12:4 as the "operations of God" (Dei operationes). He defines these operations as the creative acts of God in Gen 1:1, Gen 2:7, and Gen 2:15. Similarly, in AH 2.30.9 Irenaeus continues his discussion of the nature of God and God's economic activity using Gen 2:7 and Gen 2:8 to frame certain events of salvation history and allusions to Noahic, Abraham, Isaac, Jacob, the Law, Prophets, and Christ.

Third, he continues to bind texts together through linking terms and

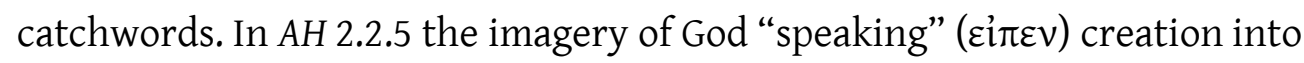

\footnotetext{
${ }^{38}$ AH 2.34.4.

${ }^{39}$ AH 2.34.4.

${ }^{40}$ Behr, Asceticism, 95.

${ }^{41}$ cf. AH 5.3.3.
} 
existence in Gen 1:3, ${ }^{42}$ corresponds with God speaking in Psalm 32:9 ${ }^{43}$ LXX, and God creating my means of the Word in John 1:3. In AH 2.30.7, the language of "Paradise" (paradisus) links 2 Cor 12:4 with God placing Adam in paradise in Gen 2:15. While Adam was expelled from Paradise for his disobedience, Paul is raptured to paradise. Finally, in AH 2.34.3-4, the language of "life" (vitae) and "forever" (saeculum) links Gen 2:7, Psalm 32:9LXX, Psalm 20:5 LXX, and Luke 16:10.

Fourth, there are prosopological readings of Gen 1-3 where Irenaeus identifies the divine persons active in the creation accounts. In AH 2.2.5 Irenaeus assumes the act of creation involves not only the Father, but also the Word of God (John 1:3). Then, in AH 2.30.9, he conflates a reference to Word of God (Heb 1:3) with the Wisdom of God in Mand 1 to prove the activity of the Word and Wisdom in the act of creation.

Fifth, there are also general conceptual or theological connections that are not necessarily linked through specific verbal relationships. It is common for these connections to have some Christological influence that results in a theologically symbiotic relationship between these Genesis passages and other scriptural references. In AH 2.26.1, Irenaeus discusses the knowledge of God and its limits with the intertextual use of Gen 1:26, Gen 2:7, 1 Cor 8:1, John 15:9-10, and 1 Cor 2:2. He claims his opponents reflect the puffed up knowledge of 1 Cor 8:1 that is contradictory of the Creator-creature relationship established in Gen 1-2. The knowledge of God as the Creator of all things is an epistemological foundation for his theological framework. This, according to Irenaeus, is the most essential and clear revelation available to all, and in AH 2.28.1 Irenaeus suggests the faithful should content themselves with this clear revelation of God. He further describes this revelation with a set of intertextual references including: Gen 1:1, Gen 1:26/2:7, Gen 1:28, Heb 7:7, Job 3:16, and Matt 3:12. These texts are connected through imagery that envisions a progressive sanctification moving from creation toward perfection in the divine likeness. Finally, in AH 2.34.3-4 Irenaeus address the basic anthropological connection between the soul and the body through the harmonization of Gen 2:7, Psalm 32:9 LXX, Psalm 20:5 LXX, and Luke 16:10. He argues the soul does not have life naturally but partakes of life from God, since God

\footnotetext{
${ }^{42}$ Gen 1:3, 6, 9, etc.

${ }^{43}$ Psalm 148:5.
} 
creates all things, the perpetual existence of creation is dependent upon the will of the Creator.

These intertextual strategies become even more prevalent in $\mathrm{AH}$ 3-5, as Irenaeus' intertextual reading of Gen 1-3 serves his theological polemic. In these books, Irenaeus moves from exposing and refuting the Gnostic theological system to expounding his own theological perspective. 


\section{CHAPTER 4: THE INTERTEXTUAL RECEPTION OF GENESIS 1-3 IN BOOK 3 OF ADVERSUS HAERESES}

\subsection{Introduction}

Having examined the use of this pericope in Irenaeus' ancient milieu in AH 1-2, this third book presents a pivotal turning point in his refutation of the Gnostics. He shifts his polemical tactics from exposing and refuting doctrines of the Gnostics in AH 1-2 to defending and explaining the apostolic faith in light of scripture and tradition in AH 3-5. AH 3 demonstrates the continuity, contra the Gnostics, in the activity of God from creation to incarnation, and throughout his argument Irenaeus keeps his focus on the person and work of Christ.

As a whole the book may be framed into four major sections: AH 3.1-5, AH 3.6-15, AH 3.16-23, and AH 3.24-25. ${ }^{1}$ In $A H 3.1-5$ he contrasts the teaching of the heretics with the authoritative teaching of the Apostles, supported by a theory of apostolic succession in the church. In AH 3.6-15 he argues for the existence of one God, who is both Creator of all things and Father of Jesus Christ. In AH 3.16-23 he contends, against the Valentinians, Ebionites, and Tatian, that there is only one incarnate Son of God who recapitulates all things. Finally, in AH 3.24-25 he closes the book with a plea for the heretics to return to the teaching of the church, which is the true locus of the Spirit. Therefore, the general thrust of the whole book argues for the "one God Creator of the heaven and earth" (unum Deum Factorem caeli et terrae) and "one Christ the Son of God (unum Christum Filium Dei)."2 These claims impose a theological pressure upon Irenaeus' interpretation of scripture and determine the performance of Gen 1-3 in the context of his theological exegesis.

Similar to what we witnessed in AH 1-2, although a few references to Gen 1-3 surface in the early part of the work, the latter chapters contain a concentration of echoes, allusions, and citations. ${ }^{3}$ This is not surprising given the emphasis on incarnation and recapitulation that is directed by a Pauline Adam-Christ typology in the latter portion of the AH 3. These Christological references are found within

\footnotetext{
${ }^{1}$ SC 210:171-205.

${ }^{2} \mathrm{AH}$ 3.1.2.

${ }^{3}$ AH 3.3.3; 3.11.5, 8; 3.18.1, 7 ; 3.19.3; 3.20.1; 3.21.10; 3.22.1-4; 3.23.1-8; 3.24.1-2. There are several allusions that we could not confirm including: Gen 1:1 in AH 3.15.3, Gen 2:16-17, Gen 3:6, Gen 3:15 and Gen 3:19 in AH 3.20.2, and Gen 3:22 in AH 3.21.4. All of these echoes were too general for the present discussion.
} 
networks of texts that support the activity of one God and Father administering creation by means of the Son. His theological and Christological argumentation culminates in $A H$ 3.23.1-8 that is organized in a chiastic structure around the contents of Gen 3. His exegesis continues to use a variety of intertextual strategies including: narratival and structural arrangements, catchwords, theological or typological relationships, prosopological interpretations, and illustrative application of texts. These reading strategies provide a conceptual framework for his intertextual networking of scripture.

\subsection{AH 3.3.3: The Narrative of Salvation (Gen 1:1, Gen 2:7)}

In AH 3.3.2-3 Irenaeus mentions a letter written by Clement from the church at Rome to the church at Corinth. ${ }^{4}$ He considers this letter, commonly known as 1Clement, more authoritative since it predates the Gnostic teachers. Irenaeus reports this letter urged the church at Corinth to declare the tradition received from the apostles, which he qualifies with a telescoped summary of salvation history including: creation of the world, creation of humankind, the Flood, the Exodus, the giving of the law, the prophets and the judgment of Satan. ${ }^{5}$ These events correspond to a set of observable scriptural allusions and echoes including: Gen 1:1, Gen 2:7, Gen 6:17, Gen 12:1, Exod 3:10, Exod 3:4, Ex 20:1, Isa 6:8, Matt 25:41. ${ }^{6}$ This narratival arrangement draws predominately from the Old Testament; and God as the Creator of the world in Gen 1:1 and the creation of Adam in Gen 2:7 provide the contents of the initial sequences. ${ }^{7}$ The latter portion of the arrangement makes a dramatic transition from the prophets to the eschatological judgment of Satan in

\footnotetext{
${ }^{4}$ AH 3.3.3. Irenaeus' succession list includes Linus and Anacletus, and Clement, of whom Irenaeus eloquently remarks had the "preaching of the Apostles still ringing [in his ears] and the tradition before [his] eyes" (cum adhoc insonantem praedicationem apostolorum et traditionem andte oculos haberet). This succession list has received a significant amount of attention. See Javierre, Antonio M, "In ecclesia": Ireneo, Adv haer 3, 3, 2," in Comunione interecclesiale collegialité - primato ecumenismo (Rome: LAS: 1972) 221-317; Abramowski, L. "Irenaeus, Adv Haer III 3,2: ecclesia Romana and omnis ecclesia; and ibid 3,3: Anacletus of Rome." JTS 28: (1977), 101-104; Nautin, P. "Irénée, Adv haer, III 3,2: Eglise de Rome ou église universelle?," RHR (1957) 151: 37-78.

${ }^{5}$ This account of salvation history is related his rule of faith found in various forms throughout $A H 3$ including: $A H$ 3.4.2, $A H$ 3.15.3 and $A H$ 3.16.6. The narratival character of the regula is debated. See Paul Blowers, "The Regula Fidei and the Narrative Character of Early Christian Faith," ProE 6.2 (1997): 199228. Nathan MacDonald, "Israel and the Old Testament Story in Irenaeus' Presentation of the Rule of Faith,” JTI 3.2 (2009): 281-98.

${ }^{6}$ AH 3.3.3.

${ }^{7}$ Wingren, Man and the Incarnation, 7.
} 
Matt 25:41. ${ }^{8}$ But this merely suggests the purpose of this arrangement is to argue for the continuity of salvation history under the provision of one God and Father who administers creation from its conception to the eschatological judgment of Satan. This unification of the plot of scripture is what Irenaeus terms its "hypothesis."10 The Gnostics, on the other hand, reflect a dualistic and polytheistic tendency and insert discontinuity between the God of the Old Testament and the preaching of the church represented in 1 Clement. ${ }^{11}$ In this case, Irenaeus' call upon Gen 1:1 and Gen 2:7 is a theological one that proves the continuity of the apostolic tradition represented in 1 Clement. $^{12}$

\subsection{AH 3.11.5,8: Son of God and God the Father}

The larger section AH 3.9.1-3.10.6 concerns Irenaeus' interpretation of the infancy narratives in the synoptic Gospels in contrast with the Gnostics. In AH 3.11.1-6, he transitions from discussing the synoptics to the Gospel of John. He even suggests the motivation for John's Gospel was the refutation of Cerinthus, a Gnostic working in Asia Minor. This is the earliest reference to the authorial intent of the Gospel and certainly a point Irenaeus received from Polycarp. These last three sections of $A H$ 3.11.7-9 defend the four-fold Gospel canon with the numerology reminiscent of the Gnostics. The intertestamental links between the incarnate Son of God and God the Father continue to pervade these sections, and within this continuity Gen 1-3 is decisive.

\footnotetext{
${ }^{8}$ cf. AH 2.30.9, AH 3.23.3.

${ }^{9} \mathrm{AH} 3.3 .3 ; \mathrm{cf}$. AH 3.5.3. The integrity of the arrangement of the Old Testament is also evidenced in Epid 8-30. Here Irenaeus identifies the direction of salvation history under the provision of the Father.

${ }^{10}$ This summary of salvation history is Irenaeus' "hypothesis" of 1 Clement, implying that Irenaeus is summarizing, not just salvation history, but the meaning of 1 Clement. This explains why there is no portion of 1 Clement that mirrors his synopsis. Rousseau located each of these episodes of salvation history in 1 Clement generally with the exception of the fires of hell in Matt 25:41. The absence of the Matt 25:41 from 1 Clement is an enigma. Rousseau points us to the work of B. Botte, who observes that the fires of hell are mentioned five times in 2 Clement. Irenaeus, if he was even aware of the existence of 2 Clement (the earliest references to 2 Clement are found in Origen), may have assumed it was a continuation of 1 Clement. "1 Clement," in The Apostolic Fathers I, trans. Kirsopp Lake, LCL 24 (Cambridge, MA: Harvard University Press, 1998), 125-27; Wilhem Pratscher, "The Second Epistle of Clement," in The Apostolic Fathers: An Introduction, 71-90 (Waco, Texas: Baylor University Press, 2010); Farkasfalvy, "Theology of Scripture," 320-24; Behr, Asceticism, 32-33. Robert Grant, Irenaeus, 47-48.

${ }^{11}$ Farkasfalvy, "Theology of Scripture," 321.

${ }^{12}$ Kannengiesser, "The 'Speaking God', 350.
} 


\subsubsection{AH 3.11.5: Creation and Blessing (Gen 1:1, Gen 1:9, Gen 1:11, Gen 2:6)}

In this section Irenaeus reads the miracle at the wedding feast at Cana in continuity with the creation accounts. He alludes to John 2:1 and 2:6 that frame Christ's first miracle with texts depicting God's creation of flora and water (Gen 1:1, Gen 1:11, Gen 1:9, and Gen 2:6) in order to reveal Christ's identity as the Creator in Gen 1-2. ${ }^{13}$ The God who made the earth in Gen 1:1, commanded it to bring fourth fruit in Gen 1:11, also created the waters in Gen 1:9 and the "springs" (fontes) that water the earth in Gen 2:6. Now just as the Son of God was with the Father in Genesis creating vegetation and water, the same person is found in the Gospels exercising authority over food and drink. While Johannine passages discuss miracles involving food and drink, Irenaeus also weaves them together with allusions to the feeding of the 5000 with the loaves and fishes in John 6:11 and the invitation to the marriage supper of the Lamb in Matt 22:3. ${ }^{14}$ Even though the Son of God had the capability to create ex nihilo as in Gen 1-2, he chose to take his own creation in his hands and blessed it. ${ }^{15}$ While the creation of flora and water in Gen 1 was a creation ex nihilo, the miracles in the Gospels are the restoration of his creative substances. A final allusion to John 1:18 binds these texts together arguing, that the Son who preexisted in the "bosom of the Father" (in sinu Patris) has now, through his miracles, manifest the invisible God by means of the visible incarnation. He applies the incomprehensiveness of the Father to the Son, who existed with the Father in the beginning. ${ }^{16}$ The instrumental medium for this revelation is the physical substances where the "incomprehensible" (incomprehensibilis) and "invisible" (invisibilis) God works by means of physical substances. For Irenaeus, this is what the Father has been doing through the Son from the beginning.

\subsubsection{AH 3.11.8: The Adamic Covenant (Gen 2:16-17)}

The same links between the economic activities of the Father though the Son continue in AH 3.11.7, where he argues the "first principles of the Gospel" (principia Eugangelii) are the existence of one God, the Maker of this universe and the Father of

\footnotetext{
${ }^{13}$ While Irenaeus is speaking about the miracle of the wedding feast at Cana in John 2, the language inuitati errant ad nuptias is closer to Matt 22:3. Mutschler, Das Corpus Johanneum, 222-39.

${ }^{14} \mathrm{cf}$. Rev 19:9

${ }^{15}$ Rousseau, SC 210. 282.

${ }^{16}$ cf. AH 3.16.6; AH 4.20.5; AH 5.16.2.
} 
Christ. He suggests the four canonical Gospels (Matthew, Mark, Luke, and John) are all unified in this fundamental perspective. These last three sections of AH 3.11.7-9 defend the four-fold Gospel canon using a kind of numerology that we have seen previously. Irenaeus concludes that there are four Gospels just as there are four quadrants to the earth, four directional winds, four pillars of the earth, four living creatures of Rev 4:7, ${ }^{17}$ a four-fold revelatory action of the Word, and four covenants. The "four covenants" (quattuor... testamenta) include: the Adamic Covenant, the Noahic Covenant, the Mosaic Covenant, and the New Covenant. The Adamic Covenant naturally echoes God's command in Gen 2:16-17. Adam is free to eat from any tree in the Garden except the tree of the knowledge of good and evil. Other than mentioning this as the only covenant prior to the Flood, he gives no further information. However, we cannot overlook that the Adamic covenant is continuous with the Noahic Covenant in Gen 9:8-16, the Mosaic Covenant in Exod 19-20, and the New Covenant summarized with the language of Eph 1:10. In her analysis of the covenants in Irenaeus, Susan Graham argues that they are real events and real relationships between God and humankind arranged for the growth and progress of the faithful. ${ }^{18}$ She refers to the relationship in the paradise as the "benchmark for all divine-human relationships." 19 The vision of the Lord walking and conversing with Adam prefigures the incarnation and New Covenant that "renovates humankind and sums up all things in himself by means of the Gospel" (renouat hominem et recapitulat in se omnia, Eph 1:10). ${ }^{20}$ The four-fold covenant structure, beginning with Adam (Gen 2:16-17) forms a progressive trajectory that prepares the faithful for the communion with God that Adam and Eve enjoyed in paradise.

\subsection{AH 3.18.1,7: Creation and Incarnation}

Donovan identifies a chiastic structure in AH 3.18.1-7 centering on a discussion of martyrdom in $A H 3.18 .5 .^{21}$ The bookends of this structure, $A H$ 3.18.1-2 and $A H$ 3.18.7,

\footnotetext{
${ }^{17}$ Regarding the four living creatures of Rev 4:7, he states the gospels "harmonize" (consonantia) with nature of the creatures around Christ's throne and then he identifies each symbol with its respective gospel: Human-Matthew, Eagle-Mark, Ox-Luke, and Lion-John.

${ }^{18}$ Susan L. Graham, "Irenaeus and the Covenants: 'Immortal Diamond," StuPat 40 (2006): 393-98, 394.

${ }^{19} \mathrm{Ibid} .$, 394. She also argues that the early part of Irenaeus' Epideixis follows a covenantal framework. Graham, "Structure and Purpose of Irenaeus' Epideixis," StuPat 36 (2001): 210-21.

${ }^{20}$ AH 3.11.8.

${ }^{21}$ Donovan's chiastic structure is identified as follows: A. Necessity of incarnation (AH III.18.1-2); B. Paul on the reality of Christ's redemptive suffering, death, and resurrection (AH III.18.2-3); C. Christ's
} 
contain common allusions to Gen 1-3 and, as a result, are related structurally and theologically. ${ }^{22}$ He combines Gen 1:26 with John 1:14 to discusses the necessity of the incarnation. The term "flesh" or "formation" (plasmati) and a related semantic field form strong connections between the creation accounts and the Johannine prologue. Gen 2:5 is read in continuity with Adam-Christ typology of Rom 5-6 in AH 3.18.7.

\subsubsection{AH 3.18.1: The Pre-existence of the Son (Gen 1:26, Gen 2:7)}

In $A H$ 3.18.1 he appeals to John 1:2-3 and John 1:10 to prove the preexistence of the Son in the beginning with the Father and his continued administration of creation through time. He unites the preexistence and incarnation of the Son that effects the recovery of the original creative form fashioned in the image and likeness of God. In Irenaeus' mind, there is an inherent link between the creation accounts and the Johannine prologue. Referring to the formation from the dust in Gen 2:7, he describes how the Word of God became "united to his own formation" (unitum suo plasmati) and, alluding to John 1:14, the Word was "made a passable human" (passibilem hominem factum)..$^{23}$ For Irenaeus the Word did not merely become flesh (John 1:14), but became what was his own formation (Gen 2:7). Preexistence and incarnation are united in Christ, who "recapitulated in himself a long narration of human beings" (longam hominum expositionem in seipso recapitulauit) and "in summary exhibited our salvation" (in compendio nobis salutem praestans, Eph 1:10). ${ }^{24}$ Grant suggests that this passage expresses the loss of both the image of God in Adam's disobedience, but Behr rightly notes that the eschatological thrust of Irenaeus' argument points towards the recovery of both the image and likeness in Christ and

teaching on his suffering and that of his disciples (AH III.18.4); D. If Christ did not suffer but flew away from Jesus, by what right did he exhort disciples to follow him? (AH III.18.5); E. Suffering of the Martyr's: differing views (AH III.18.5); $\mathrm{D}^{\prime}$. If Christ's suffering was not real, by what right did he exhort disciples to follow him? (AH III.18.6); $C^{\prime}$. Paul teaches that Christ was a man who by his obedience redeemed human disobedience (AH III.18.6); $\mathrm{B}^{\prime}$. Christ teaches that he claimed the strong man, freed the weak and gave salvation to the work of his hands destroying $\sin$ (AH III.18.6); $\mathrm{A}^{\prime}$. Necessity of incarnation (AH III.18.7). Donovan, One Right Reading, 83. Donovan does not explicitly combine $A H$ 3.18.1-2, as I have here, but it is evident that the themes and content is parallel and they should be understood as a unit in this chiastic structure.

${ }_{22}^{22}$ Donovan, One Right Reading, 83.

${ }^{23}$ Irenaeus also argues the Word was with the Father in the beginning and only recently united to his own formation (plasmo). This phrase, "united to his own creation," (unitum suo plasmati) is particularly important for Irenaeus and parallel phrases are found throughout AH 3. see: $\mathrm{AH}$ 3.10.4; $\mathrm{AH}$ 3.16.6; $A H$ 3.18.1, 6-7; $A H$ 3.19.3; and AH 3.21.9-10.

${ }^{24} \mathrm{AH}$ 3.18.1. 
the intertextual use of John 1:14 with Gen 1:26 supports his view. ${ }^{25}$ The validity of this intertextual connection is sealed with an allusion to Deut 32:4 that confirms the Adam-Christ analogy. He mentions that same passage again in AH 3.18.7.

\subsubsection{AH 3.18.7: Salvation and the Obedience of Christ (Gen 2:5)}

The discussion of the Incarnation resurfaces in $A H$ 3.18.7, where Irenaeus concludes the whole chiastic structure arguing that Christ, who was both God and man, could have vanquished the enemy and possessed salvation securely. ${ }^{26}$ The Bishop of Lyons remarks that unless humanity is joined to God, humankind could never partake of incorruptibility. ${ }^{27}$ While there are a number of texts cited in this section, he specifically harmonizes Gen 2:5 with Rom 5:12 and Rom 5:19. For Irenaeus, the destruction of sin and death could only be accomplished through God assuming the same substance formed from the dust in Gen 2:5. The phrase "originally molded from virgin soil" (primus de terra rudis plasmatus) conflates Gen 2:5 with Rom 5:19 in order to characterize the virginity of the one fashioned from the earth. The "virgin" soil exemplifies the nature of the untilled soil prior to God sending rain in Gen 2:6 or grasping the earth to form Adam in Gen 2:7. The creation of Adam from the "virgin soil" of Gen 2:5 mirrors the virgin birth of Christ. Not only does Irenaeus correspond the generations of Adam and Christ, he also contrasts Adam's act of disobedience with Christ's act of obedience. ${ }^{28}$ Through disobedience the first man ushered in sin and death for all, but through the obedience of Christ the faithful find salvation. To validate the legitimacy between the Adam-Christ analogy Irenaeus again turns to Deut 32:4, "God, true are his works" (Deus, uera opera eius). He links the term "work" (opera) with the concept of the untilled soil in Gen 2:5 and the incarnation and salvation of Christ in Rom 5:12, 19. The validity of the works of God is manifest in Christ's recapitulation of Adam's formation when he destroyed sin and death and restored humankind to life. ${ }^{29}$

\footnotetext{
${ }^{25}$ Grant, Irenaeus, 52; Behr, Anthropology, 90.

${ }^{26}$ It is still worth noting that this emphasis on obedience, observed by Wingren, acknowledges the union of the physical and ethical aspects of salvation. Wingren, Man and the Incarnation, 27-8.

${ }^{27}$ There is a close relationship between the use of Gen 2:5 and related intertexts in this section with Epid 30-34a and AH 3.21.10.

${ }^{28}$ Behr, Asceticism, 63.

${ }^{29}$ Here is rejects the ransom theory of atonement. Steenberg, of God and Man, 45; Wingren, Man and the Incarnation, 129.
} 
The placement of Gen 2:5 in this section demonstrates the way Irenaeus extends Paul's logic with his own harmonization. ${ }^{30}$ Francis Watson identifies this semantic structure in Rom 5 as demonstrative of the "asymmetrical analogy" between Adam and Christ in Paul's thought. ${ }^{31}$ He uses the same "as...so" ( $\dot{\sigma} \sigma \varepsilon \rho . .$. ov $\tau \omega \varsigma$ ) framework as Paul in Rom 5:12 and 5:19, but extends the asymmetrical relationship to include positive symmetry between the experiences of Adam and Christ. $^{32}$ Whereas Paul's comparison is purely contrastive, Irenaeus utilizes both contrastive and corresponding elements. ${ }^{33}$ Thus, Irenaeus extends Paul's typological relationship by harmonizing Gen 2:5 and Rom 5:12 in a way that develops into both comparative and contrastive elements.

\subsection{AH 3.19.3-20.1: God's Creative Work}

As we found $A H$ 3.18.1-7, Donovan also identifies another chiastic structure in $A H$ 3.19.1-21.9 directed at the Ebionites, a Jewish-Christian sect, who assume that Jesus was merely human and not divine. ${ }^{34}$ The central piece of the chiastic structure, $A H$ 3.20.3, contains the well-known Irenaean summary of the divine-human relationship: "The glory of the human being is God; in truth, the receptacle of the operation of God and of all God's wisdom and power is the human being" (Gloria enim hominis Deus, operationis uero Dei et omnis sapientiae eius et virtutis receptaculum homo). ${ }^{35}$ The entire chiastic structure is also oriented by the interpretation of Isa 7:14, and both $A H$ 3.19.3 and $A H$ 3.20.1 are positioned in the first half, or parts C-D of the chiasm. The corresponding section (AH 3.21.1-3) critiques the Ebonite preference for the translation "young woman" (עלדה, Isa 7:14) rather than $\pi \alpha \rho \theta \varepsilon ́ v o \zeta$,

\footnotetext{
${ }^{30}$ Orbe, La antropología, 280. In the context, Irenaeus explains the tension between sin and death and the law that develops from the intertextual linking of Rom 5:14, Rom 7:7, Rom 7:11-13.cf. Ibid., 297.

${ }^{31}$ Francis Watson, "Is there a Story in these Texts?," in Narrative dynamics in Paul: a critical assessment, ed. Bruce Longenecker (Louisville, KY: Westminster John Knox, 2002): 231-39, 237.

${ }^{32}$ In the next sentence, Irenaeus uses the preposition sic. Rousseau notes the preposition ouj $\tau \omega v$ as a direct allusion to Rom 5:19

${ }^{33}$ Orbe distinguishes between the functions of Rom 5:12 and 5:19 for Irenaeus' anthropology. The former distinguishes between the obedience and disobedience of Adam, while the latter, links the sin and death. Orbe, Antropologia, 284.

${ }^{34}$ Donovan's structure is as follows: A: To consider Jesus human only misinterprets Emmanuel (AH 3.19.1), B: Jesus God and human (AH 3.19.2), C: Because humans could not imagine it, the sign of Emmanuel was given (AH 3.19.3), D: Sign of Jonah: God's plan (AH 3.20.1), E: Glory of human: God. Receptacle of God's action: the human (AH 3.20.2), D': God became Savior, carrying out the plan ( $A H$ 3.20.3-4), $C^{\prime}$ : Sign of Emmanuel badly translated (AH 3.21.1-3), B': Emmanuel sign means Jesus God and human (AH 3.21.3-4), $\mathrm{A}^{\prime}$ : Extended interpretation of Emmanuel, with other texts supporting this interpretation (AH 3.21.5-9). Donovan, One Right Reading?, 84-5.

${ }^{35}$ AH 3.20.3.
} 
as cited in Matt 1:23. Undoubtedly, Irenaeus must be familiar with Justin's detailed argument on this point. ${ }^{36} \mathrm{He}$ frames human nature, created from the dust in Gen 2:7, as the substance (plasma) that Christ retrieves and restores back to life.

\subsubsection{AH 3.19.3: Creation and Resurrection (Gen 2:7)}

Irenaeus begins AH 3.19.3 with the logical argument that God gave humankind the sign of the virgin birth in Isa 7:14 because they would not expect it. He appeals to Ahaz's refusal to test the Lord and ask for the sign in Isa 7:12, because, in Irenaeus' reading, Ahaz would never expect a virgin could conceive. For this reason, the sign of virgin birth in Isa 7:14 is an unexpected sign. Not only this, but the imagery of "descending" (descendere) to the depths and the "ascending" (ascendere) to the highest in Isa 7:11 also conditions the nature of this sign and his interpretation uses Gen 2:7 as an intricate piece in his exegetical puzzle. ${ }^{37}$ First, he links Gen 2:7, Luke 15:4, and Eph 4:9 through the verbal associations of "handiwork" (plasma), "sheep" (ouem), and "earth" (terra) and each of these represent the object of salvation. The things of the "earth" (terra) in Eph 4:9 are compared with the "sheep" (ouem) of Luke 15:4 and which was indeed his own peculiar "handiwork" (plasma) of Gen 2:7. Second, the "descending" (descendere) imagery refers to the Incarnation and conceptually links Isa 7:11a, Gen 2:7, Luke 15:4, and Eph 4:9. The "ascending" (ascendere) imagery unites Isa 7:11b, Gen 2:7, Luke 15:5-6, and Eph 4:10 and completes the Christological act of salvation. Together these texts form a sophisticated Christological summary of Incarnation and ascension with the object of Christ's descent and ascent as the recovery and restoration of human nature formed in Gen 2:7. The reference to the "human" (hominem) (or human nature) found in the allusion to Luke 15:4-5 refers back to the substance (plasma) formed in Gen 2:7. This Christological movement also points back to the meaning of Emmanuel (Isa 7:14), who descended and ascended to restore human nature. The subsequent allusion to 1 Cor 15:20 completes the thought of this intertextual linking with Gen 2:7. The result of Christ's descending and ascending is that he becomes the first fruits of the resurrection. Human nature was found through the resurrection of Christ "creating in his own person" (in semetipso faciens) a restored humanity. After

\footnotetext{
${ }^{36}$ cf. Dial 43.8; Dial 67.1; Dial 70.3; Dial 84.3.

${ }^{37}$ AH 3.19.3.
} 
Christ restores human nature in himself he ascends and entrusts his humanity to the Father. The nature of Adam's forming is now seen in light of his forming, or more appropriately re-forming, in Christ.

The remaining portion of $A H$ 3.19.3 imagines the resurrection through a network of other texts including: Eph 1:22/Col 1:18, Phil 3:9, 1 Cor 15:23, Col 2:19, Eph 4:16, John 14:2, Rom 12:4/1 Cor 12:12, 20. ${ }^{38}$ Together they serve to reinforce the same point as 1 Cor 15:20, so there is a sense in which we could include these texts in the same kind of intertextual relationship. Each of these texts touches upon some aspect of the restoration and resurrection of the human nature created in Gen 2:7. For example, he alludes to the resurrection imagery of Eph 4:16 and identifies Christ as the "head" (caput) who was first resurrected following by the remaining parts of the body. In the resurrection, the various bodily parts consisting of "joints" (compagines) and "bonds" (coiunctiones) shall blend together and reunite so that the body is properly fitted together and sustained by the "increase of God" (augmento Dei, cf. Gen 1:28). ${ }^{39}$ This is the same substance of the flesh created from the dust in Adam, tainted through disobedience and inherited by all succeeding generations. This casts the eschatological resurrection of the flesh as a reenactment of the formation from the dust in Gen 2:7.

\subsubsection{AH 3.20.1: Human Disobedience and God's Creative Work (Gen 3:1-8)}

Irenaeus conveys that the repercussions of Adam's sin did not frustrate God nor impede divine providence. God remained patient because Adam dwelt within a divinely constructed economy oriented toward the advent of the Son. From a divine perspective, humankind remained the object and instrument of God's divine work. The special relationship is typified, for Irenaeus, in parallels with the Jonah narrative. He reads the disobedience of Adam and Eve and their response in Gen 3:18 with explicit allusion to Jonah 1:9, 17, Jonah 2:1-2, Jonah 3:1 and Jonah 3:8-9. Like Jonah, all the faithful shall receive an unexpected salvation and resurrection from the dead depicted in the "sign of Jonah" (Matt 12:39-40).

He begins by comparing the disobedience in Eden with the disobedience of Jonah. Arguing strongly for continuity between the events in the paradisiacal life of

\footnotetext{
${ }^{38}$ AH 3.19.3.

${ }^{39}$ AH 3.19.3.
} 
Adam and Eve, Behr believes there was no period of time when Adam was "not engulfed" by the so-called whale, or Satan, though this overstates the case seeing that Irenaeus distinguishes between the conditions of life before and after Adam's disobedience. ${ }^{40}$ There is, according to Behr, "no lost golden age of primordial perfection." ${ }^{41}$ He admits, however, that Irenaeus will speak about Adam's prelapsarian condition in instances, such as $A H$ 3.22.3, where he utilizes the AdamChrist typology. ${ }^{42}$ Behr is correct that the conditional nature of the divine economy, even in a paradisiacal state, allowed for the activity of Satan from the beginning, and the use of the Jonah narrative in relation Gen 3:1-6 suggests a greater degree of continuity between the pre-lapsarian and post-lapsarian conditions of Adam and Eve. ${ }^{43}$ This, as we will see, is also suggested by the use of Genesis imagery in the descriptions of the eschatological state. The divine economy is ordered pedagogically to acquaint humankind with their weakness and bring about their salvation. ${ }^{44}$ Just as God allowed Jonah to be swallowed up by the whale (Jonah 1:17) so that he might bring about the unexpected conversion of the Ninevites (Jonah 3:89), so also in the beginning God permitted humankind to be swallowed up by the "great whale" (magno ceto) who became the author of sin (John 8:44). The "great whale" (magno ceto) is, of course, Satan, who deceived the first couple in paradise by means of the serpent in Gen 3:1-5. ${ }^{45}$ Naturally while the snake and whale are distinctive species, no doubt Irenaeus is thinking of the conceptual connections between Satan's use of an animal in the narrative of Adam and that of Jonah. In the end God knew humanity's entanglement, just like Jonah's, would not last because God arranged a plan of salvation through the "sign of Jonah" (Matt 12:39-40). Despite Satan's continual activity of defection, revolt, and apostasy, by means of the Word, God ushered in salvation and the resurrection from the $\operatorname{dead}^{46}$ Irenaeus continues describing this resurrection, which connects the experience of Jonah with the faithful. In the same way that Jonah typifies Adam and

\footnotetext{
${ }^{40}$ Behr, Asceticism, 49.

${ }^{41}$ Ibid., 49.

${ }^{42}$ Ibid., 49 n. 51.

${ }^{43}$ The language "pre-lapsarian" and "post-lapsarian" may be anachronistic, but we continue to retain the language for clarity. Steenberg, Irenaeus, 153.

${ }^{44}$ Behr, Asceticism, 49-50.

${ }^{45}$ AH 3.20.1. Rousseau translates the Latin fuit patiens as "a permis," but Behr prefers "bear" after comparing similar passages and based upon the assumption that God was actively involved in the events. Behr, Asceticism, 45 n. 39, 48 n. 49.

${ }^{46}$ Wingren, Man and the Incarnation, 48.
} 
Eve's fall, so also does he typify the resurrection of the faithful. Like Jonah, the faithful will receive an "unexpected" (insperabilem) salvation and rising from the dead and praise God in the same manner of Jonah saying, "I cried by reason of mine affliction to the Lord my God, and He heard me out of the belly of hell" (Clamaui ad Dominum Deum meum in tribulatione mea et exaudiuit me de ventre inferni). ${ }^{47}$ The nature of salvation as unexpected and the emphasis on glorifying God for resurrection are expressed with an allusion to 1 Cor 1:29 that, "all flesh should not glory in the Lord's presence" (non glorietur in conspectus Domini omnis caro). ${ }^{48}$ Irenaeus wishes to ensure that no one assumes salvation is inherited naturally or derived from human work. Therefore, in conjunction with Jonah 1:9, 2:2, and 1 Cor 1:29, he returns again to an allusion to Gen 3:5. Alluding to the words of Satan's deception, Irenaeus argues that the serpent deceived Adam and Eve by persuading them that they would "become like God" (similes esset Deo). ${ }^{49}$ Adam and Eve became ungrateful towards God and considered themselves equal to God. But in light of these attitudes, humankind should praise God all the more when they receive an unexpected salvation and indeed "become like God" in the resurrection.

\subsection{AH 3.21.10: Adam, Christ, and Recapitulation (Gen 1:26, Gen 2:5,}

\section{Gen 2:7)}

Irenaeus has already discussed recapitulation in $A H$ 3.16.6 and $A H$ 3.18.7, but the present context (AH 3.21.10-3.23.8) offers the most developed explanation of this theology of recapitulation. As we noted previously, this section follows a chiastic argument on the nature and character of the Incarnation. The Incarnation unifies the trajectory of the economy manifested in the typology of Adam and Christ. ${ }^{50}$ The basis for recapitulation is the "similitude" (similitudinem) between Christ and Adam, not only in terms of their formal substances, but also in their actions.

Highlighting the similitude between Adam and Christ, he begins with the summary statement that Christ has "recapitulated himself in the ancient formation

\footnotetext{
${ }^{47}$ AH 3.20.1. He cites both Jonah 1:9 and Jonah 2:2, though he exchanges the "belly of the fish" (દ́k $\tau \eta \varsigma$

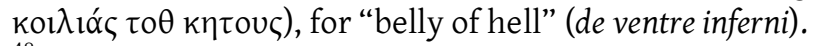

${ }^{48}$ AH 3.20.1.

${ }^{49}$ AH 3.20.1; cf. Epid 32-33.

${ }^{50}$ Behr, Asceticism, 62-3. Steenberg, Irenaeus, 109.
} 
of humankind" (antiquam plasmationem in se recapitulatus est, Eph 1:10). ${ }^{51}$ This Pauline imagery introduces a network of texts including: Gen 2:5, Gen 2:7, John 1:3, Rom $5: 12,19 .^{52}$ As we have seen elsewhere, he interprets the condition of the soil prior to the creation of Adam in Gen 2:5 as "untilled and yet virgin" (rudi terra et de adhuc uirgine) because there was no rain to agitate the soil and no one to till the ground..$^{53}$ Steenberg presses the ontology of Irenaeus' image, suggesting his reading of Gen 2:5 communicates both "divine and material in the constitution of the human person." ${ }^{54}$ But, as Osborn argues, under the provision of a divine economy oriented toward the Incarnation, the focus extends beyond the original human constitution. Adam is fashioned from the untilled soil precisely because Christ would be born from a virgin.

Irenaeus also reminds his readers that the Word of God, through whom all things were made (John 1:3), forms the plasma of Adam from the earth; the same substance assumed in the Incarnation of the Word. This textual arrangement puts Irenaeus' logic of recapitulation on display and parallels the generation of Adam and Christ by means of explicit intertextual connections. In fact the effectiveness of recapitulation hangs on the "likeness" (similitudinem) of Christ and Adam. As we have argued, Irenaeus actually extends Paul's typology with explicit references to particular texts in Gen 1-2, as well as other New Testament references. Nielson's study of Adam-Christ typology in Irenaeus neglects this points when he contrasts the meaning of Rom 5:12 and 19 (along with 1 Cor 15) saying: "Paul is concerned with the second Adam, Irenaeus with the second Adam." ${ }^{55}$ Paul, Nielson assumes, is concerned exclusively with the salvific arrangement of Adam and Christ, while Irenaeus' is concerned with their corresponding physical constitution. Nielson's evaluation erects a false contrast that disregards the intertextual networks Irenaeus creates with the Pauline imagery. Contrary to Nielson's assumptions, Irenaeus is not concerned with Paul's original intent in Rom 5:12, 19 apart from the rest of scripture, but he is using the Pauline analogy to establish broader connections

\footnotetext{
${ }^{51}$ AH 3.21.9.

${ }^{52}$ The final clause of $A H$ 3.21.9 is actually the intro to $A H$ 3.21.10, see SC 211:426.215.

${ }^{53}$ AH 3.21.10. The same emphasis on "virgin soil" is made in AH 3.18.7; Dem 32; AH 3.21.10; and AH 3.23.2.

${ }^{54}$ Steenberg, Irenaeus, 110.

${ }^{55}$ Nielson, Adam and Christ, 82. Emphasis is original.
} 
between Adam and Christ throughout scripture. ${ }^{56}$ This is not to say that Irenaeus and Paul utilize the Adam-Christ typology in the same way, but their distinction is one of degree not kind. Irenaeus' concern for the substance of Adam's flesh was an extension of the Pauline analogy that connects Rom 5:12, 19 with Gen 2:5, Gen 2:7, and John 1:3.

Following the argument from Genesis, Paul, and John, Irenaeus continues communicating the theological and exegetical logic of recapitulation. He provides several rational arguments for the continuity and consistency between Adam and Christ. First, he uses the dialectical imagery 1 Cor 15:45-47 and the imagery of Adam's formation in Gen 2:7 in a simple counterfactual conditional statement. He reasons if first Adam (1 Cor 15:45) had a man for his father and was born of a "male seed" (semine viri), then it would be right to argue that the second Adam (1 Cor 15:47) was born of Joseph. ${ }^{57}$ This clause mixes the condition of simple past tense with the perfect "had" (habuit) in the protasis and a present subjunctive "might say" (discerent) in the apodosis. With this change in modality, Irenaeus is conceding that if Adam had a natural birth then one certainly could say that Christ received his birth from Joseph. ${ }^{58}$ However, given this is a counterfactual condition, the thrust of the argument is that Adam did not have a natural birth from a "male seed" (semine viri) and, therefore Christ could not have a natural birth from Joseph.

To extend his first statement, Irenaeus provides a second conditional clause. He states that if the first Adam was formed from the dust (Gen 2:7) by the Word of God, then it is proper that the Word himself when recapitulating Adam within himself ought to have an analogous birth. In this case the protasis and apodosis are presented in the perfect (plamsatus est) and imperfect (oportebat) tenses respectively, which makes this statement in Irenaeus' view a simple fact. In other words, Adam was certainly created from the dust; therefore, Christ was certainly formed in the likeness of Adam. This emphasis communicates how important the creation from the dust in Gen 2:7 is for Irenaeus' Christology as the very nature of Christ's humanity hinges upon the correspondence between the virgin birth and Adam's formation from the dust.

\footnotetext{
${ }^{56}$ Ibid., 68. For example, in next section (AH 3.22.3) he will comment on the Adam-Christ connections in Luke's genealogy.

${ }^{57}$ AH 3.21.10. The emphasis on "male seed" (semine viri) is aimed at the Ebionites, who he has already addressed in $A H$ 3.19.1ff.

${ }^{58}$ See $A H$ 3.21.9; $A H$ 3.22.1.
} 
Given the crucial similitude between that of the Adam-Christ, Irenaeus anticipates a question that logically follows: "Why, then, did God not again take up the dust, but designed that the formation [Christ] should be made of Mary? (Quare igitur non iterum sumpsit limum Deus, sed Maria operatus est plasmationem fieri?)." ${ }^{59}$ If the similitude between Adam and Christ is so essential, as Irenaeus understands Paul to be arguing in Rom 5:12, 19 and 1 Cor 15:45, 47, why are their specific modes of creation not identical? Irenaeus answers this objection with the logical remark that a second formation from the dust would produce a second race that is an altogether separate formation (alia plasmatio), which would also require a separate means of salvation. ${ }^{60}$ By different formation, he implies a distinct human race fashioned from the same fleshy substance, but not in the physical line of Adam. As Paul expresses Adam unifies all humanity in himself and through his disobedience death spreads to all humanity. Likewise, Christ comprises all humanity in his obedience, thus reversing the effects of Adam and reviving human nature. Irenaeus' theological and exegetical reflection is guided by the conviction that Christ must be analogous to Adam in order to convey salvation to the same flesh of Adam that was formed from the dust.

\subsection{AH 3.22.1-4: The Typology of Adam, Christ, Eve, and Mary}

The section of $A H$ 3.22.1-4 continues the discussion of recapitulation from $A H$ 3.21.10, but in this case Irenaeus' polemic is set against the Valentinians, rather than the Ebionites who deny the virgin birth. For the Bishop of Lyon, those who reject Christ's human nature reject the "similitude" (similitudinem) between Adam and Christ. As we argued, Irenaeus' concern is the analogy between Adam and Christ, which he extends through a range of textual connections. His argumentation incites a continued scriptural correlation between the first and second Adam, beginning with the closing line of $A H$ 3.21.10 and extending through $A H$ 3.22.1-4. Within this section Irenaeus links Gen 2:7 with Matt 5:5, Gal 4:4, and Rom 1:3-4 in order to demonstrate that the meekness of the flesh derived from the earth is the same flesh Christ assumed. He also points to the weakness of Christ's body in the Gospel accounts where he required food, grew tired, grieved, sweat blood, and was pierced

\footnotetext{
${ }^{59} \mathrm{AH} 3.21 .10$.

${ }^{60}$ AH 3.21.10.
} 
revealing blood and water. In the final two sections he extends the Adam-Christ typology with the discussion of the Eve-Mary typology.

\subsubsection{AH 3.22.1: The Blessed Meekness of the Flesh (Gen 1:26, Gen 2:7)}

He begins his polemic with another conditional clause that entertains the converse idea of the second conditional clause mentioned in $A H$ 3.21.10 dependent upon his concepts of image and likeness found in Gen 1:26 and linked with John 1:3, Matt 5:5, Rom 1:3-4, and Gal 4:4. He argues that if Adam was formed from the hand of God (Gen 2:7), but not Christ, then he would not preserve a likeness to Adam who was made in the image and likeness of Christ (Gen 1:26). God would be an "inconsistent Artist" (inconstans Artifex) and unable to manage his own creation. ${ }^{61}$ The term "Artist" (Artifex), as Osborn notes, emphasizes the notions of coherence and proportion. ${ }^{62}$ Since Adam was made in the image and likeness of Christ then the divine Artist would preserve the likeness of Adam in Christ. ${ }^{63}$

The demand for similitude between the formations of Adam and Christ prompts Irenaeus to correlate the substance of Adam's flesh formed in Gen 2:7 with Christ's humanity. Echoing Gen 2:7, he makes the general anthropological statement that humankind is formed from a body taken from the earth and a soul imparted by the Spirit of God. When the Word of God recapitulated himself in the form of his own handiwork, he received a body from Mary that connected him to the substance of Adam's body fashioned from the "earth" (terra). The earthly substance that was used to fashion Adam is characteristically ignoble or "meek" (mites), but when the Word assumes flesh he "blesses the meek, because they shall inherit the earth" (beatificat mites, quoniam ipsi hereitabunt terram).$^{64}$ For Irenaeus, the meek who inherit the "earth" (terra) in Matt 5:5 are those who receive the same flesh fashioned from the "earth" (terra) in Gen 2:7. In other words, assuming flesh in his Incarnation, the Son of Man "blesses" (beatificat) the weak flesh that is inherited by all those born in line of Adam. ${ }^{65} \mathrm{He}$ also unites these texts with Gal 4:4 and Rom 1:3-4, but he offers virtually no commentary on these passages. Instead, bound by their verbal and

\footnotetext{
${ }^{61}$ AH 3.22.1.

${ }^{62}$ Osborn, Irenaeus, 18-20.

${ }^{63}$ AH 3.22.1.

${ }^{64}$ The use of the title Son of man suggests Irenaeus is drawing upon the Lukan account of the beatitudes.

${ }^{65}$ Wingren misunderstands Irenaeus' interpretation of this text. Wingren, Man and the Incarnation, 186.
} 
conceptual connections, Gal 4:4 and Rom 1:3-4 are themselves commentary on the nature of the Incarnation and the relationship between Gen 2:7 and Matt 5:5. In Gal 4:4 Irenaeus notes that Paul expresses the humanity of Christ "plainly" (manifeste) saying "God sent His Son made of a woman" (misit Deus Filium suum, factum de muliere) and he adds that the same point is made in Rom 1:3-4, "but His Son, who was made of the seed of David according to the flesh" (De ilio autem, inquit, euis, qui factus est ex semine David secundum carnem). ${ }^{66}$ The phrases of "made of a woman" (factum de muliere) and "made of the seed of David" (qui factus est ex semine David) reflect the same theological concept as the title "Son of Man" and those who inherit the earth in Matt 5:5. Taken together, this network of texts forms a paradigmatic link between the body that is fashioned from the dust in Gen 2:7 and flesh of the incarnate Christ.

\subsubsection{AH 3.22.2-3: Christ's Body and Adam's body (Gen 2:7)}

In $A H$ 3.22.2, Irenaeus continues the same discussion, explaining the nature of Christ's incarnate flesh. As characteristic of a body from the earth (Gen 2:7), Christ required food, grew tired, was wounded, grieved, sweat blood, and was pierced, revealing blood and water (Matt 4:2, John 4:6, Psalm 68:27 LXX, John 11:35, Luke 22:44, Matt 26:38, and John 19:34). The networking of these texts is dependent upon their connections to Christ's experience in the body. Together the echoes and allusions form an extended anthropological commentary upon the nature and weakness of the flesh formed from the dust in Gen 2:7. After citing these passages in succession, Irenaeus remarks they all express "signs of the flesh" (signa carnis) formed from the earth. ${ }^{67}$

Discussion of the Adam-Christ typology continues in AH 3.22.3 and reinforces the observations of AH 3.22.1-2. The central allusion is Luke's genealogical account that, as Irenaeus notes, is written backwards beginning with Christ in Luke 3:23 and concluding with Adam in Luke 3:38. He interprets the passage theologically, as indicating Christ had recapitulated in himself all generations between them. Thus, the very structure of the genealogical list reflects the recapitulating acts of Christ and his reversal of Adam's sin. From this arrangement Irenaeus draws the

\footnotetext{
${ }^{66}$ AH 3.22.1.

${ }^{67}$ AH 3.22.2.
} 
conclusion that the Word of God existed logically prior to Adam and ultimately "prefigures" (praeformauerat) his Incarnation in Adam. ${ }^{68}$ In the same context

Irenaeus cites Rom 5:14, where Adam is said to be a "type of Him that was to come" (typus futuri) ${ }^{69}$ Adam's physical form was a type of Christ in whose image Adam was originally formed..$^{70}$ This is also supported by an allusion to 1 Cor 15:46: "God predestined the first man should be of an animal nature, in order that he might be saved by the spiritual" (praedestinante Deo primum animalem hominem uidelicet uti ab spiritali saluaretur). ${ }^{71}$ This makes clear Irenaeus' understanding of typus is highly literal and physical. ${ }^{72}$ In the flow of Irenaeus' argumentation, these textual allusions in $A H$ 3.22.3 are related to the discussion and content of $A H 3.22 .1-2$, all of which depend upon allusions to the formation of Adam in Gen 2:7. The texts of Luke 3:2338, Rom 5:14, and 1 Cor 15:46 are the theological links connecting the "end" (finem) in Christ with the "beginning" (initio) in Adam so that Irenaeus envisions the whole of Gen 1-3, and indeed the whole Old Testament, as linked with the New Testament in a "single pattern of salvation history."73

\subsubsection{AH 3.22.4: From Adam and Christ to Eve and Mary (Gen 1:28, Gen 2:25, Gen 3:6)}

Following this delineation of Adam-Christ typology in AH 3.22.4, Irenaeus

transitions into a description of the Eve-Mary typology. Given Irenaeus is one of the first theologians to comment on the Eve-Mary connections, his comments have generated significant discussion. ${ }^{74}$ While Irenaeus comments on the Eve-Mary

\footnotetext{
${ }^{68}$ AH 3.22.3.

${ }^{69}$ AH 3.22.3.

${ }^{70} \mathrm{AH}$ 3.22.3. This argument is interesting because it implies Christ's predisposition to save necessitated something to save, which resulted in the creation of Adam. Steenberg believes this is some form of necessitarianism and one of Irenaeus' more controversial statements. Steenberg, Irenaeus, 34. On the nature of this phrase see also Behr, Anthropology, 58; Orbe, Anthropologia, 491ff; Wingren, Man and the Incarnation, 5-7.

${ }^{71}$ AH 3.22.3.

72 Behr, Asceticism, 58 n. 81.

${ }^{73}$ Donovan, One Right Reading?, 88.

${ }^{74}$ Dunning, "Virgin Earth, Virgin Birth." Tina Beattie, "Mary in Patristic Thought," in Mary: The Complete Resource, ed. Sarah Jane Boss, 75-105 (New York: Oxford University Press, 2007), 86-7. Steenberg, "The Role of Mary as Co-recapitulator in St. Irenaeus of Lyon," VC 58 (2004): 117-37. Luigi Gambero, Mary and the Fathers of the Church: The Blessed Virgin Mary in Patristic Thought, trans. Thomas Buffer (San Francisco: Ignatius, 1999), 56; Jaroslav Pelikan, Mary Through the Centuries: Her place in the History of Culture (New Haven, CT: Yale University Press, 1996), 42-52; D. Ramos-Lissón, 'Le Role de la femme dans la théologie de saint Irénée," StuPat 21 (1989): 163-74; Orbe, “La Virgen María abogada de la virgen Eva; en torna a s. Ireneo adv. haer. V. 19, 1)," Greg 63 (1982): 453-506; Jose Antonio de Aldama, María en la patrística de los siglos I y II (Madrid: Editorial Catholica, 1970); Jean Plagineux, "La
} 
typology and their respective roles elsewhere, the present section is the most developed explanation. ${ }^{75}$ Although many studies focus on gender issues, Steenberg provides a theologically developed understanding of this typology and argues for a subordinate, yet necessary role of Mary as "co-recapitulator" with Christ. ${ }^{76} \mathrm{He}$ appreciates the inherent "social" role of Eve in relation to Adam, thereby extending Osborn's previous observation of mere aesthetic parallelism between the experiences of Adam and Christ. ${ }^{77}$ Within the broader contours of Irenaeus' argument in AH 3.22.1-4, he places the Eve-Mary typology in continuity with the Adam-Christ typology as another means to unifying both Testaments in a single trajectory of salvation history.

However, the theological coherence of the Eve-Mary typology continues to guide Irenaeus' intertextual networking in continuity with the textual matrix of the Adam-Christ typology in the preceding sections. Like the Adam-Christ typology, the Eve-Mary typology depends upon several corresponding (or contrasting) characteristics recorded in their respective narratives and expressed through reflection on a network of texts including: Gen 1:28, Gen 2:25, Gen 3:6 with Deut 22:23-24, Psalm 44:17, Matt 19:30, Matt 20:16, Luke 1:38, Luke 3:23-38, Col 1:18, and Heb 5:9. First, following the same contrastive nature of Adam and Christ, Irenaeus distinguishes the disobedience of Eve from the obedience of Mary. While Eve was disobedient when she ate from the tree of knowledge in Gen 3:6, Mary is obedient when she proclaims to the angel, "Behold your handmaid, Lord, be it unto me according to your word" (Ecce ancilla tua, Domine, fiat mihi secundum verbum tuum, Luke 1:38). ${ }^{78}$ The disobedience of the former, Irenaeus surmises, became the "cause of death" (causa... mortis), while obedience of the latter became the "cause of life" (causa... salutis). ${ }^{79}$ Therefore, Eve and Mary are instrumental in the root causes of death and life respectively, which are effected through the corresponding actions of

doctrine mariale de saint Irénée," RSR 44 (1970): 179-89; Orbe, "El pecado de Eva, signo de divieion', OCP 29 (1963): 305-30. Steenberg hopefully frames Irenaeus' uses of Eve-Mary typology into three classifications: 1) anti-adoptionist, 2) anti-doectic, and 3) recapitulative. Steenberg, "The Role of Mary," 119.

${ }^{75}$ cf. Epid 33. AH 3.16.7; AH 4.27.1; AH 4.33.11; AH 5.19.1.

${ }^{76}$ Steenberg, "The Role of Mary," 118; Dunning, "Virgin Earth," 59-60.

${ }^{77}$ Osborn, Irenaeus, 51,75-6, 101. There appears to be another chiasm in AH 3.21.10-22.4 centered on recapitulation in Luke's genealogy, which demonstrated the need for further study on the structural nature of $A H 3$.

${ }^{78} \mathrm{AH} 3.22 .4$.

${ }^{79} \mathrm{AH}$ 3.22.4. The reference of "Mary the Virgin" most naturally alludes to Luke 1:34 in the immediate context. 
Adam and Christ. The parallelism between Adam and Christ, therefore, is strengthened by the concurrent disobedience of Eve and obedience of Mary, who is shown to be a "necessary and essential" means for the recapitulatory work of Christ. $^{80}$

Second, similar conceptions of virginity are found in both Eve and Mary. While Mary's virginity is plainly recorded in the Gospels (i.e. Matt 1:23-25, Luke 1:2734), Irenaeus cites Gen 2:25, "they were both naked in Paradise and were not ashamed" (utrique nudi in Paradiso et non confundebantur), to prove Eve's virginity. Irenaeus interprets this text to mean that Adam and Eve were prepubescent children in paradise who kissed and embraced each other in all holiness and felt no shame in their nakedness because they had no knowledge of procreation. ${ }^{81}$ This state of childhood innocence, however, is merely the initial stage in the course of human growth and maturity that includes procreation. This notion of anthropological progression is located in his conflation of Gen 2:25 with Gen 1:28, where he interprets the divine commands "increase and multiply" as sequential stages of human growth and development. ${ }^{82}$ The term "increase" (adolescere) implies human maturity towards the transition into adulthood, while the term "multiply" (multiplicari) suggests human reproduction. For Irenaeus procreation has always been part of God's economy as a means to guide God's creatures toward the divine life.

Third, the virginal correspondence is complemented by their respective betrothals. Irenaeus points to legal nature of betrothal in Deut 22:23-24 to argue that a betrothed virgin is actually considered a wife under Mosaic Law. Therefore Mary, who was "betrothed" (desponsatus) to Joseph, could be considered his wife. Rousseau argues that the application of Deut 22:23-24 applies exclusively to the

\footnotetext{
${ }^{80}$ Steenberg, "The Role of Mary," 118.

${ }^{81}$ Epid 14; Dunning, "Virgin Earth, Virgin Birth," 64; Both Behr and Donovan criticize Orbe for pressing the Eve-Mary typology in relation to the role of the Spirit and marital intercourse beyond the evidence in Irenaeus' writings. See Donovan, One Right Reading?, 91-2 n. 19. Behr, Asceticism, $111 \mathrm{n}$. 70. The same criticism is warranted for Dunning's attempt to differentiate Irenaeus' notions of "virginity" as a means to critique the inconsistencies in Irenaeus' logic of recapitulation. Like Orbe, Dunning forces Irenaeus to answer questions of gender and sexuality that are not altogether explicit in his writings. As Donovan remarks quite clearly (following the work of Rebecca Lyman): "Absent here [AH 3.22.4] is any suggestion of the impact of sexuality on either Eve's sin or Mary's obedience." Donovan, One Right Reading?, 88. Donovan refers us to an unpublished presentation of Lyman entitled "Irenaeus on Eve: The Christological Connection," where Lyman argues that what is clear in Irenaeus is simply that both sexes, male and female, are unified in the resurrected humanity of Christ and fully restored in the eschaton. cf. Behr, Asceticism, 210.

${ }^{82}$ AH 3.22.4; Behr, Asceticism, 112; Dunning, "Virgin Earth," 66.
} 
situation of Mary because Irenaeus would recognize that Eve is espoused to Adam and not engaged..$^{83}$ For Irenaeus, this logical set of conceptual and textual interconnections, including obedience/disobedience, virginity, and betrothal, signifies a circling back (recirculationem significans) from Mary to Eve reinforcing the aesthetic stability of the Adam-Christ typology. ${ }^{84}$

Summarizing their recapitulative roles, or the "circling back" (recirculationem) from Mary to Eve, de Aldama argues the disobedience of Adam and Eve is undone through the obedience of Mary and Christ. Emphasizing Mary's obedience, de Aldama shows how she unties the knot that was secured through Eve. ${ }^{85}$ This summary, however, leaves open the question of the nature of the "bonds" (compagines) that Eve inflicted, which Mary conversely untied. In this context, Irenaeus uses several parallel images to speak of the relationship fashioned between Eve and Adam including: "the binding of the bonds" (compagines adligationis), "first union" (primae conjunctiones)- or "first bond" (primam... compaginem)- and "knot" (nodus). ${ }^{86}$ Interpreting this "bond" between Adam and Eve, Steenberg remarks that this "knot" (nodus) refers specifically to the fact that "Eve's disobedience had bound the nature of human relationships into a detrimental state bent on turning men away from the intentions of God." ${ }^{87}$ This "knot," therefore is purely a metaphorical (or soteriological) "knot" illustrating the sinful condition of human nature bound to sin through disobedience. It is strange, however, given the context and the discussion on marriage, that no one has observed the echoes of the union of Adam and Eve becoming one flesh in Gen 2:24 (Matt 19:6) ${ }^{88}$ While the

\footnotetext{
${ }^{83}$ SC 210.375-6.

${ }^{84}$ Given the ascetic harmony between Adam, Eve, Mary, and Christ, I think the terminology "AdamChrist typology" and "Eve-Mary typology" runs the risk of being unhelpful, because it inherently divorces the theological interconnectiveness of these typological images. The notion of "ascetic harmony" on the other hand is not textually (or scripturally) based and does not explain how Irenaeus corresponds the specific characteristics of Gen 1-3 with the Gospels. Given these are the prevailing scholarly terms, I continue to use them even if they are restrictive.

${ }^{85}$ de Aldama, María, 278-93.

${ }^{86}$ AH 3.24.4. He also uses the verbs colligatum est and adligauit to illustrate the act of binding.

${ }^{87}$ Steenberg, "The Role of Mary," 136.

${ }^{88}$ This echo is not observed in BP or SC. Orbe recognizes all other references in this context, but does not mention Gen 2:24 or Matt 19:6. Orbe, Anthropologia, 248-9; cf. Steenberg, "The Role of Mary," 12930. Rousseau argues the legal imagery of Deut 22:23-24 that Irenaeus uses to prove that Mary was Joseph's wife even if she was merely betrothed to him could not refer to Adam and Eve, precisely because it would be obvious to Irenaeus that Adam and Eve were espoused. In making this argument he indirectly proves that Irenaeus is thinking in terms of Adam and Eve's union. SC 210.375-6. Furthermore, the contextual and linguistic support is overwhelming. Irenaeus cites Gen 2:25 in this section as well as Matt 19:30/20:6 and alludes to marriage imagery which constitutes the themes of Gen 2:24 and Matt 19:6. The imagery while not identical is close enough to constitute and clear echo
} 
language is only loosely connected, Irenaeus has just concluded that Eve and Mary are betrothed to Adam and Joseph (although Joseph is not mentioned by name). He implicitly alludes to the actual union of marriage (Gen 2:24, Matt 19:6), which he applies in metaphorical (although realistic) manner to illustrate the effects of Eve's disobedience. In other words, the "knot" between Eve and Adam is their nuptial union that Irenaeus applies metaphorically to the binding of humanity to sin and death. This does not imply that Irenaeus disparages marriage, but he recognizes the physical and mystical nuptial union between the first couple (Gen 2:24), though coordinating acts of disobedience, bound humankind to sin and death.

While Irenaeus' exegetical acumen is praiseworthy and there is great strength in the parallels between Adam, Eve, Joseph, Mary and Christ, it is hard to see how this correspondence is "perfect." ${ }^{89}$ The reason the allusions to marriage in Gen 2:24 and Matt 19:6 are not more explicit is because it weakens the strength of Irenaeus' economic parallelism. The nuptial bond of union between Adam and Eve does not mirror the mother-child relationship of Mary and Christ. In a recent article, Dunning argues that "sexual difference" is the breakdown in Irenaeus' recapitulative framework, yet this section reveals a more fundamental issue for the symmetry of his ascetic parallelism. ${ }^{90}$ While there is much that is consistent, the essential inconsistency lies in the familial relationships between Adam, Eve, Joseph, Mary and Christ. Irenaeus is not oblivious of this point, which is why he only names Adam outright in his discussion of their respective betrothals. He refers to Mary as having a husband, but omits mention of Joseph's name precisely because he is the exception to the Adam-Christ and Eve-Mary parallelism. ${ }^{91}$ This inconsistency also helps explain the awkward phrasing in this section and the use of the cryptic

\footnotetext{
of Matt 19:6 in the imagery of "what was bound together could not otherwise be undone..." (non aliter quod colligatum est colueretur). Furthermore, the references to the "first union" (primae conjunctiones) or "first bond" (primam... compaginem) in this context are easily understood as images referring to

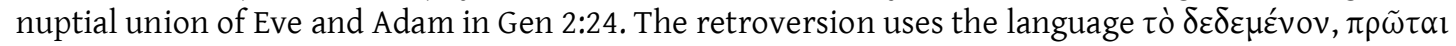

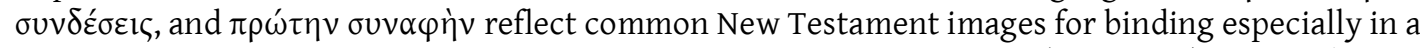

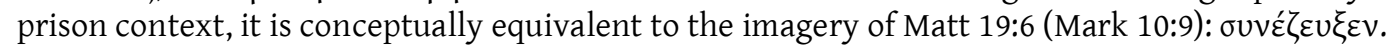
Several of these terms are uniquely concentrated in Paul's body imagery, which suggests that Irenaeus is conflating the marriage imagery with soteriological imagery (cf. Eph 4:3,16; Col 2:19; Col $3: 14 ; c f . A H$ 3.19.7). This explains complicated theological and cryptic imagery of this section; Irenaeus was wrestling with a potential weakness in the symmetry of the espousals of Eve and Mary. For a reference to the difficulty of translating this section see this the notes in the ANF translation of AH 3.22.4.

${ }^{89}$ SC 210.374; Donovan, One Right Reading?, 88.

${ }^{90}$ Dunning, "Virgin Earth," 63.

${ }^{91} \mathrm{AH}$ 3.22.4.
} 
binding imagery. The references to Mary's reversal of the bonds, therefore, should be understood as Irenaeus' attempt to wrestle with the union imagery of Gen 2:24 and Matt 19:6 (alongside Pauline use of body imagery) in relationship to the salvific work of Christ who was born of Mary in light of his economic parallelism. ${ }^{92}$ What is clear is that the second bond (secunda colligatione) that overturns or looses the first bond is not a nuptial "bond" between Mary and Christ, but the union of all humanity in the body of Christ. This is why Irenaeus concludes that Christ (not Mary-but through Mary) was the "first begotten of the dead," becoming in "himself" (ipse) the beginning of those who live contrary to Adam who became the beginning of those who die.

The intertextual references he uses in the context confirm this point and each of these texts is connected by the conceptual idea of "circling back" (recirculationem) or reversal of the disobedience in Gen $3: 6 .{ }^{93}$ He begins with a citation of the Lord's words in Matt 19:30/20:16, “indeed the first shall be last and the last first" (primos quidem nouissimos futuros et nouissimos primos). For Irenaeus, Christ himself is the "last" (nouissimos) who has been made first in the kingdom, because through Christ all have found life. Likewise he cites Psalm 44:17 LXX, "In place of your fathers will be your sons" (Pro patribus nati sunt tibi fili). The son of Adam has taken the place of his father, because the Lord was "born the Firstbegotten of the dead," (Primogenitus enim mortuorum natus Dominus, Col 1:18). Having been resurrected from the dead, he now receives the ancient Fathers into his own bosom (Isa 40:11) and regenerates them back to the life of God. ${ }^{94}$ The climax of this theology of reversal is the recapitulation of all things in Christ. He again mentions the reverse chronology of Luke's genealogy and remarks that just as Adam became the beginning of those who die (though his union with Eve's disobedience), so also has Christ become the beginning of those who find life (by means of Mary's obedience). In general the conceptual imagery of these texts supports Irenaeus' theology of reversal and the overturning of the effects of Adam and Eve's disobedience in paradise. In this way, the Eve-Mary typology is understood in

\footnotetext{
${ }^{92}$ This is also strengthened by the fact that Irenaeus envisions the rite of marriage to cease in the eschatological state. While he uses the marriage imagery for linking salvation history, his ultimate concern is soteriological. Behr, Asceticism, 113; AH 2.33.5.

${ }^{93}$ Behr, Asceticism, 64 n. 96. AH 3.22.4. See also Dial, 132.

${ }^{94} \mathrm{AH}$ 3.22.4. Although, several passages may be in view, Isa $40: 11$ is likely due to the language of "his bosom" (sinum suum) combined with the use of "lambs" (ouem) at the start of the subsequent chapter.
} 
immediate connection to the Adam and Christ typology. The Eve-Mary typology, like all other intertextual relationships, participates in Irenaeus' broader textual concerns.

\subsection{AH 3.23.1-8: The Salvation and the Formation from the Dust}

As we have seen in the preceding sections, Donovan locates a number of chiastic structures throughout $A H$ 3. In $A H$ 3.18.2-3.18.7 Irenaeus outlines the necessity of the Incarnation against the Valentinians and in AH 3.19.1-21.9 he argues for the complete divinity and humanity of Christ against the Ebionites. But Donovan neglects to identify what may be the most important chiasm in AH 3: AH 3.23.1-8. The recognition that the Incarnation was necessary (AH 3.18.2-3.18.7) coupled with the conviction that Christ was both fully human and divine (AH 3.19.1-AH 3.21.9) results in the logical conclusion that humanity, which is recapitulated in the person of Christ, finally participates in salvation, thereby overturning the effects of Adam's disobedience (AH 3.23.1-8). Moreover, while AH 3.22.1-4 concerns the Pauline analogy between Adam as the formation from the dust and Christ's virgin birth, $A H$ 3.23.1-8 is oriented around the contrary nature of Adam's disobedience and Christ's obedience. The chiasm in AH 3.23.1-8 is the natural theological and structural climax of Irenaeus' theology of recapitulation and polemical argument in $A H 3 .^{95}$ As we will see, Adam's contrition before God in relation to Cain's insolence forms the centerpiece of the chiasm, which becomes a convenient paradigm for Irenaeus' distinction between the soteriological standing of the faithful and his opponents. Alluding to this section in particular, Steenberg suggests that if recapitulation is understood as a "coherent doctrine," it was necessary that the Word of God, the image after whom Adam was formed, become physical. ${ }^{96}$ However, in Irenaeus' doctrine of recapitulation it was also necessary, as this chiasm demonstrates, that the work of Christ overturn the effects of Adam's disobedience and destroy sin, death, and the devil.

\footnotetext{
${ }^{95}$ In $A H$ 3.23-24 he transitions into an 'epilogue' discussing the nature of the church and introducing the themes discussed in AH 4. Donovan, One Right Reading?, 93.

${ }^{96}$ Steenberg, Irenaeus, 136. A summary version of this section will be published separately as Stephen O. Presley, "The Lost Sheep who is Found: Irenaeus' Intertextual Reading of Genesis 3 in Adversus Haereses 3.23.1-8," StuPat 51, 2011.
} 


\subsubsection{Introduction: Gen 1-3 in the Chiasm of AH 3.23.1-8}

Turning to the chiasm itself, $A H$ 3.23.1-8 contains a web of textual allusions oriented by the events of Gen 3 and, in particular, the disobedience of Adam and Eve in Gen 3:5. Although Irenaeus is clearly interpreting the whole narrative of Gen 3, he does not cite every text and his reading alters the flow of the original. He also links a variety of other scripture references with his reading of Gen 3 as he reinterprets these passages in light of his theological polemic. Below is an overview of the main themes in each segment of the chiasm, along with the scriptural allusions present in each paragraph:

A. AH 3.23.1: The Serpent's Deception and the Hope of Salvation (Gen 1:26, Gen 3:5, Matt 12:29, Luke 15:4-7 ${ }^{97}$, Luke 19:10, Ac 1:7, 1 Cor 15:47, Eph 1:5, 9, $2 \operatorname{Tim} 1: 10)$

B. AH 3.23.2: Adam Requires Salvation (Gen 1:26; Matt 12:2998)

C. AH 3.23.3: God Curses Adam, Eve and the Serpent (Gen 3:14, Gen 3:16, Gen 3:17-19, Matt 25:41)

D. AH 3.23.4: Cain's Insolence (Gen 4:7-8, Gen 4:9, Gen 4:11, Matt 23:35)

D'. AH 3.23.5: Adam's Humility (Gen 3:8, Gen 3:7, Gen 3:10, Gen 3:21, Gen 3:13, Prov 1:799)

$C^{\prime}$. AH 3.23.6: God's Compassion in Adam's Expulsion: Gen 3:2324 , Rom 6:2, 10)

B'. AH 3.23.7: The Protoevangelium Fulfilled in Christ (Gen 3:15, Psalm 90:13 LXX, Luke 10:19, Rom 5:12, 17, 1 Cor 15:26, 1 Cor 15:54-55, Gal 3:16, Gal 3:19, Rev 20:2/12:9)

$\mathrm{A}^{\prime}$. AH 3.23.8: The Continuation of the Serpent's Actions (Gen 3:5, Luke 15:4-7, 1 Cor 15:22, Rom 5:20)

Every paragraph contains allusions to Gen 3 (or Gen 4 in the case of AH 3.23.4) and, although certain texts are rearranged in an unconventional manner, there is an obvious appreciation for the general chronological structure of the events alongside

\footnotetext{
${ }^{97} \mathrm{cf}$. Matt 18:12-14

${ }^{98} \mathrm{cf}$. Luke 11:21-22

${ }^{99} \mathrm{cf.Pv}$ 9:10 and Psalm 111:10
} 
a Christological and allegorical reinterpretation of the whole narrative of Adam and Eve's disobedience and expulsion from paradise. Having established the Christological basis for recapitulation in the previous section (AH 3.19.1-AH 3.22.4) the arrangement takes on a more anthropological turn and begins with deception of the serpent (Gen 3:5), followed by the expressed need for salvation for the one created in the image and likeness of God (Gen 1:26), the curses (Gen 3:14,16-19), Cain's response (Gen 4:7-11), Adam's response (Gen 3:7-13,21), the preparation for salvation in the expulsion (Gen 3:23-24), the prophesy of salvation (Gen 3:15), and the ongoing deception of the serpent in the form of Tatian and his disciples (Gen $3: 5)$.

Summarizing the relationship between the corresponding sections, Gen 3:5 frames the chiasm, which is found in A and A', and not only reflects Satan's work of deception in paradise, but also the teaching of Tatian, a contemporary to Irenaeus. The sections of $B$ and $B^{\prime}$ describe the means of salvation for the one created in the image and likeness of God in Gen 1:26, which is predicted in the protoevangelium of Gen 3:15 cited in $B^{\prime}$. This theologically unites the passages of Gen 1:26 and Gen 3:15 in Irenaeus' concept of salvation and ultimate triumph over the activity of Satan. Adam received the prophecy of salvation in Gen 3:15, so although the one created in the image and likeness of God is now destined to death, he will be vivified once again when the Son of God destroys death and restores the imago Dei. The sections of $C$ and $C^{\prime}$ concern the cursing of Adam, Eve, and the serpent in Gen 3:14, Gen 3:16, and Gen 3:17-19 and Adam and Eve's expulsion from paradise in Gen 3:23-24. Irenaeus notes that the curse was not against Adam personally but against the ground; instead the curse in its fullness fell upon the serpent. ${ }^{100}$ This is evident when Irenaeus discusses the curses in reverse order, so he begins with Adam in Gen 3:17-19, then Eve, and then the serpent in Gen 3:14. God also compassionately drove Adam out of paradise so that he might receive salvation. The centerpiece of the chiasm is the comparison of Cain and Adam in D and D', which casts the murderous actions of Cain in Gen 4:7-8, Gen 4:9, and Gen 4:11 as the inversion of Adam's humbling actions in Gen 3:8, Gen 3:7, Gen 3:10, Gen 3:21, and Gen 3:13. This section reflects the focal point of Irenaeus' argument and his reading of Gen 3:5. Irenaeus implores the faithful to withstand the deceptions of the heretics, who are obstinate

\footnotetext{
${ }^{100}$ cf. Epid 16.
} 
like Cain, and instead choose to humble themselves before God as Adam and Eve in paradise. In doing so, the faithful will find salvation from Christ who overcomes the power of the serpent. This imagery of conquering the serpent in the opening and concluding paragraphs of the chiasm utilizes the imagery of lost sheep in Luke 15:47 along side Gen 3:5 to illustrate how the work of Christ overturns the deception of the serpent and restores the lost humanity back to God. This summary, however, only scratches the surface of the more subtle nuances of Irenaeus' intertextual reading of Gen 3. Below we provide a closer evaluation of each individual section and the textual and theological interrelationships he fashions with Gen 3.

\subsubsection{AH 3.23.1: (A) The Serpent's Deception and the Hope of Salvation (Gen $1: 26$, Gen 3:5)}

As we have shown, the bookends of the chiasm (A and $A^{\prime}$ ) allude to the activity of the serpent that deceived Adam and Eve in paradise (Gen 3:5). This theological clustering of texts are bound by common vocabulary and the imagery of Christ's restoration and recapitulation of Adam's disobedience. ${ }^{101}$ The Bishop of Lyon reminds the reader that this one who was deceived is the same one who was created in the image and likeness of God (Gen 1:26), but through the tantalizing propositions of serpent, Adam became a "vessel in his [Satan's] possession" (enim possessionis eius vas, cf. Matt 12:29). The humanity lost in Adam is, for Irenaeus, the lost sheep of Luke 15:4-7. Responding to Adam's predicament, the Lord has come to seek out and save lost humanity (Luke 19:10). He separates out the two verbs of Luke 19:10

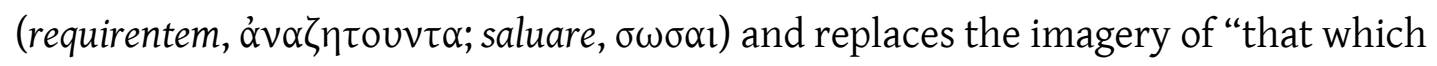

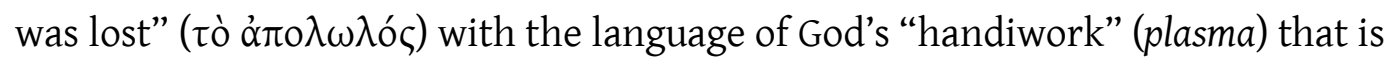
fashioned in the image and likeness of God (Gen 1:26). However, this soteriological recovery was not the work of the Lord alone. The power (Acts 1:7) and will (Eph 1:5, 9) of God the Father so precisely arranged the divine economy to ensure the Word of God would successfully reverse the effects of Adam's disobedience. Irenaeus even draws the logical conclusion that if humankind, who had been created by God to live, were not restored to life then Satan would have prevailed over the will of God. Like the imagery of the lost sheep, the strong man is Satan who has captured the "vessel" (uasa) of humankind and subjected them to the power of death (Matt

\footnotetext{
${ }^{101}$ AH 3.19.3 combines Gen 2:7, Luke 15:4, and Eph 4:9 to draw a similar conclusion.
} 
12:29). There is no question that God was patient in the recovery of Adam, but recapitulation of Adam was fully realized when at last the "second man" (secundum hominem, 1 Cor 15:47) bound up the strong man who had ensnared Adam and spoiled his goods (Matt 12:29). He even parallels the spoiling of goods with the "emptying of

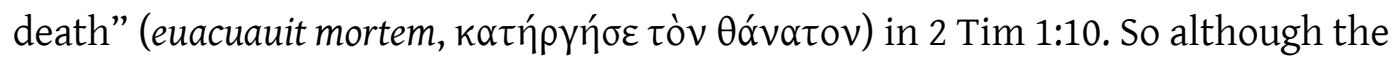
first Adam (1Cor 15:47) became a vessel in the possession of Satan when the serpent deceived the first couple and under the pretext of becoming gods (Gen 3:5), the second Adam bound up Satan and restored the humankind to life.

\subsubsection{AH 3.23.2: (B) Adam Requires Salvation (Gen 1:26)}

As he alluded in the previous section, Adam is the first-formed human person created in the image and likeness of God (Gen 1:26). By logical extension all humanity derives its form and substance from Adam's formation. Although he does not name Tatian in this context, his polemic against him is evident. Since Adam is God's original creation, it is only fitting and just that the extant of the Lord's salvific work, contra Tatian, should extend all the way back to the beginning. Irenaeus rejects the notion that some of Adam's progeny would find salvation, but not Adam himself. As an illustration he uses the example of a subjugating, hostile force, borrowing from Matt 12:29. It would be simply unjust, Irenaeus reasons, if the liberators freed only the children from captivity and not their fathers who were first enslaved. In the same way God, who is neither powerless nor unjust, would not release the children of Adam and not Adam himself. ${ }^{102}$ Therefore, all of Adam's posterity with Adam himself requires salvation.

\subsubsection{AH 3.23.3: (C) God Curses Adam, Eve and the Serpent (Gen 3:14, Gen 3:16, Gen 3:17-19)}

With Adam's and his descendents in need of salvation, the third section of the chiasm concerns the cursing of Adam, Eve, and the serpent. Even though Adam transgressed the commands of God (Gen 3:5), Irenaeus points out that technically God did not curse Adam personally (Gen 3:17-19), but the earth that God had used to form Adam (Gen 2:7). For the reason, Adam must work the ground and in the end return to the substance from which he was formed (Gen 3:19). Implicit in this

\footnotetext{
${ }^{102}$ AH 3.23.2.
} 
allusion to Adam's curse is the penalty of death for Adam's disobedience against God's command in Gen 2:16-17. He also mentions Eve in passing who receives punishment for her disobedience (Gen 3:16). However, his primary purpose is to convey that Satan will receive the full measure of God's retribution when he is cast into the eternal fire (Matt 25:41). By reversing the literary patterns of the curses, he accentuates that the fullness of the curse fell upon the serpent. In addition, the common language of "accursed" ( $\alpha \tau \eta \rho \alpha \mu \varepsilon v o l) ~ l i n k s$ Gen 3:14 and Matt 25:41. ${ }^{103}$ Alluding to this intertextual relationship, Irenaeus even concludes the curse of Gen 3:14 indicates the eternal fire was not originally prepared for Adam, but for the one who led him astray. ${ }^{104}$

\subsubsection{AH 3.23.4: (D) Cain's Insolence (Gen 4:7-8, Gen 4:9, Gen 4:11)}

The centerpiece of the chiasm (D and $\mathrm{D}^{\prime}$ ) is the typological contrast of the murderous actions of Cain in Gen 4:7-9 and Gen 4:11, with the humbling actions of Adam in Gen 3:7-8, Gen 3:10, Gen 3:21, and Gen 3:13. Satan's condemnation in the conclusion of AH 3.23.3 is liked with the discussion of Cain who, according to Irenaeus, did not make "an equitable division" (recte diuisisset) of his sacrifice, but instead was controlled by envy and malice believing "he could domineer over him" (posse dominari eius). Irenaeus links Cain's desire to "domineer" (dominari) over his brother Abel with the serpent's actions in paradise. The actions of Cain are a manifestation of his state of mind that escalates into his contemptuous response to God, saying, “am I my brother's keeper?” (numquid custos fratris mei sum ego?, Gen 4:9). His retort is both "insolent" (audaciter) and "irreverent" (irreuerenter) and exposes the height of Cain's arrogance. He actually believes, Irenaeus infers, that he could "refute" (frustrari) the God who created all things. He views the act of insolence toward God and even greater sin than the murder of Abel, because it manifests Cain arrogant state of mind. Therefore, Irenaeus envisions Cain as a kind of type of the serpent and his actions as manifesting the motivations of the serpent. ${ }^{105}$

\footnotetext{
${ }^{103}$ AH 3.23.3.

${ }^{104} \mathrm{AH}$ 3.23.3.

${ }^{105}$ In a general sense, this central parallelism points to the centrality of martyrdom in Irenaeus' thought and his emphasis on the martyr as the perfected Christian. See Real Tremblay, "Le martyre selon saint Irénée de Lyon," StudMor 16 (1978): 167-189, 177; Behr, Asceticism, 78-9.
} 


\subsubsection{AH 3.23.5: (D') Adam's Humility (Gen 3:7-8, Gen 3:10, Gen 3:13, Gen 3:21)}

Whereas Cain was murderous and insolent, Adam's actions were "in every way contrary" (omnia in contrarium). Adam, Irenaeus comments, was seized by fear in Gen 3:7-8 and feels unworthy to appear before God in the midst of his disobedience. While Cain (and the serpent) believed he could challenge God, Adam was overcome with the fear of God (Prov 1:7). He concealed himself in shame and refused to speak with God (Gen 3:8). Moreover, while Cain was obstinate, Adam shows himself repentant when he grids himself with the fig leave in Gen 3:7. Irenaeus suggests that Adam specifically chose this leaf because the irritation of the plant reflects the gravity of his offense. ${ }^{106}$ Kugel and Greer suggest that Irenaeus reads Adam's shame as a "necessary stage in the human education and growth." ${ }^{107}$ Adam loses his "childlike" state and cultivates a "lustful propensity of the flesh." ${ }^{108}$ However, the reference to Prov 1:7 and the act of covering themselves with fig leaves, as Behr suggests, is a self-imposed penitential act whereby Adam denied himself God's gift of growth and increase. ${ }^{109}$ Steenberg, goes so far as to characterize the nature of the post-transgression economy as oriented toward repentance. ${ }^{110}$ The comparison with Cain and the broader chiastic framework enhances Steenberg's thesis by linking the opposing actions of Cain and Adam to behaviors of the heretics. Irenaeus' reads Adam's contrition in relationship to Cain's (and the serpents') rebellion against God.

Whereas God curses Cain and the serpent, according to Irenaeus, God responds to Adam's humility with mercy by removing the fig leaves and covering him with "garments of skins" (tunicas pellicias, Gen 3:21). The Valentinians, as Irenaeus has shown, use this text to illustrate the final stage of human formation as the sensible element of the human form. ${ }^{111}$ Behr argues that the garments of skin simply refer to the life of Adam and Eve in apostasy, so for Irenaeus there is no special allegorical meaning in the garments. ${ }^{112}$ Irenaeus also avoids any extended reflection upon this passage and does not mention it elsewhere. Thus, Irenaeus

\footnotetext{
${ }^{106}$ AH 3.23.5.

${ }^{107}$ Kugel and Greer, Early Biblical Interpretation, 167-68.

${ }^{108}$ AH 3.23.5; Behr, Asceticism, 119.

${ }^{109}$ Behr, Asceticism, 118-9; Steenberg, Irenaeus, 181.

${ }^{110}$ Steenberg, Irenaeus, 180.

${ }^{111}$ AH 1.5.5.

${ }^{112}$ Behr, Asceticism, 119.
} 
responds the Valentinian interpretation of this passage by merely reading the text within the narratival context of Adam's disobedience. ${ }^{113}$

Irenaeus also points out that though God sought after and interrogated Adam and Eve (Gen 3:9-11), there was no need to interrogate the serpent because God already knew he was the primary instigator of the ordeal. ${ }^{114}$ God detested the serpent for his actions and, for this reason, the full retribution of God fell upon him. On the other hand, God showed a propensity for compassion toward Adam. ${ }^{115}$

\subsubsection{AH 3.23.6: ( $\left.C^{\prime}\right)$ God's Compassion in Adam's Expulsion (Gen 2:9, Gen 3:23-24)}

In $A H$ 3.23.6, Irenaeus continues his discussion of God's mercy upon Adam and characterizes his expulsion from paradise in Gen 3:23-24 and his dissolution of the flesh in Gen 3:19 as an act of compassion. He rejects the Gnostic suggestion that this expulsion was related to the knowledge Adam gained from eating of the tree. Instead, God removed him from the tree of life because God desired that humankind not remain forever in a state of sin. He links the "tree of life" (lignum uitae, Gen 2:9) and the one who "lives to God" (uiuere Deo, Rom 6:10) to argue that to be in the presence of the tree of life is to have life. God removes the first couple from the tree of life and erects a boundary to sin in death, because sin is destroyed in death when the flesh dissolves back into the earth (Gen 3:19) and sin ceases (Rom 6:7). ${ }^{116}$ Behr notes here the "pedagogical aspect" of death in Irenaeus' thought that casts Adam's subjection to death as an act of mercy. ${ }^{117}$ While the positive evaluation of death is found in other patristic writers, the pedagogical aspect of death is peculiar to Irenaeus. In the framework of the chiasm, even though God curses the first couple in Gen 3:14-16 and they are expelled from paradise and subject to death, all of these acts mercifully prepare Adam and Eve to receive life once again.

\subsubsection{AH 3.23.7: ( $\left.\mathrm{B}^{\prime}\right)$ The Protoevangelium Fulfilled in Christ (Gen 3:15)}

Prior to Adam and Eve's expulsion from paradise, God supplied them with the prophecy of salvation in Gen 3:15. The description of enmity between the serpent

\footnotetext{
${ }^{113} \mathrm{AH} 1.5 .5, \mathrm{AH} 1.18 .2$.

${ }^{114}$ AH 3.23.5.

${ }^{115}$ AH 3.23.5

${ }^{116}$ AH 3.23.6. cf Theophilus Ad. Auto 2.26.

${ }^{117}$ Behr, Asceticism, 52.
} 
and the seed characterizes, for Irenaeus, the nature of the postlapsarian economy. The opening lines of $A H$ 3.23.7 convey intertextual relationships between Gen 3:15, Luke 10:19, and Gal 3:16,19 united by the language of "serpent," (serpentem) "enemy," (inimici) "seed," (semen) and the verb “tread upon" (calcare). ${ }^{118}$ Irenaeus' allusion to Gen 3:15a is a simplified version of the initial two parallel statements in the LXX, and he converts the future tense "will put" ( $\theta \eta \dot{\sigma} \sigma \omega)$ into a perfect tense "has put" (posuit). ${ }^{119}$ For Irenaeus, the prophecy of Gen 3:15 has been fulfilled, in part, though the first advent of Christ. The parallel clauses of Gen 3:15b: "He will

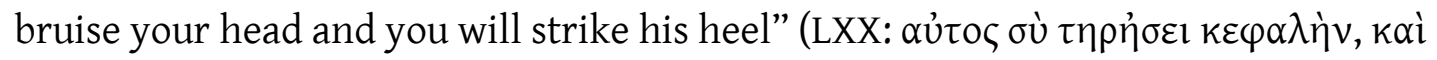

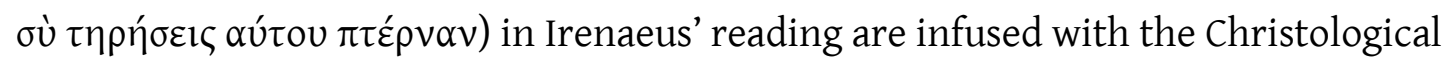
imagery of Luke 10:19 and Gal 3:16,19. Referring to Christ, Irenaeus converts the future tense of "he/you will bruise" ( present passive "he is bitten" (mordetur) and "he has the power to tread upon" (potente calcare). This is the influence of Luke 10:19 that connects the authority of Christ over the power of Satan through the parallel imagery of "serpent" (serpentem) and "enemy" (inimici). The economic poles of the struggles between the seed and the serpent in Gen 3:15 and Luke 10:19 suggests, for Irenaeus, the struggle has persisted throughout salvation history. He speaks of the serpent's activity as "impeding the steps of humankind" (interpediente ingressus hominis) which offers a

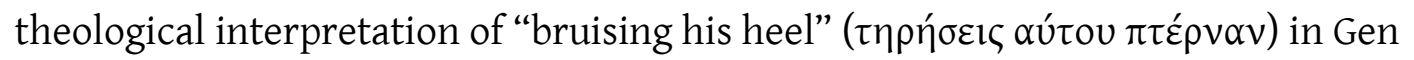
3:15. The deception of the serpent that began in paradise continues to inhibit the progression of salvation history and aims to make God's creatures disobedient toward their Creator. ${ }^{120}$

The mutual enmity between the serpent and seed, according to Irenaeus, lasts until the appointed seed comes who has the power to overcome the enemy (Gal 3:16). This interpretation envisions Gal 3:19 and an implied allusion to Gal 3:16 as the fulfillment of the second clause of Gen 3:15b. For Irenaeus, the seed of Gal 3:19 is, alluding to prophecy of Gen 3:15, "predestined to tread upon his head" (praedestinatum calcare caput eius) which also links the infinitive "to tread upon" (calcare) drawn from Luke 10:19. ${ }^{121}$ The added allusion to Gen 3:16 also identifies the

\footnotetext{
${ }^{118}$ AH 3.23.7.

${ }^{119}$ AH 3.23.7.

${ }^{120}$ A similar concept is expressed in $A H$ 3.23.6, where God is said to "gradually" (sensim) have compassion upon humankind.

${ }^{121}$ AH 3.23.7
} 
parallels between prophecy given to Eve and child who was "born of Mary" (fuit partus Mariae). ${ }^{122}$ Therefore, the way Irenaeus weaves Gen 3:15, Luke 10:19, Gal 3:19, and Gal 3:16, exposes the conflation of texts through his theological hermeneutic. We have seen in AH 3.23.2 that Adam, who was created in the image and likeness of God, requires salvation and Irenaeus balances this assertion with the fulfillment of Satan's demise in Gen 3:15.

Finally, the concluding portion of AH 5.23.7 presents a string of theological, narratival, and linguistic intertextual connections to confirm the fulfillment of Gen 3:15 in Christ. This series of intertextual allusions includes: Psalm 90:13 LXX, Rom 5:12, 17, Rev 20:2/12:9, Luke 10:19-20, 1 Cor 15:26 and 1 Cor 15:54-55. This network of scriptures are textual buttresses for Irenaeus' theological connections between the protoevangelium and the Christ event. First, he depicts sin's activity in anthropomorphic imagery as overpowering and subjecting humankind to death (Rom 5:12,17). In relation to this imagery, he interprets the prophecy of Psalm 90:13 LXX, "you will tread upon the asp and basilisk" (Super aspidem er basiliscum ambulabis), as the destruction of the sin and death inflicted by the serpent in paradise. He make this connection explicit when he links the "dragon" (draconem) in Psalm 90:13 LXX with the Antichrist, or "dragon that old serpent" (draconem illum serpentem uetustum) of Rev 20:2/12:9. Though the fulfillment of Gen 3:15 and Psalm 90:13 LXX, the Antichrist-dragon-serpent that originally inflicted sin and death upon Adam is at long last subject to the "power of humankind" (subiciens potestati hominis) in the person of Christ and "trodden down" (adligans, Luke 10:19). This act of treading upon the serpent's head in Gen 3:15, Psalm 90:13 LXX, and Luke 10:19 is fully realized in Rev 20:2/12:9, where the serpent of old is put down and cast away. The implication of Christ's work is that death has been destroyed and humankind has been liberated from the power of the serpent that subdued Adam and Eve in the Garden (1 Cor 15:26, 54-55). The destruction of death in 1 Cor 15:26, 54-55 is the consummative fulfillment of Gen 3:15 and the essential description of the salvation of humankind. For Irenaeus, Adam's “salvation is death's destruction” (enim salus euacuatio est mortis). This section brings resolution to the human need for salvation mentioned in the corresponding section of the chiasm and the exposes the complexities of his intertextual reading of Gen 3. The whole section is contingent

\footnotetext{
${ }^{122}$ Although other passages may be influencing this title the connections to Gal 3:19 and Gen 3:15 support this allusion to Gal 3:16. cf. Matt 1:16, 20; Luke 2:5.
} 
upon Gen 3:15, which according to Irenaeus lays the groundwork for the understanding of the work of Christ and the overcoming of sin, death, and the devil.

\subsubsection{AH 3.23.8: (A') The Continuation of the Serpent's Actions (Gen 3:5)}

In his closing section, Irenaeus returns again to his polemical argument. According to Irenaeus, Tatian is promoting the teaching that Adam himself is excluded from salvation. Summarizing Tatian's views, Petersen writes, “The key to Tatian's system is gnosis, "knowledge"'... although Adam had knowledge of God, he -through freewill- rejected it. ${ }^{123}$ As a result, Adam chose to reject the knowledge of God and is excluded from salvation, but those who desire to grasp the true knowledge of God may find salvation in gnosis. Irenaeus responds to this train of thought by arguing that if Adam is not saved then all of Adam's posterity remains in a state of perdition. For Irenaeus, on the other hand, the lost sheep of humanity who had sinned through disobedience are found in the person of Christ (Luke 15:4-7). The issue for Tatian, according to Irenaeus, is the rejection of these intertextual connections that demonstrate clearly how the power of God has prevailed over the serpent (Rom 5:20).

The closing lines of $A H$ 3.23.8 contain a final allusion to Gen 3:5, which knits together the whole structure of the chiasm (A and $\mathrm{A}^{\prime}$ ) and parallels the activity of the serpent with the activity of Tatian and his disciples. Those who promote the doctrines of Tatian, according to Irenaeus, are the contemporary manifestations of the serpent's deceptive activity. As the serpent led Adam and Eve astray by means of deception and falsehood, Tatian and his disciples reveal themselves as "patrons of the serpent and of death" (aduocatos se serpentis et mortis ostendunt). ${ }^{124}$ However, just as the serpent "accomplished nothing" (nihil profecit) when he persuaded Adam and Eve to sin in Gen 3:5, Tatian and his disciples accomplish nothing in their exclusion of Adam's salvation. ${ }^{125}$ Therefore, according to Irenaeus, both Adam and the faithful face the same active deception of the serpent. Just as Adam and Eve stood beneath the tree in paradise and gave way to the temptations the serpent, so also do the faithful stand before the doctrines of Tatian and must choose to endure the intellectual enticements. For Irenaeus, the true knowledge of God is found in the

\footnotetext{
${ }^{123}$ Petersen, "Tatian the Assyrian," 151.

${ }^{124}$ AH 3.28.8.

${ }^{125}$ AH 3.28.8.
} 
work of Christ who has fulfilled the prophecy of Gen 3:15 and enabled the salvation of humankind. The faithful should also learn from Adam's mistake and, rather than becoming obstinate like Cain (who also manifests the attitude of the serpent), model Adam's contrition before God. ${ }^{126}$

\subsubsection{Conclusion}

In conclusion, the chiasm of $A H$ 3.23.1-8 centers on his reading of the events in Gen 3 and functions as the climax of Irenaeus' recapitulation argument spanning $A H$ 3.18.2-3.22.4. The Incarnation and recapitulation of all things in Christ effects the salvation of humankind and the destruction of sin, death, and the devil. Irenaeus' reading of Gen 3 alters the chronology of the original narrative in order to demonstrate his theological and Christological application of the events. For Irenaeus Gen 3 could only be properly read within carefully constructed scriptural networks of interrelated texts. These networks include theological arrangements of the narrative in Gen 3, as well as tissues of texts spanning both Testaments. These networks are bound together by common imagery and theological concepts. The entire chiasm is framed with the activity of the serpent in the narrative of Gen 3:1-5 and the corresponding teachings in the doctrines of Tatian (A and $\left.A^{\prime}\right) .{ }^{127}$ Following Adam's disobedience, both he and his posterity require salvation. This is prophesied in Gen 3:15 and fulfilled in the person of Christ (B and B' $).{ }^{128}$ Though Adam, Eve, and the serpent were subject to God's curses, the full measure of his retribution fell upon the serpent and Adam and Eve were expelled from paradise in Gen 3:23-24 to prepare them for salvation ( $C$ and $\left.C^{\prime}\right) .{ }^{129}$ Throughout the course of the divine economy, the serpent has been striving to impede the progression of salvation for God's people (Gen 3:15). In the climax of the chiasm, Irenaeus compares the antithetical actions of Cain and Adam in response to God (D and D'). ${ }^{130}$ When God questioned Cain he was obstinate (Gen 4:9), but Adam's humbling actions were in every way contrary (Gen 3:7-8). In the same way, Irenaeus implores the faithful not to be obstinate before God like Cain, but humble as Adam. In doing so, he argues, the

\footnotetext{
${ }^{126}$ AH 3.23.4-5.

${ }^{127} \mathrm{AH} 3.23 .1,8$.

${ }^{128}$ AH 3.23.2,7.

${ }^{129}$ AH 3.23.3,6.

${ }^{130}$ AH 3.23.4-5.
} 
faithful will find salvation from the one who has trampled upon the serpent's head and restored the lost sheep of humanity to the fold of life.

\subsection{AH 3.24.1-2: The Church, the Spirit, and the Knowledge of God}

In the closing chapters of $A H$ 3, Irenaeus is confident he has exposed the errors of his opposition and defended nature of God as Creator, Christ as fully divine and human, and the comprehensive salvific work of Christ epitomized in the preaching of the church. He also believes he has done so from the whole testimony of the apostles and prophets in the scriptures including the "beginning, the middle and the end" (per initia et medietates et finem). ${ }^{131}$ The Bishop of Lyon identifies the content of the apostolic testimony as the unfolding of the redemptive history, which he describes as a perfect process that guides the faithful towards salvation. This imagery leads to an illustrative application of Gen 2:7 to the work of the Spirit in the church. Conflating Gen 1:26, Gen 1:28, and Gen 2:7, he also characterizes the knowledge of God as Creator as the fundamental feature of the preaching of the church.

\subsubsection{AH 3.24.1: The Church, the Body and the Spirit (Gen 2:7)}

AH 3.24.1 adds the pneumotological conclusion to Christ's recapitulative work. Christ unites God to the human formation in himself and then imparts the Spirit as the means to vivify the mortal flesh of all the faithful in the church. ${ }^{132} \mathrm{He}$ imagines the human person as a "vessel" (vaso, Matt 12:29) containing the "precious deposit" (eximium... depositum) of the faith of the church. ${ }^{133}$ The change of the inflection in the participles from perfect passive to present active signifies the tension in Irenaeus' thinking between the faith of the church that "has been entrusted" (creditum est) and the Holy Spirit that "has been deposited" (deposita est) with the people of God who are "receiving" (percipientia) them. By means of the Holy Spirit, the faith of the church continually renews the life of the vessel preserving the youthful nature of the vessel itself. Conflating the language of the "gift of God" (Dei

\footnotetext{
${ }^{131} \mathrm{AH}$ 3.24.1. In the context the beginning middle and end appear to be the Old Testament, the Apostolic writings and the Church. cf. Laws of Plato IV, 715,

${ }^{132}$ Behr, Asceticism, 66.

${ }^{133}$ As we have seen vaso is a common Irenaean image: $A H$ 3.8.2, $A H$ 3.18.6, $A H$ 3.23.1, $A H$ 4.33.4, and $A H$ 5.22.1.
} 
munus) from Eph 2:8 with the creation scene of Gen 2:7, Irenaeus imagines the impartation of the breath of God in Gen 2:7 as the same manner of the gift of the Holy Spirit being imparted to the church. ${ }^{134}$ Just as the breath of God enlivened the formation of Adam in Gen 2:7, the gift of faith entrusted to the church enlivens the faithful. ${ }^{135}$ This life is also sustained though the operations of the Spirit in 1 Cor 12:11, who are the apostles, prophets and teachers mentioned in 1 Cor 12:28. Those who remain outside the church, again echoing the imagery of Gen 2:7, "defraud themselves of life" (fraudant a uita). ${ }^{136}$

\subsubsection{AH 3.24.2: Knowledge of the Creator (Gen 1:26, Gen 1:28, Gen 2:7)}

In $A H$ 3.24.2 Irenaeus makes a final parting critique by suggesting the Gnostics reject a priori any conception of God within grasp of human knowledge. According to Irenaeus, the fundamental knowledge of God accessible to the human mind is the understanding of God as Creator, which Behr terms the "pedagogy of the economy." ${ }^{137}$ In making this assertion, Irenaeus implies his Gnostics opponents reject the basic premise of all reality, the knowledge of the God revealed in the formation of humankind. In the midst of this polemic, Irenaeus draws together a network of passages that insist the knowledge of God accessible to all is the knowledge of the God, "who created [Gen 1:26] and formed [Gen 2:7a] and breathed into us the breath of life [Gen 2:7b] and nurtures us through creation [Gen 1:28], strengthening us by His Word [Psalm 32:6 LXX], and binding all things together in His Wisdom [Prov 8:30], this is who is the one true God" (qui fecit et plasmauit et insufflationem uitae insufflauit in eis et per conditionem nutrit nos, Verbo suo confirmans et Sapientia compingens omnis, hic est qui est solus uerus Deus). ${ }^{138}$ For Irenaeus, the concern is the connection between the Creator and the creature and the knowledge of God's act of creation, not necessarily God's “greatness" (magnitudinem) or even God's "nature" (substantiam). ${ }^{139}$ Instead, this narratival arrangement of creation texts is

\footnotetext{
${ }^{134}$ AH 3.24.1.

${ }^{135}$ In the remaining portion of $A H 3.24 .1$ continues to describe the deposit (deposita est) of the Holy Spirit into the church. He characterizes the work of the Spirit with three aspects drawn from other texts: "pledge of incorruption" (arrha incorruptelae) in Eph 1:14, "confirmation" (confirmatio) in Col 2:7, and "ladder of ascent" (scala ascensionis) in Gen 28:12.

${ }^{136} \mathrm{AH}$ 3.24.2. Connecting the "body" imagery envisions the Spirit as nourishment from the Mother's breast and a radiant fountain. $c f .1$ Thess 2:7, Psalm 22:9, Luke 11:27.

${ }^{137}$ Behr, Asceticism, 67.

${ }^{138}$ AH 3.24.2.

${ }^{139}$ AH 3.24.2.
} 
bound up with the identity of God and the nature of God's relationship to humanity. The movement from Gen 1:26, Gen 2:7, Gen 1:28, Psalm 32:6 LXX, and Prov 8:30 is not an unusual cluster of texts for Irenaeus. ${ }^{140}$ The verb fecit refers to the act of creation in the image and likeness of God (Gen 1:26), while plasmauit depicts the act of forming Adam from the dust (Gen 2:7). The remaining portion of Gen 2:7b is cited in the reference to the breathing in of the breath of life. The phrase "nurtures us through creation" (et per conditionem nutrit nos) is an echo of Gen 1:28 that describes the growth and maturity of humankind in and through what is created. ${ }^{141}$ This connection points to the creation texts Psalm 32:6 LXX and Prov 8:30 and described the "strengthening" (confirmans) of the Word and the "binding all things together" (compingens omnia) in Wisdom. ${ }^{142}$ The notions of strengthening and binding are the economic actions of the Son and the Spirit aimed at progressing the humanity toward their appointed salvation. This is why Irenaeus considers Gnostics to produce errant aberrations of the text, because they reject the very basic knowledge of God and the "light" (lumen) that illuminates the understanding of God as Creator. ${ }^{143}$

\subsection{Conclusion}

With the close of $A H 3$, Irenaeus has completed the first summary of his own theological system in response to the heretics. The contribution of Gen 1-3 serves to support the activity of God from creation to glorification. First, as we have seen before, Irenaeus coordinates texts in a narratival relationship. This includes a telescoped summary of salvation history in AH 3.3.3 that begins with allusions to creation and the description of the covenantal relationship, including the Adamic covenant, in $A H$ 3.11.8. Irenaeus provides no substantive commentary on these texts, but simply arranges them in a narrative framework to depict the continuity of salvation history.

\footnotetext{
${ }^{140} \mathrm{cf.}$. AH 2.28.1; AH 3.3.3.

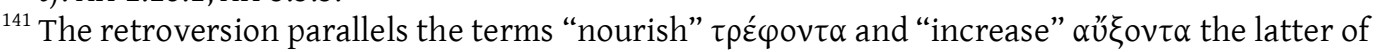
which is the same term used in Gen 1:28 LXX.cf. Epid 11, 14; AH 3.10.3; AH 3.22.4; AH 4.11.1

${ }^{142}$ Although he is not explicit, the connection of these texts with the creation passages is reminiscent of the use of the hands imagery. The "Word" and the "Wisdom" are active in the formation and ordering of creation.

${ }^{143}$ AH 3.24.2; Behr, Asceticism, 87, 110-12.
} 
Second, Irenaeus uses Gen 1-3, alongside other texts, to order or structure his work. This is most evident in a series of chiasms he forms in the latter portions of the book. The texts of Gen 2:5 and Gen 2:7 frame the chiasm in AH 3.18.1 and AH 3.18.7, and Gen 2:7 and Gen 3:1-8 contribute to the first part of the chiasm in $A H$ 3.19.3 and $A H$ 3.20.1. The most developed organizational function of Gen 1-3 and the climax of his recapitulative argument is found in AH 3.23.1-8 with the theological arrangement of the narrative of Gen 3-4. Gen 3:5 frames this chiasm as a whole, but the intervening sections of the chiasm draw from an array of Genesis texts including: Gen 1:26, Gen 3:7-8, Gen 3:10, Gen 3:13, Gen 3:14, Gen 3:15, Gen 3:16, Gen 3:17-19, Gen 3:21, and Gen 3:23-24. In addition, Irenaeus uses a host of intertexts to interpret these passages including: Gen 4:7-8, Gen 4:9, Gen 4:11, Matt 12:29, Matt 25:41, Psalm 90:13 LXX, Prov 1:7, Luke 10:19, Rom 5:12, 17, Rom 6:2, 10, 1 Cor 15:26, 54-55, Gal 3:16, and Rev 20:2. The whole arrangement completes Irenaeus' theology of recapitulation, and reveals the Christological fulfillment of the prophecy of Gen 3:15. Outside of Epid 11-16, this is the most developed and coherent reading of Gen 1-3 in all of Irenaeus' extant work.

Third, a common means of coordinating passages is vocabulary or catchwords that make philological connections between texts. In many cases these are explanatory in nature and offer qualifications or definitions for the terms in Gen 1-3. In $A H 3.11 .5$, he links the miracle of the wedding feast at Cana with the creation of flora (Gen 1:11), including the grapevine, and water (Gen 1:9). A particularly common linking term is the substance of Adam's flesh or "formation" (plasma) and the related images that he connects with the substance of plasma, which is not surprising given his anti-Gnostic polemic. In AH 3.18.1, the language of "formation" (plasma) and "human being" (hominem) links Gen 2:7, John 1:14, and Eph 1:10. Similar imagery is located in $A H$ 3.18.7, but he adds the allusion to the "virgin soil" (terra rudis) in Gen 2:5, which corresponds to the virgin birth of Christ and their subsequent contrastive acts of disobedience and obedience (Rom 5:12, 19). In AH 3.19.3 we find similar descriptions that relate Adam's "formation" (plasma) with the lost "sheep" (ouem) of Luke 15:4, and the "earth" (terra) of Eph 4:9. Similarly, in $A H$ 3.21.10 he connects Adam's "formation" (plasma) that is drawn from the "untilled earth" (rudi terra) of Gen 2:5 with the Word of God who forms all things (John 1:3) and the Adam-Christ typology of Rom 5:12, 19. Then, in AH 3.22.1, Irenaeus describes 
the "meek" (mites) nature of the flesh that is fashioned from the "earth" (terra, Matt 5:5, Gen 2:7). The three concluding sections of the chiasm in AH 3.23.6-8, contain the imagery of "life" (vitae, Gen 2:9, Rom 6:10), "serpent” (serpentem, Gen 3:15, Psalm 90:13 LXX, Rev 12:9/20:2), "seed” (semen, Gen 3:15, Gal 3:16,19), and “to tread upon” (calcare, Gen 3:15, Luke 10:19). These provide intricate linguistic or verbal connections between Gen 3:15 and the person and work of Christ.

Fourth, there are also general conceptual, theological, or typological connections that are not necessarily identifiable with any particular philological relationship. In most cases these connections are crafted through his theological perspective, and often closely related to a particular aspect of the work of Christ. The relationship between these texts is theologically symbiotic in the sense that each passage supports, extends, or demarcates the interpretation of other texts. As we mentioned above, in AH 3.11.5 the connections between Gen 1-2 and John 2 are ordered by a perspective that links that identity and work of the Creator with the identity and activity of Christ. A general Adam-Christ typology in AH 3.18.1 binds together Gen 2:7 and John 1:14, and these theological connections are supported by Deut 32:4 and Eph 1:10. The same theological perspective harmonizes Gen 2:5 with Rom 5:12,19, where Irenaeus' typological connections extend the logic of Paul's Adam-Christ typology. The "descending” (descendere) and "ascending” (ascendere) imagery in $A H$ 3.19.3 binds the Incarnation and the ascension though linking Isa 7:11, Luke 15:4-6, and Eph 4:9-10. The object of salvation in each case is man formed from the dust of the earth (Gen 2:7). In AH 3.20.1, Irenaeus follows an Adam-Jonah typology and reads the account of Jonah in light of the events of the Garden alongside Matt 12:39-40 and 1 Cor 1:29. The "sign of Jonah" in Matt 12:39-40 is the controlling text, which serves to coordinate Jonah 1:9, Jonah 2:1-2, and Jonah 3:1, 89, with an allusion to the disobedience of Adam and Eve in Gen 3:5-8. In this reading, the "great whale" (magna ceto) is Satan, who deceives the first couple in the Garden, but Adam, like Jonah, received an unexpected salvation from the captivity of this "whale." In yet another typological relationship, Irenaeus reads the actions of Eve in correspondence to those of Mary in AH 3.22.1. Whereas Eve becomes the cause of death in Gen 3:6, Mary is the cause of salvation and resurrection in Luke 1:38, Heb 5:9, and Eph 4:16/Col 2:19. Finally, the chiasm of AH 3.23.1-8 and the closing sections abound with conceptual and theological connections. There is a general connection 
between creation in the image of God and salvation in AH 3.23.2, where the work of Christ has overcome the hostile force that took captive humanity that was created in the image of God. The condemnation of this evil one is confirmed in the links between the curse of Gen 3:14 and the eternal fire described in Matt 25:41. The Adam-Cain typology in AH 3.23.4-5 also continues the various typological relationships mentioned previously. While Cain was insolent before God, Adam was contrite; and his contrition is aptly described as the proper fear of God in Prov 1:7. Fifth, Irenaeus conflates texts with a type of prosopological (prosopographic) interpretation where he identifies individuals in Gen 1-3 with other persons mentioned elsewhere in scripture. In AH 3.21.10, the Word of God creating all things in John 1:3 is the same person creating Adam in Gen 2:7. In the closing section of $A H 3.24 .2$, he provides a more developed perspective on the activity of God in creation by reading the Word of Psalm 32:6 LXX and the Wisdom of Prov 8:30 in continuity with Gen 1:26, Gen 1:28, and Gen 2:7.

Sixth, Irenaeus also demonstrates an illustrative application of texts, where he uses passages to exemplify a theological argument. In AH 3.23.8 he portrays the Gnostics as contemporary manifestations of the serpent, who are, like the serpent, attempting to deceive the people of God and lead them into disobedience. Then, in AH 3.24.1 he compares the breath of God that is imparted to Adam in Gen 2:7 with the church as the vessel of Matt 12:29 that has received the precious deposit of the Spirit.

From beginning to end all of these intertextual strategies guide his intertextual reading of Gen 1-3 as he crafts his theological polemic against the Gnostics. The complexities of his intertextual reading of Gen 1-3 only continue to develop in AH 4-5 as he advances his Christological and anthropological considerations. 


\section{CHAPTER 5: THE INTERTEXTUAL RECEPTION OF GENESIS 1-3 IN BOOK 4 OF ADVERSUS HAERESES}

\subsection{Introduction}

Having evaluated the meaning and function of Gen 1-3 in the first three books we see that the intertextual performance of these passages in Irenaeus' own thought is beginning to take shape. At every turn we discover that Irenaeus is not so concerned with the isolated and individual meaning of any singular Genesis text, but the theological interaction of texts. For Irenaeus, the meaning of Gen 1-3 is bound up in the correspondence of texts. As a result, the intertextual performance of Gen 1-3 continues to flourish in AH 4. We have already noted, following Bacq's groundbreaking study on this book, AH 4 is organized around scripture. ${ }^{1}$ Bacq argues convincingly that the "words of the Lord" give unity and coherence to $A H 4$ that was heretofore unrecognized.

The purpose of $A H 4$, following the Christological arguments of $A H 3$, is to prove the existence of one God who is active throughout all salvation history. According to Bacq's structure, the content of $A H 4$ may be framed in four larger sections. Following a short introduction, $A H$ 4.1-19 argues there is one God who is both Creator and Administrator throughout both Testaments as evidenced in the words of the Lord. AH 4.20-35 anticipates the prophecy of the Old Testament in the New and some writers in the post-apostolic age. Finally, in AH 4.36-41 he concentrates on the proof of one God who is active throughout salvation history, as evidenced in the parables of Christ. The closing section, AH 4.41.4, provides a short conclusion summarizing the unity of God in the Lord's words and previews the argument for the resurrection of the body in $A H 5$.

Within this purpose and structure, several chapters boast meaningful intertextual uses of Gen 1-3. ${ }^{2}$ The methods of intertextual networking in this

\footnotetext{
${ }^{1}$ Bacq, De l'ancienne. While he does not achieve the magnitude of his work on $A H$ 5, Antonio Orbe's translation and commentary on $\mathrm{AH} 4$ is a pivotal for understanding the nature of this book. Orbe, Teología IV.

${ }^{2}$ AH 4.pf.4, 4.6.2, 4.10.1, 4.11.1-2, 4.14.1, 4.16.1 4.20.1-4, 4.32.1, 4.33.4, 4.34.4, 4.36.2-6, 4.37.4, 4.38.1-4, 4.39.2, and 4.40.3. BP also lists other possible echoes including: Gen 3:1-6 in AH 4.2.7 and AH 4.24.1 (cf. Num 21:4-9), Gen 1:27 in $A H$ 4.15.2 (cf. Matt 19:7-8), Gen 2:7 in $A H$ 4.31.2 and $A H$ 4.41.4, Gen 3:8 in $A H$ 4.11.1, and Gen 1:26 in AH 4.37.7 (cf. Rom 8:29). In each of these instances there is no clear echo of Gen 1-3 and in most cases Irenaeus has another passage in mind (even if these text are not always distinguishable from his use of Gen 1-3).
} 
chapter also display the full spectrum of Irenaeus' uses of Gen 1-3 including: narratival connections, catchwords, a "plain sense" reading, theological or typological connections, prosopological interpretations, illustrative application of texts, general-to-particular argumentation, and specific canonical arrangements of texts that coordinate a prophetic text, a Gospel text, and an apostolic text. These intertextual connections formed with Gen 1-3 continue to reveal the pivotal nature of Gen 1-3 in the thought of the Bishop of Lyon.

\subsection{AH 4.pf.3-4: The Heretics and Gen 1-3 (Gen 1:26, Gen 2:7, Gen 3:1-5)}

The preface to $A H 4$ reminds the reader of Irenaeus' overall purpose: the detection and refutation of Gnosis by way of exposing the fallacies of their doctrinal systems. What concerns Irenaeus most is the representation of the Creator as defective and ignorant. In contrast to the heretics, Irenaeus appeals to the authority of the apostleswhom Irenaeus reminds us were "eye-witnesses" (speculators, Luke 1:2) of the Lord's work. These same apostlesnot only witnessed the Christ event, but petition their disciples to reject the contentious opinions of the heretics because the "weakminded" (simpliciores, 2 Tim 2:23) may be led astray. ${ }^{3}$ In the spirit of the apostles, Irenaeus envisions his own work as protecting the simple from the exploitation of the heretics. He goes so far as to cast the deceptive teaching of his opponents as manifestations of the seductions of the serpent in Gen 3:1-5. ${ }^{4}$ For Irenaeus, those who claim to have "superior knowledge and ineffable mysteries" (majorem agnitionem et mysteria inenarrabilia, 2 Cor 11:3) carry out the same deception as the serpent. ${ }^{5}$ Like Eve, in the Garden, those who are deceived by the heretics become apostate from the church and subject to death. ${ }^{6}$ In this way, Irenaeus identifies the Gnostics as those who Paul condemns in 2 Cor 11:3, and those who offend the apostolic teaching mentioned in Luke 1:2. He does so, accoding to Irenaeus, to protect the "weak-minded" (2 Tim 2:23, simpliciores) in the faith.

Irenaeus recognizes that for all their differences the various Gnostic sects are unified in the general rejection of the Creator God in Genesis, which Irenaeus

\footnotetext{
${ }^{3} \mathrm{AH}$ 4.pf.3. Irenaeus identifies himself as one of these disciples with the first-person plural pronoun "us" (nobis). This means that, in a certain sense, Irenaeus views his refutation against the Gnostics as following the commission of the apostlesthemselves.

${ }^{4} c f$. AH 3.23.8.

${ }^{5}$ AH 4.pf.4

${ }^{6}$ AH 4.pf.4
} 
believes inherently disparages salvation. Echoing the imagery of Gen 2:7, he describes the composition of humanity as a "mixed organization of soul and flesh" (temperatio animae et carnis). ${ }^{7}$ The union of the soul and the flesh is reflective of the fashioning of the body and the impartation of the breath/soul derived from Gen 2:7, where God, taking dust from the earth moulds the man and breathes into him the breath of life. He conflates Gen 1:26 with his description of a bipartite formation where humankind "was formed after the likeness of God, and moulded by His hands, that is, by the Son and Holy Spirit, to whom also He said, 'Let Us make man"” (secundum similitudinem Dei formatus est et per manus ejus plasmatus est, hoc est per Filium et Spiritum, quibus et dixit: Faciamus hominem). ${ }^{8}$ The emphasis on the firstperson plural subjunctive verb, "Let Us make" (Faciamus), is found here and in AH 4.20.1 and most naturally applies to the activity of the Son and the Spirit.'

The Valentinians and other Gnostics applied the plural pronoun to a variety of angelic beings and powers. Irenaeus mentioned the function of angels in his summaries of Valentinus, Menander, Saturninus, Basilides, and Carpocrates. ${ }^{10}$ Those who have departed from the notion of God as Creator have rejected the "salvation of God's workmanship, which is the flesh." ${ }^{11}$ Salvation, as Irenaeus will make explicit a few lines later, is the restoration of the whole person that is soul and flesh. He has one creation event in mind and each passage contributes something to the formation of humanity. Gen 2:7 describes the constitution of the human person, including body and soul, while Gen 1:26 describes how this human person is made in the image and likeness of God. The rejection of the salvation of the whole person is the link between 2 Cor 11:3 and the activity of Satan in the Garden and the promulgation of the Gnostic teaching. As the serpent deceived Adam and Eve and led them to death, so now the Gnostics are deceiving the faithful and turning them away from the church.

\footnotetext{
${ }^{7}$ AH 4.pf.4

${ }^{8}$ AH 4.pf.4

${ }^{9}$ Steenberg, Irenaeus, 74. The same manner of interpretation is found in Epid 55, 4.20.1, 5.1.3, 5.15.4

${ }^{10}$ See $A H$ 1.23.5; AH 1.24.1-4; $A H$ 1.25.1.

${ }^{11}$ AH 4.pf.4.
} 


\subsection{AH 4.6.2: The Son and the Father (Gen 1:26, Gen 1:28, Gen 2:7)}

This chapter is crucial for determining Irenaeus' dependence upon Justin. Focusing upon this section, Michael Slusser recently summarized the various positions and argued persuasively that Irenaeus learned "all that Justin had to teach him."12 This is, after all, the only instance where Irenaeus cites a portion of Justin's lost work against Marcion. The citation of Justin in AH 4.6.2 acts as an inclusio to Irenaeus' general anti-Gnostic polemic against the Valentinian reading of Matt 11:27. ${ }^{13}$ The whole of $A H$ 4.6.1-7 concerns the interpretation of this Gospel logion and the revelatory nature of the Father-Son relationship in the Incarnation. Orbe has an extensive treatment of this chapter evaluating the competing Irenaean and Valentinian readings of Matt 11:27 (along with Origen). ${ }^{14}$ The Valentinians convert

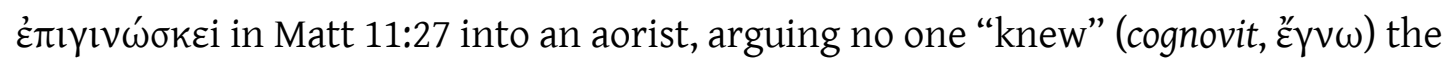
Father except the Son, so the Father announced by the prophets is not the same Father of Christ revealed in the Son. ${ }^{15}$ Prior to the New Covenant, this Father was unknown. Although, as Orbe observes, it is not altogether clear if Irenaeus rejects the variant reading in particular or the Valentinian application of the verb, most likely the latter, but either way Irenaeus' exegesis exploits the present tense

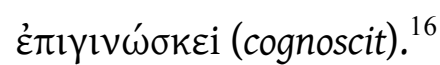

The citation of Justin in AH 4.6.2 begins with an echo of Christ's words in John 5:31, but Justin reinterprets the language to say, "I [Justin] would not have believed even the Lord Himself, if He had announced any other than He who is our framer, maker and nourisher" (Ipsi quoque Domino non credidissem alterum Deum annuntianti praeter Fabricatorem et Factorem et Nutritorem). ${ }^{17}$ For Justin (and Irenaeus), contra Marcion, the relationship between the Father and the Creator and the Son is

\footnotetext{
${ }^{12}$ Slusser, "How Much," 520. One of the more significant disagreements is the length of his citation of Justin. The last clause refers to Christ's work of recapitulation, which, if original, may suggest that Irenaeus derived his doctrine of recapitulation from Justin. Among other arguments, scholars who opt for the shorter reading point to the parallel citation in Eusebius who omits the final clause. Slusser, "How Much." 518; Eusebius H.E. 4.18.9; See also Steenberg, Irenaeus, 17-18; Grant, Irenaeus, 39. ${ }^{13}$ Slusser, "How Much," 519. Eusebius mentions this work, as well as Photius. See EH 4.18.9.

${ }^{14}$ Orbe, "La Revelacion Del Hijo Por el Padre Segun San Ireneo (Adv. Haer. IV,6): Para la exegesis precivena de Matt 11,27," in Teología De San Ireneo IV: Traducción y Comentario del Libro IV del «Adversus haereses» (Madrid: Biblioteca de Autores Cristianos, 1996): 50-103, originally published in Greg 51 (1970): 5-83.

${ }^{15}$ AH 4.6.1. Orbe, "La Revelacion," 53, 100; Slusser, "How Much," 519; cf. AH 1.20.3.

${ }^{16}$ Orbe, "La Revelacion," 52-53; AH 4.6.1,3; Slusser, "How Much," 519-20.

${ }^{17} \mathrm{AH}$ 4.6.2. Similar argument and imagery is found in $A H$ 4.6.6 and $A H$ 4.7.4.
} 
so essential that Justin would not believe the incarnate Son if he denied his relationship to the Creator. ${ }^{18}$ Only the Creator, who is revealed in Christ, is able to form, nourish, and bring humanity to their appointed consummation. ${ }^{19}$ The three titles "Framer" (Fabricatorem), "Maker" (Factorem) and "Nourisher" (Nutritorem) are echoes of the creation of humanity in Gen 1-2. Although the verbs are not exactly parallel, the three-fold allusion must mirror the three creation texts: Gen 1:26, Gen 2:7, and Gen 1:28. Irenaeus uses a variety of verbal cognates to describe the creation and preservation of Adam. ${ }^{20}$ These are not incremental or progressive in relationship-that is the interpretation of the heretics-but the three-fold use of the verbal titles indicates his harmonious reading of Gen 1-2, where all the titles refer to the same divine being. ${ }^{21}$ The harmonious reading of creation texts in Gen 1-2 is also buttressed with echoes of Gen 1-2 that refer to the Son of God who "made this world" (mundum fecit), "formed" (plasmavit) humanity and "administers" (administrat) all things. The administration over creation anticipates the Incarnation, where he "recapitulates his own handiwork in himself" (suum plasma in semetipsum recapitulans, Eph 1:10). ${ }^{22}$ The language of plasma is a common reference to the substance of Adam's formation in Gen 2:7. ${ }^{23}$ For Justin and Irenaeus the echoes of the creation of the world, creation of humankind, and the administration of "all things" fashion links between creation and the Incarnation that support the connections between the Creator and the Father of Christ. This reference to Justin also links Irenaeus' reading of Matt 11:27 to the Son's creative activity in Gen 1-2.

\subsection{AH 4.10.1: The Son Inquiring after Adam (Gen 3:9)}

As we found in the previous section, the typological and prophetic connections between the Testaments are central to the Irenaean-Gnostic disputes. The general argument surfaces in $A H 4.10 .1$ where he attempts to validate Old Testament

\footnotetext{
${ }^{18} \mathrm{EH}$ 4.18.9. Eusebius notes that Irenaeus cites Justin, but his citation only mentions the language of "Creator" rather than of the three titles.

${ }^{19}$ Orbe, "La Revelacion," 58.

${ }^{20}$ He typically cites faciamus in Gen 1:26 (AH 4.20.1, AH 5.1.3), plasmavit in Gen 2:7 (AH 4.11.1, AH 4.20.1) and crescite et multiplicamini in Gen 1:28 (AH 4.11.1). However, Irenaeus' style and argument frequently employs cognates and parallels. For example, in AH 4.11.1 he states that God "formed" (plasmavit) Adam for "growth and increase" (augmentum et incrementum) and he also uses factus AH 3.23.3 to refer to Gen 1:26.

${ }^{21}$ See also $A H$ 2.28.1; AH 3.24.2; AH 4.38.3; and the discussion of scriptural titles in AH 3.7.2.

${ }^{22}$ AH 4.6.2.

${ }^{23}$ Behr, Asceticism, 38.
} 
Christological prophecy with allusions to John 5:39-40 and John 5:46. Drawing upon Christ's own assertion that Moses spoke of him in John 5:39-40, Irenaeus suggests that the "Son of God is implanted everywhere throughout his Scriptures" (inseminatus est ubique in Scripturis ejus Filius Dei). ${ }^{24}$ As general evidence he lists a series of Christophanies in the Mosaic writings, including the Son of God conversing with Adam in Gen 3, Abraham in Gen 18, Noah in Gen 6, and Moses in Exod 3. These appearances are merely exemplary because he concludes there are countless instances where Moses reveals the Son. ${ }^{25}$ His reference to the Son's "inquiring after Adam" (autem quaerens Adam) in Gen 3:9 reflects the moment when Adam and Eve hid from God following their disobedience in Gen 3:6. In this context he offers little commentary because his point is not to explain why the Son conversed with Adam, but to show this passage participates in a number of theophanic accounts where the Son of God is found interacting with creation. Gen 3:9 is the first of many Christophanies and prophecies hidden in the Mosaic writings and illustrating where Moses spoke of Christ (John 5:39-40; John 5:46).

\subsection{AH 4.11.1-2: The Prophets and Salvation History (Gen 1:28)}

In Irenaeus' thought the purpose of creation is never separated from the economic nature of salvation history. The opening lines of AH 4.11.2 summarize this view with a well-known Irenaean axiom: "God makes, but the human being is made" (Deus quidem facit, homo autem fit). ${ }^{26}$ The present tense of facit and fit, suggest creation is not a singular event but an ongoing process whereby God perpetually forms the human person and prepares them for ressurection. Behr describes this view as the "unalterable fact of creation." "27 God is always the same, but humanity must receive a "beginning, middle, and addition with increase" (initium et medietatem et adjectionem et augmentum) ${ }^{28}$ For Irenaeus, God is completely self-sufficient, while the creature has unremitting need. ${ }^{29}$ This need is epitomized in the salvation and

\footnotetext{
${ }^{24}$ AH 4.10.1; Orbe, Teología IV, 135.

${ }^{25}$ AH 4.10.1; cf. Epid 43-46.

${ }^{26}$ AH 4.11.2.

${ }^{27}$ Behr, Asceticism, 37

${ }^{28}$ AH 4.11.2; Steenberg identifies a parallel passage in Philo, who also cites Plato. Steenberg, Irenaeus, 35.

${ }^{29}$ D. Jeffrey Bingham, “Christianizing Divine Aseity: Irenaeus reads John” in The Gospel of John in Christian Theology, eds. Richard Bauckam and Carl Mosser (Grand Rapids: Eerdmans, 2008): 53-67, 55.
} 
perfection of humanity achieved through the organized trajectory of salvation history and this trajectory is nowhere more evident than the creation mandate of Gen 1:28: "Increase and multiply" (Crescite et multiplicamini). Irenaeus' reading of Gen 1:28 creates a salvific paradigm for the growth and advancement of humankind toward God. The divine activities of the Word in the Old Testament detail the means of this "growth and increase" (augmentum et incrementum) which also reflects the progressive nature of human salvation. ${ }^{30}$ He explains this clearly in connection to Gen 1:28 saying, "For He formed him for growth and increase, as the Scripture says: Increase and multiply" (Plasmavit enim eum in augmentum et incrementum, quemadmodum Scriptura dicit: Crescite et multiplicamini). ${ }^{31}$ Steenberg undervalues the broader influence of this passage, only mentioning the citation of Gen 1:28 in this context and a second allusion in $A H 3.22 .4 .^{32}$ The latter allusion he sets aside as "incidental." ${ }^{33}$ But his evaluation of Gen 1:28 is correct when he describes how Irenaeus uses Gen 1:28 “to establish the necessity for the course of humanity's growth via the implication of a temporal ascendancy in the command." 34 This is an advancement from Behr, who, despite framing an entire chapter on "human growth" in Irenaeus' anthropology, rarely attributes this growth to Irenaeus' reading of Gen 1:28. ${ }^{35}$ Furthermore, Steenberg rightly emphasizes the human aspect, but neglects the Trinitarian activity initiated by this command. Orbe points us to the two-fold implication of Gen 1:28: the Word of God continually forms the human person and the human person continually maintains obedience in faith. ${ }^{36}$ The Son, obeying the Fathers' command, actively enables the human advancement in salvation. What is more, throughout salvation history the messianic expectation of the OT prophets is evident. Citing Matt 13:17, Irenaeus reasons that the prophets, throughout every episode of salvation history, desired to see the advent of the Son. He specifically mentions the activity of the Word of God conversing with his

\footnotetext{
Steenberg distinguishes between spatial, temporal, and cooperative self-sufficiency. Steenberg, Irenaeus, 73.

${ }^{30}$ Behr does not develop Irenaeus' concept of "human growth" with respect to Irenaeus' reading of Gen 1:28. Behr, Anthropology, 38. See also AH 3.22.4, AH 4.38.3.

${ }^{31}$ AH 4.11.1.

${ }^{32}$ Irenaeus alludes to Gen 1:28 in several other contexts: Epid 11, AH 1.28.1, AH 2.28.1, AH 3.24.2, AH

4.38.3, and $A H$ 5.33.3-4.

${ }^{33}$ Steenberg, Irenaeus, 97

${ }^{34}$ Steenberg, Irenaeus, 96; cf. Bacq, De l'ancienne, 96 n. 2. Behr Asceticism, 37 n. 12.

${ }^{35}$ Behr, Asceticism, 116-27. He mentions Gen 1:28 several times, but does not develop Irenaeus reading of this text. Behr, Asceticism, 37-38 n. 12, 112.

${ }^{36}$ Orbe, Teología IV, 143.
} 
creatures and dictating the law, along with the general description of the times where God reproved and exhorted his people. All of these actions are organized in such a manner to bring Adam to a state of perfection, because Adam is by nature formed for growth and increase. This distinction, therefore, demonstrates the personal and progressive nature of Irenaeus' reading of Gen 1:28 that directs the faithful toward sanctification and glorification.

In AH 4.11.2 Irenaeus uses the notions of "growth and increase" (augmentum et incrementum) found in Gen 1:28 to contrast divine aseity with human necessity. The Bishop of Lyon argues that God is perfect, but humankind receives “advancement and increase towards God" (percipiens et augmentum ad Deum). ${ }^{37}$ In other words, God creates, while humanity is created. God gives, while humanity receives. ${ }^{38}$ Nevertheless, the human person must allow God to work out his or her salvation. ${ }^{39}$ Those who are grateful toward God become receptors of God's goodness. They are the "good and faithful servant" (serve bone et fidelis) of Matt 25:21 who are continually given an increasing amount of administration and continuously bearing fruit unto eternal life. But those who reject the creative activity of God become the receptors of his judgment. ${ }^{40}$ In the reading of Irenaeus, Matt 25:21 is a confirmation and quality of growth and increase in Gen 1:28 that incrementally and continually prepares the faithful to receive God. ${ }^{41}$

\subsection{AH 4.14.1: Why God Created Humankind (Gen 2:7)}

The question of God's primordial activity is not a subject Irenaeus considers with any regularity. But in reaction to the extensive primordial speculations of the heretics, AH 4.14.1 is one of a few instances where he contemplates God's motivation for creation. ${ }^{42}$ For Irenaeus, God's creative impulse is the ultimate glorification of humanity as an outworking of the mutual glorification of the Father and the Son.

\footnotetext{
${ }^{37}$ AH 4.11.2.

${ }^{38}$ Orbe, Teología IV, 146.

${ }^{39}$ Behr, Asceticism, 40.

${ }^{40}$ AH 4.11.2.

${ }^{41}$ Behr has read this passage in light of $A H$ 3.22.4 to communicate the developing sexuality in the prelapsarian Adamic state, which has some merit, but Steenberg is right to point to the Christological focus of this passage. Steenberg, Irenaeus, 97; Behr, "Irenaeus AH 3.23.5, and the Ascetic ideal," StVTQ 36.4 (1993), 309-10.

${ }^{42}$ Orbe, Teología IV, 189. According to Rousseau AH 4.14.1 is really a continuation of the argumentation in $A H$ 4.13.4. He frames $A H$ 4.13.4 into two sections. The first section includes SC 100:534.79-536.103, while the latter section spans SC 100:536.104-546.65 and includes AH 4.14.1-2.
} 
Irenaeus initiates AH 4.14.1 explaining how God did not form Adam out of necessity, echoing Gen 2:7, but so that God might confer the blessing of glorification upon him. ${ }^{43}$ He turns to the sacerdotal prayer in John 17 and, citing John 17:5, reflects upon the common glorification of the Father and Son before all creation that is poured out incrementally upon the formation of Adam. Irenaeus' vision of God's aseity imagines the eternal perfection of the inter-Trinitarian relationship that eliminates any dependence whatsoever upon creation; the Creator "stands in need of nothing and no one." ${ }^{44}$ Furthermore, God did not require the service of humanity, but called them out to follow after God so that they might participate in salvation. For Irenaeus, the glory of humankind is to remain permanently in God's service. ${ }^{45}$ For this reason he argued in the previous section that God did not befriend Abraham out of necessity, but so that Abraham might experience the "Trinitarian life of glory." 46 This unilateral relationship characterizes the interaction between God and humanity from creation. ${ }^{47}$ As Steenberg writes, "As much as it is inherent in man's nature to be made, so it is inherent in the nature of God to make, to create, and to fashion." 48 of course, in the myth of his opponents perfection is reserved for the unknown Father; the Gnostic Demiurge is delinquent and defective. ${ }^{49}$

Irenaeus supports the nature of this unilateral relationship between God and creation with a collection of texts including: John 15:16, John 17:24, Isa 43:5-7, and Matt 24:28. ${ }^{50}$ They are linked through parallel language and concepts of preexistence, creation, and glorification. The intention of God from creation is the glorification of the human person through divine fellowship and service of God. This God, contra the Marcionites and Valentinians, is the Creator of Adam in Genesis and the Father of Jesus. ${ }^{51}$ In the manner of an "architect" (architectus), God

\footnotetext{
${ }^{43}$ AH 4.14.1.

${ }^{44}$ Bingham, "Christianizing Divine Aseity," 55.

${ }^{45}$ AH 4.14.1.

${ }^{46}$ Behr, Anthropology, 36.

${ }^{47}$ This section is essential to Behr's portrayal of Irenaeus' understanding of the divine economy. Behr, Asceticism, 36-37.

${ }^{48}$ Steenberg, Irenaeus, 35.

${ }^{49}$ Bingham, "Christianizing Divine Aseity," 58.

${ }^{50}$ The key passage for Christ's preexistence is John 8:58 cited in AH 4.13.4

${ }^{51}$ Orbe, Teología IV, 189.
} 
sketches out the "construction of salvation" (fabricationem salutis) that unifies the trajectory of salvation history recorded in scripture. ${ }^{52}$

Therefore, just as the Word formed Adam in Gen 2:7 so that he might confer blessing upon him, so also, citing the dominical saying of John 15:16, the Bishop of Lyon says Christ chooses the disciples to follow him. Likewise, Christ does not need his disciples but his disciples are glorified when in fellowship with the Son. The disciples did not choose to follow Christ any more than Adam chose to be created. He then adds an allusion to John 17:24, explaining how the disciples, beholding the glory of Christ, participate in his glory. Isa 43:5-7 also follows the same logic and explicitly mentions the divine intention of glorification for the one whom God formed ${ }^{53}$ Finally, Matt 24:28 completes this collection of passages supporting Irenaeus' vision of unilateral nature of the divine-human relationship from creation. The text is part of Christ's apocalyptic warnings that characterize the dreaded "Day of the Lord" with a "proverb-like" saying: "Wherever the corpse is, there the eagles will gather" (ubicumque est cadaver, illuc congregabuntur et aquilae). ${ }^{54}$ He interprets the eagles gathered around the carcass as the resurrected faithful gathered around the glorified body of the Son of God and participating in his glory. ${ }^{55}$ Together these passages theological illustrate the mutual glorification of the Father and the Son that is motivating the formation of Adam in Gen 2:7. God's aseity that initiates creation instructs humankind through a unilateral divinehuman relationship that characterizes all interactions throughout salvation history so that the blessing of glorification innate to the Father and the Son is bestowed upon Adam and his posterity.

\subsection{AH 4.16.1: The Sign of Sabbath Rest (Gen 2:2-3)}

In AH 4.16.1 Irenaeus argues that God created circumcision and Sabbath as signs of identification for the children of Abraham. He states that these signs are not without purpose because they "prefigured" (praefigurabat) the coming of the Spirit

\footnotetext{
${ }^{52}$ AH 4.14.2; Behr, Asceticism, 53. Bacq suggests this is an allusion to the construction of the Ark in Gen 6:13-16; Bacq, De l'ancienne, 117.

${ }^{53}$ AH 4.14.1.

${ }^{54}$ Ulrich Luz, Matthew 21-28: A Commentary, trans. James E. Crouch (Minneapolis: Augsburg Fortress, 2005), 199.

${ }^{55}$ Luz notes this allegorical reading is common from Hippolytus onwards. Luz, Matthew 21-28, $200 \mathrm{n}$. 158. Orbe, Teología IV, 188 n. 12.
} 
and the eschatological Sabbath (Gen 2:2-3). Following his discussion of circumcision as a sign, his reference to the Sabbath begins with an allusion to Exod 20:12, Exod 31:13 and Rom 8:36. ${ }^{56}$ Both Exod 20:12 and Exod 31:13 describe the Sabbath as a "sign" (signo) between God and his people, which symbolizes the expectation for the people of God to live perpetually in God's service. Orbe determines two senses of the Sabbath rest: 1) immediate rest from work, and 2) the continual service of God involving the perpetual sacerdotal exercises and service at the table of God. ${ }^{57}$ While Orbe only explicitly applies Gen 2:2-3 to the former sense, through his practice of linking scriptures, the latter sense is expressed though a series of theologically interlocking passages. He characterizes this continual divine service with the imagery of preparing "sheep for the slaughter" (oves occisionis) in Rom 8:36. ${ }^{58}$ The people of God are like the sheep prepared for the sacrifice, which he understands as the people ministering continually and persevering in the faith. They abstain from all greed and, drawing upon the language of Matt 6:19, do not store up for themselves treasures on earth. This imagery of the "earth" (terra) inspires a reference to the Sabbath rest instituted at the conclusion of creation in Gen 2:2-3. Here the Sabbath rest in Gen 2:2-3 is a "sign" (signa) that points toward the eschatological Sabbath when humankind will perpetually dwell in the kingdom of God. Connecting Rom 8:36 and Gen 2:2-3, Irenaeus suggests the person who preservers in the service of the Lord will experience the peace of the Sabbath rest in the eschatological kingdom of God and dine at the table of the Lord. ${ }^{59}$

\subsection{AH 4.20.1-4a: Supremacy over All Things (Gen 1:26, Gen 2:7)}

This section presents another shift in Irenaeus' work with great attention given to old Testament prophecy. The focal point of this section may be characterized by the well-known Irenaean axiom: "the glory of God is a living person" (gloria enim Dei vivens homo) ${ }^{60}$ He believes the Son takes the creation into his divine life and, as a result, creation participates in the glory of God. ${ }^{61}$ The Valentinian emphasis on

\footnotetext{
${ }^{56}$ The discussion of circumcision links Gen 17:9-11, Deut 10:16, and Col 2:11.

${ }^{57}$ Orbe, Teología IV, 208.

${ }^{58}$ Noormann, Irenäus, 198.

${ }^{59}$ Orbe, Teología IV, 207 n. 10. Irenaeus will develop this argument in AH 5.33.2.

${ }^{60} \mathrm{AH} 4.20 .7$.

${ }^{61}$ Orbe, "Gloria Dei vivens homo: Análisis de Ireneo, adv. haer. IV, 20, 1-7," Greg 73.2 (1992): 205-68.

Behr, Asceticism, 262-63.
} 
ignorance is directly opposed to Irenaeus' identification of God's goodness or love as the primary motivation for creation. ${ }^{62}$ He cites Gen 1:26 and Gen 2:7 in AH 4.20.1, and these connect with a network of texts spanning AH 4.20.2-4a that argue for the creation of all things by means of the Word and Wisdom. ${ }^{63}$ The language of "all things" (omnia) links these passages, as well as a general-to-particular rhetorical argumentation. ${ }^{64}$ The end of this section is signified by summary statement that God has formed all things by his Word and Wisdom in AH 4.20.4a.

In AH 4.20.1 Irenaeus describes the greatness of God and its relationship to the notion of creatio ex nihilo and utilizes a general-to-particular mode of argumentation. This is not a God who forms from preexistent matter, but a God who creates out of nothing. ${ }^{65}$ God in Himself, Irenaeus argues, has "established, selected, adorned and contains all things, and among all things is us and this world" (constituit et fecit et adornavit et continet omnia, in omnibus autem et nos et hunc mundum). ${ }^{66}$ In this claim Irenaeus distinguishes himself from the Gnostic and Middle-Platonic doctrines of the origin of the world.$^{67}$ In this context he is not concerned with the Gnostics interpretation of Gen 1:26 but with their doctrine of God informing their reading. ${ }^{68}$ Irenaeus makes the general point that all things have been made by God and nothing exists that God has not created. At the same time, he wants to particularly emphasize humankind and the world as a subset within "all things" (omnia) that God has created. Gen 2:7 describes the particularity of the creation of humankind within "all things" (omnia) when reaching down "God formed the man, taking the dust of the earth, and breathed into his face the breath of life" (Et plasmavit Deum hominem, limum terrae accipiens, et insufflavit in faciem ejus flatum vitae). Irenaeus uses Gen 1:26, on the other hand, to depict the means by which God created, namely God created humankind within God. ${ }^{69}$ His argument, as

\footnotetext{
${ }^{62}$ AH 1.2.3; Steenberg, Irenaeus, 36-8; Mackenzie, Irenaeus's Demonstration, 95.

${ }^{63}$ Donovan, 116.

${ }^{64} \mathrm{cf}$. Shotwell, Biblical Exegesis, 32-33.

${ }^{65}$ AH 2.10.4; cf. Theophilus, Ad Autol 2.4.

${ }^{66}$ AH 4.20.1.

${ }^{67}$ Gerhard may, Creatio ex Nihilo: The Doctrine of 'Creation out of Nothing' in Early Christian Thought, trans. A. S. Worrall (Edinburgh: T\&T Clark, 1994), 168; Orbe, Teología IV, 276; cf. AH 4.38.3; AH 2.25.3; and AH 5.4.2.

${ }^{68}$ Steenberg, of God and Man, 25.

${ }^{69}$ If we break down Gen 2:7 into three sections: Gen 2:7a "God reached down taking dust from the earth and formed the man," Gen 2:7b: "and breathed into the man the breath of life," Gen 2:7c: "and the man became a living being." This is the only occasion where he provides a complete citation of Gen 2:7ab and at no point does Irenaeus cite Gen 2:7 in full.
} 
Orbe points out, inverts the Gnostic notions of the distinctive creative actions of the Demiurge. ${ }^{70}$ As Irenaeus argued in AH 4.14.1-2 and throughout AH 1, God stands in need of nothing to accomplish creation, because he possess his own Hands, that is the Son and the Spirit. This is God creating all things within God when the Father speaks to the Son and the Spirit saying, "Let Us make humankind after our image and likeness" (Faciamus hominem ad imaginem et similitudinem). ${ }^{71}$ There is, of course, much debate around the Trinitarian discussions of these pre-Nicene Fathers and anachronism is always a danger. But while some have argued Irenaeus is "terminologically-contradictory," the degree of overlapping Trintarian terminology is unmistakable. ${ }^{72}$ Mackenzie goes so far as to say, "There is little, if anything, in the Nicene formulae which is not present in embryonic or directional form in the works of Irenaeus." ${ }^{73}$ Conceptually speaking the act of creation necessarily includes the activity of all three persons, so that "He taking from Himself" (ipse a semetipso) formed all things by means of the Son and the Spirit communicates the creation of humanity is the corporate action united in will and purpose. The Father provided the substance of the clay, the Son acted as the paradigm for the formation of the man, and the Spirit enlivened the form. ${ }^{74}$ This presentation of the "mutual interrelatedness of the Trinitarian persons" is a striking example of the theological interpretation of Gen 1:26 and Gen 2:7. ${ }^{75}$ For this reason, the creation of human life, Irenaeus asserts, could not have been the work of angels, or powers, or any other creature, because they "are not able to create an image of God" (neque... poterant imaginem facere Dei, Gen 1:26). ${ }^{76}$

This theological reading is structurally connected to a cento of eight passages that are laced together through there connection to the notion of creatio ex nihilo and his reading of Gen 1:26 and Gen 2:7. ${ }^{77}$ The texts in AH 4.20.2 are arranged in the following order: Mand 1, Mal 2:10, Eph 4:6, Matt 11:27, Rev 3:7, John 1:3, 1 Pet 2:23, and Col 1:18, while the passages in AH 4.20.3 include: Prov 3:19-20, Prov 8:22-25,

\footnotetext{
${ }^{70}$ Orbe, Teología IV, 276.

${ }^{71}$ AH 4.20.1. Parallel uses are found in Epid. 55; AH 5.1.3; and AH 5.15.4.

${ }^{72}$ Steenberg, Irenaeus, 64.

${ }^{73}$ Mackenzie, Irenaeus' Demonstration, 29; Wingren, Man and the Incarnation, 105.

${ }^{74}$ Behr, Asceticism, 87; Orbe, Teología IV, 275 n. 9.

${ }^{75}$ Steenberg, Irenaeus, 114.

${ }^{76}$ AH 4.20.1; cf. AH 1.5.5; AH 1.18.6; AH 1.30.4-5.

${ }^{77}$ AH 4.20.2-3. For a discussion of creatio ex nihilio in Irenaeus: Orbe, "San Ireneo y la creation"; J. Fantino, La téologie, 265-337; Fantino, La crátion ex nihilo chez saint Irénée” RSPT 76.3, (1992), 421-42; Steenberg, Irenaeus, 38-49.
} 
and Prov 8:27-31. It is observable that Irenaeus makes the same general-toparticular argument as he did in the first section and the links between these texts is the language and concept of "all things" (omnia). The first four passages (Mand 1, Mal 2:10, Eph 4:6, and Matt 11:27) all contain the language of "all things" (omnia) and are related to the creation of all things generally to Gen 1:26 and the creation of humans in particular to Gen 2:7. He provides only brief commentary; in Irenaeus' thinking the connections between these texts are self-explanatory and explicit. These texts are themselves commentary on Gen 1:26 and Gen 2:7. Hermas describes how God, "established all things" (omnia constituit), while Mal 2:10 uses the same language asking the rhetorical questions, "Is there not one God who has established us? Have we not all one Father?" (Nonne unus Deus qui constituit nos? Nonne Pater unus est omnibus nostrum?). ${ }^{78}$ Eph 4:6 describes God the Father as "above all and in us all" (super omnes et in omnibus nobis), while Matt 11:27 records the Lord saying, "All things have been delivered to me by my Father" (Omnia... mihi tradita sunt a Patre meo). ${ }^{79}$ Although Irenaeus is not explicit about the timing of God's deliverance of all things to the Son (Matt 11:27), it seems right that, as Orbe suggests, this transpires at the Incarnation where the Son assumes the same substance of Adam's formation. ${ }^{80}$ In addition to the catchword omnia, Orbe carefully observes that this intertextual argumentation draws together an Old Testament reference (Mal 2:10), an apostle (Eph 4:6) and the words of the Lord (Matt 11:27). ${ }^{81}$ The canonical linkage is a means for Irenaeus to marshal the entire corpus of divine revelation in one continuous witness to the Father's creation of all things by means of the Word. In the remaining passages of Acts 10:42, Rev 3:7, John 1:14, 1 Pet 2:23, and Col $1: 18$, the emphasis is placed upon "all" human persons as a subset within all things. ${ }^{82}$ These latter five texts do not use the language or conceptual imagery of "all things" and, as a result, require commentary and connection. First of all, given

\footnotetext{
${ }^{78}$ O'Neill argues the citation of Hermes elevates it to "creedal status" of creation ex nihilo, but Steenberg rightly notes this overstates the case. J. C. O'Neill, "How early is the doctrine of creatio ex nihilo?" JTS 53.2 (2002), 455, 63; Steenberg, 'Scripture graphe, and the status of Hermas in Irenaeus,' SVTQ 53.1 (2008): 29-66.

${ }^{79}$ AH 4.20.2.

${ }^{80}$ Orbe, Teología IV, 278 n. 16.

${ }^{81}$ Orbe, Teología IV, 280.

${ }^{82}$ Holsinger-Friesen uses this section to describe the immediacy of God within the creation through Gen 1:26, but he neglects the main point that inclusiveness of God's creation is dependent upon Gen 1:26, while immediacy is dependent upon Gen 2:7. These readings are supported by a variety of intertexts. Holsinger-Friesen, Irenaeus, 118-119.
} 
all things have been given over to the Son, now the Son has the authority to judge the living and the dead (Acts 10:42). The inclusiveness of both the living and the dead comprises all persons, living and deceased. For this reason, alluding to Rev 3:7 and $\operatorname{Rev}$ 5:2, 3 and 9, only the Son has the authority to open the book of the Father because of his atoning sacrifice: a sacrifice, Irenaeus argues, that resulted in his receiving power over all things from the same God who "made all things by the Word and adorned them by his Wisdom (omnia Verbo facit et Sapientia adornavit). ${ }^{83}$ The Son alone has the power to judge all people, both the living and the dead. The preeminence of Christ over all things is also explained by the citation of John 1:14. The Son of God became flesh so that he might have "sovereignty in earth" (terra haberet principatum) as he has sovereignty in heaven. His sovereignty on earth, according to Irenaeus, is located in his righteous life depicted in 1 Pet 2:23. His authority over those things "under the earth," (sub terra) is also, according to Col 1:18, established in the fact that he is the first-born from the dead. The result of his preeminence is that "all things ... will behold their King" (et ut viderent omnia... suum Regem). This final allusion speaks of both the first and the second coming of the Lord where the incarnate Son returns to consummate the kingdom. Continuning his argument in $A H$ 4.20.1, God has created all things and in all things are both the living and the dead. In this way, Gen 1:26 and Gen 2:7 are key texts that must be supplemented theologically with an array of supporting texts, all communicating the theological notion that God created all things generally and humankind in particular.

Following this eight verse cento, Irenaeus cites Prov 3:19-20, Prov 8:22-25, and Prov 8:27-31 in AH 4.20.3, but he reserves his commentary on these texts for the opening lines of AH 4.20.4. These texts convey that God the Father existed with the Son and Spirit before all creation and refer back to the commentary on Gen 1:26 in AH 4.20.1. The two verbs fecit and aptavit, alongside the reference to Verbo and Sapientia, inspire the links between these texts. ${ }^{84}$ Prov 3:19-20 describes how "God by wisdom founded the earth" (Deus sapientia fundavit terram).$^{85}$ Likewise in Prov 8:22-25, it is Wisdom who is in the beginning with God before the creation of the

\footnotetext{
${ }^{83}$ AH 4.20.2.

${ }^{84}$ Orbe, Teología IV, 282.

${ }^{85}$ AH 4.20.3. Orbe suggests that Verbo et Sapientia in the opening line refers to Psalm 32:6 LXX, but the connections are too obscure to be certain. Orbe, Teología IV, $282 \mathrm{n} 24$.
} 
earth, while Prov 8:27-31 describes how Wisdom rejoiced with God at the completion of creation. ${ }^{86}$ The Wisdom of Prov 8:22 is the personal Spirit that is imparted through the Word of God. ${ }^{87}$ These texts fill out the theological reality of the primordial world where the Son and the Spirit are present with the Father prior to creation in Genesis, and support the reality that the Father created all things by His Word and Wisdom in Gen 1:26. Through the intertextual reading of Gen 1:26, Prov 3:19-20, Prov 8:22-25, and Prov 8:27-31, Irenaeus is able to say in AH 4.20.4, with the confidence of his scriptural harmony: "There is therefore one God, who by the Word and Wisdom created and arranged all things" (Unus igitur Deus, qui Verbo et Sapientia fecit et aptavit omnia). In other words, in Irenaeus' mind Gen 1:26, Prov 3:1920, Prov 8:22-25, and Prov 8:27-31 reflect the Father, Son and Spirit existing before the foundation of the world. Clearly Irenaeus is reading Gen 1:26 in correspondence with these texts expressing Christ's preexistence and activity from the opening pages of the scriptural narrative. The proclamation of Gen 1:26, "Let Us make" (Faciamus), expresses a divine reality that is already true and supported by an array of interrelated scriptures. Irenaeus closes with the summary statement that the Father is known though the Word, "through whom he established all thing" (per quem constituit omnia), which connects with the similar language in Mand 1 and Mal 2:10 in $A H 4.20 .2$ and the opening lines of $A H 4.20 .1$.

\subsection{AH 4.32.1: Word of God and the Unity of Scripture (Gen 1:3)}

This section is part of a long debated passage describing the teaching of an undisclosed certain "presbyter, a disciple of the apostles," who argues for the unity of the two Testaments under the activity of one God who is the Creator of all things. Charles Hill has argued convincingly that the presbyter is Polycarp. ${ }^{88}$ In this section, Irenaeus frames both his appeal to Genesis and the relationship of Gen 1-3 to the rest of salvation history as the teaching of this presbyter. ${ }^{89}$ To claim "angels" or

\footnotetext{
${ }^{86}$ AH 4.20.3.

${ }^{87}$ Orbe, Teología IV, 282.

${ }^{88}$ Charles E. Hill, From the Lost Teaching of Polycarp: Identifying Irenaeus' Apostolic Presbyter and the Author of Ad Diognetum. Hill, "Polycarp Contra Marcion Irenaeus' Presbyterial Source in AH 4.27-32," StuPat 40 (2006): 399-412.

${ }^{89}$ In keeping with his intertextual perspective, Irenaeus notes the result of departing from the unity of the Testaments results in "inconsistency" (incongruentiam) and "contradictions" (contradictiones). The only difference in this instance is that Irenaeus' is attributing this intertextual perspective to Polycarp.
} 
"another power" other than God created the world will not unite the teaching of the Old and the New Testaments. On the other hand, Irenaeus writes that those who believe one God made all things by the Word affirm the most basic theological assumption and the key that unlocks scriptural exegesis. This places the intertextual reception of Gen 1-3 and the apostolic teaching in the New Testament at the forefront of Irenaeus' objectives.

Irenaeus' exegesis of Gen 1:3 is distinctly "Trinitarian." He finds in the allusions to God "speaking" a clear delineation of the divine roles in creation. ${ }^{90}$ Steenberg is right to note that Irenaeus ignores the imagery of "light" (lux), which is so essential to Philonic and Gnostic readings of Gen 1:3, to concentrate solely on the "triune nature of God's creative activity." ${ }^{91}$ He begins with the claim that God created all things by the Word, alluding to John 1:3, and then cites Gen 1:3 saying, "God said, Let there be light: and there was light" (Et dixit Deus: Fiat lux, et facta est lux). ${ }^{92}$ The emphasis is placed on the verb "spoke" (dixit) as representative of the Son's involvement in creation with God the Father. Irenaeus cites Gen 1:3 specifically because it reflects the first act of speaking creation into existence, thereby communicating the notion that the Son is with the Father from the beginning of creation. He could have included any number of texts that contain God speaking creation into existence, such as Gen 1:6, Gen 1:9, and so on. ${ }^{93}$

These specific "verbal" links are supported by a range of Pauline and Johannine texts including: John 1:3, Eph 4:5-6, and Eph 4:15-16/Col 2:19. Together with Gen 1:3, all these texts communicate the unity of God in creation and the efficiency of his Word. ${ }^{94}$ We have already mentioned that Irenaeus alludes to the activity of the Word in creation in John 1:3, but he also adds a citation that even more clearly expresses the concept that all things were made in and through the Word. The use of Eph 4:5-6 expresses the singularity of God and the three-fold

\footnotetext{
${ }^{90}$ Steenberg, Irenaeus, 70. While Steenberg is right to say this is his only "quotation" of Gen 1:3, the parallel allusion to Gen 1:3 in AH 2.2.5 is unmistakable and supported by common textual referents. Steenberg, Irenaeus, 70.

${ }^{91}$ Steenberg, Irenaeus, 71 n. 24. Orbe makes attempts to interpret lux Christologically, but the context does not support this rendering.

${ }^{92} \mathrm{AH}$ 4.32.1. The emphasis on the consistency of the words (omnis sermo ei constabit) contributes to the notion of intertextuality in Irenaeus.

${ }^{93}$ It seems his use of Gen 1:3 is unusual, and one would expect Gen 1:26 in this context because he typically uses this text to speak of the divine proclamations. For this reason, I suspect in this case Irenaeus is actually reading or citing the teaching of the Presbyter.

${ }^{94}$ Orbe, Teología IV, 448 n. 6.
} 
expression that God the Father is above all, in all, and through all. ${ }^{95}$ Irenaeus uses this three-fold expression of Eph 4:5-6 as evidence of a triune God, who is over all creation. For Irenaeus, the blending of these three texts Gen 1:3, John 1:3, and Eph 4:5-6 teach that the Father created all things by means of His Son. The sources of these allusions also point to the unity between Moses, the Gospels, and the apostolic in their teaching that there is "one God who also made all things by the Word." This belief, for Irenaeus, is the "head" (caput) or foundation upon which all beliefs (or scriptures) rests.

He joins these three allusions with another echo of Paul's imagery of the body in Eph 4:16/Col 2:19, which he applies to his intertextual perspective of Genesis in an anti-heretical manner. ${ }^{96}$ The short introduction to this citation, "this one will first of all hold the head," (hic primo erit tenes caput) alludes back to the "one who believes in one God, who also made all things by the Word" (credat quis unum Deum et qui Verbo omnia fecit) mentioned a few lines earlier. ${ }^{97}$ When the interpreter of scripture grasps the "head" (caput) of the (scriptural) body (Eph 4:15-16/Col 2:19), which is the doctrine of the creation of all things by means of the Word of God expressed in Gen 1:3, John 1:3, and Eph 4:5-6, then this doctrinal "head" will guide the interpreter in the proper reading of scripture so that every part of the body of scripture will fit together in its appropriate arrangement. ${ }^{98}$ Irenaeus goes so far as to say that every word will be "in harmony" (consonare) for those who read the scriptures in contunity with the apostolic teaching that is found within the tradition of the church.

\subsection{AH 4.33.4: Ebionites and the Incarnation (Gen 1:26; Gen 2:7)}

On the heels of the previous section, in AH 4.33.1 Irenaeus appeals to 1 Cor 2:15 and then delineates the heretical groups who are subject to the judgment of the "spiritual disciple" (discipulus... spiritalis). In AH 4.33.4 he depicts the Ebionites and questions their perspective on the Incarnation. In doing so, he combines a number of allusions and echoes including: Gen 1:26, Gen 2:7, Isa 7:14, Matt 12:41-42, Matt 22:29, and Matt 22:43. He questions their understanding of salvation and how even

\footnotetext{
${ }^{95} \mathrm{cf}$. Epid 5, AH 2.2.5-6; and AH 5.17.4.

${ }^{96}$ Noormann, Irenäus, 243.

${ }^{97}$ AH 4.32.1.

${ }^{98}$ Orbe, Teología IV, 448 n. 7-8.
} 
they could escape the corruption of their bodies unless God had given them a "sign of salvation" (signum... salutis, Isa 7:14). ${ }^{99}$ With a set of rhetorical questions, he explains how Christ, who was of the same fleshy substance as David, Solomon, or Jonah, could be greater than them and powerful enough to subdue the one who is "stronger than men" (hominem fortis erat), echoing the role of Satan in Adam's disobedience (Gen 3:1-6). ${ }^{100}$ His closing question and final statement function rhetorically as responses to all these theological dilemmas. Alluding to the created of humankind in Gen 1:26, Irenaeus asks, "but who else is more superior and excellent than the man who was formed after the likeness of God, except the Son of God, after whose image man was created?" (Melior autem eo homine qui secundum similitudinem Dei factus est et praecellentior, quisnam sit alius nisi Filius Dei, ad cujus similitudinem factus est homo?, Gen 1:26). ${ }^{101}$ Christ must be greater than humankind because humankind was formed after his image and likeness. So also he is greater then David, Solomon, and Jonah (Matt 12:41-42, Matt 2:43), and the strong man, that is Satan, who subdued humanity (Matt 12:29, i.e. Gen 3:1-6). He was also God who was made human and received the birth from a virgin (Isa 7:14), thereby enacting the salvation from death. ${ }^{102}$ Irenaeus summarizes this conception of salvation in the closing lines with reference to the Incarnation and the conflation of John 1:14, Gen 1:26, and Gen 2:7 saying: "For this reason in these last days he has revealed the similitude; for the Son of God was made human, assuming the ancient formation into his own nature" (Et propter hoc in fine ipse ostendit similitudinem Filius Dei, homo factus, antiquam plasmationem in semetipsum suscipiens). The language of Son of God "became human" (homo factus) and "ancient formation" (antiquam plasmationem) calls to mind the imagery of the Word becoming flesh in John 1:14 and the formation from the dust in Gen 2:7. ${ }^{103}$ Salvation, therefore, is enacted in the recaptulatory nature of the Incarnation as reflected in similitude between Adam and Christ's formation.

\footnotetext{
${ }^{99}$ AH 4.33.4; cf. Orbe, "En torno a los Ebionitas," Aug 33 (1993): 315-37.

${ }^{100}$ Matt 12:29, Matt 12:41-42, and Matt 22:43.

${ }^{101}$ AH 4.33.4.

${ }^{102}$ AH 4.33.4.

${ }^{103}$ The echo of John 1:14 is not referenced in either BP or SC.
} 


\subsection{AH 4.34.4: Christ the Pruning hook (Gen 2:7, Gen 3:17-8)}

In AH 4.34-35 Irenaeus focuses his critique on Marcion, Valentinus, and their followers. He begins his criticism by challenging them to read scriptures and the writings of the apostlescarefully because the whole life of Christ is predicted in them. In $A H 4.34 .4$, it is the prophecy of the New Covenant that concerns Irenaeus. He addresses those who wish to take up the position of the Jews and interpret the New Covenant and the construction of the temple under Zerubbabel. ${ }^{104}$ Irenaeus argues that during this time no new covenant was given because they were still function under the Mosaic Law. ${ }^{105}$ But from the time of Christ the new covenant, which brings peace and life has gone out to the whole earth. This peace is not merely the peace between God and humanity, but also the peace between Jews and Gentiles. The new covenant, inaugurated through the life of the incarnate Son of God, becomes the "law of life" (vivificatrix lex), or "law of liberty" (libertatis lex), as he will later state, that fulfills the Law of Moses. ${ }^{106}$ He interprets the law of life or the "law of liberty" as the "word of God" (verbum Dei) preached by the apostles, who went out from Jerusalem into all the earth proclaiming the coming of this peaceful transformation. To this point, Irenaeus adds, that they used these instruments for peaceful purposes and, following Matt 5:39, when struck they did not retaliate but instead offered their other cheek. ${ }^{107}$ This transformation, however, is in toto applied to Christ. Irenaeus appeals to the language of John 4:37, "in him is the saying true" (hoc est sermo verus), to suggest that in Christ the proclamation of peace in Isa 2:3-4 is realized. $^{108}$

In his discussion of Isa 2:3-4, he finds the figuration of the Christ event in the imagery of the people of God transforming their swords into "ploughshares" (aratra) and their spears into "pruninghooks" (falces). ${ }^{109}$ Irenaeus remarks that the prophets spoke these words about no one other than the Son of God. He understands the same Son of God himself (ipse) as having introduced both the plough and the

\footnotetext{
${ }^{104} 1$ Esdr 3:7-13, 2 Chron 36:21, Dan 9:2-24, and Zach 1:2.

${ }^{105}$ Irenaeus appears to link the stone temple constructed by Zerubbel with the stone tablets of the Decalogue. This, for him, is the Law of Moses. cf. Orbe, Teología IV, 475 n. 35.

${ }^{106}$ Orbe, Teología IV, 475 n. 36.

${ }^{107}$ Matt 5:39.

${ }^{108}$ The text of John 4:37 is the conclusion to Jesus' discussion about the workers for the harvest in John 4:31-38. The context of reaping and sowing is a natural correlation to the farming imagery of ploughshares and pruning hooks.

${ }^{109}$ AH 4.33.4.
} 
pruning hook; he is both planting and harvesting. ${ }^{110}$ The distinction between the former and the latter is the mediation of these activities at distinctive economic stages through different human mediators. In the beginning, Adam and Abel prefigure the salvific activity of Son of God in Gen 2-4, while in the "last" days Christ-crucified and the apostolic preaching mediate the fulfillment of salvation.

First of all, in the earlier dispensation, the Son of God introduced the "plough" (aratrum) at the "formation of Adam" (Adam plasmatio) from the dust in Gen 2:7. He characterizes the act of formation in Gen 2:7 as the "first semination" (primam seminationem), drawing upon the Middle-Platonic imagery of planting and semination. ${ }^{111}$ The Son of God is, quite literally, tilling the ground and planting the first human form upon the earth. ${ }^{112}$ Orbe vividly describes this event saying: "El Verbo labró la tierra virgen, sembrando en ella, con Adán, el humano plasma; y lo recogió con Cristo, fructificado ya a Su imagen y semejanza." ${ }^{113}$ Although informed by an economic understanding, there is little doubt that the "earth" (terra) imagery in both texts informs this intertextual connection. In the New Convent, the "plough" (aratrum) is revealed in the crucifixion when "wood joined with iron" (lignum copulatum ferro) so that Christ's bodily sacrifice "cleansed his earth" (expurgavit ejus terram). This imagery points to Christ's crucified body nailed to the cross with iron spikes as the purification and atoning sacrifice. Through his bodily sacrifice on the cross, Christ, in a sence, "ploughs" the earth, thereby purifying the formation of Adam from the "earth" (terra) in Gen 2:7. Although Orbe implies a connection in the respective forms of the cross and the plough, this is not explicit. The explicit substantival connection is that the plough, like the nails in the cross, is a mechanism "fixed with pins" (tali confixus). ${ }^{114}$ The crucified body of Christ that is fashioned from the earth is fixed to the cross with iron pins, just as a plough, and it combines wood and iron as a means to till the earth. But even more specifically,

\footnotetext{
${ }^{110}$ Orbe, Teología IV, 476 n. 42. cf. I Apol, 55.

${ }^{111}$ The language of "semination" (seminationem) has roots in Middle-Platonism as expressed in Justin's thought, but here we find scriptural background. M. Edwards, "On the Platonic Schooling of Justin Martyr," TS 42.1(1991): 17-34.

${ }^{112}$ This agricultural imagery calls to mind the language of Gen 2:5 where no one was found to work the ground and the planting of the Garden in Gen 2:8.

${ }^{113}$ Orbe, Teología IV, 476 n. 43.

${ }^{114}$ Orbe only discusses their connection in form. Orbe, Teología IV, 476 n. 46.
} 
Christ's atonement "cleaned the overgrown earth" (emundavit silvestrem terram). ${ }^{115}$ This cleansing overturns the curse God places upon the earth in Gen 3:17-18.

Alongside Adam, Irenaeus also links the "pruning hook" (falcem) to the protological imagery of Abel's murder, which typifies the apostolic preaching leading to the gathering of the righteous. ${ }^{116}$ He appeals to the imagery of Isa 57:1 that contemplates the trouble of a righteous person dying with no recompense or justification. The reason Irenaeus turns to Abel for the "prunning hook" imagery is that a pruning hook performs the function of cutting or trimming vegetation. It is Cain who, in a sense, "pruned back" the innocent Abel and cut short his life. The death of Abel, therefore, anticipates and prefigures the ingathering of the righteous through the salvific work of Christ. Irenaeus is, however, quick to point out that the liberation of the righteous from evil was anticipated before Abel, declared by the prophets, and accomplished in the person of Christ. ${ }^{117}$ Therefore, having utilized his intertextual argumentation Irenaeus draws together Gen 2:7, Isa 2:3-4, Isa 57:1, Matt 5:39, John 4:37, and the narrative of Abel's murder in Gen 4 to depict the prophetic fulfillment of a bodily resurrection and the salvation of the righteous.

\subsection{AH 4.36.2-6: Christ's Parables and Adam (Gen 2:7)}

In this section, Irenaeus relates a series of parables depicting, in various ways, the narrative of salvation history. At three distinct points, $A H 4.36 .2,4$ and 6, an echo or allusion to Gen 2:7 surfaces within the flow of Irenaeus' argumentation. In each of these instances, there is a reference to Adam as the "formation" (plasma) of God. In AH 4.36.1-2, he relates the parable of the wicked tenants in Matt 21:33-43. The master of the house in the parable is the Father, the vineyard is the human race, the servants are the prophets, and the son is Christ. In terms of the allusion to the formation of Adam, Irenaeus writes, "For God planted the vineyard of the human race when at the first He formed Adam and chose the fathers" (Plantavit enim Deus vineam humani generis primo quidem per plasmationem Adae et electionem patrum). ${ }^{118} \mathrm{He}$ spiritualizes the interpretation by connecting the formation of Adam with the

\footnotetext{
${ }^{115}$ Although it is not noted in $S C$ or $B P$, this must be an echo of Gen 3:17-8 and the effects of the curse upon the ground.

${ }^{116}$ cf. Gen 4:10.

${ }^{117} \mathrm{cf}$. AH 4.30.4.

${ }^{118} \mathrm{AH}$ 4.36.2.cf. AH 4.14.2.
} 
planting of the vineyard. While Irenaeus sometimes uses the "vineyard" imagery for the nation of Israel, here the imagery reflects humankind in general. ${ }^{119}$ But he also joins this interpretation of the vineyard with the echo of the calling of the patriarchs. This short echo alludes to texts such as the calling of Abraham in Gen 12, which connects Irenaeus' interpretation of the parable with the trajectory of salvation history, so that Gen 2:7 is understood in terms of its relationship to the narrative history of salvation.

Following his spiritual interpretation of the parable of the wicked tenants, in $A H 4$ 46.4, Irenaeus provides a series of warning passages predicting the judgment of those who reject the true God. He cites several passages including: Luke 21:34-35, Luke 7:35-36, Matt 24:42, Matt 11:23-24, and especially the reference to the "days of Noah" (temporibus Noe) in Luke 17:2-6. ${ }^{120}$ Irenaeus takes up the interpretation of the "days of Noah" (temporibus Noe) in connection to the Nephalim in Gen 6:2-4. He describes the wickedness of the people following this episode in Gen 6:5 and suggests that because the angels sinned in comminging with the sons of Adam, God brought on the deluge in order to restrain the sins of humanity and "preserve the true archetype, the formation of Adam" (servaret vero archetypum, Adae plasmationem). ${ }^{121}$ Orbe notes a possible alternate reading for "archetype" (archetypum) as arcae typum, or the "form of the ark." In the former case, God destroys sinful humanity while at the same time preserving a purified form of the nature and character of the one formed from the dust. The latter case, on the other hand, actually applies the imagery of "ark" (arcae) to the human form fashioned from the dust, so God preserves the figure of the ark, the human form. ${ }^{122}$ Although this alternate reading is possible and appealing in some respects, the reference to Adam seems to imply the original formation and thus the "archetype." The argument of this section joins this flood narrative with the destruction of Sodom and Gomorrah to express the idea that God privileges those who believe in him and judges those who reject him.

\footnotetext{
${ }^{119}$ Orbe, Teología IV, 487 n. 37.

${ }^{120}$ Matt 11:23-24 evokes the imagery of Sodom and Gomorrah, which parallels the discussion of Noah in AH 4.36.3-4. In the immediate context, he also alludes to John 4:14, Matt 21:19, 2 Thess 1:5, Matt 3:10 and Matt 7:19. But these passages have only loose theological connections to the echo to Gen 2:7. ${ }^{121}$ AH 4.36.4.

${ }^{122}$ Orbe, Teología IV, 491 n. 72. Orbe points to Hugo Rahner analysis of sea symbolism in patristic thought see, H. Rahner, Symbole der Kirche (Salzburg: Otto Muller, 1964), 272-303, 516.
} 
Finally, in $A H$ 4.36.6, Irenaeus continues the theme of judgment with another echo of Gen 2:7 within a discussion of Psalm 23:1 LXX, Matt 5:45, Matt 22:7, and Rom 13:1-6. In continuity with the previous sections, he argues that God has providence over all things and administers his provision and retribution judiciously. For those who are ungrateful, Irenaeus writes that God "sent his armies" (mittens exercitus suos, Matt 22:7) to impose the penalty of his wrath. He focuses on the possessive pronoun "his" (suos) to argue this reveals all humankind is the property of God because God is their Creator. He supports his point with citations of Psalm 23:1 LXX and Rom 13:1-6 to argue the earth and everything within it including the powers and authorities are all subject to the administration of their Creator. This is also why, following the allusion to Rom 13:1-6, he describes the activity of God within salvation history in summary fashion including mention of the giving of the Law, the sending of the prophets, and the creation of all things. He also concludes with another reference to "his armies" (exercitus suos) in Matt 22:7 alongside an echo of Gen 2:7, saying that they are "his" (suos) armies because every human is his own creation even though they may be ignorant of this fact (Gen 2:7). ${ }^{123}$ To emphasize the inclusiveness of God's creative acts, he closes with the description of God causing the sun to rise on the evil and the good and sending rains upon the just and unjust alike (Matt 5:45). Once again the formation from the dust in Gen 2:7 contributes to the theological argumentation and intertextual interpretation, by means of unifying all humanity in the original formation from the earth in Gen 2:7.

\subsection{AH 4.37.4: Image, Likeness, and Freedom (Gen 1:26)}

The broader focus of this passage considers why God made humankind free. In $A H$ 4.37.1-2, he argues that God's will is good and he grants humankind the power of free choice, in order that God might judge them justly. In AH 4.37.3, he laces together several passages expressing the independent will of humankind, while in AH 4.37.4 he organizes a series of texts to communicate human's power to disobey God. AH 4.37.1 begins by citing Christ's desire to gather up his children in Matt 23:37, suggesting that this expression, which communicates the "ancient law of human liberty" (veterem legem libertatis hominis, Gen 2:17-18) necessitates human

\footnotetext{
${ }^{123}$ AH 4.36.6.
} 
beings possess free will from the beginning. ${ }^{124} \mathrm{~A}$ similar phrase is echoed at the conclusion of AH 4.37.4, only in this case, Irenaeus uses the language of "likeness" (similitudinem, Gen 1:26). He suggests humanity has the power to freely act in accordance with the divine command or reject God outright. This is because, alluding to Gen 1:26, in the beginning humankind was created with "free will" (liberae sententiae) in the "likeness" (similitudinem) of God because God possess "free will" (liberae sententiae). However, even though they possess free will humankind is subject to the nature of the divine economy, while God is not. ${ }^{125}$ As rational creatures within God's economy (not irrational as other created substances), human beings have the ability to differentiate between good and evil works. Those, according to Irenaeus, who of their own free will choose to be disobedient toward God will be subject to God's judgment, while those who choose to be obedient to God will be granted divine blessing. For Irenaeus, the nature of free will in humankind, which they have possessed from the beginning, is validated by the myriad of scriptures that petition the faithful in obedience to commands of God. He reasons that Paul would not give the faithful these examples to practice and abstain from certain practices (contra Gnostic asceticism), if they did not possess the capacity to do so. Irenaeus exemplifies this concept of universal human freedom with allusions to 1 Cor 6:12, Eph 4:25, Eph 4:29, Eph 5:8, and 1 Pet 2:16. All of these passages support the concept of humans as created in the likeness of God and possessing the power to act freely from the beginning.

\subsection{4 $\mathrm{AH}$ 4.38.1-4: Perfection in the Image and Likeness of God}

As we have seen in earlier sections, God was motivated to create beings that might partake in divine glory. In continuation of this theme, AH 4.37-9 considers the "ancient law of liberty" (veterem legem libertatis). ${ }^{126}$ He raises the question of the imperfection of Adam and Eve in Genesis and considers why God did not create them perfect, or as "gods" (deus), in the beginning. ${ }^{127}$ While Irenaeus acknowledges that all things are possible with God, he instead appeals to the distinctive natures of Creator and creature. He emphasizes, contra the Valentinians, the corporeal nature

\footnotetext{
${ }^{124}$ AH 4.37.1; Orbe, Teología IV, 508 n. 29.

${ }^{125}$ AH 4.37.4.

${ }^{126}$ AH 4.37.1; Behr, Asceticism, 44; Constantelos, "Irenaeus of Lyon," 355-56.

${ }^{127}$ AH 4.38.4.
} 
of Adam and his capacity to become accustomed to divine immortality. ${ }^{128}$ Here again we encounter the contrast between divine aseity and human necessity; for Irenaeus the creature could not be created perfect in the same sense as the Creator. A creature is by nature inferior to his or her creator, because he or she is of a more recent origin. For this reason the first couple in Genesis was "infantile" (infantilia) and "unaccustomed to and unexercised in perfect discipline" (insueta et inexercitata ad perfectam disciplinam). ${ }^{129}$ The first couple is, as Behr suggests, categorically "imperfect" in the sense that they require growth and logically subject to the conditions and properties of their nature as a created substance. ${ }^{130}$ Created substances are subject to time, change, and require growth from imperfection to perfection. ${ }^{131}$ In this context, Irenaeus combines an echo of the formation of humankind in Gen 2:7 with 1 Cor 3:2-3 and Heb 5:12-14 in AH 4.38.1-2 to examine the infantile nature of Adam and Eve that necessitated growth and maturity toward perfection in the divine life. ${ }^{132}$ Then, in AH 4.38.3, he weaves together Gen 1:26, Gen 1:28, Gen 2:7, and Wis 6:19 as exemplary of the harmonious creation where Adam and Eve were perfectly situated to receive growth and advancement towards God. Finally, in AH 4.38.4 his combination of Gen 1:26, Gen 3:5, Psalm 81:6-7 LXX, and 1 Cor 15:53 anticipates the future resurrection and glorification of the faithful who are at last perfected in the image and likeness of God.

\subsubsection{AH 4.38.1-2: Ascendancy Toward Perfection (Gen 2:7)}

This section has been the source of much debate going back to the work of Wendt and his fundamental distinction between the restorative and transformative line of Irenaean soteriology. ${ }^{133}$ Wingren corrected Wendt by noting the concept of "growth" and the formation of Adam as a "child" to be the formal link between this soteriological bifurcation. ${ }^{134}$ Steenberg's treatment of Adam and Eve as infants begins with a citation of this passage, but he neglects the argument of Wendt (or Harnack's reception of it), instead preferring to question to philosophical nature of the imperfection of creation. Steenberg regards $A H 4.38 .1$ as the "single most

\footnotetext{
${ }^{128}$ Orbe, Teología IV, 513 n. 2, 519-20.

${ }^{129}$ AH 4.38.1.

${ }^{130}$ Behr, Asceticism, 46-7; See also Dennis Minns, Irenaeus, 73-4.

${ }^{131}$ Orbe, Teología IV, 513 n. 3-4.

${ }^{132}$ Orbe identifies an echo of Heb 7:19 in the language proximamus as Deum.

${ }^{133}$ H. H. Wendt, Die christlich Lehre von der menschlichen Volkommenhiet (Göttingen, 1882), 22.

${ }^{134}$ Wingren, Man and the Incarnation, 101.
} 
important passage" in the discussion of Adam and Eve as children in paradise. ${ }^{135}$ These studies reveal the significance of this section, but neglect Irenaeus' intertextual references mutually interpret the echoes of Gen 1-2. Alluding to the nature of God's formative creation of Adam in Gen 2:7, Irenaeus suggests that the infantile and corporeal form in which Adam was fashioned was incapable of receiving the full divine perfection God might grant. He reasons that even if God granted Adam complete divine perfection, his infantile, corporeal nature could not have contained divine perfection, much less managed to retain it throughout their lives. ${ }^{136}$ The infantile nature of the first couple in the pre-lapsarian state simply could not bear God's divine perfection. Furthermore, the Son of God came into the world as an infant, Irenaeus adds, to prepare humankind to receive God from the beginning. ${ }^{137}$

In the flow of Irenaeus' argument, the nature of Adam and Eve's infantile creation in Gen 2:7 is supported by several Pauline allusions. In AH 4.38.1-2 he illustrated this ascendancy toward perfection by alluding to a baby that is nourished with his mother's milk before receiving strong food, derived from 1 Cor 3:2-3 and Heb 5:12-14. ${ }^{138}$ In a similar way, the Son prepares the faithful for immortality through nourishment that increases during the course of life. The passages are linked through the concepts of the immature nature of Adam in Gen 2:7 and the imagery of infant food and drink in 1 Cor 3:2-3 and Heb 5:12-14. The "milk" (lac) of 1 Cor 3:2 is the advent of the Lord while the "meat" (escam) is the reception of the Spirit. Irenaeus identifies those whom Paul chastens in 1Cor 3:3 as the ones who had acquaintance with the apostolic teaching but have dissensions among them because they have not received the Spirit. Paul had the power to give them strong meat (1 Cor 3:2), because the apostleslaid hands on people and imparted the Holy Spirit who is the "food of life." Not everyone, however, was able to receive the Spirit. Alluding to the narrative of Acts 8:17-19, Simon the Magician could not receive the Spirit from Peter and John and, as a result, offered to pay money to posses the Spirit. The only other uses of this passage are located in Irenaeus' anti-Gnostic polemic. ${ }^{139}$ In

\footnotetext{
${ }^{135}$ Steenberg, "Children in Paradise," 15.

${ }^{136}$ AH 4.38.2.

${ }^{137}$ Orbe makes the intriguing connection to the description of the Lord's growth in wisdom in Luke 2:40. He points to Justin for a similar comparison in Dial 88.2; Orbe, Teología IV, 517 n. 30.

${ }^{138}$ AH 4.38.2.

${ }^{139} \mathrm{AH} 1.23 .1 ; \mathrm{AH} 2.32 .3$.
} 
essence, Irenaeus compares those who are not able to receive the Spirit, such as Simon and those at Corinth, to the original formation of Adam that was undisciplined and incapable of receiving the divine perfection. ${ }^{140}$

\subsubsection{AH 4.38.3: Growth, Perfection, and the Original Creation (Gen 1:26, Gen 1:28, Gen 2:7)}

As we have seen the creation of Adam is not a singular event of a purely transcendent deity, but the activity of an imminent Creator working with the very matter of creation. It is, as Behr describes, a "hands-on affair." ${ }^{141}$ The "hands" imagery is a classic Irenaean anthropomorphic image of God and the only consistent anthropomorphism he uses to depict the creative activity of God. ${ }^{142}$ The interTrinitarian creation of Adam is portrayed clearly in AH 4.38.3 with the Father commanding the Son and the Spirit, the Son performing the work of creation, and the Spirit nourishing all that is created. The dynamism of this divine activity produces a formation fittingly positioned for growth and perfection. The personal activity of God and the progressive nature of human perfection is, for Irenaeus, grounded in the textual references to Gen 1:26, Gen 2:7, Gen 1:28 and Wis 6:19. He argues God's power and goodness are simultaneously exhibited in a harmonious creation fashioned ex nihilo. With an intricate intertextual weaving, Irenaeus depicts the divine activity in the harmonious creation of Genesis 1-2. The nature of Irenaeus' intertextual reading is a natural consequence of his anthropological perspective of the ascendancy towards perfection reflected in this Trinitarian reading of Gen 1:26, Gen 1:28, and Gen 2:7. The opening lines set the stage of Irenaeus' harmonious (convenientiam) economic understanding of history as the inter-Trinitarian activity moves humanity progressively toward the divine life. ${ }^{143}$ In the earlier portion of this chapter, he has already described how all creation itself is one harmonious and consistent whole. ${ }^{144}$ This extended chronological trajectory orients the faithful towards growth into the image and likeness of God. The allusion to Gen 1:26, with its declaration of creation in the image and likeness of God, initiates the actualization of creation in Gen 2:7 and the augmentation of creation in

\footnotetext{
${ }^{140}$ AH 4.38.2. cf. Acts 8:17-19.

${ }^{141}$ Behr, Asceticism and Anthropology, 38.

${ }^{142}$ Fantino, Théologie d'Irénée, 306.

${ }^{143} \mathrm{AH} 4.38 .3$.

${ }^{144}$ AH 4.38.3.
} 
Gen 1:28. Irenaeus frames these three texts (Gen 1:26, Gen 2:7, and Gen 1:28) with an economic Trinitarian perspective with the Father planning and commanding (Gen 1:26), the Son executing and performing the work of creating (Gen 2:7), and the Spirit nourishing and increasing the creation (Gen 1:28). ${ }^{145}$ This theological and intertextual depiction of creation orients humanity toward the "growth" of humankind in the image and likeness of God. Steenberg highlights the relationship between Gen 1:26 and 2:7, but neglects to frame all three texts in their proper theological interaction. ${ }^{146}$ Irenaeus describes this ascendancy toward perfection in terms of developmental stages from creation to glorification and immortality using Gen 1:28. ${ }^{147}$ Deification, for Irenaeus, is not an instantaneous event, but an incremental process. The process begins, Irenaeus suggest, with the creation (factum) of humanity, which most naturally refers to Gen 2:7. This is followed by a series of stages including: "grow" (augeri), "strengthen" (corroborari) $)^{148}$, "abound" (multiplicari), "recover" (convalescere), "glorify" (glorificatum), and the final stage of seeing (videri) God. The two initial commands of Gen 1:28: "be fruitful” (augeri) and "multiply" (multiplicari) are linguistically connected to the aspects of growth and abounding in this progression in sanctification. ${ }^{149}$ Although he neglects the connection to "growth" (augeri), Orbe identifies "abound" (multiplicari) as an allusion to Gen 1:28 and interprets this as a reference to multiplication through procreation. ${ }^{150}$ Given the connection to Gen 1:28 and the scale of sanctification, it is difficult to imagine that Irenaeus merely has procreation in view. Instead, what we see here is how Gen 1:28 in continuity with Gen 1:26 and Gen 2:7 forms a sanctifying paradigm for human history that assumes procreation, but is more concerned with the historical nature of salvation. What is perhaps most interesting is the qualification "strengthen" (corroborari) that is situated between these texts, and "recover" (convalescere) that follows afterwards. The former term is found in references to the sinful state of humankind necessitating strength to overcome their lowly state. Irenaeus frequently uses the language of "strengthen" (corroborari)

\footnotetext{
${ }^{145}$ Holsinger-Friesen assumes Irenaeus imposes the notion of ascendancy on Gen 1:26, but clearly this notion is drawn from Gen 1:28. Holsinger-Friesen, Irenaeus, 136-137.

${ }^{146}$ Steenberg, Irenaeus, 106.

${ }^{147}$ Behr, Asceticism, 124-5.

${ }^{148}$ The verb $\sigma \theta \varepsilon v o ́ \omega$ is only found in 1 Pet 5:10 as part of a description of the perfection and glorification of the faithful.

${ }^{149}$ The succession comprises: creation, growth ( $\left.\alpha \dot{u} \xi \tilde{\eta} \delta \alpha \mathrm{l}\right)$, strengthen, multiply ( $\left.\pi \lambda \eta \theta u v \theta \tilde{\eta} v \alpha \mathrm{l}\right)$, recover, and be glorified. The term $\alpha \dot{u} \xi \tilde{\eta} \delta \alpha 1$ is only found in Eph 4:16 and Col 2:19. See AH 4.32.2

${ }^{150}$ Orbe, Teología IV, 517 n. 32.
} 
to characterize the depraved state of humanity that requires the impartation of the Spirit. ${ }^{151}$ The latter term, "to recover" (convalescere), according to Orbe, is equivalent to maturity that prepares the faithful for the next stage of glorification. ${ }^{152}$ The emphasis on maturity is helpful, but must be understood soteriologically and Christologically. Elsewhere Irenaeus describes the "recovery" of the image and likeness in Christ that was lost in Adam. ${ }^{153}$ So it is not merely maturity, but soteriological restoration of the image and likeness that was lost in Adam's disobedience. Therefore, whereas growth characterizes the pre-lapsarian state, in the post-lapsarian state the disobedient Adam and Eve require strengthening and multiplication as God prepares the humanity for recovery and glorification throughout salvation history. These texts, joined with Wis 6:19 depict the deification and glorification of the faithful who partake in immortality. In this sense, Gen 1:26 and Wis 6:19 form the bookends of Irenaeus' anthropological progression toward immortality, while the language of creation in Gen 2:7 is complemented by the progressive language of Gen 1:28 that anticipates the glorification and salvation of the faithful.

\subsubsection{AH 4.38.4: Resurrection and Glorification (Gen 1:26, Gen 3:5)}

In the final paragraph of $A H 4.32 .4$, Irenaeus concludes his discussion of the perfectible nature of humankind. For Irenaeus, God's goodness endowed humankind with free will that allows growth and development into the divine likeness. Contra the Valentinians, salvation history comprises a single linage of corporal humanity (rather than three distinctive human natures) that follows a trajectory culminating in the salvation and deification of the faithful. God did so, Irenaeus argues, because human nature could not have sustained the power of divinity if God had given it to them. It was not out of envy or rivalry that God did not make humanity gods in the beginning, but out of goodness and compassion. This reality, for Irenaeus, is expressed most clearly in Psalm 81:6-7 LXX, which is read in continuity with Gen 1:26, Gen 3:5, and 1 Cor 15:53. Psalm 81:6 LXX and the proclamation "You are gods"

\footnotetext{
${ }^{151}$ cf. 3.6.4 3.12.3,6, 3.19.3, 3.20.1-3, 4.6.2, 4.33.11, 5.2.3, 5.3.1. In AH 3.5.2 he cites the Lord's description of himself as a physician come to heal the sick and, in the next paragraph, describes the work of God over creation saying God "by means of His creation, did nourish, increase, strengthen, and preserve them" (per conditionem suam aleret et augeret et constabiliret et eis esse praestaret). The reason for this act of preservation is so that the faithful might be prepared for glorification.

${ }^{152}$ Orbe, Teología IV, 517 n. 33.

${ }^{153}$ AH 3.18.1.
} 
(Dii estis) depicts the goodness of God in the divine promise of deification and glorification of the faithful, while Psalm 81:7 LXX reflects upon the infantile nature of humankind that could not possibly bear the power of divinity because they will "die as humans" (velut homines moriemini) and be subject to the conditions of mortality. ${ }^{154}$ The reason Irenaeus emphasizes the teaching of the Psalmist is that, contrary to the Valentinians, the God of the Old Testament makes this proclamation. Therefore, deification, in Irenaeus' reading, was not a revelation peculiar to the New Testament or Pauline literature, but was taught by the Psalmist and, more importantly, characteristic of the creation accounts themselves. Deification is a process that began at the origin of creation itself. Through his reading of Psalm 81:6-7 LXX, Irenaeus laces together 1 Cor 15:53, Gen 1:26, and Gen 3:5, and these texts reflect a narratival trajectory from creation to immortality mirrored in the two-fold reality of Psalm 81:6-7 LXX. In the first creation, humankind is born with freedom, which is why they are described as being given the knowledge of good and evil. The means of the human progression toward deification is a system based upon freedom. As Behr argues, this economic appreciation for experiencing good and evil implies that human person must become completely involved in the activity of this present life. ${ }^{155}$ It is a system of merit where those who are faithful towards God receive the blessing of divine likeness. This eschatological reality is, for Irenaeus, also depicted in 1 Cor 15:53 when the death, which is mentioned in Psalm 81:7 LXX, is overcome and the believer is resurrected in the image and likeness of God. Linking these texts Irenaeus also communicates how freedom not only characterizes the original creation, expressed in the Gen 1:26 and Gen 3:5, but that the eschatological vision of these passages, read in continuity with 1 Cor 15:53, implies that human freedom remains in the sanctified, resurrected state. ${ }^{156}$ Taken together these texts are all understood in terms of order and a salvific trajectory where Gen 1:26, Gen 3:5, and Psalm 81:7 LXX portray the original nature and destiny of the human creature that, conditioned by free will, anticipates participation in the divine nature as expressed

\footnotetext{
${ }^{154}$ Orbe, Teología IV, 519 n. 45.

${ }^{155}$ Behr, Asceticism, 125.

${ }^{156}$ Orbe, Teología IV, 519 n. 47. Irenaeus has already argued extensively the commands of obedience in Paul validate the implicit freedom of human nature. $c f . A H$ 4.37.4.
} 
in Psalm 81:6 LXX, an eschatological reading of these creation, and the Pauline language of 1 Cor 15:53.

\subsection{AH 4.39.2: God Makes, Humanity is Made (Gen 2:5, Gen 2:7)}

Continuing his description of the freedom of human nature, in this portion Irenaeus emphasizes the necessity for humans to progress morally through obedience.

Following this Irenaeus suggests that to obey God is good and to disobey God is evil. Through experience with good and evil, human being become more resolute in their obedience toward God, which allows the creative hands of God to re-fashion the corruptible aspects of human nature. ${ }^{157}$ Anticipating the future second creation from the dust, where the faithful are resurrected and recreated in the image and likeness of God, Irenaeus offers a poetic description that blends together the imagery of the creation from the dust in Gen 2:7 with Exod 25:11 and Psalm 44:12 LXX.

The final re-creation, for Irenaeus is not a singular event set apart from the creative activity of God in the present, but in Gen 1:26 the Father's work of creation by means of the Son and the Spirit is a "continuous creation" throughout salvation history. ${ }^{158}$ This universal truth is summarized in the Irenaean axiom: "For you did not make God, but God made you" (Non enim tu Deum facis, sed Deus te facit). ${ }^{159}$ The unilateral creation of God in Gen 2:7 informs this saying and the designation of humanity as the "workmanship of God" (opera Dei). As a result, Irenaeus pleads with his readers to "await the hand of your maker" (manum artifices tui exspecta) referring to the "hand" (manum) of God that formed Adam in Gen 1:26. In continuity with his argument for patient, progressive sanctification and his understanding of the structure of the divine economy, he suggests that God creates everything in due time. ${ }^{160}$ Extending the imagery of Gen 2:7 to the present state of sanctification, he beseeches his readers to offer a softened, malleable heart to God so that they "preserve the form" (custodi figuram) in which the Creator has fashioned them. This form is characterized by "moisture" (humorem) that calls to mind the imagery of rain on the earth in Gen 2:5, which becomes clear in the next line when Irenaeus

\footnotetext{
${ }^{157} \mathrm{cf.}$. AH 4.11 .2

${ }^{158}$ Orbe, Teología IV, 524 n. 23.

${ }^{159}$ AH 4.39.2.

${ }^{160}$ Vogel, "The Haste of Sin, the Slowness of Salvation: An Interpretation of Irenaeus and the Fall and Redemption," AThR 89 (2007): 443-59.
} 
refers to the "moist clay" (lutum) of Adam's formation. ${ }^{161}$ This is the most illustrative use of the potter imagery that has characterized Irenaeus' interpretation of Gen 2:7 to this point. For Orbe, the reference to water in this context, which most naturally alludes to Gen 2:5, is a reference to the Spirit who, alongside the Son (cf. Gen 1:26), is active in the creation of Adam. ${ }^{162}$

On the other hand, those who remain hardened and obstinate towards God lose "the impressions of His fingers" (amittas vestigia digitorum ejus), because the Son and the Spirit are not actively forming them. ${ }^{163}$ In doing so, they "reject His workmanship" (respuas artem ejus) and will loose both God's "workmanship and life" (artem... et vitam). ${ }^{164}$ The language of artem and vitam refer back to the artful formation from the dust in Gen 2:7 where Adam became a living being. Thus, while creation may be motivated by the goodness of God, it is the nature of humanity to be created. ${ }^{165}$ Although it is clear that the "hand" (manus) of God is never separated from his creation, but actively involved in a continual act of creation, the key is the receptivity of the creature towards the Creator. The creature can become hardened and obstinate toward the Creator and in turn deny the formative presence of the Spirit. ${ }^{166}$ On the other hand, the faithful who are open and submissive to the Creator allow themselves to be fashioned by God. ${ }^{167}$

The creative imagery that characterizes Irenaeus' reading of Gen 1:26 and Gen 2:7 naturally evokes reference to the construction of the Ark of the Covenant in Exod 25:11 and the king's admiration for his bride in Psalm 44:12 LXX. ${ }^{168}$ With highly specific dimensions, Exod 25:10 describes how the ark should be formed out of wood, while Exod 25:11 directs Moses to cover the wood with a layer of pure gold. Irenaeus applies this imagery to the resurrected body, where God will figuratively cover the mortal form of flesh fashioned from feeble dust with a layering of "pure gold and silver" (auro puro et argento). The quality of the elements reflects the immortal nature of the resurrected body that receives the perfection God intended

\footnotetext{
${ }^{161}$ AH 4.39.2; Orbe, Teología IV, 524 n. 27.

${ }^{162}$ Orbe, Teología IV, 524 n. 23, n. 27-28.

${ }^{163}$ AH 4.39.2.

${ }^{164}$ AH 4.39.2.

${ }^{165} \mathrm{AH}$ 4.39.2. See a similar reference to goodness as the motivation for creation in AH 3.25.5. Steenberg, Irenaeus, 33.

${ }^{166}$ For the contrary positions on free will in Irenaeus and the Valentinians see: Orbe, Teología IV, 5278.

${ }^{167}$ Behr, Asceticism, 117.

${ }^{168}$ Orbe, "El hombre ideal en la teología de san Ireneo," Greg 43 (1962), 464-68.
} 
in Gen 1:26 and Gen 2:7. Likewise, Irenaeus also mentions Psalm 44:12 LXX, which compares a king's admiration for the beauty of his daughter to the beauty of the resurrected body and the pleasure God will take in the resurrected, perfected humanity. Steenberg submits that the concept of God's goodness motivating creation is borne principally out of the Gospels-not necessarily Gen 1-2-where the same substance of the flesh is assumed and recovered in the Incarnation, but in the present context we find that Exod 25:11 and Psalm 44:12 LXX describe the beautiful nature of God's creative activity. ${ }^{169}$ As we have seen above, when Irenaeus uses the language "creation" (facere) the creation accounts are at the forefront of his mind, but not the creation accounts alone. The original creation motivated by the goodness of God, initiates the active, ongoing work of creation in throughout time that gradually directs the believer towards perfection. The beauty of this creation is expressed in the imagery of Exod 25:11 and Psalm 44:12 LXX.

\subsection{AH 4.40.3: The Eschatological Judgment (Gen 3:15)}

The final allusion to Gen 1-3 in AH 4 is found in AH 4.40.3, where he argues God has prepared "good things" (bona) for those who remain faithful, but the Devil and those who rebel from God will be cast into the fire mentioned in Matt 25:41. ${ }^{170}$ In Irenaeus thinking, Adam and Eve's disobedience was not the result of a self-motivated rebellion, but of the schemes of a carefully calculating provocateur. Certainly Adam and Eve's immaturity contributed to their indiscretion, and they (and their posterity) remain culpable for their actions, but for Irenaeus, this deceiver, rather than the humans, receives full measure of God's retribution. ${ }^{171}$ The larger section explains the nature of divine justice, so in $A H 40.1-2 \mathrm{a}$ he details this eschatological division of persons and in $A H 4.40 .2 \mathrm{~b}-40.3$ he discusses the parable of the wheat and the tares in Matt 13:24-30; 36-43. ${ }^{172}$ Amid his exposition of the parable, Irenaeus turns the discussion from the eschatological judgment toward a reflection upon the original enmity in Gen 3:5.

Irenaeus opens $A H 4.40 .3$, with the citation of Matt 13:24, where Christ interprets the parable and identifies the Lord as the one who sows the good seed

\footnotetext{
${ }^{169}$ Steenberg, Irenaeus on Creation, 33.

${ }^{170}$ AH 4.40.1.

${ }^{171}$ Victor K. Downing, “Doctrine of Regeneration in the Second Century,” ERT 14.2 (1990): 99-112, 110.

${ }^{172}$ Bingham, Irenaeus' use of Matthew's Gospel, 50.
} 
and links the "field" (ager) with the "world" (saeculum). Here he moves the discussion from the parable in Matt 13 to the narrative of apostasy in Gen 3:1-6. Envious of Adam as God special creation, the Devil (the enemy of Matt 13:25) came and sowed tares in the Garden that produced Adam and Eve's transgression in Gen 3:6. Through his actions the enemy of God desired to introduce enmity between God and humanity, thereby upsetting their privileged relationship. The devil, however, failed to inflict enmity between God and humanity because he had compassion on the first couple and, as a result, the responsibility of the transgression fell upon the serpent. According to Irenaeus, Adam did not desire to commit apostasy against God, but rather was deceived by the enemy of God. ${ }^{173}$ Following Adam and Eve's transgression God banished the Devil from his presence (cf. Gen 3:14-5, Matt 13:42) and, what is more, the work of Christ overturns the enmity the Devil desired to inflict between God and humanity. According to Irenaeus, the means of the overturning of this enmity is the Incarnation where Christ was born of a woman" (de muliere factus, Gal 4:4). The act of apostasy begins with the serpent conquering the woman (Gen 3:6) and concludes with a woman gaining victory over the snake (Gal 4:4). ${ }^{174}$ In this sense, Irenaeus implies the Incarnation is the fulfillment of serpent's destruction in Gen 3:15. The vengeance of God that the Devil desired to come upon Adam and Eve by making them the "enemy of God" (inimicum Deo), was instead enacted upon Satan for his principal role in the transgression. For this reason, the Devil and his angels are subject to judgment and cast into the fire (cf. Matt 13:41, Matt 25:41).

\subsection{Conclusion}

Having evaluated the performance of Gen 1-3 in AH 4, it is evident that at every turn Irenaeus conflates and harmonizes the texts and images of Gen 1-3 within the flow of his theological arguments. In most instances there is no introductory formula to signify a reference to Genesis. Instead the imagery and patterns of these texts simply weave their way into the flow of his argumentation. Beginning with the early chapters, the references to Genesis support his interpretation of select Gospel parables or the themes of inter-testamental unity and prophecy-fulfillment. First of

\footnotetext{
${ }^{173}$ Orbe, Teología IV, 532 n. 17-8.

${ }^{174}$ Orbe, Teología IV, 532 n. 20.
} 
all, in $A H 4$ Irenaeus extends his narratival arrangment of texts. In $A H 4.6 .2$, he reads the creative acts of God in succession including allusions to Gen 1:26, Gen 2:7, and Gen 1:28, and he also conflates this imagery of creation with his theology of recapitulation in Eph 1:10. In $A H$ 4.11.2, Irenaeus reads Gen 1:28 as a paradigm for human growth that is realized in the unfolding of salvation history. Throughout the growth of the divine economy, the ancients longed to see the advent of the Son (Matt 13:17).

Second, Irenaeus persists in using catchwords or linking terms to unite texts exegetically. In AH 4.20.1-4a the language of "all things" (omnia) unites a series of passages including: Mand 1, Mal 2:10, Eph 4:6, and Matt 11:27. He offers no commentary on these texts, but instead views the passages as themselves commentary upon the creation in Gen 1-2.

Third, Irenaeus provides a "plain sense" reading of Gen 1-3 that emphasizes the interpretation of these passages as a literal account of creation, without extended or explicit reference to texts outside of Gen 1-3. In AH 4.pf.4, Irenaeus conflates Gen 1:26 and 2:7 into one creation account of humankind, where the hands of God create Adam from the dust and in the image of God.

Fourth, Irenaeus continues to use a variety of conceptual, theological, or typological connections, which are crafted through his theological perspective and closely related to a particular aspect of the work of Christ. These conceptual connections do not imply hierarchy, and the texts of Gen 1-3 may serve as a primary or supportive text depending upon the context. His Christology informs his reading of the common glorification of the Father and the Son in John 17:5 as a means to interpret the motivation for God's creative acts in AH 4.14.1. Furthermore, the Creator-creature distinction established in Gen 2:7 informs a series of conceptually connected texts: John 17:24, Isa 43:5-7, and Matt 24:28. Through various illustrations, all three texts support the sufficiency of the Creator and the need for humanity to be glorified by the Father. He turns to Christology in his response to the Ebionites and describes how Christ must be greater than David, Solomon, Jonah, and even the evil one who subdued humanity (Matt 12:41-42, Matt 2:43, Matt 12:29), because humankind was formed in his image (Gen 1:26). In AH 4.33.4 he also conflates Isa 7:14, John 1:14, Gen 1:26, and Gen 2:7 to describe the salvific nature of the Incarnation. His eschatological interpretation of the Sabbath day of rest in Gen 
2:2-3 that is prevelant in $A H 5$ emerges in $A H$ 4.16.1. In this sense Gen 2:2-3 is a sign (Exod 20:12, Exod 31:13) that anticipates the conditions of life the faithful will enjoy when they dwell eternally in God's service (Matt 6:19 and Rom 8:36).

Fifth, the same prosopological (or prosopographic) style of reading continues in $A H 4$, where Irenaeus identifies the particular divine persons that are active in the creation texts. In $A H$ 4.pf.4. Irenaeus interprets the proclamation of Gen 1:26 as the two hands of God, the Son and the Spirit. Likewise, in AH 4.6.2 he converts the verbal forms of the acts of creation into titles for God as a means to identify the Creator. The same dialogical emphasis in located in AH 4.10.1 with an allusion to the Son of God inquiring after Adam in Gen 3:9. In AH 4.20.4, Irenaeus uses Prov 3:19-20, Prov 8:22-25, Prov 8:27-31 in connection with Gen 1:26 to explain the "Trinitarian" nature of God creating in Genesis, and likewise in AH 4.32.1 he alludes to John 1:3, Eph 4:5-6, 15-16, and Col 2:19 to argue that the Word of God is with the Father creating in Gen 1:3.

Sixth, Irenaeus frequently applies texts in an illustrative fashion, where various textual images are applied to the theological disputes and figures in his own contemporary setting. Appealing to the language of 2 Cor 11:3, in AH 4.pf.4 he observes that the Gnostics seek out ineffable mysteries, and carryout the same deception as the serpent in the Garden.

Seventh, Irenaeus uses the classical style of argumentation that moves from the general-to-particular. In AH 4.20.1-4, Irenaeus weaves together a set of texts that argue logically from the general concept that God created all things to the more particular point that God created humankind as a subset within the creation of all things (Acts 10:42, Rev 3:7, John 1:14, 1 Pet 2:23, and Col 1:18). These texts are not linked by any particular catchword, but conceptually describe the inclusive nature of God's creative activity and the power of the Son to accomplish the Father's creative will.

Eighth, he argues for a canonical arrangment of texts that intentionally links texts from various dispensations of salvation history. Most often this takes the form of stringing together texts drawn from the Prophets (old Testament), Gospels, and apostles. In AH 4.16.1 his eschatological reading of Gen 2:2-3 links Exod 20:12, Exod 31:13, Matt 6:19, and Rom 8:36. Irenaeus makes the same point when he links Mal 2:10, Matt 11:27, and Eph 4:6 in AH 4.20.1. These describe the creation of all things by 
means of the Word in Gen 1-2, and the truth of this reality is confirmed throughout every dispensation.

Throughout AH 4, Irenaeus' reading of Gen 1-3 builds steadly toward the final chapters, where he discusses the temporal ascendancy of humankind toward perfection in the image and likeness of God, the resurrected bodily form, and the eschatological judgment with the fulfillment of the serpent's destruction. In $A H 5$, however, the complexity of Irenaeus' theological treatment of these themes reaches its climax, and provides the most detailed and extended intertextual reflection on these early chapters of Genesis. 


\section{CHAPTER 6: THE INTERTEXTUAL RECEPTION OF GENESIS 1-3 IN BOOK 5 OF ADVERSUS HAERESES}

\subsection{Introduction}

As we have seen in the previous chapters, there is an intertextual logic to Irenaeus' exegesis. The final book in Irenaeus' five-part refutation of the Gnostics presents a fitting conclusion and culmination to his intertextual reception of Gen 1-3. This chapter provides the most consistent and extensive set of intertextual relationships formed with Gen 1-3 than any of the previous books. With his Christology and theology proper firmly established in AH 3-4 and his anti-Gnostic polemical objectives still in view, the purpose of $A H 5$ is to solidify his refutation with a careful argument for the creation, preservation, and resurrection of the flesh that is in every respect the work of God. ${ }^{1}$

In light of the focus on the creation and preservation of the flesh, Gen 1-3 is pivotal. The creation accounts function as the authentic account of the creation, while at the same time they establish a prophetic paradigm anticipating the unfolding of salvation history and the nature of the eschatological kingdom. ${ }^{2}$ Orbe's extensive three-volume commentary on AH 5 continues to be an invaluable resource for understanding Irenaeus' argument. He organizes the book into three main sections: AH 5.1-14, AH 5.15-24, and AH 5.25-36. ${ }^{3}$ AH 5.1-14 discusses the resurrection of the flesh, contra the Gnostics, as the culmination of human salvation begun at creation. The second section, AH 5.15-24, argues for the harmony between the activity of the person and work of Christ in the Gospels and the original creation. Third, AH 5.25-36 focuses on Irenaeus' eschatological vision and treats a number of prophetic texts in light of God's progressive plan of redemption in salvation history. A short conclusion in AH 5.36.3 fills out the work with a summary of the essential argument for resurrection and the glorified body fashioned once again in the image of God.

\footnotetext{
${ }^{1}$ AH 5.15.2.

${ }^{2}$ AH 5.28.3.

${ }^{3}$ Orbe, Teología V.1, 14; W. Overbeck, Menschwerdung: eine Untersuchung zurliterarischen und teologischen Einheit des fünften Buches 'Adversus Haersus' des Irenäus von Lyon (Peter Lang, Bern, 1995).
} 
Within the structure of these arguments there are forty-eight allusions of Gen 1-3, which are found in half of the thirty-six chapters. ${ }^{4}$ He opens with a refutation of the docetic and dualistic perspectives of his opponents, then argues for the salus carnis which relies upon intertextual reading of Gen 1:26 and Gen 2:7. He utilizes several Genesis passages to depict the progressive nature of sanctification and respond to the Gnostic reading of 1 Cor 15:50. His argument in AH 5.15.2-16.2 offers an extended commentary on the theological interrelationship between the creation in Gen 1-2 and the healing of the blind man in John 9. He also concentrates on the nature and consequence of Adam's disobedience and Christ's ultimate triumph over Satan. The closing portion completes his refutation with an eschatological portrait of the Sabbath day of rest in Gen 2:1-3. In the closing lines he refers to Gen 1:26 and the final consummation when God's creatures will at last fulfill the Fathers intention and be made in the image and likeness of God. Within these theological discussions Irenaeus continues to utilize the variety of intertextual practices that have characterized his exegesis to this point including: organizational or structural functions, catchwords or linking terms, theological or typological analysis, illustrative application and general-to-particular arguments. Together, these classifications clarify in analytical terms precisely how Irenaeus reads scripture intertextually.

\subsection{AH 5.1.1-3: Valentinians, Ebionites, Adam and Christ (Gen 1:26, Gen 2:7,}

\section{Gen 3:1-6, Gen 3:24)}

Irenaeus commences AH 5 with formal defense for the necessity for the Incarnation in response to the Ebionites, Valentinians, and Marcion. ${ }^{5}$ Beginning in $A H$ 5.1.1 he argues that had not the Word become flesh, the revelation of God would have remained obscure and unattainable. ${ }^{6}$ The Incarnation is, for Irenaeus, instructive.

\footnotetext{
${ }^{4}$ AH 5.1.3; AH 5.2.1; AH 5.3.2; AH 5.5.1; AH 5.6.1; AH 5.7.1-2; AH 5.8.1; AH 5.10.1; AH 5.12.2; AH 5.14.2; AH 5.17.1; AH 5.19.1; AH 5.20.2; AH 5.21.1-2; AH 5.23.1-2; AH 5.24.3; AH 5.26.2; AH 5.28.3-4; AH 5.30.4; $A H$ 5.33.1-4. As in previous books, there are several references in $B P$ that were unidentifiable including: Gen 1:26 and Gen 2:7 in AH 5.11.2 (cf. 1Cor 15:49-50), Gen 3:19 in AH 5.17.1, Gen 3:1-6 in AH 5.24.3 (John 8:44), and Gen 1:26 and Gen 2:7 in $A H$ 5.33.1-4.

${ }^{5}$ AH 5.1.1-2.3. Sakari Häkkinen, “Ebionites,” in A Companion to Second-Century Christian 'Heretics,' 24778. Häkkinen suggests that he derived his views from a revised catalog of heresies developed from Justin's Syntagma. See also Orbe, "Errores de los ebionitas (Analisis de Ireneo, Adversus haereses, V, 1, 3)" Mar 41 (1979): 147-70.

${ }^{6}$ AH 5.1.1.

${ }^{7}$ Orbe, Teología V.1, 52-53.
} 
After all, Irenaeus reminds his readers that no one knows the mind of God or offers God counsel (Rom 11:34). With the revelation of the Word, however, one who has held council with God the Father (John 1:18) has joined the ranks of humankind and offered spiritual instruction. As a result the faithful, through communion with the Son of God (1John 1:6) are able to perform the commands of his teaching (James 1:22) and advance towards divine perfection. This sophisticated intertextual description of the incarnation's didactical nature forms the backdrop for Irenaeus' explanation of the content of Christ revelatory instruction.

He characterizes revelation of the Word with notions of salvific perfection in the image and likeness of God and redemption from apostasy, both of which comprise subtle echoes of Gen 1:26, Gen 2:7 and Gen 3:1-6. ${ }^{8}$ The echo of Gen 1:26 describes the qualitative nature of Adam's as being "formed after his [Christ's] likeness" (ad eum similitudinem facti, Gen 1:26). The reference to creation in the likeness of Christ is the qualitative description of humanity as "predestinated" (praedestinati) for immortality (Eph 1:11-12) by the "foreknowledge" (praescientiam) of the Father (1Pet 1:2) though the preexistent economic administration of the Word. ${ }^{9}$ The divine command in Gen 1:26 is not a momentary, impulsive decision, as it was for the Gnostics, but a carefully calculated salvific arrangement designed to lead humanity incrementally towards the divine likeness. ${ }^{10}$

Furthermore, in AH 5.1.1 Irenaeus' vision for humankind as a creature destined for immortality flows into an assessment of redemption from the apostasy committed in Gen 3:1-5, when the serpent "obtained dominion over us at the beginning" (initio dominabatur nostri). ${ }^{11}$ The redemption offered though Christ overcomes the Devil, who by means of cunning persuasion, captured humanity and tormented God's creatures until the Incarnation. As we have seen in several cases, the human person is the "ancient handiwork of God" (antiqua plasmatio Dei), which always connotes the physical body of Adam fashioned from the dust in Gen 2:7.12 When Christ assumed humanity, he became the means of physical redemption. Twice in this context Irenaeus characterizes redemption from apostasy with the

\footnotetext{
${ }^{8}$ While Orbe identifies this as an allusion to Gen 1:26 it is not mentioned in BP or SC. Given the contextual description it seems certain Irenaeus has the imagery of Gen 1:26 in view. Orbe, Teología V.1, 60-1; See also Fantino, L'homme, 114.

${ }^{9} \mathrm{cf.}$. AH 4.38.3, James 1:18.

${ }^{10}$ AH 1.5.5; AH 1.18.2; AH 1.24.1-2; AH 1.30.6.

${ }^{11}$ AH 5.1.1.

${ }^{12}$ Orbe, Teología V.1, 87. cf. AH 3.18.7; AH 4.36.2,4; AH 5.14.1-2; AH 5.15.3; AH 5.21.1.
} 
blood redemption language of Eph 1:7 and the ransom text of 1 Tim 2:6. ${ }^{13}$ Through his death and resurrection Christ offered himself as a "redemption" (redemptionem) payment to the Father for all those who had been led into captivity through the exploits of the devil.

This summary of the divine vision for creation and redemption serves as the preface to his critique of the docetic Valentinians in AH 5.1.2 that suggested the Word only appeared to become incarnate, but did not in reality assume flesh. Against the Valentinian docetism he adds another brief allusion to Gen 2:7. If Christ merely appeared to become incarnate then it is logical to assume he received nothing from Mary. However, the redemption of the body necessarily assumed that he received from Mary true flesh and blood. In so doing, he recapitulated in himself (Eph 1:10) the "ancient formation of Adam" (antiquam plasmationem Adae). ${ }^{14}$ For Irenaeus, it is not logically consistent that Christ could recapitulate Adam's formation in himself only in appearance and, more to the point, he could not merely appear to redeem the body that is subject to death. He must do so in reality, which means he must have assumed in himself the substance of Adam's flesh.

While the Valentinians deny the humanity of the incarnate Word, the antithetical error is the Ebionite refusal to accept the deity of Christ. The Ebionites regard Jesus as the Messiah, but reject the virgin birth. ${ }^{15}$ Orbe isolates some interesting linguistic parallels in first and second part of $A H$ 5.1.3, which correspond to Irenaeus' polemical summary with his theological rebuttal. ${ }^{16}$ The result of his theological argumentation is a concluding demonstration of the efficiency of the "Hands of God," (drawn from a citation of Gen 1:26) to execute the will of God. Irenaeus' polemic is, of course, laced with Genesis creation imagery and set in continuity with Luke 1:35, John 1:13, 1 Cor 5:7, and 1 Cor 15:22. ${ }^{17}$

For Irenaeus, the Ebionite denial of the Incarnation is more fundamentally a denial of the potentiality for union, or "mixture" (commixtionem), between God and the human person. ${ }^{18}$ He lays out the ontological problem with this view using, first

\footnotetext{
${ }^{13} \mathrm{SC}$ notes Col 1:14, but the redemption language of sanguine alludes to Eph 1:7.

${ }^{14}$ AH 5.1.2

${ }^{15}$ Häkkinen, "Ebionites," 247-78. Irenaeus is the first to mention the Ebionites among his analysis of heretics and we have seen him do so on several occasions: AH 1.26.2, 3.11.7, 3.21.1, and 4.33.4.

${ }^{16}$ Orbe, Teología V.1, 88-89. The two sections comprise SC 153.24.61-26.71 and SC 153.26.71-83.

${ }^{17}$ AH 5.1.3.

${ }^{18}$ Here Irenaeus appears to be employing Eucharist imagery with the composite nature of wine, verses mere water. For the complex interpretation of this term see Orbe, Teología V.1, 101-2.
} 
of all, the Pauline culinary imagery of bread-making in 1 Cor 5:6-7. ${ }^{19}$ The rejection of the union of God and man in the person of Christ, for Irenaeus, implies the Ebionites "remain in the old leaven of birth" (veteri generationis perseverantes fermento).

Following Orbe's scheme, this imagery of 1 Cor 5:7 is paralleled with Adam who was “conquered" (victus, Gen 3:6) and "expelled from paradise" (projectus es de paradiso, Gen 3:23). ${ }^{20}$ For Irenaeus, the old leaven of 1 Cor 5:7 illustrates Adam's post-lapsarian condition. All humankind, including the Ebionites, who are in the line of Adam, inherits the nature of this condition.

The metaphor of leaven and bread-making in 1 Cor 5:7 and the nature of Adam's fallen human condition naturally leads into the imagery of human-making in Gen 2:7 and Luke 1:35. Not only do the Ebionites rebuff the proper understanding of Adam's fallen nature, but they also misunderstand the creative performance of the Word and Spirit from the creation to the Incarnation. ${ }^{21}$ By means of the dialectical Adam-Christ typology (Rom 5:12, 1Cor 15:22), Irenaeus oscillates between Adam's "formation" (plasmationis) in the "beginning” (initio, Gen 2:7), and Christ's formation in the "end" (fine, Luke 1:35).

Beginning with the creation in Adam, he alludes to the flesh as the "ancient substance of Adam's formation" (antiquae substantiae plasmationis Adae, Gen 2:7). The term plasma is a way Irenaeus identifies the solidarity of the whole human race in Adam. ${ }^{22}$ But, again alluding to Gen 2:7, the plasma without the adspiratio vitae remains inanimate. The infusion of the breath of life renders the man a "living human" (animavit hominem, Gen 2:7) and a "rational being" (animal rationabile). Rationality is a key component of the imago dei and Irenaeus' view of human freedom. The use here is particularly polemical. Since, in Irenaeus' view, the Ebionites are in the line of Adam and endowed with human freedom and rationality, they willingly choose not to "understand" (intelligere) or consider (contemplantes) the validity of the Incarnation. Their choice, for Irenaeus, has soteriological implications.

\footnotetext{
${ }^{19} \mathrm{AH}$ 5.1.3. Orbe points to a similar idea in Jesus' warning against the yeast of the Pharisees and Sadducees in the Gospels (Matt 16:6,11; Mark 8:15; Luke 12:1), which may also be part of this use of 1 Cor 5:7. He also errantly labels 1 Cor 5:7 as 1 Cor 4:7. Orbe, Teología V.1, 90, 99.

${ }^{20} \mathrm{cf}$. AH 3.23.7. The language non recipientes, referring to the Ebionites, introduces each allusion/echo.

${ }^{21}$ In this case the similar language of neque intelligere volentes quoniam and non contemplantes quoniam links these concepts.

${ }^{22}$ Behr, Asceticism, 38.
} 
His use of the creation imagery in Gen 2:7 serves as validation that human plasma can in fact receive divine unction and he finds Gen 2:7 a clear expression of union of God and man. The Incarnation, thus, is literally a mirror image of the creation with similar imagery and divine activity at work. He argues that the Ebionites do not accept his reading of Luke 1:35, but actually what they reject is the proper connections between the incarnation in Luke 1:35 and Adam's formation in Gen 2:7. While the language of "Holy Spirit" (Spiritus sanctus) in Luke 1:35 is selfevident, he interprets the "Power of the Most High" (Virtus Altissimi) as the "Son of the Most High God and Father of all" (filius Altissimi Dei Patris omnium), thereby distinguishing between the Author of the Incarnation (the Father) and the object of the Incarnation (the Son). ${ }^{23}$ Through the Trinitarian activity expressed in Luke 1:35, the child born of Mary was united with the "ancient substance of Adam's formation" (antiquae substantiae plasmationis Adae), so that, once again, the substance of Adam's formation becomes "living and perfect" (viventem et perfectum) in the person of Christ. ${ }^{24} \mathrm{He}$ describes this new incarnate union between God and man, following the Pauline imagery of 1 Cor 5:7-8, as a "new generation" (novam... generationem). ${ }^{25}$ This new generation of Christ is the "new lump" (véov $\varphi v ́ p \alpha \mu \alpha$ ) of 1 Cor 5:7 that is properly "animated" (animavit) and imparts life to the faithful (1 Cor 15:22). ${ }^{26}$ Irenaeus conflates allusions to 1 Cor 5:7 with the notion of "life" (vita) inherited from Christ in 1 Cor 15:22. All who remain joined to Adam's formation (i.e. the Ebionites) are subject to death, while all that remain faithful to Christ will be made alive. ${ }^{27}$

The tenor of Irenaeus' objection to Ebionite Christology, therefore, is not necessarily their reading of Luke 1:35 (or their rejection of Luke's Gospel altogether i.e. $A H$ 1.26.2), but their lack of a coherent understanding of salvation history and vision for the man formed in Gen 1-2. Irenaeus makes it clear that any dispute over Luke 1:35 (not to mention how this passage interprets Isa 7:14) must also address the apparent economic continuity-evidenced in the Adam-Christ dialectic of 1 Cor 5:7 and 15:22-between the substance of Adam's formation and Christ's Incarnation.

\footnotetext{
${ }^{23}$ For the implicit connections between Luke 1:3 and Isa 7:14 in Irenaeus' exegetical response to the Ebonites see: Orbe, Teología V.1, 93-4.

${ }^{24}$ AH 5.1 .3

${ }^{25}$ AH 5.1.3. cf. Rom 6:6, Eph 4:22, Col 3:9.

${ }^{26}$ AH 5.1.3.

27 cf. Rom 5:12.
} 
This becomes most evident in the closing lines of AH 5.1.3 where, citing Gen 1:26, Irenaeus formulates clear Trinitarian theology of history and economic trajectory of salvation. Irenaeus uses the imagery of Gen 1:26 in connection with his imagery of "hands" (manus) as a Trinitarian analogy depicting the immediacy of God's presence in the formation of Adam (both in the beginning and throughout salvation history). The Son and the Spirit are the "hands of God" (manus Dei) in Gen 1:26 to whom he proclaims, "Let Us make man in our image and likeness" (Faciamus hominem ad imaginem et similitudinem nostram). ${ }^{28}$ Noting the intertextual connections between Gen 1:26 and Luke 1:35, the "hands" imagery in this context is linked to the two-fold mention of the Son and the Spirit in Luke 1:35. These same "Hands" are at work in the Incarnation in Luke 1:35, fashioning Christ in the same pattern as Adam. Through the imagery of hands, the two-fold mention of the "Holy Spirit" ( $\pi v \varepsilon \tilde{v} \mu \alpha$

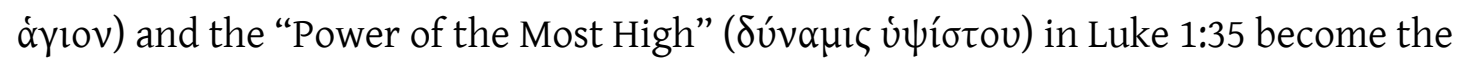
paradigm through which to understand the plural pronoun in the proclamation "Let Us make" (Faciamus) in Gen 1:26. As it was the Spirit and the Power in Luke 1:35, so it is the Spirit and the Word in Gen 1:26. Building upon the imagery of the Hands of God in Gen 1:26, Irenaeus concludes with an allusion to John 1:13, suggesting that the Incarnation is a divine act and not the work of human desire or will. Therefore, Christ cannot be a mere human, but is a "living man" (vivum... hominem, Gen 2:7) born out of the good pleasure of God for the sake of Adam. ${ }^{29}$ When John 1:13 is set in continuity with Gen 2:7, John 1:13 expresses Christ as the ideal man of Genesis. ${ }^{30}$ For Irenaeus, John 1:13 is the natural theological conclusion to the creation of Adam.

While Irenaean scholars generally agree that Irenaeus is relatively inconsistent in his use of imago and similitudo, to date Fantino's study, L' homme. Image de Dieu chez saint Irénée de Lyon continues to be the most comprehensive evaluation of this vocabulary in $A H .^{31}$ Fantino's concludes, by and large, the imago, located in the flesh, refers to the incarnate Son of God, while the likeness refers to the faculty of reason or free will endowed to the creature and the Spirit that conforms the faithful to likeness of Christ's image. ${ }^{32}$ Orbe, commenting on the function of these terms in this section, argues for a Trinitarian reading of these

\footnotetext{
${ }^{28}$ AH 5.1.3

${ }^{29}$ AH 5.1.3; cf. Col 1:19 (Phil 2:13).

${ }^{30}$ Orbe, Teología V.1, 111,

${ }^{31}$ For a comparative chart of all relevant uses see: Ibid.,184-6.

${ }^{32}$ Fantino, L'homme, 128-34.
} 
terms where the image is the Word of God and likeness is the Spirit. ${ }^{33}$ The soteriological function of the Word as the image and the Spirit as the likeness in Gen 1:26 is confirmed when this text is read in continuity with Luke 1:35 and John 1:13 (not to mention the Pauline Adam-Christ typology). Orbe comes close to making this argument when he suggests in passing that pre-incarnate readings of Gen 1:26 (and post-incarnate readings of the Ebionites) did not understand the "scope" (alacance) of Gen 1:26 until the revelation of the Incarnation in Luke 1:35 and John 1:13. ${ }^{34}$ The titles and activity of the divine persons in Luke 1:35 also solidifies the personal distinction between image and likeness. With the revelation of the incarnate Son, the close reader of scripture discovers the Son is the image and the Spirit is the likeness of Gen 1:26. Of course this theological distinction cannot be separated from the anthropological object of salvation. It is the human form that is the locus of the Word and Spirit's activity throughout history. As we can see, Irenaeus does not debate the Valentinian and Ebionites over any particular passage from Gen 1-3, but through a community of texts read alongside these creation texts.

\subsection{AH 5.2.1: Marcion and the Salvation of Another's Property (Gen 1:26)}

Following closely with the previous section, in this chapter Irenaeus counters the Marcionite distinction between the Creator in Genesis and the Father of Jesus. ${ }^{35}$ Irenaeus argues that Marcion believes the supreme God has no association to the material world; it belongs wholly to the Demiurge of Genesis, who is also Yahweh the God of the Jews. ${ }^{36}$ The sensible world and humankind are in every way alien to the Supreme God. This Supreme God, who retains power over the creation sent a Savior to a world that did not belong to him to redeem a people that were not his own. Marcion draws a sharp distinction between the creation of humankind in Genesis and the coming of the Savior in the Gospels.

Irenaeus identifies humankind as God's property by nature, which he reiterates in the opening of $A H$ 5.2.1. ${ }^{37}$ The Father sent the Son, Irenaeus states, to

\footnotetext{
${ }^{33}$ Orbe, Teología V.1, 110-11, 13-15.

${ }^{34}$ Orbe, Teología V.1, 111.

${ }^{35}$ cf. AH 4.18.4.

${ }^{36}$ There is much debate regarding the accuracy of Irenaeus' presentation of Marcion. Orbe, Teología V.1, 121; Harnack, Marcion, 295.

${ }^{37}$ AH 5.1.1. Orbe also suggests alienavit may have origins in Col 1:21 or Psalm 54:7. Teología V.1, 67.
} 
redeem his own creation or property. ${ }^{38}$ According to Tertullian, the language of coming "to another's property" (in aliena) is essential terminology of Marcion drawn from John 1:11. ${ }^{39}$ His polemic in this context focuses on two aspects of Marcion's thought: 1) the unjust nature of redeeming another's property and 2) the ineffectual nature of redemption without blood. ${ }^{40}$ The former addresses the reading of John 1:11, the latter contains echoes of Eph 1:7, and both are set in relationship to Gen 1:26. ${ }^{41}$ First, Irenaeus argues a priori that to steal the property belonging to another is "unjust" (Non... justus). Even if humanity belonged to the Demiurge and is alien (John 1:11) to the true God, it is not right or lawful to steal. Second, redemption that does not involve physical, bodily sacrifice (Eph 1:7) does not redeem the true nature of humanity. Without bodily sacrifice, the Savior did not truly become human and, as a result, humanity remains subject to mortality. Corresponding to the both positions, Irenaeus appeals to the fundamental principle that humankind was made in the image and likeness of God (Gen 1:26). Humankind is not the property of another, but God's very own creation. Not only this, but the Incarnation assumes Christ took possession of his own creation and assumed flesh, thereby effecting the redemption of the people that are "His very own" (suo propria). ${ }^{42}$ At the Incarnation the divine decree of Gen 1:26 comes to fruition and "emerges as an effective reality." 43

\subsection{AH 5.3.2-3: The Power of God the Weakness of the Flesh (Gen 2:7)}

AH 5.3.1 begins a new section in the overall structure of book 5 that addresses the salus carnis. Having worked his way through a critique of the Valentinians, Ebionites and Marcion, Irenaeus now sets his sights on the close evaluation of the Gnostic reading of 2 Cor 12:9. ${ }^{44}$ It is obvious that Irenaeus is familiar with competing Gnostic

\footnotetext{
${ }^{38}$ Although he does not mention Marcion specifically, we know Irenaeus is speaking of Marcion here because of the parallel passage in AH 3.11.2.

${ }^{39}$ Tertullian, Marc. 3.6.2; 3.9.10. See Orbe, Teología V.1, 118; Harnack, Marcion, 266-88. Orbe locates an allusion to John 1:11 in this citation, but it is not noted in SC or BP. Orbe, Teología V.1, 123.

${ }^{40}$ Orbe, Teología V.1, 121.

${ }^{41}$ Rousseau cites this passage as Col. 1:14, but the presence of sanguine here and in Eph 1:7 make the latter the more likely passage in consideration.

${ }^{42}$ AH 5.2.1.

${ }^{43}$ Wingren, Man and the Incarnation, 23.

${ }^{44}$ Orbe notes that Irenaeus comments are not set against any particular heretic (docetists, Marcionites, Gnostics), but against all of them equally. He suggests that he speaks in general terms to include any person who would reject the salus carnis. Orbe, Teología V.1, 167.
} 
interpretations of this passage defending the renunciation of the corrupt body fashion by an incompetent Demiurge. The language of 2 Cor 12:9 orients AH 5.3.15.5.2 and is cited in full in AH 5.3.1. The discussion focuses upon the interpretation of the language of "weakness of the flesh" (infirmitatem... carnis) and the "power of God" (potentiam Dei), extends though AH 5.5.2. ${ }^{45}$ In the hands of Irenaeus, this Pauline text becomes a theological axiom manifesting the power of God over human weakness. This section follows the scheme identified by Bacq. Irenaeus announces the text of 2 Cor 12:7-9 and cites the passage in the opening lines of $A H$ 5.3.1. He then comments on this text through linking terms that unite a series of related texts including: Gen 2:7, 1 Cor 15:53, and Heb 11:19. His argument is framed into two logical claims: 1) God has the power to raise the flesh and 2) the flesh is fit and capable of receiving vivification. Within this rhetorical structure, Gen 2:7 is a key validation for Irenaeus' understanding of the relationship between God's creative power and the resurrection.

Discussing the power of God in 2 Cor 12:9, Irenaeus connects the description of the resurrection and the "power" (virtutem) mentioned in Heb 11:19 and 1 Cor 15:53, with the demonstration of God's creative power in Gen 2:7. ${ }^{46}$ Heb 11:19 describes the "power" (virtutem) God has to raise the dead, while 1Cor 15:53 more explicitly describes the imagery of the power of God to raise the corruptible body to incorruption. ${ }^{47}$ The power made perfect in weakness in 2 Cor 12:9 is the power to raise the flesh expressed in Heb 11:19 and 1 Cor 15:53; therefore, it illustrates the power of God to form and enliven the flesh. What is more, Irenaeus adds that the original creation in Gen 2:7 is even "more difficult and incredible" (multo difficilius et incredibilius) than the resurrection from the dead, because it was creatio ex nihilo. ${ }^{48}$ The resurrection in 1 Cor 15:53 and Heb 11:19 is a mere reassembling of the original form that decomposed into the earth. In the first instance, Irenaeus views the mortality of the flesh as experientially pedagogical, through which humankind becomes aware of the power of God. ${ }^{49}$ He goes so far as to define the weakness of the flesh as being "mortal by nature" (natura mortalis) and there is no hint of humanity's

\footnotetext{
${ }^{45}$ AH 5.3.2. cf. AH 2.34.3-4.

${ }^{46}$ AH 5.3.1 Orbe suggests the background of Eph 1:19-20 and Rom 8:11 (see AH 5.10.2).cf. AH 3.19.9; $A H$ 3.22.1; Orbe, Teología, 1.179.

${ }^{47}$ AH 5.3.1.

${ }^{48}$ AH 5.3.2.

${ }^{49}$ AH 5.3.1.
} 
relationship to $\sin .^{50}$ Mortality is the natural condition of created beings that are, by nature, imperfect. As a result, death is not retributive but a natural consequence of creaturely existence. ${ }^{51}$

Nevertheless, even if God has the power to raise the flesh, Irenaeus reasons that the body must have the aptitude to receive life again. Appealing to the logical analysis of the form fashioned in Gen 2:7, he argues both that God has power to form flesh from the earth and the flesh is capable of receiving the life imparted by God. As a result, this section entertains the contrast between the temporal life in the body and the eternal life given by the Spirit. We have seen how Irenaeus distinguishes between two "modalities of Life" that are separated by degree not nature. ${ }^{52}$ The distinction between the present life and the resurrected life is not a distinction in nature, but a distinction in degree, from a "weaker" or "temporal" life to a "stronger" or "eternal" life..$^{53}$ This reading is borne out of intertextual connections with 2 Cor 12:9. He draws out the imagery of the fashioning of the body in Gen 2:7, including the harmonious binding of the various body parts, such as the sensitivity of the sensory organs and the agility of the muscular system. The aesthetic harmony of the body reveals the "wisdom of God" (sapientia Dei) in creation that is indicative of God's power. Utilizing his rhetorical arsenal he compares the flesh to a sponge or a torch. ${ }^{54}$ Just as the sponge is fit to absorb water and the torch to possess fire, so also is the flesh, as Gen 2:7 testifies, "found fit and capable of receiving the power of God" (Invenietur autem perceptrix et capax caro virtutis Dei). ${ }^{55}$ Just as the body has the capacity to receive the power of God in Gen $2: 7$, so also in the resurrection. ${ }^{56}$

\footnotetext{
${ }^{50}$ AH 5.3.1. Altermath, "The Purpose of the Incarnation," 65.

${ }^{51}$ Brown, "On the necessary imperfection of creation," 21; cf. Orbe, "El hombre ideal en la teología de s. Ireneo," Greg 43 (1967): 449-491, 455.

${ }^{52}$ Behr, Asceticism, 95-6; See AH 2.34.3-4.

${ }^{53}$ Behr, Asceticism, 96.

${ }^{54} \mathrm{AH}$ 5.3.3.

${ }^{55} A H$ 5.3.2. In the following section, $A H$ 5.3.3, Irenaeus develops this argument and suggests the life the Gnostics enjoy now supports the capability of the flesh to participate in life.

${ }^{56}$ This section confirms that Behr and others are right to correct Rousseau on his assertion that "life" in AH 2.34.3-4 is something other than bodily existence. Rousseau, "L'Eternité des peines", 843; $c f$. Donovan, "Alive to the Glory of God," 289.
} 
6.5 AH 5.5.1-2: The Flesh in the Hands of God (Gen 2:7, Gen 2:8, Gen 2:15, Gen

Continuing his discussion of the salus carnis, in AH 5.5.1-2 Irenaeus exploits the longevity of the patriarchs and the nature of paradise as he elucidates, in response to 2 Cor 12:9, the power of God to raise the flesh. Joining his anthropology and eschatology, he describes the economic vision for Adam's formation. God's two Hands, the Son and the Spirit, who form Adam in Gen 2:7, continue to sustain creation throughout salvation history. In Adam, Irenaeus writes, the hands of God became accustomed "to join together, to preserve, to sustain, to bring his form and place him where they pleased" (coaptare et tenere et bajulare suum plasma et ferre et ponere ubi ipsae vellent). ${ }^{57}$ The last three verbs (bajulare, ferre, ponere) are derived from Gen 2:8 (cf. 2:15), where God planted a garden in paradise and placed Adam there for growth and maturity. ${ }^{58}$ The former two verbs (coaptare, tenere) explain the Son and the Spirit's role in holding simultaneously sustaining the bonds and preserving the life of the created form. This characterization of the inter-Trinitarian activity is not, in Irenaeus' view, reserved to Adam's pre-lapsarian life. He has already noted that at no time did the "Hands of God" ever abandon Adam, because the existence and preservation of the flesh depends wholly upon the will and pleasure of God. ${ }^{59}$ Irenaeus joins his citation of Gen 2:8 with an allusion to Adam's expulsion from the Garden in Gen 3:23. While God's will and desire for Adam was the Edenic life, Adam relinquished this opportunity in his disobedience. For Irenaeus, however, following Gen 3 any scriptural account involving the preservation or protraction of the body is explained in relationship to the Hands of God and the nature of paradise including: the translation and assumption of Enoch (Gen 5:24) and Elijah (2 Kings 2:11), the preservation of Jonah in the whale (Jonah 2), and the preservation of Shadrach, Meshach and Abednego in the furnace (Dan 3:19-25). ${ }^{60}$ This also includes the longevity of the patriarchs (i.e. Gen 5:3-32, Gen 9:29) who enjoyed their prolonged life for no other reason than the pleasure and will of God. In each instance the same "Hands" that fashioned Adam and place him in paradise are the

\footnotetext{
${ }^{57}$ AH 5.5.1.

${ }^{58}$ Orbe, Teología V.1, 239.

${ }^{59}$ AH 5.1.3; Orbe, Teología V.1, 225.

${ }^{60}$ AH 5.5.2.
} 
same "Hands" extending and preserving life throughout the unfolding of the divine economy.

While the preservation of the body is reserved for the Hands of God, the experiences of Enoch and Elijah raise the question of the location of paradise. ${ }^{61}$ For Irenaeus paradise is a sensible, intermediate realm separate from the earth, where the just and righteous dwell in anticipation of resurrection and immortality ${ }^{62} \mathrm{He}$ links the experiences of Adam, Enoch, and Elijah, with Paul's rapture to paradise in 2 Cor 12:4. All four are linked through the language of "paradise" (paradisus) in each passage and, in the case of the latter three, the experience of being caught up to heaven. Adam, on the other hand, had existed in heaven and after his disobedience was cast out into this world. ${ }^{63}$ In this sense, Enoch, Elijah and Paul serve to invert Adam's expulsion from paradise in Gen 3:23 and function as a paradigm for "the consummation" (consummationem) where all the faithful will make their way back into paradise to dwell in the presence of God. ${ }^{64}$ Against the Gnostics, their physical bodies are no hindrance to the paradisiacal life.

\subsection{AH 5.6.1: Perfection in the Image and Likeness (Gen 1:26, Gen 2:7)}

Having used the testimonies of the faithful in the Old Testament to communicate the power and providence of God over the preservation of the flesh within the economy, in AH 5.6.1 Irenaeus provides a more focused treatment of the nature the final resurrection in the image and likeness of God. He explicitly links the image of God with the flesh when he states emphatically it is "the flesh that was moulded according to the image of God" (carni quae plasmata secundum imaginem Dei). ${ }^{65}$ Irenaeus also links reason and freedom with the imago dei, but he explicitly rejects any notion of locating the image in the immaterial. ${ }^{66}$ Irenaeus does not come to this conclusion merely from his contemplation on Gen 1:26, a common misunderstanding, but from the intertextual association with Rom 8:29. ${ }^{67}$ Fantino, for example, does not mention Rom 8:29 in his evaluation of this passage and only

\footnotetext{
${ }^{61}$ cf. Epid 10.

${ }^{62}$ Orbe, Teología V.1, 224-3, 240-1; cf. Epid 12.

${ }^{63}$ AH 5.5.1.

${ }^{64}$ AH 5.5.1; Orbe, Teología V.1, 241.

${ }^{65}$ Behr, Asceticism, 89.

${ }^{66}$ Fantino, L' Homme, 87-9; Dem 11; AH 4.37.4.

${ }^{67}$ Holsinger-Friesen, Irenaeus, 109-11.
} 
mentions it elsewhere in passing as a purely eschatological reality. ${ }^{68}$ We have already noted that the bishop is relatively "inconsistent" in his usage of these terms. ${ }^{69}$ When he does distinguish them, the distinction may be understood as "the ontological formation of the human person (image) and the actualization of the human nature in an individual's lived life (likeness)." ${ }^{\text {70 }}$ The former applies most properly to the person of the Son, while the later applies to the activity of the Spirit, but Irenaeus arrives at this rendering of likeness through linking Rom 8:29 and Gen 1:26, which are connected through the language of "image" and the concept of "conformable" (conforme). ${ }^{71}$ Alluding to this Pauline passage, Irenaeus argues that the flesh was created to be conformable (conforme) and adapted (adaptans), by means of the Son and Spirit, to the image of the incarnate Son. ${ }^{72}$ When Irenaeus reads Gen 1:26 in continuity with Rom 8:29, he interprets the notion of being conformed to the likeness as the activity of the Spirit transforming the faithful into the glorified and perfected image of the resurrected Christ. ${ }^{73}$ This transformation is not an instantaneous event but a prolonged plasmatio hominis that extends throughout the course of the divine economy to the final consummation. ${ }^{74}$

The whole person, as Irenaeus will go on to argue, and not merely part of the person, was made in the image and likeness of God. The complete human person is one who is composed of body, soul, and Spirit and the three elements express the participation in the "triune reality" of the Father, Son, and Spirit. ${ }^{75}$ The Gnostics (especially the Valentinians), on the other hand, erect a dualism of human components and partition humanity in three distinctive natures: hylic, psychic, and spiritual. ${ }^{76}$ The psychic human is fashioned after the likeness of the Demiurge, the pneumatic after the likeness of Sophia, and the body of the hylic after the image of

\footnotetext{
${ }^{68}$ Fantino, L'homme, 18, 125-28. For similar uses of Rom 8:29 see AH 4.20.8 and AH 4.37.7.

${ }^{69}$ Steenberg, Irenaeus, 138; Fantino, L'homme, 4-44; Wingren, Man and the Incarnation, 82; Osborn, Irenaeus, 211.

${ }^{70}$ Steenberg, Irenaeus, 138. Fantino suggests that the likeness is "presence of the Spirit," but it seems Behr is right to connect it with the breath of life that is lost in the apostasy. Behr, Anthropology, 115; Fantino, L'homme, 117-8.

${ }^{71}$ AH 5.6.1.

72 Orbe suggest a possible conflation with Phil 3:21 that contains similar imagery and the language of "transform" ( $\mu \varepsilon \tau \alpha \sigma \chi \eta \mu \alpha \tau i ́ \zeta \omega)$, but Irenaeus never mentions this text elsewhere. However, as Orbe also points out, the subject performing the work of transformation is Christ (cf. Phil 3:20).

${ }^{73}$ Fantino, L'homme, 18, 178; Orbe, Teología V.1, 268.

${ }^{74}$ Orbe, Teología V.1, 270.

${ }^{75}$ Steenberg, Irenaeus, 136; Orbe, Teología V.1, 270.

${ }^{76}$ AH 1.5.1-5.
} 
Anthropos. ${ }^{77}$ In essence, Irenaeus argues in Gen 1:26 that God did not say "Let Us make the soul after the image and likeness of God," but God said "Let us make the man after the image and likeness of God". For Irenaeus, the soul and the Spirit are both part of the person, but they do not constitute the "perfect" (perfectus) person.

The perfected human person is not merely body and soul, but also requires the indwelling of the Spirit (1 Cor 2:6). ${ }^{78}$ Irenaeus appeals to the two terms "perfect" (perfectus) and "spiritual" (spiritalis), which he views as synonymous, derived from 1 Cor 2:6 and 2:15 and related to the person formed from the dust and after the image of God in Gen 1:26 and 2:7. ${ }^{79}$ Irenaeus' view, contra the Valentinians, is fundamentally unitary, with the anthropological "commingling and union" (commixtio et adunitio) of the soul receiving Spirit along with the "admixture" (admixtae) of the body fashioned in the image of the incarnate Son (i.e. Gen 1:26, Gen 2:7). ${ }^{80}$ Thus, his anthropological framework is essentially tripartite, consisting of a body and soul that is infused with the Spirit of God. He will often use this philosophical definition of the human person as composed of body and soul. ${ }^{81}$ Irenaeus' reading of 1 Cor 2:11 is consistent with his anthropological framework; the Spirit of a man in 1 Cor 2:11 is the Spirit of God..$^{82}$ But his use of 1 Cor 2:11 implies that the presence of the Spirit alone, without the presence of the body is not a perfect or spiritual person. This is, as Behr notes, Irenaeus' primary point of emphasis when he closes with a citation of 1 Thess $5: 23 .^{83}$

The composite nature of Irenaeus' anthropological discussion from Gen 1:26, Gen 2:7, 1 Cor 2:6,11, and 15 is expressed in toto in the language of 1 Thess 5:23. 1 Thess 5:23 is the crucial tile that unites the anthropological poles of Genesis and

\footnotetext{
${ }^{77}$ Orbe, Teología V.1, 272-3, 283.

${ }^{78}$ Behr, Asceticism, 99-100.

${ }^{79}$ In $A H$ 1.8.3, Irenaeus describes how the Valentinians appeal to 1 Cor 2:14-15, along with 1 Cor 15:46, to explain their three-fold distinction of persons. 1 Cor 15:46 speaks of the "earthly" (choicum) 1 Cor 2:14 speaks of the "animal" (animale) and 1 Cor 2:15 speaks of the "spiritual" (spiritale). Irenaeus has already mentioned that the Valentinians refer to themselves as spiritual and perfect and in the context of $A H$ 1.8.4, he cites the Valentinian use of 1 Cor 2:6 that finds Paul speaking of the mysteries of the Pleroma.

${ }^{80}$ AH 5.6.1; cf. 1 Cor 3:1. He also alludes to 1 Cor $12: 7$ as those who bring to light the mysteries of God.

${ }^{81}$ Behr, Anthropology, 100; cf. AH 2.33.5; Dem 7.

${ }^{82}$ AH 5.6.1

${ }^{83}$ AH 5.6.1; Behr, Anthropology, 100. Behr provides a good discussion of the interpretative difficulties of this passage presented in Rousseau's translation. Rousseau wants to render the homo spiritus, as the human soul, but as Behr notes, Irenaeus never does so. So the Spiritus is the Spiritus Dei as the one who owns and inhabits the human creature. Behr, Anthropology, 99 n. 51. Likewise, Orbe (contra Rousseau) consistently identifies the spiritus hominis with the spiritus Dei. Behr and Orbe are right to observe that in Irenaeus, the spiritus is always divine, comes from God to humankind, and is considered an essential component of the perfect human. Orbe, Teología V.1, 274-5; cf. SC 152.227-32.
} 
Paul. It mentions all the component parts of the human person: body, soul, and Spirit, along with the language of "perfect" (perfectus). ${ }^{84}$ Arguing from 1 Thess 5:23, those who are "perfect" are those who present to the Lord all three parts in concord. Contrary to the breath of life that infuses the formation from the dust, the flesh is vivified and made spiritual by the Spirit. These exegetical relationships communicate the creation of humankind and the eschatological perfection of the human person who is created in the image and likeness of God.

\subsection{AH 5.7.1-2: The Narrative of Resurrection (Gen 2:7, Gen 3:19)}

In AH 5.7.1-2 Irenaeus continues his discussion of Pauline resurrection texts with a discussion of 1 Cor 6:14 and Rom 8:11. ${ }^{85}$ In previous sections, Irenaeus mentioned how the incarnate Christ is the true image of God (Rom 8:29), but the present offers the full development of this thesis where Christ's resurrected and glorified body is paradigmatic for the resurrection of the faithful. ${ }^{86}$ In continuity with Bacq's pattern, Irenaeus announces and cites 1 Cor 6:14 and then discusses this passage through a series of interrelated texts including: Gen 2:7, Gen 3:19, John 20:20, Rom 8:11, Psalm 21:31 LXX, and 1 Cor 15:36,42-44. ${ }^{87}$ In doing so, Irenaeus interprets a Pauline theology of the body as a logical economic conclusion to the anthropology of Gen 2:7 and Gen 3:19.

Irenaeus begins with an allusion to Christ's resurrection appearance in John 20:20 linked with 1 Cor 6:14 and Rom 8:11. Referring to the corruptible nature of the human form in Rom 8:11, he asks the fundamental exegetical question, "What, then, are mortal bodies?" (Quae sunt ergo mortalia corpora). ${ }^{88}$ Paul's language of "mortal bodies," Irenaeus reasons, cannot refer to the soul or the Spirit, because these are naturally immortal. Neither is this a type of Gnosticized "spiritual” body. Instead, turning to Gen 2:7 he argues souls are incorporeal and bodies are corporeal. The flatum vitae that enlivens the man in Gen 2:7 must be, contrary to the mortal body fashioned from the earth, immortal. Logically it also follows that if the flatum vitae is immortal then the soul is immortal also, since Adam became a "living soul" (animam

\footnotetext{
${ }^{84}$ AH 5.6.1; cf. AH 2.33.5.

${ }^{85}$ Rosseau's re-ordering of chapter divisions to include the last lines of $A H$ 5.6.2 as the opening lines of $A H$ 5.7.1 is appropriate, as it corresponds both in content and structure to the rest of AH 5.7.1-2.

${ }^{86}$ Orbe, Teología V.1, 323.

${ }^{87}$ In SC 153:84.78ff. See also: SC 152, 173.

${ }^{88}$ AH 5.7.1; Wingren, Man and the Incarnation, 206 n. 69.
} 
viventem, Gen 2:7).$^{89}$ Irenaeus also finds the incorporeal nature of the soul in the parallel terminology of Psalm 21:31 LXX, "my soul shall live to Him" (anima mea illi vivet), arguing that David speaks as if the soul is immortal and not subject to corruption. For Irenaeus, then, Paul's term "mortal bodies" must refer to the corporal substance fashioned from the dust in Gen 2:7 that receives the flatum vitae from God.

Given this exegetical discussion, Irenaeus discerns two basic principals of the soul in contradistinction to the body: 1) simplicity and 2) effectual life. ${ }^{90}$ While the body is composite and fashioned from various components (i.e. joints, ligaments, etc.), the soul is simple. ${ }^{91}$ The soul cannot decompose or breakdown. Second, the soul is also the effectual life of the body. Without the soul, the body is quite literally inanimate. The body receives the breath of life, or soul, and then becomes a "living soul" (animam viventem, Gen 2:7). As Behr notes, "Irenaeus is not interested so much in the soul itself, as a principle of interiority, as in this animation of the flesh.... The soul does not simply animate the body, but uses the body as an artist uses an instrument." 92 Death does not apply to the soul because the soul is the breath of life, rather in death the body becomes "without breath" (sine spiratione) or "inanimate" (inanimalis) and, according to Gen 3:19, dissolves back into its original substance.

Having established the meaning of mortal bodies, in AH 5.7.2 Irenaeus describes how the "power of God" (virtute... Dei) is able to resurrect the mortal flesh referring back to 1 Cor 6:14. In the previous discussion, Irenaeus concluded that the mortal body of Rom 8:11 is the same body that decomposed back into the earth, but now he must complement this discussion with the eschatological vision of the resurrection of the same mortal body. The allusion to the power of God incites an allusion to 1 Cor 15:43b, which also connects back to the dissolution of the flesh in Gen 3:19. The use of 1 Cor 15:42-44 sets up the eschatological dialectic between the natural body and the spiritual body. The Valentinians, on the other hand, identify the "mortal body" of Rom 8:11 and the "animal body" of 1 Cor 15:44 with the soul, or the psychic element, that is by nature corruptible, mortal, and resuscitable. ${ }^{93}$ The pneumatics, or the spiritual bodies, are altogether of a different quality and nature.

\footnotetext{
${ }^{89}$ Orbe, Teología V.1, 331; cf. AH 2.34.4.

${ }^{90}$ Orbe, Teología V.1, 341.

${ }^{91}$ On the composite nature of the body see $A H$ 5.3.2 and $A H$ 5.6.1-2.

${ }^{92}$ Behr, Asceticism, 96; cf. AH 2.29.3.

${ }^{93}$ Orbe, Teología V.1, 349-50.
} 
For Irenaeus, however, the "natural body" (corpus animale) suffers from "corruption" (corrtpuione), "dishonor" (ignobilitate), and “weakness" (infirmitate). This is the body that is "sown" (seminas) in 1 Cor 15:36, which links with the "earth" (terra) as the substances from which the body was cast (Gen 2:7). ${ }^{94}$ Just as the "moral bodies" of Rom 8:11 are identified as the corporeal body, so also is the seed sown in 1 Cor 15:36 identified with the flesh, not the soul.

The language of "sowing" (semino) and the imagery of the decaying body mentioned in 1 Cor 15:36 and 1 Cor 15:42 are drawn together with several characteristics of the body mentioned in 1 Cor 15:43-44. While Gen 3:19 is set as a backdrop to all these descriptions of the flesh, Irenaeus makes the passage explicit when he remarks the flesh is weak because it is composed of "earth" (terra). The ignoble images of dust and seeds communicate, for Irenaeus, the humility and fragility of the human form. In itself, the flesh does not have the power to overcome its own inherent weakness. ${ }^{95}$ That power, according to Irenaeus, must be supplied by the power of God that resurrects the same animal body that is sown in weakness as a glorified spiritual body (Gen 3:19, 1Cor 15:43-44). ${ }^{96}$ He conflates the decomposition imagery of Gen 3:19 with the first half of 1Cor 15:43a, because, for Irenaeus, the dissolution of the flesh only applies to the "animal body." The glorified body, or spiritual body, that was sown into the earth in Gen 3:19 is raised in power in 1Cor 15:43-44.

\subsection{AH 5.8.1: The Spirit and the Image and Likeness (Gen 1:26)}

Having provided a highly involved exegetical discussion of the resurrection of the flesh, in AH 5.8.1, Irenaeus extends this argument with a closer evaluation of the Spirit's function in the resurrection of the faithful. Irenaeus argues the "pledge" (credentes) of the Spirit, mentioned in Eph 1:14, renders the faithful spiritual even in the present dispensation of the divine economy. ${ }^{97}$ The indwelling of the Spirit occurs in the flesh, not by removing or setting aside the flesh. Thus in a certain sense the mortal is, even in the present, swallowed up by immortality (2Cor 5:4). This point explains Rom 8:9 where Paul argues that the faithful are not in the flesh but in

\footnotetext{
${ }^{94} c f$. John $12: 24$

${ }^{95}$ AH 5.7.2.

${ }^{96} \mathrm{AH}$ 5.7.2.

${ }^{97}$ AH 5.8.1.
} 
the Spirit. Contrary to the Gnostics, being "spiritual" (spiritualis) was not characteristic of select individuals temporarily united to a body and soul, but those who, with body and soul, have received the Spirit. ${ }^{98}$ The faithful who receive the Spirit as a pledge, according to Rom 8:15, are able to cry out "Abba Father" (Abba, Pater) as they groan for their future resurrection when they shall see God face to face 1 Cor 13:12. This argument from the scriptures moves from part to whole; the pledge of the Spirit in the present (Eph 1:14, Rom 8:9,15) is a portion of the "universal grace of the Spirit" (universa Spiritus gratia) that will be the fullness of the Spirit imparted to the faithful by God the Father at the final consummation (Gen 1:26, 1 Cor 13:12). ${ }^{99}$ The pledge is a promise for what the faithful will receive in the resurrection when they are rendered, once again, "in the image and likeness of God" (secundum imaginem et similitudinem Dei). ${ }^{100}$ However, this is not a return to the Edenic state, but a restoration of the similitude to God that finally accomplishes the "perfect will" (perficiet voluntatem) of the Father set forth in the beginning (Gen 1:26). This is one of the few instances where the Spirit, rather than the Son, explicitly accomplishes the fulfillment of Gen 1:26, although the Son must be in view because, for Irenaeus, the Son always executes the will of the Father. ${ }^{101}$ In this case, we also find the Father's will is embodied in Gen 1:26 and is realized when the pledge of the Spirit that leads the faithful incrementally toward perfection, gives way to the fullness of the Spirit that renders them in the image and likeness of God.

\subsection{AH 5.10.1: The Olive Tree and the Image and Likeness (Gen 1:26)}

The section of $A H$ 5.9.1-14.4 concerns the interpretation of 1Cor 15:50 and the enigmatic saying, "Flesh and blood cannot inherit the kingdom of God" (caro et sanguis Dei hereditare non possunt). The Gnostics term this passage "decisive evidence" against any claim for a future bodily resurrection. ${ }^{102}$ Irenaeus' response entails the complex intertextual argumentation where he concludes that flesh and blood, in their present state, cannot inherit the kingdom of God, but must be

\footnotetext{
${ }^{98}$ Orbe, Teología V.1, 380.

${ }^{99} \mathrm{AH}$ 5.8.1. He uses 2 Cor 5:4 to argue implicitly for both positions.

${ }^{100}$ AH 5.8.1.

${ }^{101}$ Orbe, Teología V.1, 376-7.

102 Pagels, The Gnostic Paul: Gnostic Exegesis of the Pauline Letters (Philadelphia: Fortress Press, 1975), 85; cf. AH 5.13.2.
} 
inherited by the Spirit. ${ }^{103}$ The controlling text in this section is the imagery of the wild olive tree in Rom 11:17, which he interprets as the flesh that is engrafted to the Spirit as the good olive tree. Those who are not engrafted with the Spirit are, according to Matt 7:9, cut off and thrown into the fire. These same individuals are fruitless and expose themselves as the tares sown among the wheat in the parable of Matt 13:25. Those engrafted to the good olive tree, on the other hand, "receive the Word of God engrafted" (insertionem accipientes verbum Dei), which ensures their progress toward "the pristine nature of humankind" (pristinam... hominis naturam). Irenaeus describes this "pristine nature" the original formation of Adam in the image and likeness of God (Gen 1:26). This qualification of a "pristine nature" connotes a pre-lapsarian condition of Adam, but also, given the contextual scriptural imagery (Rom 11:17, Matt 7:9, and Matt 13:25), describes the salvific trajectory of the divine economy that tends towards the eschatological perfection of the faithful. The faithful who are, at present, engrafted to the good olive tree of the Spirit will receive the engrafting of the Word that forms them in the image and likeness of God.

\subsection{AH 5.12.1-6: The Breath of Life and the Spirit (Gen 1:26, Gen 2:7)}

Irenaeus' reading of 1 Cor 15:50 contrasts the experiences of life and death, but in AH 5.12.1-6 the Bishop of Lyon clarifies his anthropological perspective. For Irenaeus death and life are ontologically contrasting conditions; they cannot mutually coexist within the same person. The flesh, for its part, remains a bystander that may be drawn in the direction of corruption or incorruption. But Irenaeus must address the reality that, in the present, even those who experience life are still subject to death and corruption. For this reason, he speaks of "life" (vitae) in two senses that distinguish the present life within the divine economy given by the breath of God, which remains subject to death, and the eschatological glorified and incorruptible life in the Spirit. ${ }^{104}$ Each section in AH 5.12-2-4 contains echoes or allusions to Gen 1:26 or Gen 2:7 set in intertextual relationship to other texts

\footnotetext{
${ }^{103}$ Behr, Asceticism, 105

${ }^{104}$ Similar to arguments he has made in $A H$ 5.3.2 and $A H$ 5.7.1-2
} 
including: Isa 25:8, Isa 42:5, Isa 57:16, Acts 2:17, 1 Cor 15:22, 1 Cor 15:45-46, and Gal $1: 15-16 .^{105}$

In the opening paragraph of $A H$ 5.12.1, Irenaeus sets up the contrasting natures of life and death. While death, he reasons, has the power to overtake the human and drive life away, life bestowed by the Spirit must also posses the power to overcome death and restore the human to life with God (Rom 6:11). Irenaeus finds this idea taught in Isa 25:8 where the reality of death's champion over life gives way to the eschatological life of God that swallows up death and wipes away every tear and sorrow. ${ }^{106}$ Commenting on this passage, Irenaeus offers the principal contrast between the temporal life and the eternal life. The former life was given by the breath of God (Gen 2:7), while eternal life is given by the Spirit. This distinction raises the question of the nature and quality of life in both economic stages. If the former life was expelled by death how can the faithful be certain that the eternal life will not be subject to the same influence of mortality? The distinction between the present life and the resurrected life is transition from a weaker imperfect condition of life to a stronger perfected condition of life. ${ }^{107}$ There is no qualitative difference in the temporal life and the eternal life; the difference is the quantitative degree of life. ${ }^{108}$ Both the former life of Adam and the glorified life of Christ are sourced in the Spirit, but Adam was only recently created and the life given by the breath was imperfect and undeveloped. For this reason it was easy for death to overtake the weak portion of the Spirit given to Adam, in contrast to the vigorous life given by the Spirit under the New Covenant cannot be subject to the power of sin and death.

This quantitative distinction of the Spirit, for Irenaeus, establishes an exegetical contrast between the breath of life that animated Adam in Gen 2:7, with the vivifying Spirit in 1 Cor 15:45 that causes the human to become spiritual. The ephemeral life given by the breath to Adam, gives way to the spiritual life bestowed by the Spirit through Christ. Irenaeus' union of Genesis and Paul is confirmed with reference to Isaiah. Citing Isa 42:5, the same God who fashioned the earth also imparted breath to all and the Spirit to those who walk upon the earth. He

\footnotetext{
${ }^{105} c f$. . AH 5.18.1-2.

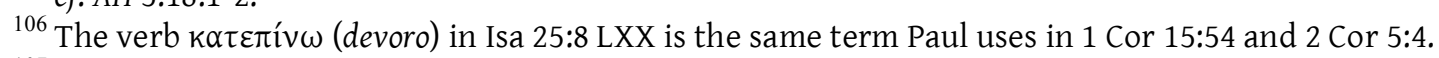

${ }^{107}$ Behr, Asceticism, 95-6; See AH 2.34.3-4; AH 5.3.3.

${ }^{108}$ Orbe, Teología V.1, 532-3.
} 
distinguishes between the collective nature of the breath that is imparted to all people, and the Spirit given only to those "who walk upon it [the earth]" (qui calcant illam). All humanity has inherited the "earth" (terra), that is the substance God uses in Gen 2:7 to fashion Adam, but now only those who have received the Spirit have sufficiently overcome or "tread down their earthly desires" (inculcant terrenas concupiscentias) ${ }^{109}$ Likewise, in Isa 57:16 the breath is "common throughout creation" (communiter in conditione) as a part of the creative work and, therefore, ephemeral and vulnerable. ${ }^{110}$ The Spirit, on the other hand, is consubstantial with God, and proceeds outward from God (Acts 2:17) remaining permanently in its place within the human form. ${ }^{111}$

Continuing the contrast between the breath and the Spirit, Irenaeus applies the Adam-Christ typology of 1 Cor 15:45-6 to reinforce the salvific and economic trajectory of this relationship. He employs Adam and Christ as paradigms for the qualitative distinction between the breath in Gen 2:7 and vivifying Spirit in 1 Cor 15:45. ${ }^{112}$ The breath of life given to Adam (and by extension to all humanity) is provisional and temporary, abandoning the body after death. The Spirit, which follows after the breath, is eternal and permanent. Following the logic of 1 Cor 15:45, the first Adam is animated or rational, while the second Adam is spiritual. Contrary to the Gnostic sensibilities, the spiritual does not precede the rational (humanly speaking); the progression moves from the breath to the Spirit, or the animal to the spiritual. The need for the Spirit was introduced because the one who was made a "living soul" (animam) in Gen 2:7 forfeited his life though disobedience. ${ }^{113}$ Elsewhere Irenaeus has argued in Epid 15 that had Adam and Eve been obedient to God's command they would have remained immortal. As a result the animating breath lost its strength and requires the vivification of the Spirit through adoption. ${ }^{114}$ Those who do not possess the Spirit of God by adoption retain only the breath of life. The distinction turns upon each person's "receptive capacity" for the animating breath of life, which is temporal and mortal, or the

\footnotetext{
${ }^{109}$ AH 5.12.2.

${ }^{110}$ Behr, Asceticism, 105-6.

${ }^{111}$ Orbe, Teología V.1, 541-2.

112 Ibid., 535.

${ }^{113}$ AH 5.12.2.

${ }^{114}$ Behr, Asceticism, 106-7.
} 
vivifying Spirit, that is eternal and immortal. ${ }^{115}$ Behr also reminds us that there are not two sources of life, but one and only one life-giving Spirit who imparts the breath of God in Gen 2:7 and is poured out in fullness upon the faithful (Acts 2:17). Irenaeus' interpretation of the breath of life in Gen 2:7 is only properly understood within the economy of salvation and the vivifying Spirit of 1 Cor 15:45.

In $A H$ 5.12.3-6 Irenaeus bolsters this anthropological argument by establishing the economic continuity and discontinuity between the breath of life in Gen 2:7 and the vivifying Spirit in 1 Cor 15:45. In AH 5.12.3 he notes for the strict continuity in the substance of the flesh that receives life. Although there are two modalities or degrees of life, one temporal and the other eternal, there is only one substance of the flesh partaking of both degrees of life. The same substance that dies and dissolves back into the earth (Gen 3:19) is the same substance that receives the vivifying Spirit (1 Cor 15:45). ${ }^{116}$ Whereas the same lost sheep is the one that is found (Luke 15:4-6), the same body of Christ that experiences corruption is raised to new life in the Spirit. For this reason, just as there is solidarity with Adam in death, so also is there solidarity with Christ in the resurrection (1 Cor 15:22).

This soteriological tension between solidarity with Adam in death and solidarity with Christ in life (1Cor 15:22) is supported by a series of Pauline texts (Col 3:5, Col 3:9-10, and Phil 1:22) and an allusion to Gen 1:26. The transition from one degree of life to the other happens by setting aside not the substance of the flesh, contrary to the Valentinians, but the lusts (concupiscentias) of the flesh ( $\mathrm{Col} \mathrm{3:5).} \mathrm{This}$ is, for Irenaeus, the "old man" (veterem hominem, Col 3:9), or the former way of life (pristinae... conversationis), not the "ancient formation" (veterem... plasationem, Gen 2:7) that was fashioned from the earth, because to live in the flesh is the work of the Spirit (Phil 1:22) ${ }^{117}$ Instead, those who desire solidarity in Christ's resurrection must put on the "new man" (novum hominem) who is being renewed through the true knowledge of God and conformed to the image of the Creator (Col 3:10). Connected through parallel imagery, Irenaeus interprets Paul's reference to the "image of the Creator" (imaginem conditoris) as confirmation of the fulfillment of God's intention

\footnotetext{
${ }^{115}$ Ibid., 107.

${ }^{116}$ AH 5.12.3.

${ }^{117}$ AH 5.12.4. The pejorative use of the Pauline imagery veterem hominem should not be confused with the frequent positive portrayal the antiquam plasmationem that is the physical substance of Adam's body. Orbe, Teología V.1, 87.
} 
for humanity to be made in the image and likeness of God (Gen 1:26) ${ }^{118}$ This new man of Col 3:9 is, for Irenaeus, the recapitulation of the same one created in the beginning to partake of the divine life.

In the closing sections of $A H$ 5.12.5-6, we find two more echoes of the original formation of the flesh in Gen 2:7. Given the soteriological orientation of this section, the substance of the flesh continues to be linking imagery that threads together his arguments and texts. In the same manner as others, Paul was born of a woman (Gal 1:15-16) and received "ancient substance of flesh" (antiqua carnis substantia, Gen 2:7). Later he persecuted the church until he had direct converse with the Lord, then he preached the gospel in the flesh. ${ }^{119}$ In the same manner as the Pauline old man/new man dialectic (Col 3:9-10), the very life of Paul reveals a continuity of substance before and after conversion. ${ }^{120}$

The conversion of Paul is theologically analogous to Christ's miraculous healing accounts in the gospels, because they both exemplify a transition from the temporal life to eternal life in the Spirit. He argues that those who received physical restoration at the hands of Christ, who formed Adam in the beginning (ab initio plasmavit hominem), did so in the same substance of the flesh. The various parts of the body such as the eyes or the hands were not taken from a different substance, but retained the nature of their original form in a healthy condition. However, distinguishing between the particular and the universal, healing the particular members of the body typifies the universal restoration of the whole body in Christ, who confers life upon every portion of the flesh. There is no part or member that does not experience incorruption and life as one integrated whole. Therefore, the same one who created and organized the human form in the beginning is the same one who confers life upon his handiwork in the end.

\subsection{AH 5.14.1-2: The Reconciling Flesh of Christ (Gen 2:7)}

This section brings closure to Irenaeus' extended reflection on 1 Cor 15:50. ${ }^{121}$ While the Valentinians believe this Pauline language obviously refutes a bodily resurrection, Irenaeus builds his case for the salus carnis through a series of

\footnotetext{
${ }^{118}$ AH 5.12.4.

${ }^{119}$ cf. AH 3.12.9.

${ }^{120}$ Orbe, Teología V.1, 586.

${ }^{121}$ Olson, Irenaeus. For the Valentinian reading of 1 Cor 15:50 see Pagels, The Gnostic Paul, 85-86.
} 
intertextual networks (especially Pauline) oriented around the interrelated scriptural imagery that continually draw in Gen 1-3. In AH 5.13.2, Irenaeus divulges what he perceives as the exegetical root of the problem. ${ }^{122}$ According to Irenaeus, the Valentinians interpret the two terms, "flesh" (caro) and "blood" (sanguis), without respect for Paul's intended meaning and neglect to scrutinize the actual force (virtutem) of the terms themselves. Instead, they examine the merely the "terms themselves" (ipsas dictiones), apart from any association the rest of scripture. ${ }^{123}$ As an illustration he compares the Valentinian exegesis of 1Cor 15:50 to an amateur wrestler who, with only single move, latches on to one part (unam partem) of his opponents body. ${ }^{124}$ With a combination of moves, his adversary has no trouble overcoming the inexperienced wrestler. Nevertheless, conquered wrestler continues to maintain his grasp on the one part of his opponent's body and, to the amusement of all the spectators, declare victory. In the same way, the Valentinians refuse to consider the meaning of parallel imagery found throughout the Pauline corpus and ignore the way this imagery participates in the history of salvation. ${ }^{125} \mathrm{By}$ separating terms from their natural Pauline context, they force the apostle into contradiction. ${ }^{126}$ Even the description of the mortal assuming immortality in the immediate context of 1 Cor 15:54 communicates, according to Irenaeus, the salvation of the flesh. As a result, by neglecting the true understanding of one passage (1 Cor 15:50) they misunderstand a multitude of others. ${ }^{127}$

Considering the nature of Irenaeus' exegetical concerns and the tissue of Pauline passages using "flesh" (caro) and "blood" (sanguis) he argues Paul cannot intend to devalue the flesh because elsewhere these terms are essential for defending Christ's human nature and the salvation of flesh. ${ }^{128}$ In both cases, the nature of the flesh in Gen 2:7 occupies a formative role. First, Irenaeus reasons that the blood of the righteous must be required otherwise the Lord would not have spilled blood. From Abel (Gen 4:10), to Noah (Gen 9:5-6), to Christ (Matt 23:35), the blood of the righteous has always been required. These three passages necessitate

\footnotetext{
${ }^{122}$ AH 5.13.2.

${ }^{123}$ AH 5.13.2; Orbe, Teología V.1, 618-9.

${ }^{124}$ AH 5.13.2; cf. AH 5.14.4.

${ }^{125}$ He provides a number of examples throughout AH 5.13.3-4 including: Phil 3:20-21, 2 Cor 5:4, 1 Cor 6:20, 2 Cor 4:10-11, 2 Cor 3:3, Phil 3:10-11, 1 Cor 15:13-21, 32.

${ }^{126}$ AH 5.13.3,5.

${ }^{127}$ AH 5.13.5.

${ }^{128}$ Donovan, One Right Reading?, 150.
} 
that Christ, receiving the same flesh and blood as the original formation of Adam (Gen 2:7), recapitulated the shedding of the righteous blood in his own person and redeemed what was lost in Adam. ${ }^{129}$

Second, against any notion of docetic Christology, Irenaeus argues that flesh requires salvation otherwise the Incarnation would be pointless. Using Gen 2:7 to interpret the language of flesh in 1 Cor 15:50, Irenaeus designates flesh as the very substance created from the dust. If life in the body required a different substance then, Irenaeus reasons, the Father would have moulded Adam from some other substance. However, as Gen 2:7 illustrates, God moulded the man from the dust of the earth and, after he became disobedient, the entire economy of salvation converged upon the advent of the Lord, when he assumed the same flesh and blood. In the words of D'Alès, he was "chair de notre chair."130 In the incarnation he sought out the same substance that has perished (Luke 19:10) and recapitulated in himself the very same flesh and blood, in order to redeem the body of flesh (Col 1:21-22) that was under bondage to sin and bring it into friendship and concord with God. ${ }^{131}$ Wingren expresses this essential connection saying, "Sin is never in itself anything human, but on the contrary is the Devil's destruction of man as God made him."132 Through the rest of the chapter, Irenaeus argues for consistent correlation between the flesh and blood of the first and second Adam through a series of texts. ${ }^{133}$ In the end he concludes, contra the Valentinians, that flesh and blood in 1 Cor 15:50 should not be interpreted properly (non proprie), but metaphorically (and intertextually) as referring to the carnal works of the flesh that deprived humankind of life in the beginning. ${ }^{134}$

\subsection{AH 5:15.2-16.2: Creation, Resurrection and the Healing of the Blind Man}

To this point in Irenaeus intertextual argumentation, we have witnessed a rigorous defense of bodily resurrection from a copious amount of New Testament (especially Pauline) passages. In AH 5.15.1, Irenaeus broadens his approach in order to unify the

\footnotetext{
${ }^{129}$ Orbe, Teología V.1, 661-2; cf. Gen 3:6.

${ }^{130}$ D’ Alès, “La doctrine de la récapitulationen Saint Irénée.” RSR 6 (1916): 185-211, 193.

${ }^{131}$ AH 4.14.2.

${ }^{132}$ Wingren, Man and the Incarnation, 86-87.

${ }^{133}$ He alludes to Rom 6:6, Rom 6:12-13, Rom 6:19, Rom 7:5, 1 Cor 15:50, Eph 1:7, Eph 2:13, 14-15, Col 1:22, Col 2:19, and 1 Pet 2:22.

${ }^{134} \mathrm{AH} 4.14 .4$.
} 
purpose of God, Creator and Father, throughout the divine economy. The resurrection taught in the New Testament is not, as it were, an innovation, but supported by prophetic testimony. ${ }^{135}$ The God of the Old Testament has, according to Irenaeus, repeatedly promised the resurrection from the dead and immortality for the faithful. This intra-testamental focus paves the way for Irenaeus' reflection on a series of three events from Christ's life that epitomize the narrative of salvation. The first of these is an extended commentary spanning AH 5.15.2-16.2 on the healing of the blind man in John 9:1-7 that he reads in continuity with the formation of Adam from the dust in Gen 2:7. ${ }^{136}$ In essence, Irenaeus interprets Jesus miraculous act as a pedagogical illustration revealing the personal interrelationships between the Christ and the creative Word of God and between the Word of God and the Father/Creator. It also confirms the resurrection and immortality for those who are destined for corruption. ${ }^{137}$ As he binds together these poles of the Son's mediating creative activity, he draws together a myriad of passage that support his reading of Genesis and John.

\subsubsection{AH 5.15.2: The Work of God and the Formation of Humanity (Gen 2:7)}

The argument of AH 5.15.2 advocates that John 9:1-7 reveals Christ as the Word of God who mediates the creative purposes of God the Creator and Father. Christ revealed the Creator and Father to humankind, in order to pacify those whom, driven by confusion or madness, might abandon the true God. He does so by showing his disciples that he is the same one who, following the command of his Father, moulded Adam from the dust and breathed into him the breath of life (Gen 2:7). However, not all of Christ's miracles are transmitted in the same manner. There is a distinctive subtlety to this healing account in John 9:1-7 that lies in the mode of communication and the origin of the infirmity. ${ }^{138}$ In most cases, Christ healed by means of a word (sermonem) because this manner of healing is sufficient for all infirmities that derive from $\sin { }^{139}$ He points to the healing of the lame man at

\footnotetext{
${ }^{135}$ Orbe, Teología V.2, 5. In AH 5.15.1 he cites Isa 26:19, Isa 66:13-14,22, Ezek 37:1-10,12-14 and Rom 8:11. ${ }^{136}$ The commentary on the crucifixion comprises $A H$ 5.16.3-20.2, while the temptation account spans AH 5.21.1-24.4.

${ }^{137}$ Orbe, Teología V.2, 24.

${ }^{138}$ Orbe, Teología V.2, 27-8.

${ }^{139}$ AH 5.15.2. Steenberg asserts this section denies the imputation of guilt from one generation to the next, but the language "sin of disobedience" (inobaudientiae peccatum) is singular, while "infirmities" (languores) is plural. This implies some type a relational inheritance between the original
} 
Bethesda where Christ's conversation with the man exposes sin as the origin of his affliction (John 5:1-15). After Jesus tells the man to get up and walk, he implores him to abstain from sin so that nothing worse comes upon him. For those born with physical abnormalities or imperfections, Christ heals by means of a work (operationem). The physical restoration of the body requires the immediacy and labor of the creative Word. ${ }^{140}$ The miracle of John 9 exemplifies the latter case. The poor beggar who was born blind (John 9:1-2) received healing, not by means of a spoken word, but by means of the work of a hand because his deformity was not the result of personal sin. His remedial actions reveal himself to be the same "Hand of God" (manum Dei) forming Adam from the dust in Gen 2:7. ${ }^{141}$

Christ's intent to reveal himself as the Creator in Genesis is, for Irenaeus, evident from the opening query of the disciples. They ask Christ to explain the origin of the man's blindness (John 9:2), to which he responds that personal sin was not the issue (contrary to lame man at Bethesda), but the purpose of his blindness was to manifest in him the "works of God" (opera Dei, John 9:3) ${ }^{142}$ From this key phrase in John 9:3 Irenaeus derives what may be one of his most essential axioms. In a declarative manner, Irenaeus writes: "Now the work of God is the fashioning of humankind" (Opera autem Dei plasmatio est hominis). ${ }^{143}$ Behr calls this statement the "basic structure of Irenaeus' thought." ${ }^{144}$ By all appearances, the "works of God" do not include the works fashioned on the other days of creation, nor does it include angels. ${ }^{145}$ The designation "work(s) of God" is reserved solely for the shaping and forming of human nature. To speak of the "works" (opera) of God in the plural or the singular (opus) makes no difference, because the plural has a collective sense sourced in the singular aspect of God's creative activity. ${ }^{146}$ The foremost demonstration of this theological axiom is, of course, Gen 2:7, which details the "process" (operationem) of God's creative agenda: "And the Lord took dust from the

\footnotetext{
transgressor and the sins committed in subsequent generations, but Irenaeus is not explicit enough to draw any definitive conclusions. Steenberg also points to $A H 4.27 .2-3$ and $A H 4.33 .2$, but there is even less in these sections to support this claim. Steenberg, of God and Man, 46 n. 72.

${ }^{140}$ AH 5.15.2.

${ }^{141}$ AH 5.15.2.

${ }^{142} \mathrm{AH}$ 5.15.2. This point gives more support to Steenberg's thesis on the anthropological focus of creation in Irenaeus.

${ }^{143}$ AH 5.15.2.

${ }^{144}$ Behr, Asceticism, 116.

${ }^{145}$ Orbe, Teología V.2, 37.

${ }^{146}$ For the interchange of the plural opera and the singular opus see AH 4.32.2; Orbe, Teología V.2, 37.
} 
earth and formed man" (Et sumpsit Dominus limum de terra, et plasmavit hominem) ${ }^{147}$ In the same way, when the Jesus chooses to restore the blind man's eyes he repeats the same process of creation: "and the Lord spat on the ground and made clay and smeared it on the blind man's eyes" (Dominus expuit in terram et fecit lutum et superlinivit illud oculis, John 9:6). ${ }^{148}$ The corresponding accounts (Gen 2:7 and John 9:3) are linked through the "earth" (terra) imagery, including "dust" (limum) and "clay" (lutum), the procedural use of the "hand" (manus) and, although he does not make the connection explicit, the moisture of the spittle could match the rain in Gen 2:5 that waters the ground prior to Adam's formation. For Irenaeus, Gen 2:7 forms a functional paradigm for God's anthropological purposes and, though a series of conceptual links, follows this pattern stringently.

The repetition of process also points to the parallel identity of the divine "artist" (artifex) in both accounts. Irenaeus states very clearly that Jesus' intention was to point out his role to the original creation of Adam and manifest the "Hand of God" (manum Dei manifestans) that performed the work of creation. The "hand of God," as we have said, is a common Irenaeus' analogy and, in reference to the hand of Jesus that healed the blind man, serves as a metonym for the person of the Word. This connection between Christ and the Word, as Irenaeus acknowledges, is not purely straightforward. There is some economic discontinuity between Gen 2:7 and John 9:6. In the first account, Adam knew God and held converse with the Word, but the connection between Jesus and the Creator in Gen 2:7 requires faith and "understanding" (intellege). ${ }^{149}$ Irenaeus believes Jesus desires to keep his disciples from seeking after another hand that fashioned Adam (Luke 19:10). He even suggests that the Word of God omitted to form the eyes in the womb, or in secret, so that he could manifest his creative identity in public (John 9:3,6). The public demonstration was a pedagogical and revelatory necessity because, while he formed Adam visibly, he forms all others invisibly in the womb. Only by an outward action could Jesus show that he is the one who both formed Adam and all his posterity. This also indicates that the Word is capable of restoring all other physical abnormalities and redeeming the corrupt human nature that was lost in Adam. The

\footnotetext{
${ }^{147}$ AH 5.15.2. The exchange of Deus for Dominius, reflects the influence of the Gospel account upon his reading of Gen 2:7.

${ }^{148}$ AH 5.15.3.

${ }^{149}$ Orbe, Teología V.2, 41; cf. AH 5.16.2.
} 
particular healing of the blind man becomes its own paradigm for the restoration of humanity in general. Christ came to seek out "lost" (perditos, Luke 19:10). ${ }^{150}$ The lost sheep in Luke 15:4-6 represent humanity crippled by sin, but through his creative powers that span the entire trajectory of the divine economy, Christ is able to hoist the sheep of humanity upon his shoulders and restore it to the fold of life.

\subsubsection{AH 5.15.3: Christ the Creator (Gen 2:7)}

Against his Valentinian opponents, Irenaeus has made every effort to link the creative Word with the person of Christ through the corresponding accounts of Gen 2:7 and John 9:1-7. ${ }^{151}$ Now, in order to seal his argument, he must link the visible Word of God with the Father of Jesus. Without both of these arguments, Irenaeus fails to unify the divine activity in both Testaments. ${ }^{152}$ Continuing his reflection on the fetal development of the blind man in John 9:3, Irenaeus makes the general assertion: "Now the Word of God forms us in the womb" (in ventre plasmat nos Verbum Dei). This in vitro imagery calls to mind the formation of the prophet Jeremiah in the "womb" (vulva) in Jer 1:5 and Apostle Paul's formation in the "womb" (utero) in Gal 1:15. ${ }^{153}$ The one who formed the blind man in the womb (John 9:3) is the same one who formed Jeremiah and Paul in the womb and, when set in continuity, they reveal the identity of the one who formed Adam in the beginning. Throughout the entire divine economy, including the prophets, apostles and all others, the same God forms humankind in the womb. In this line of argument he identifies the healing of the eyes as synecdoche for the formation of the whole person. Even though the Word fashions all humanity from beginning to end, the original decision to form the man was the will of the Father. ${ }^{154}$ The creative activity of the Word was not motivated by an independent agenda, but a direct fulfillment of the command of the Father established in the beginning. ${ }^{155}$

Finally, similar to the function of the Lukan parable of the lost sheep, Irenaeus closes AH 5.15.3 with a reference to the restoration of the body by means of the "washing of regeneration" (lavacro regenerationis, Titus 3:5). Through the

\footnotetext{
${ }^{150}$ This connection is similar to what we found in $A H$ 5.14.2 with the allusion to Luke 19:10, only in the present case he combines this passage with the parable of the lost sheep in Luke 15:4-6.

${ }^{151}$ cf. AH 5.15.4.

${ }^{152}$ Orbe, Teología V.2, 24.

${ }^{153}$ AH 5.15.3; See Jer 1:5 in Epid 43.

${ }^{154}$ AH 5.15.3; cf. Gen 1:26.

${ }^{155}$ AH 5.15.3.
} 
transgression of Adam, his formation had become subject to corruption and mortality (Gen 3:6). ${ }^{156}$ In the context Irenaeus does not mention baptism, but instead simply refers to the Lord's command to the man to go and wash in the pool of Siloam (John 9:7). ${ }^{157}$ While there may be baptismal implications from his connection, what is clear is that the washing serves to restore the man's sight. His sight, moreover, is reflective of his new understanding (cognosceret, $c f$. John 9:37-38). By means of Christ's revelatory act the one who healed his eyes is the same Word of the Father who created Adam from the dust of the earth.

\subsubsection{AH 5.15.4: The Consistency of Creation (Gen 1:26, Gen 2:7, Gen 3:8-9)}

In terms of Valentinian theology, Irenaeus uses the correlation of the healing of the blind man in John 9:1-7 and Gen 1-3 to challenge them on two points. ${ }^{158}$ First, he argues the Valentinians reject Adam's formation from the earth and claim that he was formed from a kind of fluid matter. ${ }^{159}$ If the blind man's eyes were formed from the substance of the earth (John 9:3), but his body from a different substance, Irenaeus reasons, the substance of their eyes would be incompatible with the substance of the body. Logically, Irenaeus asserts, if the eyes of the blind man were formed from the earth (John 9:6), naturally the substance of the flesh is also from the earth (Gen 2:7). Second, the compatibility of substance also points to the consistency of the Creator. It is contradictory if the Savior, who is spiritual, fashioned the eyes in the Gospels, but the Demiurge, who is animal, fashioned the body. For Irenaeus the very same Word of God, who fashioned Adam from the dust of the earth (Gen 2:7), at the Father's command (Gen 1:26), became incarnate in the person of Christ and refashioned the eyes of the blind man (John 9:6).

In a move to explain what he perceives as the second exegetical fallacy, he locates continuity with the divine discourse of the Father proclaiming, "Let Us make" (Faciamus) in Gen 1:26, and he brings to the surface the other analogous dialogical aspects of each account. ${ }^{160}$ Following their disobedience, Adam and Eve were overcome by shame and fear and hid themselves from the presence of the

\footnotetext{
${ }^{156}$ This is a clear echo of Adam's transgression in Gen 3:6, though it is not noted by BP or SC. Orbe, Teología V.2, 58-9.

${ }^{157}$ For a discussion on baptismal regeneration in Irenaeus see Orbe, Teología V.2, 57.

${ }^{158}$ Orbe, Teología V.2, 63.

${ }^{159}$ AH 5.15.4; cf. AH 1.5.5.

${ }^{160}$ AH 5.15.4.
} 
Lord (Gen 3:8). In Gen 3:9 the Lord, walking in Garden in the evening, calls to Adam, "Where are you?" (Ubi es) seeking out his creature that was cowering behind a grove of trees. ${ }^{161}$ According to Irenaeus, the central aspects of the Lord's response of Adam in Gen 3:7-9, sin, concealment, and dialogue, function as prophecies of Christ's actions in John 9 when he healed the man born blind. ${ }^{162}$ Just as Adam and Eve concealed themselves behind the trees in the Garden, so also does the Lord come to people blinded by disobedience. In Irenaeus' view, the work (opera) of the Lord lay hidden and people were unaware of the true Creator. ${ }^{163}$ The healing of the blind man, however, brought to light the work of God (John 9:3,6) and reminded all of God's creative purposes. Irenaeus also parallels the Lord walking in the "evening" (vespere, Gen 3:8), with Christ's incarnation coming in the waning years of history, or the "last times" (novissimis temporibus), to offer salvation. ${ }^{164}$ Finally, just as the Lord, looking for Adam and Eve, called out to them, by means of the same voice (eadem vocem) the Lord call out in search of Adam's posterity. When he conversed with the blind man and restored his sight, Christ revealed himself to be the creative Word of the Father that fashions humanity from beginning to end. ${ }^{165}$ We find in the next paragraph that the Word in Gen 3:9 and John 9 is not speaking on his own, but proclaiming the words of the Father. ${ }^{166}$ Throughout the divine economy, the same Father who commanded the Son and the Spirit to perform the work of creation (Gen 1:26) is conversing with his creatures by means of the Word, drawing them back to the divine likeness. Thus, for Irenaeus, the logical inconsistency in the creative beings of the Valentinian system is a contrast with the uniformity of the creation accounts in Genesis and John.

\subsubsection{AH 5.16.1: Bodies Made of Earth (Gen 1:26, Gen 2:7, Gen 3:19)}

In the previous section Irenaeus proposed two logical inconsistencies in the Valentinian system. The first is the incompatibility of creative substances and the

\footnotetext{
${ }^{161}$ AH 5.15.4.

${ }^{162}$ AH 5.15.4. Irenaeus refers to Gen 3:6-9 as scripture "signifying what would be" (significans quod futurum erat).

${ }^{163} \mathrm{cf}$. AH 5.15.2-3.

${ }^{164}$ AH 5.15.4.

${ }^{165}$ AH 5.15.4. It is not exactly clear which text Irenaeus has in mind when he alludes to Christ's speaking in John 9. The first time Christ speaks to the man is in John 9:7. But Irenaeus could be alluding to the people's questioning of Jesus' whereabouts in John 9:12 as a connection to the questioning of Adam and Eve's whereabouts in Gen 3:9. The other possibility is that Irenaeus is think of the conversation that Jesus has with the blind man after his trial in John 9:35-41.

${ }^{166}$ AH 5.16.1.
} 
second is the inconsistency in creative beings. The latter was taken up in more detail in the preceding discussion, while the former directs the focus of the present section. Now Irenaeus argues from the perspective of Adam's death and, citing Gen $3: 19$, he notes that when humans die their bodies return to the substance of the earth. If bodies return to earth then it is reasonable to conclude they have their substance from the earth. The substance of body that dissolves back into the earth (Gen 3:19) is, therefore, the same substance from which the body was created (Gen 2:7). He reiterates that this same substance Christ used to fashion the blind man's eyes in John 9:6. Therefore, throughout the divine economy, from Genesis to John, the same Word of God, who is always present with his creation, continually fashions humankind from the same substance at the command of the one and same God and Father. Summarizing the anthropological conclusions drawn from the intertextual reading of Gen 2:7 and John 9:6, Irenaeus deduces that their must be only one God who "from the beginning even to the end forms us and prepares us for life, and is present with his handiwork, and perfects it after the image and likeness of God (quae ab initio usque ad finem format nos et coaptat in vitam et adest plasmati suo et perficit illud secundum imaginem et similitudinem Dei)."

\subsubsection{AH 5.16.2: Christ, the Spirit, and the Image and Likeness (Gen 1:26, Gen 2:7)}

In correspondence to the closing allusion to Gen 1:26 in the previous section, Irenaeus transitions to a discussion of the imago dei (AH 5.16.2) and the recapitulatory nature of Christ's passion (AH 5.16.3). Throughout the dispensation of the Old Testament, the faithful knew that humanity was made after the image and likeness of God, but the one made in the image of God had offended God though disobedience. As a result, the true image remained hidden and invisible. ${ }^{168}$ In the first instance, Irenaeus' offers two implications of the revelation of the image of God in Christ. ${ }^{169}$ First, he revealed the true form of the perfect man made in the image of God (Gen 1:26). The Incarnation manifested clearly the fulfillment of God's command in Gen 1:26. God the Father had proclaimed that humankind would be made in the image and likeness of God, but as salvation history began to unravel the

\footnotetext{
${ }^{167}$ AH 5.16.1.

${ }^{168}$ Although he does not make this point explicitly it seems the blindness of the man in John 9 could be part of this argument for the invisibility of the image.

${ }^{169}$ Orbe, Teología V.2, 87.
} 
fulfillment God's original command was not visible until the Word of God, the Image of God, became flesh (John 1:14). The relation of the imago dei to the corporeal flesh has long been recognized, and more than one scholar has rightly suggested that Irenaeus distinguishes between the image and likeness. However, these studies all too often continue to bracket out his anthropology from the rest of his theological and exegetical discussions. ${ }^{170}$ Brunner, for example, distinguishes between the anthropological applications of image and likeness and locates the "image" in human rationality, but neglects the broader theological contours of Irenaeus' thought. Irenaeus' evaluation of the economic harmony of the creation in the image and likeness in Gen 1:26 and with the Incarnation in John 1:14 forms a complex understanding of the Imago Dei. Fantino's extensive study of image of God in Irenaeus remains the most developed study of these terms. Fantino makes the

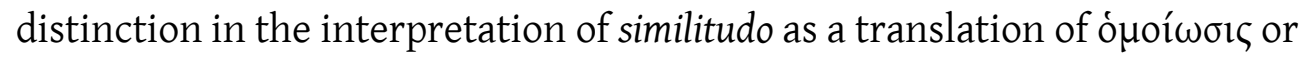
ópoió $\eta \varsigma^{171}$ The former he characterizes as the soteriological work of the Spirit that leads the human person incrementally toward the perfection of the divine likeness. The latter is an anthropological category that comprises the human likeness to God manifested in freedom or rationality. This thesis, however, remains preliminary without original copies of Irenaeus' work. Orbe, on the other hand, published his volume just one year later, offers some penetrating commentary on the interconnections of image and likeness in this section that has received surprisingly little attention, even though his summary is textually and theologically persuasive. He argues that Irenaeus speaks of the Image of God in two senses, the Image (personal) and the Image (substantial). ${ }^{172}$ The distinction is not located in identity but in visibility; that is, the invisibility or visibility of the Image within the timing of the divine economy. The Image (personal), the Word of God, was with the Father at creation and throughout the dispensation of the Old Testament. The Image (substantial) communicates the knowledge of the transcendent Father as visible and sensible. When Adam was created in image and likeness of God he was created by means of the Image (personal), the Word of God the Father, and set on a soteriological trajectory toward the Image (substantial), the Word-incarnate. This is

\footnotetext{
${ }^{170}$ Fantino, L'homme, 83; Donovan, "Alive to the Glory of God," 294. Meijering, searching for elements of neo-platonic background, contrasts this view with Plotinus' understanding of the image of God. Meijering, "God Cosmos History," 262; cf. Steenberg, Irenaeus, 125 n. 82; Minns, Irenaeus, 74.

${ }^{171}$ Fantino, L'homme, 117-8.

${ }^{172}$ Orbe, Teología V.2, 92-3.
} 
what Irenaeus means when he writes that it was "said" (dicebatur) that humankind was created in the image and likeness of God, referring to the divine command in Gen 1:26, but it was not "revealed" (ostendebatur), precisely because the "Word was invisible" (invisibile erat Verbum) in creation and throughout the dispensation of the Old Covenant. ${ }^{173}$ When the Image of God became incarnate (John 1:14), or the Image (substantial), "indeed image was truly revealed" (imaginem enim ostendit verum). The invisible Image of God became the visible and sensible Image of God, assuming the very nature of the creature that was "his own image" (imago ejus). ${ }^{174}$ Of course, the Image (substantial), the resurrected glorified Christ, is also the exemplar of the true Image of God and reflects the destiny of the faithful, who are gradually being assimilated to this Image. ${ }^{175}$ Thus, Irenaeus can speak about the image of God with reference to the flesh because humanity was created in anticipation of the Incarnation, or the Image (substantial) and the future communion of the Word of God with the flesh. In this way the texts of John 1:14 and Gen 1:26 are theologically bound together in his understanding of the imago Dei.

Second, Irenaeus tells us that the Image (substantial) established the likeness. ${ }^{176}$ If the Word is the personal Image of God, then it logically follows that the Likeness is, in some sense, the Spirit of God. ${ }^{177}$ As with the Image, the Likeness, or the Spirit of God, is linked with the physical and corporeal aspect of Adam and essentially functions as the spiritual or divine quality tending the faithful incrementally toward the true Image (substantial). ${ }^{178}$ As a result, the function of the Likeness, or the Spirit, is to assimilate the corporeal nature of humanity to receive the Image of God and prepare the faithful for the new life of the resurrection. Irenaeus reminds us that in paradise, Adam did "easily lose the similitude" (similitudinem facile amisit) after his disobedience (Gen 3:6). Orbe reasons that it was easily lost because the Image (substantial) was invisible; Adam could not comprehend what he would become and was easily dissuaded from this

\footnotetext{
${ }^{173} \mathrm{AH}$ 5.16.2. Note the both dicebatur and ostendebatur are in the singular referring specifically to divine command in Gen 1:26 and the revelation of the incarnation in John 1:14.

${ }^{174}$ AH 5.16.2.

${ }^{175}$ Orbe, Teología V.2, 93-4.

${ }^{176}$ There is debate about the reading of constituit in AH 5.16.2 Rousseau, following the Armenian, replaces and uses restituit instead of constituit. SC 153.217. But I follow Orbe, who prefers constituit, because there is no restoration (restituit) of the likeness until there is installation (constituit) of the Spirit in the person of Christ. Orbe, Teología V.2, 103; See Donovan, One Right Reading?, 161 n. 3.

${ }^{177}$ Minns, Irenaeus, 74.

${ }^{178}$ AH 5.6.1; Orbe, Teología V.2, 94.
} 
eschatological vision. ${ }^{179}$ Then, the image and likeness of God were lost. While the Image of God (substantial) was preparing for the Incarnation, the humankind lost the Spirit qualitatively, but not substantially. ${ }^{180}$ There is a slackening of the Spirit in the loss of likeness, which is no longer able to sustain the human in life. In this case the "likeness" lost in Adam but regained in Christ, is the "strength of the breath of Life" that sustained Adam in his pre-lapsarian state. ${ }^{181}$ We have already evaluated several discussions linking the breath with the Spirit and how the breath, which has come from the Spirit, loses is strength after Adam and Eve's disobedience. It is incapable of sustaining their lives. There is, however, an economic distinction in the "likeness" of God, where the likeness received though the Spirit at Pentecost is the likeness that is qualitatively superior, because it is eternal and lasting.

\subsection{AH 5.16.3: Christ's Passion and Adam's Disobedience (Gen 2:17, Gen 3:6)}

Continuing his efforts to link the work of Christ with the Word of God, in AH 5.16.3 Irenaeus offers a discussion of the passion of Christ in correspondence with the disobedience of Adam. Through his passion, Christ undoes the effects of the disobedience that transpired in the beginning at the "tree" (ligno, Gen 3:6). In contrast to the disobedience of Adam (Gen 3:6), Irenaeus cites Phil 2:8 describing how the second Adam was made obedient unto death. The catchword ligno combines with the asymmetrical relationship of Adam and Christ's actions toward God. The Word of God was clear when he set fourth the command in the Garden not to eat of the tree of knowledge of good and evil (Gen 2:17). Notably, Irenaeus uses the plural inclusive "we offended in Adam" (Adam offendimus), when "he did not perform his commandment" (non facientes ejus praeceptum), implying solidarity and culpability with Adam in his sin. The solidarity is important because, in response, Irenaeus describes how in the second Adam "we are reconciled" (reconciliati sumus, Rom 5:10) to God and made obedient to death. ${ }^{182}$ These comparisons between the first and second Adam, for Irenaeus, extend the economic parallelism between the work of

\footnotetext{
${ }^{179}$ Orbe, Teología V.2, 97-8. If this is the case this need to be synthesized with Irenaeus' view of Adam's pre-lapsarian immaturity. Minns, Irenaeus, 73.

${ }^{180}$ Orbe, Teología V.2, 96-7.

${ }^{181}$ Behr, Asceticism, 114-5.

${ }^{182}$ BP and SC do not mention this allusion, but Orbe identifies the allusion. Orbe, Teología V.2, 115; cf. Rom 5:19.
} 
Christ in the Gospels and the Word of God in Gen 1-3 and solidify the theological coherence of the activity of one God, who is Creator and Father.

\subsection{AH 5.17.1-4: Restoration and Friendship at the Tree}

Locating the economic harmony in the nature of God has been to this point an important part of Irenaeus' flow and argumentation. In AH 5.17.1-2, he continues his reflection on the identity of God with respect to the divine activities in Gen 1-3 and the Gospels. While the Valentinians distinguish the Demiurge from the Father Bythus, Irenaeus finds unity and continuity in the activity of one God and Father throughout both Testaments.

\subsubsection{AH 5.17.1-2: Restoration and Friendship with God (Gen 2:17, Gen 3:8)}

The Son of God, for Irenaeus, is known by many titles. He is the love of the Father, the Lord with power, and the wise Maker and Fashioner. ${ }^{183}$ These names do not reflect, contrary to his Valentinian opponents, different beings, but all of these names speak of the activity of the same divine being working throughout the history of salvation. The combination of the Word as the wise "Maker and Fashioner" (Factor et Plasmator) refers to the general proclamation to make humankind (Gen 1:26) and the gentle forming of Adam from the delicate earth (Gen

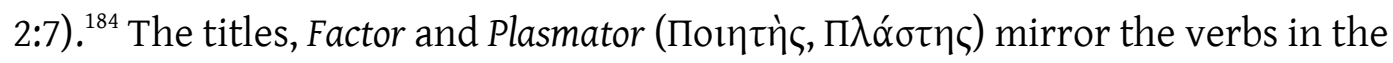

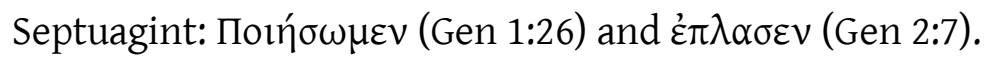

However, this God who designed humankind also established the command to abstain from eating of the tree of knowledge (Gen 2:17). Having transgressed this command in Adam (Gen 3:6), all humanity has become an enemy of the Creator. According to Irenaeus, we know the Word of God gave this command because his presence is perceivable in Gen 3:8: "Adam heard the voice of the Lord God" (Audivit... Adam vocem Domini Dei). The appeal to Gen 3:8, in this instance, seems an odd choice especially since the Lord clearly gives the command in Gen 2:17. Nonetheless, in the bishop's reasoning, the vocem of Gen 3:8 is an analogy for the Verbum of God. ${ }^{185}$ The personal "voice" (vocem) of God is the "Word" (Verbum) of God who manifests the commands of the Father. Referring to the healing of the paralytic

\footnotetext{
${ }^{183}$ AH 5.17.1.

${ }^{184}$ Orbe, Teología V.2, 124.

${ }^{185}$ Orbe, Teología V.2, 142. For similar parallels between vocem and Verbum see Epid. 12 and AH 5.15.4.
} 
in Luke 5:24, he terms Christ the "Voice of God" (Vox Dei), who proclaimed the commands of God (Gen 2:17). In Adam, humanity transgressed the commands and, extending the imagery of Luke 5:24, "paralysis" (paralysis) followed as a consequence of Adam's sin.

For this reason the same incarnate "Word" (Verbum) is able to proclaim the forgiveness of sins in the Gospels (Matt 9:2). ${ }^{186}$ In the incarnation, the Word of God became the mediator between God and humanity (1 Tim 2:5), thereby overturning the disobedience that occurred at the tree. The Word of God, who proclaimed the command of Gen 2:17 and the forgiveness of sins in Matt 9:2, did not speak of his own will, but the will of his Father. He also proceeds to argue conversely that Christ cannot forgive the sins of those he did not create. Forgiveness of Adam's disobedience is only possible if the one proclaiming forgiveness is the same one who established the law of Gen 2:17 and against whom Adam sinned in Gen 3:6.

Irenaeus wants his reader to be clear that this God is not the same Father of whom the Valentinians speak. While the Valentinians distinguish between the Father and the Creator, Irenaeus asserts that in Gen 3:6 Adam sinned against same Father who commanded not to eat of the tree in Gen 2:17. ${ }^{187}$ This is why, Irenaeus concludes, the Lord taught the faithful to pray, "forgive us our debts" (nobis debita nostra, Matt 6:12), because all humankind are the debtors of the Father for transgressing the command of Gen 2:17. ${ }^{188}$ Implicitly he alludes to the Father as the recipient of the prayer (Matt 6:9) in order to unite the activity of the Word of God acting out the will of the Father throughout salvation history. He uses the combination of "propitiating" (propitians) for the faithful and "canceling" (consolatus) the debt of Adam's sin. He also speaks of the true "remission" (remissionem) of sin in the mediation of mercy through the Son (Luke 1:78). ${ }^{189}$ Through the combination of Incarnation and obedience, the incarnate Word of the Father reestablishes communion with the "Creator" (Factorem) that was lost through Adam's disobedience and cancels the debt of Adam's sin.

\footnotetext{
${ }^{186} c f$. Luke 5:20.

${ }^{187}$ Orbe, Teología, V.2, 121.

${ }^{188}$ AH 5.17.1. Osborn suggests that Irenaeus viewed the original sin in terms of "inherited guilt" But Steenberg denies this claim. Osborn, Irenaeus, 218; see also AH 3.18.7 and AH 3.23.2.

${ }^{189}$ AH 5.17.1.
} 


\subsubsection{AH 5.17.3-4: Disobedience and Restoration at the Tree (Gen 3:6)}

The intertextual discussion of Adam's disobedience (Gen 3:6) against the command of God (Gen 2:17) and the activity of the Word incarnate continues in AH 5.17.3-4. As we have seen, the healing of the paralytic and Christ's proclamation of the forgiveness of sins (Luke 5:24, Matt 9:2), alongside the petition for forgiveness of debts in the Lord's prayer, are supported references to the power of the Lord to forgive sins in Psalm 31:1-2 LXX and cancellation of debts that are "assigned to the cross" (addixit illud cruci) in Col 2:14. All of these passages, for Irenaeus, point to the parallels between the disobedience of Adam at the tree in Gen 3:6 and the obedience of Christ upon the tree of the cross. By means of a tree, all were made debtors to God; so also by means of a tree is there forgiveness of sins.

The association of the tree of disobedience with the tree of the cross continues in AH 5.17.4 with a variety of interrelated symbols of the cross. For example, while cutting down trees in the construction of the tabernacle, the disciples of Elisha negligently loose the axe head in the water (2 Kgs 6:1-7). So Elisha threw "wood" (lignum) into the water and the axe head miraculously floated to the surface. He interprets this recovery of the axe head allegorically as the recovery of the Word of God who was "hidden" (absconditum) from humanity at the tree of disobedience and found at the tree of the cross. ${ }^{190}$ Alongside the "wood" (lignum) imagery, he uses the closely related imagery of an "axe" (securis) in Matt 3:10 and Jer 23:29. He also contemplates the four regions of the cross in Eph 3:18, and the extended hands of Christ on the cross as the unification of the two people together under the provision of one God (Eph 4:6). ${ }^{191}$ They are brought together under the "head" (caput) of Christ whose death on the "wood" (lignum) recovers what by means of a tree in Gen 3:6.

\subsection{AH 5.19.1: The Dispensations of Adam and Christ (Gen 3:1-6, Gen 3:8)}

The theological and exegetical harmony between the dispensation of Adam's disobedience (Gen 3:1-6) and the dispensation of Christ persists in AH 5.19.1. The heretics, Irenaeus argues, are ignorant of the integrated nature of these divine

\footnotetext{
${ }^{190}$ AH 5.17.4.

${ }^{191} \mathrm{cf}$. Epid 34. The imagery of the extended hands on the cross is attributed to an elder, which also implies that this intertextual argumentation is partly received.
} 
economies (dispositiones). ${ }^{192}$ In summary fashion, he points to several theological intertextual connections, most of which we have seen elsewhere: the Creator assuming the very flesh he created, Adam's disobedience overturned by Christ's obedience, the Virgin Mary becoming an advocate for the virgin Eve, the sin of the first-created (protoplasti) man undone by the first-begotten (primogeniti), the serpent conquered by a dove (Matt 10:16), and humanity being freed from subjection to death. Together these aspects serve to theologically harmonized dispensations of Adam and Christ. All this imagery of recapitulation points to the loosening of the "bonds" (alligati) that bind humanity to death. Thus, the centerpiece of this interconnection is the crucifixion, where the invisible Word became incarnate for the salvation of the world and was obedient unto death upon a cross. ${ }^{193}$

Of all these recapitulatory relationships, the Eve-Mary typology receives the most attention. Corresponding Eve's actions in paradise with the Annunciation, Irenaeus focuses on the serpent that deceived the "virgin Eve" (virgo Eva, Gen 3:1-5) in contrast to the truth proclaimed by the angel to the virgin Mary (Luke 1:30-35). The former was led astray by the word of an angel and fled from the presence of God (Gen 3:8), but the latter received angelic communication and was obedient. Pointing to the aesthetic coherence between the obedience of Mary and the disobedience of Eve, Irenaeus characterizes Mary as an "advocate" (advocata) for Eve. As we have argued, the Eve-Mary typology serves to complement and illuminate the intricacies of the Adam-Christ typology. ${ }^{194}$

The Eve-Mary typology is not the only theological connection driving the correspondence between the dispensations of Adam and Christ. Echoing the narrative of Gen 3:1-6, Irenaeus correlates the language of serpent in Matt 10:16 to the activity of the serpent in paradise. He casts the "serpent" (serpentis) and the "dove" (columbae) imagery of Matt 10:16 in a recapitulatory relationship where the innocence of the dove overcomes the shrewdness of the serpent. Similarly, the sin of the first-created man (protoplasti, Gen 2:7) was corrected (emendationem) by the punishment (correptionem) of the first-begotten man (primogeniti, Luke 2:7). In this context, we see clearly that, for Irenaeus, the peccatum of Adam in the Garden (Gen 3:6) is the object and basis for the atonement; Christ receives the punishment for

\footnotetext{
${ }^{192}$ AH 5.19.2.

${ }^{193}$ Orbe, Teología V.2, 256; Donovan, One Right Reading?, 157.

${ }^{194}$ Orbe, Teología V.2, 256.
} 
Adam's sin. This action unties (resolutis) the bonds that bound Adam, and his posterity, to death. ${ }^{195}$ Therefore, this mosaic of typological relationships drawn from the imagery of Gen 3:1-6 are all interconnected and realized in the crucifixion of the incarnate Word of God. The same Word, who created Adam, assumed the flesh of his creation and was obedient unto death on the cross in order to correct the sin of Adam's disobedience.

\subsection{AH 5.20.2: Flee to the Church and be Nourished by the Scriptures (Gen 2:8, Gen 2:16, Gen 2:17)}

This section contains a strong polemic where Irenaeus portrays the doctrines of the heretics with the imagery of the blind leading the blind (Matt 15:14) and those who incessantly seek after truth in vain (2 Tim 3:7). They deviate from the true path and wonder down various unmarked roads, with the result that their opinions have no agreement or connection (inconsonanter et inconsequenter). ${ }^{196}$ For the Bishop of Lyon, the church, on the other hand, boasts the collective unity and agreement in doctrine, grounded in the organized economic revelation of the Father, Son and Spirit. He portrays the church with Edenic imagery and compares the seduction of Adam and Eve with the contemporary actions of the heretics. Like Adam and Eve, the faithful are in the midst of the "tree of Gnosis" and must withstand the temptations of their seductive intellectual fruit.

For this reason, Irenaeus implores the faithful to seek refuge in the church to be nourished by the scriptures. The nature of the Garden of Eden prefigures the church, which becomes the manifestation of paradise in the present age. ${ }^{197}$ Orbe points to the possible influence of Matt 15:13, where the unfaithful will be uprooted like trees, which is likely given the reference to the blind leading the blind in the immediate context (Matt 15:14) ${ }^{198}$ While the faithful are planted in the church, the unfaithful will be uprooted and cast out. Elsewhere Irenaeus refers to the church as a vineyard planted in Adam with his sons representing the trees. ${ }^{199}$ This imagery of being "nourished" (enutriri) by the church corresponds to the imagery of "planting"

\footnotetext{
${ }^{195} \mathrm{cf.}$. AH 3.22.4.

${ }^{196}$ AH 5.20.1.

${ }^{197}$ Behr, Asceticism, 66; see also the discussion of the church as the locus of the Spirit in AH 3.24.1.

${ }^{198}$ Orbe, Teología V.2, 328. BP and SC do not recognize this allusion.

${ }^{199}$ AH 4.36.2; Orbe, Parábolas I, 251; cf. AH 5.10.1.
} 
(plantata) Eden in Gen 2:8 and the Lord's command in to eat freely from the Garden, except of the tree of knowledge (Gen 2:16-17). ${ }^{200}$ Irenaeus uses the plural manducabitis, rather than the singular manducabis, which reflects the influence of Eve's recitation of the command in Gen 3:2. ${ }^{201}$ He links the divine command to eat from every tree in Gen 2:16 with the reading of the scriptures, where "every tree" (omni... ligno) becomes "every Scripture" (omni Scriptura) ${ }^{202}$ Within the paradise of the church the faithful are encouraged to partake of every truth found in the scriptures. He also terms them the "Lord's Scriptures" (dominicis Scripturis) in reference to the source of their inspiration and the object of their teaching. ${ }^{203}$ Conversely, the prohibition against eating from the tree of knowledge of good and evil (Gen 2:17, cf. Gen 3:3) is reinterpreted as a command to abstain from the teaching of the heretics. ${ }^{204}$ In the same way, Eve conversed with the tempter, so now the faithful stand before the tree of Gnosis and in the presence of the intellectual temptations of the heretics. He reinterprets the prohibition of Gen 2:17 (Gen 3:3) for the faithful of the church: "but you shall not eat with an elevated understanding nor touching any heretical dissension" (a superelato autem sensu ne manducaveritis neque tetigeritis universam haereticam dissensionem). ${ }^{205}$ The second clause, with the use of tetigeritis, refers Eve's reiteration of the divine command (Gen 2:17) in Gen 3:3. Eve extends the prohibition from not eating, to not even touching (tetigeritis) the fruit. By all appearances, Irenaeus believes Eve reported the command accurately, because he characterizes this conflation of Gen 2:17 and Gen 3:3 as the command of the Spirit of God. ${ }^{206}$ Therefore, the faithful should not merely abstain from partaking of their doctrines, but avoid all contact with the heretics. In addition, the use of superelato ( $\tau \tilde{\eta} \varsigma$ u் $\pi \varepsilon \rho \varphi \rho \circ \eta ́ \sigma \varepsilon \omega \varsigma)$ is taken from Rom 12:3 and reflects Irenaeus' understanding of the mental state of the serpent and the heretics who claim to have "the knowledge of good and evil" (agnitionem... boni et mali, Gen 3:5 and 22) that surpasses the wisdom of the true God.

\footnotetext{
${ }^{200} \mathrm{cf}$. AH 5.5.1. The imagery of nourishment also typically echoes the command of Gen 1:28.

${ }^{201}$ Orbe, Teología V.2, 330-2; SC 152.306. The three variants in the context are all plural (manducabitis, manducate, manducavertitis); cf. Epid 15, AH 5.23.1.

${ }^{202}$ AH 5.20.2.

${ }^{203}$ Orbe, Teología V.2, 327.

${ }^{204}$ cf. AH 5.23.1.

${ }^{205}$ AH 5.20.2.

${ }^{206}$ Orbe, Teología V.2, 333.
} 
Therefore, the prohibition in Gen 2:16-17 (Gen 3:2-3) acknowledges the limits and constrains of human reason. Irenaeus implores his readers to "be wise with prudence" (sapere ad prudentiam, Rom 12:3) in order to keep from duplicating the disobedience of Adam and Eve. ${ }^{207}$ Those who heed the command of God, contrary to Adam, Eve, the serpent, and the heretics, remain securely within the "paradise of life" (paradiso vitae), but those who partake of the doctrines of the heretics will surely be cast out of paradise (Gen 3:23). ${ }^{208}$ Irenaeus depicts the contemporary application of the command of God (Gen 2:17) as the obedience to the preaching of the church understood in terms of the recapitulation, or restoration, the communion of the God and humankind in the person of Christ (Eph 1:10) and through the union with the Spirit. ${ }^{209}$ In the paradise of the church, the life the faithful enjoy though the Spirit is life in flesh and blood and the command is simply a means to manage human immaturity and protect the faithful from repeating the sin of Adam. ${ }^{210}$

\subsection{AH 5.21.1-3: The Temptation of Adam and Christ (Gen 1:26, Gen 2:7, Gen}

\section{3:6, Gen 3:15)}

This section constitutes the third facet of Christ's life that Irenaeus employs to unify the Creator in Gen 1-3 with the Father of Jesus. The first was the healing of the man born blind in John 9:1-7 (AH 5.15-16.2), the second was the crucifixion (AH 16.3-20.2), and the third is the temptation account (AH 5.21-24.4). Each of these aspects of Christ's life are compared and contrasted (Irenaeus prefers the term contrario) to the events of Adam's creation and disobedience in Gen 1-3. ${ }^{211}$ Rather than a chronological correspondence, this three-fold argument follows a logical assertion that links the divine activity in Gen 1-3 with the Incarnation, crucifixion, and final conquering of Satan and his devices. In the context of salvation history, Irenaeus uses the temptation account to show how the Son, who assumed the same flesh as Adam, was faced with the same deceptive tactics and overcame the same enemy that deceived Adam and Eve in the Garden.

\footnotetext{
${ }^{207}$ AH 5.20.2; Steenberg, Irenaeus, 156-7. The use of manducabitis suggests this passage is conflated with Gen 3:2; see AH 5.23.1.

${ }^{208}$ AH 5.20.2; Orbe, Teología V.2, 337. BP and SC do not identify this allusion; cf. AH 3.23.6.

${ }^{209}$ AH 5.20.2.

${ }^{210}$ Steenberg, Irenaeus, 158.

${ }^{211}$ AH 5.18.1; 5.21.3; 5.24.4.
} 
The recapitulation of all things in Christ (Eph 1:10), Irenaeus reports, also includes the recapitulation of the devices of the enemy who conquered Adam. From the opening scene there is an explicit reference to the protoevangelium in Gen 3:15 that orients this entire section. His interpretation of Gen 3:15 envisions the work of Christ provoking the enemy, who had conquered Adam in Genesis (Gen 3:6), and crushing his head. ${ }^{212}$ Ever since God made the proclamation to the serpent in Gen 3:15, Irenaeus reasons, humankind had been diligently anticipating the birth of a man from a virgin, which he also understands as being born in the flesh in the likeness of Adam. For Irenaeus, similitude between Adam and Christ denotes that the virginity of the woman was implicit in the conquering of Satan, because elsewhere he describes how Adam is fashioned from the "virgin" earth (Gen 2:5). ${ }^{213}$ For the Bishop of Lyon, however, the prophecy of Gen 3:15 is mediated by the corresponding references to semen mulieris in Gal 3:19 and Gal 4:4. ${ }^{214}$ The fundamental problem is the injustice that infected the fabric of the divine economy through the deceit of the serpent who has gained victory over humanity. ${ }^{215}$ Satan has not, to be sure, triumphed over God, but over God's creatures. In Irenaeus' reasoning the complex economic design reflected in the correspondence of Genesis and Galatians, was necessary in order to eradicate the injustice of Satan. Since the injustice was committed against Adam, only a descendant born in the likeness of Adam could rightly gain victory over the enemy. Conversely, a mere man born naturally into the captivity has no recourse to vanquish the enemy. Furthermore, since Adam's disobedience was mediated by way of Eve, because it was Eve who ate of the tree first and then Adam in Gen 3:6, the victory in Christ was also mediated by a woman from whom Christ received the same plasma of the original formation. ${ }^{216}$ The synthesis of these Pauline texts with Gen 3:15 implies, for Irenaeus, in the fullness of time, that the one born of a woman is the Son of God made man, thereby fulfilling the prophecy of Gen 3:15 and preparing the way for humankind's victory over death and reception of new life in Christ. ${ }^{217}$

\footnotetext{
${ }^{212} \mathrm{AH}$ 5.21.1. He also alludes to God directing his punishment to the serpent in Gen 3:14.

${ }^{213}$ AH 3.21.10.

${ }^{214} \mathrm{AH}$ 5.21.1. In $A H$ 3.23.7 he appeals to Gal 3:19 and in $A H 4.40 .3$ he alludes to Gal 4:4; cf. Wis 2:24, John 8:44, 2 Cor 11:3, and Rev 12:9.

${ }^{215}$ Orbe, Teología V.2, 358-9.

${ }^{216} \mathrm{BP}$ identifies an allusion to Gen 2:22, but the reference is directed at the formation of Adam in Gen 2:7 and the mediation of Adam's disobedience by way of Eve in Gen 3:6.

${ }^{217}$ AH 5.21.1.
} 
As we have seen previously, what concerns Irenaeus' exegesis is the interrelation (or antithesis) of the actions of Adam and Christ as a means to unify the activity of one God and Father throughout the divine economy. In AH 5.21.2-3 he offers a careful evaluation of the Lord's temptation in Matthew's Gospel in correspondence to Adam's disobedience. The Adam-Christ economic ties bind, contra the Gnostics, the Creator of Adam with the Father of Jesus. The former received the careful touches of the Creator in the beginning, but faltered by means of deception, while the latter, being born of a woman, performed the commands of the Creator and perfected humanity in the image and likeness of God (Gen 1:26). Here we see the fulfillment of Gen 3:15 (through Gal 3:19, 4:4) is ultimately the fulfillment of divine mandate in Gen 1:26. The triumph over the enemy though the obedience of Christ restored the plan of God for humankind to be made in the image and likeness of God.

When the Son of God the Father, therefore, experienced temptation at the hands of the same enemy, the result was altogether contrary to the disobedience of Adam. When tempted in Matt 4:2-10, Christ made use of the Law as a means to thwart the very schemes the enemy used to conquer Adam (Gen 2:16) and expose the identity of the apostate angel who was hidden in the serpent. ${ }^{218}$ Irenaeus reports that Christ fasted before he was tempted (Matt 4:2) in order to reveal his true humanity that is continuous with Adam's formation and to provoke Satan to a duel. Examining their corresponding actions following the temporal references (in principio... in fine), Orbe locates four parallel aspects of each temptation narrative: 1 ) Whereas Adam was prohibited to eat by means of the Law (Gen 2:16), Satan commanded Christ to eat (Matt 4:3); 2) Adam was without hunger (Gen 2:16), while Christ had fasted for forty days (Gen 4:2); 3) While there is deceit in paradise because the enemy remained hidden in the serpent (Gen 3:1-5), Christ exposed the identity of the tempter as Satan himself (Matt 4:10); 4) Adam ate of the tree through the persuasion of the serpent and against the command of God, while Christ withstood the persuasion of the same enemy and, following the commands of God, did not eat. ${ }^{219}$ Therefore, throughout $A H$ 5.21.2, Irenaeus rehearses Christ's three

\footnotetext{
${ }^{218}$ Epid 16. Neither BP nor SC identify references to Gen 2:16 in this context, but the comparisons of the use of the Law with Adam's disobedience to the Law (Gen 2:16) are unmistakable.

${ }^{219}$ Orbe, Teología V.2, 380. Irenaeus also compares Satan's deceptive use of Scripture with the heretics; AH 5.21.2.
} 
temptations (Matt 4:3, 6, 8), and in $A H$ 5.23.3 he develops the connections between the Law of the Creator (Gen 2:17) and the Law of Father that was proclaimed in Christ.

In addition to Orbe's summary, Irenaeus also mentions other dissimilar facets of these events including: 1) Adam as the victim and Christ as victorious, 2) death generated in Adam and life instituted in Christ, 3) Satan empowered through Adam's sin and confounded in Christ obedience, 4) and Satan acting prideful while Christ remained humble. ${ }^{220}$ These must be held in tension with the implicit parallel aspects of these events bound by a series of typological relationships linked by parallel imagery, such as the premise of Satan tempting humankind, the common generations of Adam and Christ, the use of food, and the presence of divine Law. All this continuity and discontinuity, for Irenaeus, is set in relief with the economic progress of salvation history. Through his recourse to the Law, the Savior has overthrown Satan by storming the house of the strong man Christ's obedience and recitation of the Law conquered Satan and spoiled his goods (Matt 12:29), thereby fulfilling the promise of the Creator in Gen 3:15. ${ }^{221}$

\subsection{AH 5.23.1-2: The Day Adam Died (Gen 1:5, Gen 2:16-17, Gen 3:1-5)}

From the preceding sections, it is evident that Irenaeus is concerned with the proper intertextual reading of the creation accounts. In the closing chapters of $A H 5$, the recapitulation of the events in Gen 1-3 takes center stage. In the present context he addresses the truthfulness of the Demiurge. For the Gnostics, especially the Valentinians and Ophites, the serpent is an instrument of Sophia who compassionately leads Adam and Eve away from the trickery of the Demiurge. They point out that though the Creator said Adam and Eve would die in the day they ate the fruit, they did not die. The prohibition of Gen 2:16-17 is nothing more than an empty threat to intimidate the first couple into submission. Therefore, the serpent was truthful and the Creator deceived Adam and Eve. ${ }^{222}$

Irenaeus' rebuttal comprises a complex assortment of no less than five plausible interpretations of Gen 2:16-17 that prove God is true and the serpent is a liar, because Adam and Eve truly died the day they ate of the fruit. Following an

\footnotetext{
${ }^{220}$ AH 5.21.1-2.

${ }^{221}$ AH 5.21.2; Wingren, Man and the Incarnation, 12, 119; cf. Epid 8.

${ }^{222}$ Orbe, Teología V.2, 472-4, 480; Donovan, One Right Reading?, 159-60; cf. AH 1.30.7.
} 
allusion to John 8:44 in the closing lines of AH 5.22.2, he commences AH 5.23.1 with a citation of Gen 2:16-17, which appears to follow Bacq's scheme. ${ }^{223}$ He points to the serpent's subtle perversion of the Lord's command in Gen 3:1-5. In Irenaeus' reading, the serpent's query is his first act of deception, because he knowingly and maliciously construes the Lord's command. ${ }^{224}$ He accentuates the prohibition against the tree of knowledge and insinuates that God's command is overtly authoritarian. Eve, according to Irenaeus, exposed the deceit of his assumption simply by reporting the full version of God's command, which the serpent had omitted, and explaining that God permitted them to eat from every tree, except one (Gen 3:2-3). The serpent persisted in his deceit, even in the midst of the paradise of God, as if the omniscient God was unaware of his malevolent assertions. Irenaeus assumes that Satan was jealous of Adam and Eve and ignorant of the "greatness" (magnitudinem) of God. ${ }^{225}$ This assumption is also reflected in what Irenaeus identifies as the serpent's second lie; the enticement of becoming as gods and endowed with the knowledge of good and evil (Gen 3:4-5). Unaware of the serpent's true intent and the deception hidden in his words, Eve was deceived when the serpent openly challenged the consequences of the Lord's command. Irenaeus isolates Gen 3:4 and inverts the order of the serpent's dialogue, in order to accentuate what Irenaeus identifies as the third and ultimate lie: Adam and Eve would not die if they ate from the prohibited tree of knowledge (Gen 3:4). For Irenaeus, this is a direct assault on the nature and integrity of God. The Bishop of Lyon takes up the interpretation of Gen 3:4 in careful detail in AH 5.23.2. What is clear, for Irenaeus, is that the theological control on his reading of Gen 3:4 is the nature of God in distinction to the nature of the serpent. God is true, while the serpent is a liar (John 8:44). ${ }^{226}$ The fact that they eventually died proves that God was speaking the truth. ${ }^{227}$

The problem remains, however, that Adam and Eve did not immediately die, but lived prolonged lives. ${ }^{228}$ Thus, the Gnostics portray Gen 2:16-17 as the empty

\footnotetext{
${ }^{223}$ The passage itself may be framed in three segments: the command to eat of every tree (Gen 2:17a), the prohibition to abstain from the tree of knowledge of good and evil (Gen 2:17b), and the consequence that the day they eat from the forbidden tree they will die (Gen 2:17c).

${ }^{224}$ Steenberg, Irenaeus, 172.

${ }^{225}$ Orbe, Teología V.2, 472.

${ }^{226}$ AH 5.23.1. Orbe also suggests the background of Rom 3:4. Orbe, Teología V.2, 478.

${ }^{227}$ AH 5.23.1.

${ }^{228} \mathrm{cf}$. Gen 5:5.
} 
threat of a lesser deity. Throughout the course of $A H$ 5.23.2, Irenaeus outlines five aspects of the Gen 2:17 (Gen 3:4). ${ }^{229}$ The first two deal with the relationship of disobedience and death and the legal nature of the consequence, while the latter three are successive attempts to interpret the timing of Adam's sin and death in relation to the meaning of "day" (dies). These interpretations are interrelated, and the distinctions between them depend largely upon the intertexts Irenaeus reads alongside Gen 2:17 (Gen 3:4).

First, Irenaeus interprets the passage straightforwardly; they died the moment they sinned because they were handed over to the power of death. The eventual outcome of Adam's death (Gen 5:5) proves the veracity of the threat. For Irenaeus, the Gnostics misplace their emphasis on the prohibition and the nature of the tree of knowledge, rather than the nature of true Creator. Death does not necessarily imply immediate bodily death, but rather that Adam's disobedience and subjection to the corruptive power of death. To be disobedient to God is death. Orbe observes that Irenaeus, unlike his contemporaries, does not distinguish between bodily and moral or spiritual death, but between physical death and the ultimate death of the composite human person as result of $\sin ^{230}$ They are corruptible and excluded from the kingdom of God with no hope for the incorruptible life.

Extending the effects of Adam's disobedience, Steenberg reflects upon Irenaeus' language, "For along with the fruit they did also fall under the power of death" (Simul enim cum esca et mortem asciverunt) and infers that the "fruit," representative of the "potential for genuine knowledge of good and evil," along with (cum) Adam and Eve are also subject to the effects of their disobedience. ${ }^{231}$ Not only are Adam and Eve personally subject to death, but also there is a comprehensive disruption of the potential for growth and maturity within the divine economy. While his position is certainly interesting, Irenaeus is not describing the cosmic effect of sin, but simply referring to the location of Adam and Eve with respect to the fruit at the moment they suffered death. ${ }^{232}$ At the same moment Adam and Eve were together with (cum) the fruit, they did die.

\footnotetext{
${ }^{229}$ Orbe, Teología V.2, 480; cf. Orbe, "Cinco exégesis."

${ }^{230}$ Orbe, Antropologia, 450-57; AH 4.37-39; Donovan, One Right Reading?, 159-60.

${ }^{231}$ Steenberg, Irenaeus, 167.

${ }^{232}$ Orbe recognizes the fruit is the vehicle or instrument for death. In addition, given the importance of the temporal nature, this could be an ablative of time. Orbe, Teología V.2, 478, 480.
} 
Second, Irenaeus employs legal imagery to interpret the consequence of Adam and Eve's disobedience; through their disobedience they became lawfully beholden to death. This interpretation is closely related to the first (evidenced in the linking phrase propter hoc) interpretation that contemplates the nature of God. ${ }^{233}$ The moment they transgressed the law of God, they were condemned by divine law to die and, as a consequence, became "death's debtors" (debitores mortis). ${ }^{234}$

Third, following his explanation of the nature of death and its consequences, he offers three justifications for the timing of Adam's death with respect to the "day" (dies) he sinned. Even though Irenaeus distinguishes between subjection to the penalty of death and the ultimate bodily death as a means to understand the delay in Adam's death, he must explain how the final death transpired on the same day as the disobedience. He observes that in Gen 1:5 a day of creation comprises evening and morning. In this instance he translates the text as "one day" (dies unus) rather than the "first day" (dies prima). This interpretation understands "day" (dies) from a cosmic perspective, where the "day of creation" (conditionis dies) is one cosmic day. ${ }^{235}$ Generally speaking, this is similar to Philo who points to the Septuagint use of $\mu$ í $\alpha$ rather than $\pi \rho \circ \tau \omega \varsigma$. However, Philo understands this as the intelligible world of Platonic ideas, but for Irenaeus this is the eternal day of the sensible and material world of creation. ${ }^{236}$ As a creature of God, Adam lived and died within the natural course of created existence and, therefore, he was disobedient and subject to death on the same universal day of creation.

Steenberg misses Irenaeus' use of Gen 1:5 in this context and conflates Irenaeus' first and second attempt to interpret "day" in Gen 2:16-7. According to Steenberg, a "day" of creation, reflected in Gen 1:5, implies "God's creative activity began at a specific moment... and progressed in a series of distinct stages defined as 'days." ${ }^{237}$ These days, according to Steenberg, are predictive for Irenaeus of the phases in the economy of salvation reflected in his chiliastic vision. While there is no doubt that Irenaeus presents a chiliastic vision of the economy, Orbe is correct to distinguish Irenaeus' first interpretation of the magna dies of creation that perceives the existence of all creation as "one day." This is clear in Irenaeus' transition from

\footnotetext{
${ }^{233}$ AH 5.23.2.

${ }^{234}$ AH 5.23.2; cf. AH 3.19.1; AH 4.22.1.

${ }^{235}$ Orbe, Teología V.2, 481-3.

${ }^{236}$ Philo, Opif, 15.

${ }^{237}$ Steenberg, Irenaeus, 85-6.
} 
speaking about the (or The) "one day" (dies unus) in terms of cardinal numbers in his first interpretation to contemplating the succession of days as ordinal numbers (prima... secundum... tertia...). ${ }^{238}$ Steenberg's point applies to Irenaeus' second interpretation of "day" (dies) mentioned below, not his uses of Gen 1:5.

Fourth, in continuity with the framework of Irenaeus' doctrine of recapitulation (Eph 1:10), the Bishop of Lyon correlates the timing of Christ's death with both days of Adam's disobedience and death. This interpretation assumes the literal or normative sense of "day" (dies), as simply a one day within the weekly cycle of days. Here Irenaeus departs from the Septuagint reading with cardinal

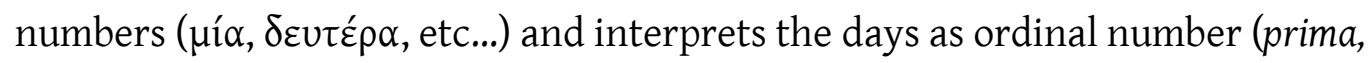
secunda, etc...) as the are arranged in Gen 1. In Irenaeus' reasoning, since Christ died on Friday, or the sixth day (sexta... dies) of the week, logically it follows that Adam died on a Friday ${ }^{239}$ Furthermore, given that the formation of Adam and his disobedience transpired on the sixth day of creation (Gen 1:24-31), Irenaeus deduces that Adam died on the same day, that is the sixth day of the week (or Friday), the very same day of the week that Adam ate of the forbidden tree in Gen 3:6. This explains why Christ died on the sixth day of the week, since it was the same day that Adam sinned.

Since the day of Adam's death is not mentioned (Gen 5:5), Irenaeus solidifies the correspondence between Adam and Christ by extending the recapitulative framework. He links Adam and Christ chronologically in order to suggest Christ has recapitulated in himself Adam and all his posterity who have suffered the effects of death. He also stresses that Adam's death occurred though disobedience to the Father's command, while Christ's death occurred though obedience to the same Father. Finally, having determined though his recapitulative logic that Adam died on the sixth day of the week, he deduces that Adam's formation from the substance of the earth (Gen 2:7) and Adam's death occurred on the same day. The corresponding death of Christ on the same day in the same substance of the flesh produces a "second creation" (secundam plasmationem) by means of death. ${ }^{240}$

\footnotetext{
${ }^{238}$ AH 5.23.2.

${ }^{239}$ AH 5.23.2.

${ }^{240} \mathrm{AH}$ 5.23.2. Irenaeus does not refer to the resurrection, which, of course, did not occur on the same day; see Orbe, Teología V.2, 491-2.
} 
Finally, Irenaeus interprets the "day" (dies) of Adam's death from the perspective of the chiliastic vision of the economy. Following 2 Pet 3:8 (Psalm 89:4), Irenaeus draws on the equation that a day of the Lord equals 1000 years. ${ }^{241}$ Adam did not live beyond 1000 years and, therefore, he ate of the fruit and died on the same day of the Lord. ${ }^{242}$

In the closing lines Irenaeus summarizes these views in succession. ${ }^{243}$ Depending upon the context, Irenaeus can read Gen 2:17 in light of Gen 1:5, Gen 1:24-31, Eph 1:10, 2 Pet 3:8 (Psalm 89:4 LXX), and other implied references mentioned above. Irenaeus is unconcerned with the assortment of interpretations and he does not care to defend one perspective over the others. ${ }^{244}$ On the contrary, multiple interpretive vantage points actually strengthen his theological perspective because all prove the truth of the apostle's words; God is true and Satan is a liar (John 8:44). ${ }^{245}$ For Irenaeus, the reason the Gnostic interpretations are rejected is simply because they subvert this basic apostolic truth and make the Creator out to be a liar.

\subsection{AH 5.26.2: Blasphemy Against the Creator (Gen 3:1-6)}

As in previous sections, here we find another echo of the disobedience of Adam and Eve in Gen 3:1-6. While explaining some of the eschatological prophecies from Revelation and Daniel, he breaks off his discussion and inserts a polemical argument concerning prophecy. According to Irenaeus, those who reject the clear teaching of the prophets blaspheme their Creator. They may do so openly like Marcion or by perverting scripture like the Valentinians, but whatever the case may be they are all, just like the serpent in the Garden, the "instruments of Satan" (organa Satanae) ${ }^{246}$ Irenaeus interprets Satan's use of the snake as a means to conceal himself from God's awareness and seduce Adam and Eve into disobeying God's

\footnotetext{
${ }^{241}$ cf. AH 5.28.3.

${ }^{242}$ While he accepts its legitimacy, it is not altogether certain that Irenaeus prefers this view because he qualifies it, contrary to the previous positions, as the perspective of others (Quidam autem...). Nevertheless, Steenberg and Smith affirm it as a key Irenaeus position in their discussions of Irenaeus' Chiliasm. Orbe, Teología V.2, 493. Orbe suggests this is from Justin; cf. Dial, 81.3; Steenberg, Irenaeus, 84-86; cf. Smith, "Chiliasm," 16-18.

${ }^{243}$ AH 5.21.2.

${ }^{244}$ Orbe, Teología V.2, 500.

${ }^{245}$ He clearly accommodates the Pauline saying that God is true and all men are liars (Rom 3:4), applying the latter portion to the nature of the serpent. Orbe, Teología V.2, 478. Both BP and SC omit this allusion, but as Orbe shows the parallel language is unmistakable.

${ }^{246}$ AH 5.26.2; cf. 2 Cor 11:3; Rev 12:9, 15.
} 
command. He would never challenge God directly or openly. This same secretive and deceptive behavior continued throughout the course of the Old Testament, and all along Satan believes his actions escaped the knowledge of God. Appealing explicitly to Justin, Irenaeus argues that the reason Satan continued to deceive God's creatures in secret was because he was unaware of his fate. It was only prophesied enigmatically in the Old Testament. ${ }^{247}$ The words of Christ, however, made explicit that God the Father has prepared an eternal fire for Satan and his agents (Matt 25:41). ${ }^{248}$ So while Satan never blasphemed God openly, upon learning his fate, he now openly (though not directly) blasphemed God. ${ }^{249}$

\subsection{AH 5.28.3-4: Irenaeus' Chiliastic Vision (Gen 1:26, Gen 2:1-2, Gen 2:7)}

The chiliastic focus of AH 5.25-35 has long baffled Irenaean scholars. This closing portion is often ignored, ridiculed or, as Steenberg remarks, simply set off as a kind of “chiliastic appendage.” ${ }^{250}$ However, Smith's in his essay “Chiliasm and recapitulation" argues that this section has an important relationship to the broader contours of Irenaeus' thought. Smith argued that this last portion completes the "essential harmony of the true soteriological task," thereby linking the protological and eschatological events of creation. ${ }^{251}$ We find much agreement with Smith and Steenberg and our study of the intertextual use of Gen 1-3 supports the renewed appreciation for the full re-unification of Irenaeus' thought and exegesis.

The function of Gen 1-3 serves as the essential framework by which Irenaeus makes sense of the eschatological Edenic state. Not only does the chiliastic portion reflect the telos of the eschatological advancement from creation to the eternal kingdom, it holds together the poles of the scriptural material by means of the trajectory of the divine economy. This eschatological kingdom is not a pure mystical

\footnotetext{
${ }^{247}$ cf. Gen 3:14; $A H$ 3.23.3. This thought is only implicit in Justin's extant works ( 1 Apol. 28.1-2; 2 Apol 8.3-5); Orbe suggests the source as his lost refutation against Marcion (cf. AH 4.6.2). Orbe, Teología V.3, 96.

${ }^{248}$ AH 5.26.2.

${ }^{249}$ Rousseau and Orbe prefer the present tense reading of audet rather than the imperfect audebat, because he never discusses Satan directly challenging God. The perfect implies that in the New Testament, after learning his fate (Matt 25:41), Satan blasphemes openly but not directly, while the imperfect implies that Satan blasphemed indirectly until he learned his fate and now blasphemes openly and directly. Orbe, Teología V.3, 93.

${ }^{250}$ Steenberg, Irenaeus, 50.

${ }^{251}$ Smith, "Chiliasm," 329.
} 
or spiritual union with Christ, but an earthly, physical kingdom reflected in the prophecies of the Old Covenant. ${ }^{252}$ As a result, the eschatological reading of Genesis, as Steenberg notes, is supported by the "revealed images of the millennial kingdom, as in Jeremias, Isaias, Ezekiel, and John's Apocalypse," but he does not examine the nature of the relationships Irenaeus fashions with Gen $2: 1-3{ }^{253}$ As a result, we advance the thesis of Smith and Steenberg with an analysis of Irenaeus' intertextual reading of Gen 2:1-2 that anticipates the advancement of the believer towards maturity in Christ-likeness. ${ }^{254}$

The broader section of $A H$ 5.25.1-30.4 is oriented by the revelation of the Antichrist in 2 Thess 2:3-4 and in general portrays the recapitulation of all apostasy in the person of the Antichrist. ${ }^{255}$ The coming of the Antichrist will erect division, and all will be subject to the just judgment of God. ${ }^{256}$ The height of apostasy is the Antichrist's desecration of the Temple and the manifestation of his powers, which results in the adoration and elevation of apostasy (Rev 13:2-18). The closing lines of AH 5.28.2 cite Rev 13:14-18, which mentions the number of the beast (Rev 13:18).

The number of the beast is six hundred and sixty-six, which he identifies as the title of the Antichrist who recapitulates the whole apostasy (recapitulationem universae apostasiae) that has transpired during the previous six thousand years. ${ }^{257}$ The number, therefore, refers to both the individual and the arrangement and extent of the divine economy. Irenaeus uses this allusion to the number six that linked with the creation narratives to construct a Millenarian eschatological framework, but Irenaeus is not a strict millennialist because he never presents the 1000-year reign of Christ in an earthly kingdom. Instead, Irenaeus unites Rev 13:18 with Gen 2:1-2 and the imagery of 1,000 years to a day in 2 Pet 3:8 (Psalm 89:4 LXX). Through his appeal to the conclusion of creation (Gen 2:1-2), he interprets the "days" (dies) of creation as six one thousand-year periods with the consummation of creation coming at the conclusion of the 6,000 years and the institution of the

\footnotetext{
${ }^{252}$ Behr, Asceticism, 80. The mystical nature of the eschatological quickly became prominent in Origen and Dionysius of Alexandria. Ibid., 80-2; Orbe, Antropologia, 25-7.

${ }^{253}$ Steenberg, Irenaeus, 60.

${ }^{254}$ Ibid., 98. Although Steenberg is, by all appearances, correct to say that Irenaeus only uses this passage in exegetical contexts. The expressed duel sense (literal and prophetic) of Gen 2:1 in this context suggests that Irenaeus does not merely read this text eschatologically.

${ }^{255}$ AH 5.25.1.

${ }^{256}$ AH 5.26.1-28.1.

${ }^{257}$ AH 5.28.2.
} 
eschatological Sabbath. ${ }^{258}$ As Steenberg concludes, "Irenaeus follows the Asiatic chiliastic tradition in asserting a relationship between the timing or chronology of the Genesis creation narrative (read through the interpretive lens of Apoc 19:1121:27) and the whole economy." ${ }^{259}$ In the same number of days that the world was created, in that same number of millennium periods will the world be consummated (consummatur). ${ }^{260}$ While he reads Gen 2:1-2 literally as the description of the cumulative work of God's creative activity, for Irenaeus it is also a prophecy pointing toward the final consummation of all things. He defends the dual sense of reading Gen 2:1-2 saying: "This is a narrative of things formerly created, as also it is a prophecy of what is to come" (Hoc autem est et ante factorum narratio quemadmodum facta sunt et futurorum prophetia) ${ }^{261}$ Thus, God has created all things with a purpose and trajectory oriented toward consummation. For Irenaeus, there is a dialectical tension between narrative and prophecy.

However, while Steenberg is certainly correct, the timing of the divine economy is not the only reason for Irenaeus' appeal to Gen 2:1-2. He focuses on the language of consummare in Gen 2:1-2, as the fulfillment of God's anthropological trajectory implicitly correlates this concept with the previous works of creation (fecit) in the same passage (and the earlier descriptions of God's creative acts). The contrast between fecit and consummavit reflects the distinction between the literal (narratival) and prophetic readings of Gen 2:1-2. In AH 5.28.4 he develops these connections between the creation of Adam on the sixth day and the consummation of humankind at the conclusion of the sixth thousandth year. He mentions that the same "hands of God" (the Son and the Spirit), who fashioned Adam in the beginning in the image and likeness of God (Gen 1:26), are also moulding the faithful throughout the progression of the economy. Orbe notes that unlike Philo and Origen, Irenaeus does not conceive of two creations (Gen 1:26; Gen 2:7), but of one creation with two aspects. ${ }^{262}$ Gen 2:7 depicts the formation from the earth, while Gen 1:26 relates the continual formation throughout the unfolding economy that

\footnotetext{
${ }^{258}$ AH 5.28.3. Smith, "Chiliasm," 315; cf. AH 4.16.1; Epid 96. Steenberg does not appreciate the nuances of Irenaeus' appeal to Gen 2:1-2 and is also mistaken when he suggests this is Irenaeus' only allusion to this passage. Steenberg, Irenaeus, 98.

${ }^{259}$ Steenberg, Irenaeus, 52.

${ }^{260}$ Orbe, Teología V.3, 185.

${ }^{261}$ AH 5.28.3; Behr, Asceticism, 82. In classical rhetoric a narratio is second stage of oration where the orator gives a narratival account of the nature of the case. Quin 4.2.

${ }^{262}$ Orbe, Teología V.3, 192.
} 
prepares the faithful to receive immortality. The projection of creation, for the Bishop of Lyon, is from the very beginning set on an eschatological course toward the consummative fulfillment in the kingdom of God. He links this discussion with the separation of the wheat and the chaff in Matt 3:12, which is the faithful and the apostate, and the theme of martyrdom, where the suffering of the faithful prepares them for the resurrection. ${ }^{263} \mathrm{He}$ argues the tribulation will purify the faithful and prepare them to be formed once again in the image and likeness of God. ${ }^{264}$

\subsection{AH 5.30.4: The Destruction of the Antichrist (Gen 2:2-3)}

In continuity with the previous section, AH 5.30.4 considers the Antichrist's revelation and subsequent destruction. Irenaeus crafts a succinct eschatological outline beginning with the reign of the Antichrist that lasts three and a half years. His reign is, then, interrupted by the Parousia (Matt 16:27), and three concurrent events accompany the Parousia: Satan will be cast into the lake of Fire (Rev 19:20), the righteous will be gathered into the kingdom on the hallowed seventh day (Gen 2:2-3), and the just will receive the Abrahamic promises (Matt 8:11) ${ }^{265}$ His allusion to the ingathering of the just includes mention of the eschatological "rest" (requietionem, Gen 2:2) when the faithful will recline at the Father's table and feast with Abraham and all the faithful (Matt 8:11). Therefore, with these texts, Irenaeus weaves an eschatological cento, the climax of which is the restoration of the "hallowed seventh day" (septimam diem sanctificatam) of Gen 2:2-3.

\subsection{AH 5.33.1-4: Resurrection and Restoration (Gen 1:27-28, Gen 1:30, Gen}

\section{$2: 2-3)$}

In continuity to the previous discussion, in $A H$ 5.33.1-4, Irenaeus illustrates the nature of the eschatological seventh day of creation with a series of interrelated prophetic passages. Steenberg suggests this section summarizes Irenaeus' chiliastic

\footnotetext{
${ }^{263}$ Behr, Asceticism, 77. He compares this to the Eucharist.

${ }^{264}$ Irenaeus turns to the martyrdom of Ignatius for an example of this purification. He cites Ignatius' words illustrate his point, "I am the wheat of Christ, and am ground by the teeth of the wild beasts, that I may be found the pure bread of God." (frumentum sum Christi, et per dentes bestiarum molor, ut mundus panis Dei inveniar). Ign, Rom 4.1

${ }^{265}$ AH 5.30.4; Orbe, Teología V.3, 282; cf. AH 4.16.1; AH 5.28.3; AH 5.32.2; AH 5.30.1. He suggests Titan (Teitan), Euanqas (Evanthas) and Lateinos (Lateinos), and also concludes the name was suppressed in preference for the number, because the name is not worthy to be proclaimed by the Holy Spirit.
} 
vision of creation, where the creation narratives find their telos in the "cosmic 'Sabbath"'266 Irenaeus speaks of this Sabbath in terms of the Abrahamic blessing and then reminds his readers of Christ's words at the last supper where he proclaimed to his disciples that he would drink wine again with them in the renewed kingdom of God (Matt 26:27-28). This kingdom would be a renewed earth enjoyed by the faithful who are raised to new life (Psalm 103:30 LXX) ${ }^{267}$ In contrast to his Gnostic opponents, this earth and wine is not a celestial place where wine is consumed spiritually without a body, but the renewed earth that produces wine for those resurrected in flesh.

In $A H$ 5.33.2 he describes the nature of life in the eschatological seventh day (Gen 2:2-3) with the imagery of Christ's invitation of the lame, blind, and poor to dinner, rather then friends and neighbors (Luke 14:12-13), and proclaims recompense for those who abandon their earthly possessions for the sake of Christ (Matt 19:29). Alluding to Gen 2:2-3, he describes how the seventh day of creation was sanctified when "God rested from all the works He created" (requievit Deus ab omnibus operibus quae fecit). ${ }^{268}$ Thus, the same will be true of the faithful who dwell in the kingdom of God. They will not engage in any work, but God will prepare them a lavish table overflowing with all kinds of foods. ${ }^{269}$ The episodes of Luke 14:12-13 and Matt 19:29 are the "times of the kingdom" (regni temporibus) reflecting the nature of the cosmic seventh day of creation, which he interprets literally and emphasizes the corporeal and material aspects.

In continuity with the nature of life in the eschaton, in $A H$ 5.33.3-4, Irenaeus discusses the nature of creation in eschatological seventh day. Irenaeus uses intertextual connections to illustrate the nature of life in the kingdom, and confirm the eschatological imagery of the fecundity of the earth. This imagery reflects the original divine intention for creation where Adam lives in obedience to God and creation is peacefully subject to Adam. ${ }^{270}$ This line of argumentation links Gen 1:2728 and Gen 1:30 with Isa 11:6-9 and Isa 65:25. The texts from Isaiah depict the apocalyptic imagery of a harmonious creation where the wolf and the lamb lie down

\footnotetext{
${ }^{266}$ Steenberg, Irenaeus, 53.

${ }^{267}$ AH 5.33.1.

${ }^{268}$ AH 5.33.2.

${ }^{269}$ AH 5.33.2; cf. AH 5.30.4. On this day Abraham received his promised inheritance as cited in Matt 8:11. Irenaeus will support these texts with additional passages in AH 5.34.1-4.

${ }^{270}$ Steenberg, Irenaeus, 55; Orbe, Teología V.3, 442.
} 
together, the lion eats straw and the serpent does not harm an infant. Irenaeus recognizes that some of his contemporaries interpret this imagery allegorically as the conversion of the pagans who come into harmony with righteous faith and while he agrees that this rendering is plausible, he prefers a literal reading depicting the fulfillment in the eschatological kingdom with actual lions and lambs. ${ }^{271}$ This harmonious creation is, for Irenaeus, consistent with the divine intention for creation to be in subjection to humankind (Gen 1:27-28). This also entails that the animals return to their original vegetarian diet (Gen 1:30) they enjoyed before Adam's disobedience. ${ }^{272}$ Thus, in Irenaeus' perspective, the harmonious nature of the original pre-lapsarian creation of Gen 1:27-30 is restored in the eschatological kingdom mentioned in Isa 11:6-9 and Isa 65:25. However, the relationship is one of degree not kind because the state of creation illustrated in Isa 11:6-9 and Isa 65:25 is a more rich and bountiful creation. He even reflects upon the quality and magnitude of the fruit in the kingdom where a lion can be satisfied by such a meager meal. ${ }^{273}$ As we noted earlier, Irenaeus nowhere mentions the texts of Gen 1:6-25 except in his discussion of Marcosian interpretations. In the present context, however, it is possible to infer his views of the nature of the original creation in Gen 1-2. ${ }^{274}$ This is Steenberg's suggestion when he cites Irenaeus' reading of Gen 1:11-12 and Gen 1:24-25. ${ }^{275}$

\subsection{AH 5.34.2: The Restoration of Inheritance (Gen 3:6)}

Like previous sections, this portion also presents a separate network of texts depicting the nature of the eschatological earthly kingdom following the resurrection. To illustrate this new creation, Irenaeus cites Isa 30:25-26 that concludes with the description of the Lord promising his people that he will heal

\footnotetext{
${ }^{271} \mathrm{AH}$ 5.35.4. In AH 5.35.1, Irenaeus notes those who allegorize these prophecies are inconsistent with themselves.

${ }^{272}$ AH 5.33.4.

${ }^{273}$ The first citation in $A H$ 5.34.1-4 is Isa 26:19, which describes the joy of creation at the resurrection of the just, but the rest of the passages more specifically describe the promise and nature of the physical resurrection: Ezek 37:12-14; Ezek 28:25-26; Matt 3:9/Luke 3:8; Jer 16:14-15, 23:7-8; Isa 30:2526; Gen 9:27; Isa 58:14; Luke 12:37-38; Rev 20:6; Isa 6:11-12; Dan 7:27; Dan 12:13; Jer 31:10; Matt 12:5; Isa 31:9-32:1; Isa 54:11-14; Isa 65:18-22.

${ }^{274}$ Steenberg, Irenaeus, 93; cf. Epid 34; AH 5.18.3.

${ }^{275}$ Steenberg, Irenaeus, 55-6; cf. Orbe, Teología V.3, 443. In AH 5.22.4, Irenaeus also references Papias as his source for this material, which implies Papias is the conduit though which the Asiatic chiliastic tradition came to Irenaeus and disseminated to the later tradition. Danielou, Theology of Jewish Christianity, 382; cf. Steenberg, Irenaeus, 54.
} 
the "pain of the stroke" (dolorem plagae). The "pain of the stroke" (dolorem plagae), for Irenaeus, is closely related to Adam's disobedience and the death inflicted upon him as a penalty of his sin (Gen 2:17, Gen 3:6). ${ }^{276}$ The mode of healing is, of course, the resurrection of the faithful who are granted the "inheritance of the fathers" (patrum hereditatem) and the blessing of Japeth (Gen 9:27). ${ }^{277}$ This reference to inheritance also accompanies an allusion to the earth as the inheritance of those who are resurrected from the dead (Isa 58:14) ${ }^{278}$ Together these texts remind the reader that the penalty of death imposed in Gen 1-3 is healed by means of the resurrection and restoration of what the inheritance of was lost through Adam's disobedience.

\subsection{AH 5.36.3: The Resurrection of the Just and the Final Consummation}

(Gen 1:26, Gen 1:31-2:1, Gen 2:2-3, Gen 2:7)

In the closing paragraph of his magnum opus, Irenaeus appears confident that he has demonstrated his eschatological vision for the salvation of the flesh that has dominated the work as a whole. In his final statements, Irenaeus carries on the same intertextual practice that has characterized his exegesis to this point. ${ }^{279} \mathrm{He}$ continues his strong literalist understanding of the eschatological kingdom with a commentary on the blessings imparted to the faithful. These texts center upon the one Father, the one Son, and the one human race that experiences the promise of bodily resurrection and recreation in the image and likeness of God. ${ }^{280}$

A portion of this section survives only in a late Armenian manuscript. Rousseau considers it original and suggests it brings more clarity to the thought of this section. Orbe, on the other hand, evaluates the section and raises some significant questions about its authenticity. While it is clear that the tone is Irenaean, which suggests a close relationship to Irenaeus himself, the insertion

\footnotetext{
${ }^{276}$ Orbe points to the common vocabulary in Rev 13:3, 12 and also suggests the background of Num 21:8. Orbe, Teología V.3, 458; cf. AH 5.28.2.

${ }^{277} \mathrm{AH}$ 5.34.2. The citation of Gen 9:27 is absent from the Latin mss, although Rousseau believes it is original. SC 152.342.

${ }^{278}$ Smith, "Chiliasm," 318.

${ }^{279}$ See SC 153:462.55; Orbe, Teología V.3, 616-617.

${ }^{280}$ Donovan, One Right Reading?, 169. Both Adversus Haereses and the Epideixis conclude with allusions to Gen 1:26. It is not uncommon to read that the concept of recreation in the image of God is a theme that dominates both works as a whole. Wingren, Man and the Incarnation, 213.
} 
breaks the flow of the passage and the balance of scriptural material. ${ }^{281} \mathrm{He}$ also suspects that the insertion is the result of a scribal addition in order to clarify Irenaeus' chiliasm and early Christian debates over the nature of the resurrection(s) in relation to the Millennial Kingdom. He compares this insertion with a similar one from Hippolytus' commentary on Daniel that is clearly inauthentic, and concludes that Irenaeus was subjected to a similar manner of correction. Even though the intertextuality in this section is characteristic of the way Irenaeus reads scripture, but the intertexts are different. ${ }^{282}$

This is important because this insertion cites Gen 1:31-2:2 to speak of the consummation of creation on the sixth day of creation, or the 6000 years, and the eternal rest that proceeds on the seventh day (2 Pet 3:8, Psalm 89:4). Here these texts are interpreted in the same manner as $A H$ 5.28.3, but the intertexts are different. The insertion begins immediately following an allusion to the resurrection of the faithful who dwell in the Millennial Kingdom and eat and drink with Christ (Matt 26:29). In connection to this imagery, Irenaeus calls on Christ's words in John 5:25, 28-29 and the Psalmist's description of the Lord's rest (requies, Psalm 131:14/Psalm 117:20 LXX) communicate the nature of the "first resurrection" (primos resurgere), or the resurrection to life prior to the Millennial kingdom. This is set in contrast to the final resurrection to judgment at the consummation. For the author of this insertion, Gen 1:31-2:2 and Psalm 131:14/Psalm 117:20 LXX confirm the nature and timing of the two resurrections mentioned in John 5:25, 28-29 in relation to the Millennial Kingdom, which is a distinctly Irenaean way of reading texts, and suggests the person was well acquainted with Irenaeus' thought. ${ }^{283}$

Having summarized this intertextual Millenarian presentation, the remaining portion of $A H$ 5.36.3 depicts the nature of the resurrection of the just (Rev 20:5-6) and their inheritance of a restored earthly kingdom (Rom 8:21). He describes how the prophets "harmoniously" (consonanter) prophesy this

\footnotetext{
${ }^{281}$ For Orbe, the introduction seems to break to flow of argument, however, given the Irenaean tone and dependence on scripture, he also suggests that this could be an authentic Irenaean insertion in a later draft. Orbe, Teología V.3, 618.

${ }^{282}$ Compare, for example, the closing lines of Irenaeus' Epideixis (Epid 97-100), which are also debated. A key objection to its authenticity is the lack of any scriptural reference, which is not the case for this insertion.

${ }^{283}$ It is also important to note that Psalm 131:14/Psalm 117:20 LXX appear nowhere else in Irenaeus and John 5:25, 28-29 is found only here and AH 5.13.1.
} 
resurrection of the faithful and restoration of the earth. ${ }^{284}$ These things, Irenaeus concludes, are the work of the same God and Father, who "fashioned humankind" (plasmavit hominem, Gen 2:7) in the beginning and gave them the promises of the future resurrection and the inheritance of the kingdom of God. We have seen how the Father, by means of the Word, is forming humankind throughout the unfolding of the divine economy and preparing the faithful for resurrection. ${ }^{285}$ The fulfillment of these promises, Irenaeus assures the reader, is something that remains unseen (1 Cor 2:9). Orbe provides an extended commentary on the vision of God with respect to 1 Cor $2: 9$ and in relation to $A H 4.20 .5 .^{286}$ He speaks of three different graduated stages of seeing God (prophetice, adoptive, paternaliter) where the faithful, though subject to corruption, continue to advance toward the perfection of the Father by means of the prophetic Spirit in the Old Testament, finally receive adoption mediated by the Son and the Spirit in the New Testament, and in the final consummation they receive the Father's promised resurrection and restoration to eternal life. In a parting shot at his opponents, Irenaeus suggests that not even the angels, who cannot fathom the mysteries of God, can spoil this divinely orchestrated economy of salvation (Pet 1:12) ${ }^{287}$ This mystery is the actualization of God's "handiwork" (plasma) being conformed to the Son and brought to perfection (Gen 2:7). ${ }^{288}$

Irenaeus concludes his refutation by describing, once again, how the "handiwork" (plasma, Gen 2:7) of God, which is incorporated into the Son, will be made after the image and likeness of God (Gen 1:26). ${ }^{289}$ This invokes an image where those who are raised ascend "beyond the angels" (supergrediens angelos). The recreation of humankind in the image of God characterizes the ultimate aim of salvation in Irenaeus. Describing the reciprocal relationship between Genesis and these passages, Steenberg writes: “The 'image and likeness' into which humanity was created is fulfilled and brought to full fruition in the kingdom, and thus

\footnotetext{
${ }^{284}$ AH 5.36.3.

${ }^{285}$ AH 5.14.1; AH 5.15.1-3.

${ }^{286}$ Orbe, Teología V.3, 626-28, see also 628-33, 646-51. The use of paternaliter in AH 4.20 .5 is a key link between these sections.

${ }^{287}$ This use of 1 Pet 1:12 is obscure and Orbe points to at least four different interpretations reflected in parallels with Clement of Alexandria and Epistola apostolorum. Orbe, Teología V.3, 640-41.

${ }^{288}$ The parallel use of conformatum and concorportatum seems to echo Phil 3:21 and Eph 3:6 (AH 1.10.3, AH 5.13.3) and the use of Primogenitus must refer to Col 1:15, 18 and Rom 8:29 (AH 3.15.3, 16.6, 4.20.2). ${ }^{289}$ AH 5.36.3. Steenberg suggests Irenaeus alludes to Gen 1:11-12 and 1:24-25, but this is nowhere explicit. While they may be implied, his argument would have been strengthened if he had developed the uses of Gen 1-3 present in Irenaeus' argument.
} 
through the imagery of the kingdom the nature and character of that image and likeness can be determined." ${ }^{290}$ At last, the handiwork that was fashioned from the earth in Gen 2:7, by means of the unfolding of the economy and the Incarnation, are brought to share in the image and likeness of God (Gen 1:26), partaking in the glory and immortality bestowed by the same Creator and Father.

\subsection{Conclusion}

With the closing allusion to Gen 1:26, Irenaeus rests his argument. From beginning to end, the texts of Gen 1-3 are integrated into his theological reasoning, forming networks of texts in hermeneutically symbiotic relationships. The extensive performance of Gen 1-3 in AH 5 demonstrates the height of Irenaeus' intertextual resourcefulness. As we have seen in previous books, the intertextual performance of Gen 1-3 is shaped by a variety of strategies.

First, Irenaeus continues to use Gen 1-3 to structure his theological polemic. As we have mentioned, in AH 5:15.2-16.2 there is a complex arrangement of theological argumentation that coordinates the narrative of creation in Gen 1-2 with the healing of the blind man in John 9:1-7. In AH 5.23.1-2, Irenaeus presents several intertextual readings of Gen 2:17 that draw from a diverse set of texts including: Gen 1:5, Psalm 89:4 LXX, John 8:44, and Eph 1:10. Thus, the structure of the whole chapter is organized around different interpretations of the divine command given to Adam. While he is comfortable with a variety of intertexts, he is principally concerned with the theological validation that God was proved true and the serpent a liar when Adam disobeyed God's command in Gen 3.

Second, Irenaeus uses a variety of catchwords to intertextually link passages. In AH 5.5.1, the location and description of "paradise" (paradisus) threads together the experiences of Enoch (Gen 5:24), Elijah (2 Kings 2:11), and Paul (2 Cor 12:4), although each one inverts the experience of Adam's expulsion from paradise in Gen 3:23-24. In AH 5.7.1-2 he focuses on an exegetical treatment of the phrase "mortal bodies" (mortalia corpora) in Rom 8:11, which he distinguishes from souls, and connects to the body fashioned from the earth in Gen 2:7. The "mortal body" is the same body that dissolves back into the earth in Gen 3:19, or the animal body of 1 Cor

\footnotetext{
${ }^{290}$ Steenberg, Irenaeus, 56. This imagery of ascending higher than the angels must allude back to Irenaeus' the envy of the angels in the original creation. See Epid 16; cf. Behr, Asceticism, 85.
} 
15:44, that is contrasted with the spiritual body that is raised to new life (1 Cor 15:42-44, John 20:20). In AH 5.12.2-6, Irenaeus links Gen 2:7, Isa 42:5, Isa 57:16, Acts 2:17 and 1 Cor 15:45 with the imagery of "breath" (adspiratio), "Spirit" (Spiritus), and "earth" (terra). Isa 42:5, Isa 57:16, and Acts 2:17 confirm the economic change from the general enlivening through the breath to the particular enlivening by the Spirit. In AH 5.14.1-2 Irenaeus reads the "flesh and blood" (carnis et sanguinis) in 1 Cor 15:50 in correspondence to the body formed in Gen 2:7 and the language of "flesh" or "blood" in Gen 4:10, Gen 9:5-6, Matt 23:35-36, ${ }^{291}$ John 1:14, Luke 19:10, and Col 1:22. In AH 5.15.3, he also compares the original formation from the dust with Jer 1:5, Gal 1:15, and John 9:1 to exemplify how the Son of God formed Jeremiah, Paul, and the blind man in the "womb" (venter). Then, in AH 5.17.1 he connects the sound of God walking in paradise in Gen 3:8 with the "voice" (vocem) proclaiming the forgiveness of sins in the Gospels. Finally, in AH 5.28.3-4 Irenaeus' intertextual logic and millenarian perspective unites the reference to the sixth "day" (dies) in Gen 2:1-2 with the connection of 1,000 years to a day in Psalm 89:4 LXX.

Third, in AH 5 the general theological or typological connections abound. These connections are not located in any specific catchwords, but instead these intertextual relationships are determined theologically and conceptually. Beginning with his anthropology, in AH 5.1.1-3 Irenaeus provides a theological commentary on the nature of plasma as a way to identify the solidarity with the whole human race in the person of Adam. In the same context, he describes the motivation for creation by linking Gen 1:26 with allusions to the predestination and foreknowledge of God in Eph 1:11-12 and 1Pet 1:2. Therefore, creation is a calculated divine decision that providentially unfolds throughout time. In AH 5.6.1, he conflates Gen 1:26 and Gen 2:7 to argue that the plasma of Adam's formation is the substance moulded after the image of God. He also conflates Gen 1:26 with Rom 8:29 to describe the anthropological activity of the Spirit. The "perfect" or "spiritual" person (1 Cor 2:6, 15), according to Irenaeus, is not the man formed in Gen 1:26/2:7, but the person described in 1 Thess 5:23 comprising body, soul and Spirit.

Irenaeus' Christology surfaces in AH 5.21.1-2 where he envisions the protoevangelium is fulfilled in Gen 3:15. The seed in Gen 3:15 is the seed in Gal 3:19 and the one born of a woman in Gal 4:4. He is also the Son of the Father who

\footnotetext{
${ }^{291}$ Luke 11:50-51.
} 
proclaims the command in Gen 3:15. Furthermore, the notion of being born of a woman overturns the nature and function of Eve in the Garden. Just as Eve was taken out of Adam and Satan deceived Adam by means of this woman, so also Christ was born of a woman so that he might vanquish the same enemy who snared Adam. In addition, the vanquishing of Satan is linked with the first temptation of Matt 4:210. ${ }^{292}$ Just as Adam was deceived though eating in Gen 3:6, now Christ, even in a state of hunger, vanquished the same enemy by abstaining from eating.

Finally, the concluding chapters of AH 5 provide some eschatological reflection on the nature of the kingdom of God and the "hallowed seventh day" of creation. Irenaeus weaves an eschatological cento in $A H$ 5.30.4 that concludes with the restoration of creation on the "hallowed seventh day" of Gen 2:2-3. This day is characterized by a number of events and passages that describe the restoration of the faithful sitting at the table of the Lord in Matt 8:11. The same perspective on the eschatological seventh day of creation is seen in AH 5.33.1-4 where Irenaeus envisions the faithful are raised to life on a restored creation (Gen 27:27-29, Matt 13:38, Luke 14:12-13, and Matt 19:29). In the same context, the passages of Isa 11:6-9 and Isa 65:25 describe the restoration of the kingdom to its original subjection and harmony in Gen 1:27-30. The future kingdom depicted in Isa 11:6-9 and Isa 65:25, will be even more fruitful and plentiful than the original creation in Gen 1:27-30. The same kind of eschatological intertextual weaving returns in the closing chapter of $A H$ 5.36.3, where Irenaeus connects a network of citations linked through a theological vision for the eschatological kingdom of God.

The Adam-Christ typology also pervades Irenaeus' intertextual exegesis in $A H$ 5. In $A H$ 5.1.1-3 he reads the Incarnation in Luke 1:35 in light of the creation in Gen 2:7, and these connections are substantiated by the Adam-Christ typology expressed in 1 Cor 5:7 and the reference to divine plural in Gen 1:26, so that the same divine persons creating in Gen 2:7 are also active in Luke 1:35. In AH 5.2.1 Irenaeus provides a sophisticated soteriological connection between the substance of Adam's formation and the substance of Christ's sacrifice. Even though Satan had taken God's creatures captive (Gen 3:1-6), Christ had come to retrieve "his own" (ipsum) creation (Gen 2:7, John 1:11), which is the ancient plasma of Adam, and redeem it by his own flesh and blood (Eph 1:7, 1 Tim 2:6). In AH 5.12.2-6, Irenaeus

\footnotetext{
${ }^{292}$ Luke 4:6-7.
} 
utilizes a Pauline anthropological tension between the first Adam and the second Adam established in 1 Cor 15:45-46, and contrasts the life given by the breath in Gen 2:7, which is temporal, with the life given by the Spirit in 1 Cor 15:45, which is eternal. However, the most developed group of typological connections are located in $A H$ 5:15.2-16.2. Irenaeus provides a complex method of theological argumentation that correlates John 9:1-7 with Gen 1-2 through a variety of texts including: Gen 1:26, Gen 2:7, Gen 3:6, Gen 3:9, Gen 3:19, Jer 1:5, Luke 15:4-6, Luke 19:10, John 1:14, John 5:14, John 9:1-7, Gal 1:15, Phil 2:8, and Titus 3:5. Irenaeus argues that Christ revealed himself as the one through whom all things were created in Gen 1-2, so that the healing of the blind man becomes a reenactment of the creation from the dust in Gen 2:7. Furthermore, the mention of the "work of God" in John 9:3, the fashioning of the eyes from the dust in John 9:6, and the washing in John 9:7 all point to conceptual and theological connections with the creation of all things by means of the Word of God. The Adam-Christ typology surfaces again in AH 5.16.2 where he links Gen 1:26 with the Incarnation in John 1:14 and a discussion of the passion in Gen 3:6 with Phil 2:8 to describe how the first Adam's disobedience in Gen 3:6 is overturned by the second Adam's obedience in Phil 2:8.

Fourth, Irenaeus continues to utilize the images in Gen 1-3 to illustrate his theological perspective and the activity of his opponents. In AH 5.1.1-3, he utilizes the bread-making imagery of 1 Cor 5:6-7 to interpret the "human-making" imagery of Gen 2:7 and Luke 1:35. The Gnostics, for Irenaeus, remain in the "old leaven" of Adam's formation, who was conquered and expelled from paradise. In AH 5.3.1, he addresses the power of God to raise the flesh in Heb 11:19 and 1 Cor 15:53, and then exemplifies this power to raise the flesh with the image of God's creative power in Gen 2:7. In AH 5.5.1-2, the "Hands of God," drawn from allusions to Gen 1:26 and Gen $2: 7$, communicate the notion of preservation and protection of the substance of the flesh, which is substantiated by the experiences of Enoch (Gen 5:24), Elijah (2 Kings 2:11), Jonah (Jonah 2), the longevity of the patriarchs (i.e. Gen 5:2-32, Gen 9:29), and Shadrach, Mechach, and Abednego (Dan 3:19-25). In AH 5.20.2, Irenaeus combines the imagery of Gen 2:8, Gen 2:16-17, Rom 12:3, and Eph 1:10 to compare the Gnostics with deception of the serpent in the Garden. The faithful, for Irenaeus, find themselves in the same position as Adam and he encourages them to eat from all trees 
of the garden, that is all the scriptures, but not of the tree of knowledge of good and evil, which is the teaching of the Gnostics.

Fifth, Irenaeus continues to use the classical general-to-particular manner of argumentation. In $A H$ 5.8.1, the faithful received the Spirit as a pledge (Eph 1:14, Rom 8:9,15) leading them to the fullness of the Spirit that is given in the final consummation (Gen 1:26, 1 Cor 13:12). Similarly, he argues that the breath is given to all, while the Spirit is given particularly. In AH 5.12.2, he develops the contrast between the universality of the breath and the particularity of the Spirit with allusions to Gen 2:7, 1 Cor 15:45, Isa 42:5, and Isa 57:16.

Therefore, from the opening pages of his refutation to his closing citation of Gen 1:26, every decisive aspect of his theological argumentation includes mention of these early creation accounts read in continuity and harmony with the rest of the scriptural witness. Irenaeus is nowhere content to read Genesis apart from the rest of scriptural revelation, but following his intertextual perspective he applies a variety of reading strategies and theological perspectives that serve to unite a variety of texts within his argumentation. 


\section{CHAPTER 7: CONCLUSION}

\subsection{Introduction}

This evaluation of the intertextual reception of Gen 1-3 in Irenaeus exposes the wide range of texts that commune with the creation accounts in his argumentation and exegesis. With Gen 1-3 as our textual landmark, we have shown how Irenaeus reads scripture in continuity with other scriptural texts. For Irenaeus, therefore, Gen 1-3 must be read within a network of interrelated texts, which naturally characterizes his exegesis as intertextual (or inter-scriptural). ${ }^{1}$ Farkasfalvy, writing nearly 50 years ago, concluded that the fundamental feature of Irenaeus' exegesis is harmony (consonans), and subsequent studies have substantiated his view. ${ }^{2}$ Scriptural harmony is the "theological norm" and the "principal result" of Irenaeus' exegesis. ${ }^{3}$ Likewise, the recent discussions on intertextuality in Fishbane, Boyarin, Hays, and Young have raised our awareness of the diversity and influence of intertextuality in the ancient world. We have seen how, for Irenaeus, scripture passages are like carefully crafted tiles framed within the mosaic of a king ( $A H$ 1.8.1), or lines in a Homeric poem properly set in their narratival arrangement (AH 1.9.4), or finely tuned instruments projecting a single hymnic melody to God ( $A H$ 2.28.3). The interpretation of any one part of scripture requires the involvement of other scripture passages (AH 3.12.9). It is fitting and necessary that the interpreter of Irenaeus reads Irenaeus as he reads scripture.

However, over the last 50 years the scholarly interest in Irenaeus as an exegete has gained significant momentum and produced some excellent monographs, but as we observed this trajectory of Irenaean scholarship has overlooked the intertextual nature inherent to Irenaeus' own hermeneutical project. These studies applied critical methods that isolated his reading of particular segments of scripture, including his reading of individual passages, chapters, or books, and which necessarily disconnected the textual networks and scriptural harmonies that defined his exegetical practice. While this is evident in studies on Pauline and Johannine literature, recent works on Genesis also reflect this

\footnotetext{
${ }^{1}$ AH 2.27.1; AH 2.28.3; AH 3.12.9.

${ }^{2}$ Farkasfalvy, "Theology of Scripture," 328; Margerie, Introduction, 69-70; Reventlow, History, 173; Brox, "Irenaeus," 483-506; Grant and Tracy, A Short History, 49-50.

${ }^{3}$ Farkasfalvy, "Theology of Scripture," 328.
} 
perspective. We have shown that, in terms of Genesis, Orbe, Kannengiesser, and Jacobsen argued for a closer scrutiny of Irenaeus' hermeneutical practice as an avenue into his thought. ${ }^{4}$ Steenberg went a step further and provided an integrative analysis of Irenaeus' theology of creation based upon allusions to Gen 1-11, but the integration that characterizes his theological perspective is also true of his applied exegesis. ${ }^{5}$ Finally, Holsinger-Friesen continued to press the importance of Irenaean hermeneutics, but his isolation of Gen 1:26 and Gen 2:7 apart from the Bishop's textual networking continued to marginalize the more fundamental and sophisticated aspects of Irenaeus' use of scripture. ${ }^{6}$ Moving beyond these contributions, this present work has investigated the performance of Gen 1-3 in Irenaeus, not by isolating these passages from their natural textual connections, but instead making these relationships the focus of our inquiry. From these intertextual relationships we were able to discern an array of reading strategies that Irenaeus employs as he articulates his theological arguments.

In this conclusion we provide a measure of synthesis and general analysis regarding Irenaeus' use of Gen 1-3. In the first part, we underscore Irenaeus' presentation of the Gnostic reading of Gen 1-3 that, as he observes, bears some resemblance to his own intertextual hermeneutical practice, even if the nature of the textual relationships are theologically distinct. Irenaeus' description of the Gnostic intertextual use of Gen 1-3 was framed into four procedural methods including: catchwords, gametria, prosopological interpretation, and a "plain sense" reading. In the second part, we provide synthesis and summary of Irenaeus' reading of Gen 1-3 through analyzing the particular function of Gen 1-3, and the variety of intertextual methods that guide his reading. From our analysis we have delineated a set of conceptual classifications that characterize his practice, including: an organizational or structural function, illustrative identification and application, catchwords or verbal connections, prosopological (or prosopographical) interpretation, a literal or "plain sense" reading, general theological or typological connections, narratival or canonical arrangements, and a general-to-particular

\footnotetext{
${ }^{4}$ Orbe, "Cinco exegesis"; Kannengiesser, "The «Speaking God»"; Jacobsen , "The Importance of Genesis 1-3."

${ }^{5}$ Steenberg, Irenaeus, 4.

${ }^{6}$ Holsinger-Friesen, Irenaeus, 2, 222-5.
} 
argumentation. We will discuss each of these below in summary form and describe how these methods served Irenaeus' intertextual reading of Gen 1-3.

\subsection{Irenaeus on the Gnostic Reading of Gen 1-3}

Irenaeus' refutation of Gnosis is most frequently set in terms of rejecting their exegesis of scripture. Irenaeus is acutely concerned with Gnostic adaptation, transposition, and/or division of passages from their proper linguistic, narratival, and theological framework. ${ }^{7}$ However, like Irenaeus, the Gnostics use catchwords or linking terms to blend passages within scripture. This is not a widespread practice in Irenaeus' summation of Gnosis since they are much more interested in conforming the narrative to their mythological system than harmonizing the scriptural narrative within itself. A key catchword found among both the Valentinians and Marcosians is the language of "earthly" (choicum) drawn from 1 Cor 15:47. ${ }^{8}$ This description is used to explain the substance of the man fashioned from the "dust" (limus) or "earth" (terra) in Gen 2:5-7. Some Marcosians even contrast this formation with Adam's “fleshy” (carnalem) part formed in Gen 3:21.

Second, the Gnostics use gametria, which is a numerological method of connecting texts. Marcus and the Marcosians are drawn to the "sixth" (sexta) day of creation in Gen 1:31, but the Marcosians also link together groupings of four, ten, twelve, and thirty found throughout Gen 1:1-27. These various numbers validate the Pleromic system of aeons, and in each case they connect these numerological groupings with other scripture passages. ${ }^{9}$ This type of reading ignores the immediate context of the passages and the larger narratival framework of scripture, but preferring instead to focus exclusively upon the numbers or quantities represented in a given passage, and their relationship to a mythological system distinct from scripture.

Third, the Gnostics employ a type of prosopological interpretation whereby they identify the figures in their own mythical system with different persons in the Genesis narrative. In $A H$ 1.24.1-2 and $A H$ 1.30.1-9, the speakers and characters in Gen 1:26 and Gen 2:7 are the Demiurge and his angelic servants. Ophites also identify Jaldabaoth and his angelic sons as the divine beings proclaiming the command of

\footnotetext{
${ }^{7}$ AH 1.pr.1; $A H$ 1.3.6; $A H$ 1.8.1; $A H$ 1.9.4; AH 4.pf.4; $A H$ 5.13.2; $A H$ 5.20.1-2.

${ }^{8} \mathrm{AH}$ 1.5.5; $\mathrm{AH}$ 1.18.2.

${ }^{9} \mathrm{AH}$ 1.14.6; AH 1.18.1-2.
} 
Gen 2:17 and working through the activity of Adam and Eve's disobedience in Gen 2:22, Gen 3:1-6, Gen 3:7, and Gen 3:20. They frequently draw from the divine proclamation of Isa 45:5/46:9, and the angelic imagery of Eph 1:21 to describe the nature and character of these divine beings.

Finally, the Gnostics do provide a type of "plain sense" reading of Gen 1-3 in the sense that the read the texts in light of their immediate literary context. In other words, they read Gen 1-3 as a coherent, literal description of creation. However, they carefully amend the identity of the characters and the significance of the events. From the Gnostic perspective the problem is that Moses wrote before the full revelation of knowledge given in Christ, so his account must be revised where he does not conform to the Gnostics doctrines. ${ }^{10}$ As a result, their theological synthesis unifies diverse passages by means of underlying patterns of connection in order to elucidate the Gnostic myth. ${ }^{11}$ These methods of Gnostic intertextuality compete with similar methods that Irenaeus employs in the latter books of Adversus Haereses.

\subsection{Irenaeus' Intertextual Reading of Gen 1-3}

In addition to the Gnostic intertextuality Irenaeus describes in $A H 1$, this study also discloses the wide-ranging diversity of intertextual relationships that Irenaeus forms with Gen 1-3. Guided by his own theological framework, Irenaeus reads a remarkable assortment of texts in continuity with Gen 1-3. He is not necessarily beholden to particular sets of relationships, but rather, through his theological argumentation, freely forms (and re-forms) interrelated networks of texts. As a result, it is improper to conclude that Irenaeus is particularly Pauline or Johannine in his reading of creation. ${ }^{12}$ He never relies upon a singular author or genre and, in fact, in many cases his argument rests on the continuity between Moses, the prophets, and the apostles. He makes this argument clear in AH 2.2.5 where he remarks that the faithful must read the Mosaic account of creation in continuity with the apostolic testimony. The Mosaic account, according to Irenaeus, is a more trusted authority (Heb 3:5) on creation than the Gnostic intellectuals who

\footnotetext{
${ }^{10}$ Giverson, "The Apocryphon of John," 75-6; Holsinger-Friesen, Irenaeus, 61, 101-3.

${ }^{11}$ Grant, Irenaeus, 25.

${ }^{12}$ Wingren, Man and the Incarnation, $\mathrm{xx}$.
} 
continually revise or amend Genesis in accordance with their own theological perspective.

Therefore, from beginning to end every decisive aspect of his theological argumentation includes mention of these early creation accounts read in continuity and harmony with the rest of the scriptural witness. Irenaeus is no where content to read Genesis apart from the rest of scriptural revelation, but following his intertextual perspective he applies a variety of reading strategies and theological perspectives that serve to unite a variety of texts within his argumentation. The sophistication of these intertextual networks communicates a mastery of the scriptural material that cannot be assumed as mere received traditions. ${ }^{13}$

\subsubsection{Organizational and Structural Function}

To begin with, the Bishop of Lyon frequently organizes or structures many of his arguments with the contents of Gen 1-3. These organizational functions repeatedly unite passages in Irenaeus' exegetical logic and expose the way his arguments are naturally guided by the conceptual imagery inherent to scripture. First, Irenaeus uses Gen 1-3, especially Gen 1:26, to frame his work as a whole. While Genesis imagery surfaces early and often, the whole work concludes with a citation of Gen 1:26. ${ }^{14}$ We have also observed that the majority of the allusions to Gen 1-3 surface in the opening sections of the chapter and paragraph divisions in AH. By our calculation well over half (59\%) of the sections we evaluated contained an allusion to Gen 1-3 in the initial paragraph. If we include the final paragraph the percentage is greater than $70 \%$. This suggests that Irenaeus tends to allude to Gen 1-3 in the opening or closing portions of his argument. To put it another way, the contents of Gen 1-3 function as transitional texts within the flow of his thought.

Second, the texts of Gen 1-3 participate in specific organizational schemes such as chiasms, supportive texts, or structural markers. While they are essential to his polemical representation of Gnosis in $A H$ 1-2, in $A H 3$ the organizational function truly comes to the forefront in the chiastic arrangements of $A H$ 3.18.1-18.7, $A H$ 3.19.1-21.10, and $A H 3.23 .1-8$. The parallel allusions to Gen 2:5 in $A H 3.18 .1-2$ and $A H$ 3.18.7 frame the chiasm as a means of extending the Adam-Christ typology. The

\footnotetext{
${ }^{13}$ Orbe, Teología V.1, 13-23.

${ }^{14} \mathrm{AH}$ 5.36.3. Gen 1:26 is cited in the closing line of the argument portion of the Epideixis (Epid 97).
} 
allusions to Gen 2:5 and 3:5 drive the first half of his anti-docetic argument in $A H$ 3.19.3-20.1. The climax of his recapitulative argument is found in AH 3.23.1-8 with the theological arrangement of the narrative of Gen 3-4. Gen 3:5 frames this chiasm as a whole, but he also alludes to an array of Genesis texts including: Gen 1:26, Gen 3:7-8, Gen 3:10, Gen 3:13, Gen 3:14, Gen 3:15, Gen 3:16, Gen 3:17-19, Gen 3:21, and Gen 3:23-4. In addition, Irenaeus uses a host of intertexts to interpret these passages including: Gen 4:7-8, Gen 4:9, Gen 4:11, Matt 12:29, Matt 25:41, Psalm 90:13 LXX, Prov 1:7, Luke 10:19, Rom 5:12, 17, Rom 6:2, 10, 1Cor 15:26, 54-55, Gal 3:16, and Rev 20:2. The whole arrangement completes Irenaeus' theology of recapitulation, and reveals the Christological fulfillment of the prophecy of Gen 3:15. In AH 4, Gen 1-3 functions predominately as a supporting text for the interpretation of the words of the Lord and the Gospel parables. AH 4.34.4, AH 4.36.2-6, and AH 4.40.3, for example, offer commentary on a series of parables that incorporate an allusion to Gen 1:26, 2:7 or 3:15. However, in AH 4.38.1-4 Gen 1:26, Gen 2:7, and Gen 3:5 are drawn to the forefront and become controlling texts arguing for perfection in the image of God. Finally, the most complex structural function of Gen 1-3 occurs in AH 5. While texts throughout $A H 5$ continue to serve in a supporting role, the entire section of $A H$ 5.15.1-24.4 is an organized attempt to re-read the events of Gen 1-3 in light of three principal features of the Christ event: Incarnation, crucifixion, and temptation. ${ }^{15}$ Each of these episodes of Christ's life is read with Gen 1-3 in one hand and the Gospels in the other. In AH 5.15.2-16.2, in particular, there is a complex method of theological argumentation that is arranged around the connections between John 9:1-7 and Gen 1-2. In AH 5.23.1-2, Irenaeus presents several intertextual readings of Gen 2:17 that draw from a diverse set of texts including: Gen 1:5, Psalm 89:4 LXX, John 8:44, and Eph 1:10. While he provides a series of intertexts to read alongside Gen 2:17, in each case he is principally concerned with the theological demonstration that God was proved true and the serpent a liar when Adam disobeyed God's command in Gen 3. Finally, the Sabbath day of rest in Gen 2:1-3 organizes the prophetic picture of the kingdom of God in the closing chapters $A H$ 5.28-36.

\footnotetext{
${ }^{15}$ Orbe, Theología V.2, 3, 104-5, 345; See also Donovan, One Right Reading?, 153-4.
} 


\subsubsection{Illustrative Identification or Application}

Irenaeus also applies the images and language of Gen 1-3 in an illustrative manner. In many cases Irenaeus uses these textual images for polemical purposes and identifies those of his contemporary setting with particular characters and images in the protological accounts. His most frequent application is the characterization of the Gnostics as contemporary manifestations of the serpent (AH 3.23.1, 8, AH 4.pf.4, and $A H$ 5.26.2). Just as the serpent was leading Adam and Eve astray in Gen 3:1-5, so also are the heretics deceiving the faithful and leading them away from the true knowledge of God. In AH 3.23.8 and AH 5.26.2 he adds that the eternal fire of Matt 25:41 was prepared for Satan and his companions who attempt to deceive God's people.

Then, in AH 3.24.1 he imagines the breath of God that is imparted to Adam in Gen 2:7 as the church, or the vassal of Matt 12:29, that has received the precious deposit of the Spirit. Similarly, in AH 5.1.1-3, he utilizes the bread-making imagery of 1 Cor 5:6-7 to interpret Gen 2:7 and Luke 1:35. The Gnostics, for Irenaeus, remain in the "old leaven," which is the "old" substance of Adam's formation, who was conquered and expelled from paradise. In AH 5.3.1, he alludes to the power of God to raise the flesh in Heb 11:19 and 1 Cor 15:53 and then illustrates this power with God's creative work in Gen 2:7. In AH 5.20.1-2, Irenaeus describes the church as the manifestation of paradise in the present age and petitions the Gnostics to flee to the church and be nourished by the scriptures. Combining the imagery of Gen 2:8, Gen 2:16-17, Rom 12:3, and Eph 1:10 he imagines that the faithful are in same position as Adam. Just as God commanded Adam, he encourages the faithful to partake from all the trees of the garden, or all the scriptures, but refrain from the tree of knowledge of good and evil, that is the teaching of the Gnostics.

\subsubsection{Catchwords or Verbal Connections}

Irenaeus also coordinates passages through common vocabulary or catchwords that make philological connections between texts. The imagery of Gen 1-3 provides Irenaeus a seedbed of images that serve to draw connection with a wide range of scriptural references. In most cases these intertextual connections qualify or define the meaning of related terms in other scriptural contexts. First, the creation 
imagery in Gen 1, and particularly God speaking creation into existence in Gen 1:3 ${ }^{16}$ corresponds to God speaking in Psalm 33:9 $\mathrm{LXX}^{17}$ and God creating by means of the Word in John 1:3. The imagery of creating flora (Gen 1:11), including the grapevine, and water (Gen 1:9) relate to the miracle of the wedding feast at Cana where Jesus changes water into wine..$^{18}$ The catchword "all things" (omnia) is the linking reference for several texts in AH 4.20.1-4a (Mand 1, Mal 2:10, Eph 4:6, and Matt 11:27), all of which serve as commentary on Gen 1:26 and Gen 2:7.

The most common linking term is the substance of Adam's flesh or "formation" (plasma) and a host of similar images analogous to this substance. In AH 1.9.3 and $A H$ 3.18.1, the imagery of "flesh" (caro) in John 1:14 parallels the substance of Adam's formation in Gen 2:7. ${ }^{19}$ Similar imagery is located in AH 3.18.7, but he adds the allusion to the "virgin soil" (terra rudis) in Gen 2:5. In AH 3.19.3, we find analogous descriptions that relate Adam's "formation" (plasma) in connection to the lost "sheep" (ouem) of Luke 15:4, and the "earth" (terra) of Eph 4:9. AH 3.21.10 also follows with similar connections of Adam's “formation" (plasma) with the "untilled earth" (rudi terra) of Gen 2:5, the Word of God who forms all things (John 1:3) and the Adam-Christ typology of Rom 5:12, 19. In AH 3.22.1, Irenaeus describes the "meek" (mites) nature of the flesh that is fashioned from the "earth" (terra, Matt 5:5, Gen 2:7). Then, in AH 5.7.1-2 he focuses on an exegetical treatment of the phrase "mortal bodies" (mortalia corpora) in Rom 8:11, which he distinguishes from souls, and links to the body fashioned from the earth in Gen 2:7. The "mortal body" is the same body that dissolves back into the earth in Gen 3:19 or the animal body of 1 Cor 15:44, which also stands in contrast to the spiritual body that is raised to new life (1 Cor 15:42-44, John 20:20). In AH 5.14.1-2, Irenaeus reads the "flesh and blood" (carnis et sanguinis) in 1 Cor 15:50 in correspondence to the body formed in Gen 2:7 and references to "flesh" or "blood" in Gen 4:10, Gen 9:5-6, Matt 23:35-36, John 1:14, Luke 19:10, and Col 1:22. He argues that Christ's advent involved the assumption and salvation of flesh and blood. He compares the original formation from the dust in AH 5.15.3 with Jer 1:5, Gal 1:15, and John 9:1 to describe how the Son of God formed Jeremiah, Paul, and the blind man in the "womb" (venter).

\footnotetext{
${ }^{16}$ Gen $1: 3,6,9$, etc.

${ }^{17}$ Psalm 148:5 LXX.

${ }^{18}$ AH 3.11.5.

${ }^{19}$ AH 1.9.3; $A H$ 1.22.1.

${ }^{20}$ Luke 11:50-51.
} 
In addition to the imagery of the body, the language of "life" (vitae) and “forever" (saeculum) connects Gen 2:7, Psalm 32:9 LXX, ${ }^{21}$ Psalm 20:5 LXX, and Luke 16:10 in AH 2.34.3-4. Elsewhere, Irenaeus threads Gen 2:7, Isa 42:5, Isa 57:16, Acts 2:17 and 1Cor 15:45 with the imagery of "breath" (adspiratio), "Spirit" (Spiritus), and "earth" (terra). ${ }^{22}$ Isa 42:5 and Isa 57:16 confirm the economic change in the enlivening strength of the breath and the Spirit, while Acts 2:17 examples the new administration of the Spirit. AH 3.23.6-8 boasts the connecting imagery of "life" (vitae, Gen 2:9, Rom 6:10), “serpent” (serpentem, Gen 3:15, Psalm 90:13 LXX, Rev 12:9/20:2), "seed" (semen, Gen 3:15, Gal 3:16,19), and the verb “to tread upon" (calcare, Gen 3:15, Luke 10:19).

Alongside the anthropological imagery, the language of "paradise" (paradisus) links 2 Cor 12:4 with God placing Adam in paradise in Gen 2:15. ${ }^{23}$ In $A H$ 5.5.1, the location and description of "paradise" (paradisus) unites the experiences of Enoch (Gen 5:24), Elijah (2 Kings 2:11), and Paul (2 Cor 12:4). In AH 5.17.1, the sound of God walking in paradise in Gen 3:8 is linked with the "voice" (vocem) proclaiming the forgiveness of sins in the Gospels. Then, in AH 3.23.2 he describes the condemnation of the serpent, or Satan, with the links between the curse of Gen 3:14 and the eternal fire in Matt 25:41 that prepared for those who are "accursed"

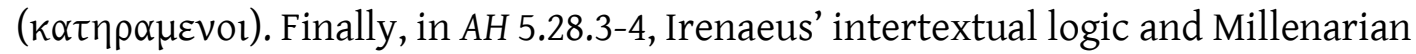
perspective unites the reference to the sixth "day" (dies) in Gen 2:1-2 with Psalm 89:4 LXX.

\subsubsection{Prosopological Interpretation}

Irenaeus follows a style of prosopological (or prosopographical) interpretation where he identifies the characters, titles, or activities of Gen 1-3 with distinctive divine persons. He appeals to a variety of passages to prove the activity of the Word and Wisdom with the Father in creation. In AH 1.22.1, he links the identity of the Creator in Genesis with the "Father" (Pater) of Abraham (Exod 3:6) and the "Father" (Pater) of Jesus (Eph 1:3), and this same Creator and Father fashioned all things by means of the Word (John 1:3). Irenaeus also assumes the act of creation involves not only the Father, but also the Word and Wisdom of God. Beginning in Gen 1:3, he

\footnotetext{
${ }^{21}$ Psalm 148:5-6.

${ }^{22} \mathrm{AH}$ 5.12.2-6.

${ }^{23} \mathrm{AH} 2.30 .7$.
} 
describes how God created all things by means of the Word (John 1:3) ${ }^{24}$ In AH 2.30.9, he conflates references to Word of God in Heb 1:3 and the Wisdom of God in Mand 1 in order to communicate the activity of the Word and Wisdom in creation. In $A H$ 3.11.5, the connections between Gen 1-2 and John 2 are arranged to identify the Creator in Gen 1 with the one who performed the miracle at the wedding in Cana. In $A H$ 3.21.10, he again links John 1:3 and Gen 2:7, and then in $A H 3.24 .2$ he alludes to the Word of Psalm 32:6 LXX and the Wisdom of Prov 8:30 in continuity with Gen 1:26, Gen 1:28, and Gen 2:7. In AH 4.pf.4, Irenaeus interprets the proclamation of Gen 1:26 as the two Hands of God, the Son and the Spirit, and then in AH 4.6.2 he converts the verbal forms of the acts of creation into titles for God as a means to identify the Creator. The same dialogical emphasis is found in $A H 4.10 .1$, where Irenaeus alludes to the Son of God inquiring after Adam in Gen 3:9. In AH 4.20.4, Irenaeus uses Prov 3:19-20, Prov 8:22-25, Prov 8:27-31 in connection with Gen 1:26 to explain the "Trinitarian" nature of God creating in Genesis. The same theological reading of creation is found in $A H$ 4.32.1, where he alludes to John 1:3, Eph 4:5-6, 1516, and Col 2:19. In AH 5.1.1-3, Irenaeus interprets also the Incarnation in Luke 1:35 in a typological relationship to the formation of Adam in Gen 2:7, and the reference to divine plural in Gen 1:26. The same divine persons creating Adam in Gen 2:7 are also active in the Incarnation in Luke 1:35. Finally, in AH 5.5.1-2 the "Hands of God," drawn from allusions to Gen 1:26 and Gen 2:7, communicate the notion of preservation and protection of the substance of the flesh.

\subsubsection{Literal or "Plain Sense" Reading}

In a few instances, Irenaeus will provide a "plain sense" reading of Gen 1-3 that interprets these passages as a literal account of creation, without explicit reference to texts outside of Gen 1-3. Generally speaking, he frequently conflates Gen 1:26 and Gen 2:7 into one creation account of humankind in two aspects: the creation from the dust and creation in the image of God. ${ }^{25}$ In $A H$ 2.30.7 he also reads Gen 1:1, Gen 2:7, and Gen 2:15 as a summary of God's creative acts. However, AH 3.23.1-8 provides a literal or "plain sense" reading of Gen 3, even though the texts are crafted into the structure of a chiasm. While Gen 3:5 frames the whole chiasm, he cites an array of

\footnotetext{
${ }^{24} \mathrm{AH} 2.2 .5$.

${ }^{25}$ See, for example, AH 4.pf.4.
} 
Genesis texts including: Gen 1:26, Gen 3:7-8, Gen 3:10, Gen 3:13, Gen 3:14, Gen 3:15, Gen 3:16, Gen 3:17-19, Gen 3:21, and Gen 3:23-24. In doing so, he describes the disobedience and judgment of Adam, Eve, and the serpent as the fulfillment of Gen 3:15. These instances prove that the original context is a context to read Gen 1-3, but by no means the most important context.

\subsubsection{General Theological or Typological Relationships}

There are also general conceptual or theological connections that are not necessarily linked though specific verbal relationships. It is common for these connections to have some Christological influence that results in theologically symbiotic relationships between these Genesis passages and other scriptural references. While Irenaeus is not necessarily thinking in terms of traditional theological disciplines, clearly Irenaeus' doctrine of God, revelation, anthropology, Christology, and eschatology guide his reading of Gen 1-3. To be sure, these doctrines are not mutually exclusive and are carefully integrated in his polemical arguments. In addition, Irenaeus offers a series of typological relationships that influence his intertextual reading of Gen 1-3 including: Adam-Cain, Adam-Jonah, Adam-Christ, and Eve-Mary.

In the first instance, the knowledge of God as the Creator of all things is an epistemological foundation for his theological framework. These textual referents communicate the revelatory aspect of God's creative acts and the nature of the Creator-creature distinction. Irenaeus discusses the knowledge of God and its limits in $A H$ 2.26.1 with the intertextual use of Gen 1:26, Gen 2:7, 1 Cor 8:1, John 15:9-10 and 1 Cor 2:2. He argues his opponents reflect the puffed up knowledge of 1 Cor 8:1 that is contradictory of the Creator-creature relationship established in Gen 1-2. A few chapters later, he suggests the faithful should content themselves with this clear revelation of God, which he describes with a view of progressive sanctification that moves from creation toward perfection in the divine likeness through an interlocking set of textual references including: Gen 1:1, Gen 1:26/2:7, Gen 1:28, Heb 7:7, Job 3:16, and Matt 3:12. ${ }^{26}$ Finally, the whole section of AH 5:15.2-16.2 offers a complex intertextual correlation of John 9:1-7 with Gen 1-2 through a variety of texts including: Gen 1:26, Gen 2:7, Gen 3:6, Gen 3:9, Gen 3:19, Jer 1:5, Luke 15:4-6,

\footnotetext{
${ }^{26} \mathrm{AH} 2.28 .1$
} 
Luke 19:10, John 1:14, John 5:14, John 9:1-7, Gal 1:15, Phil 2:8, and Titus 3:5. For Irenaeus, Christ revealed himself as the one through whom all things were created in Gen 1-2, so that the healing of the blind man becomes a reenactment of the creation from the dust in Gen 2:7. Furthermore, the mention of the work of God in John 9:3, the fashioning of the eyes from the dust in John 9:6, and the washing in John 9:7 all point to conceptual and theological connections with the creation of all things by means of the Word of God.

While Irenaeus' reflection on anthropology is controlled by an Adam-Christ typology, he also reflects more generally on the nature of the human person, the relationship between the body and soul, and the bodily resurrection. In AH 2.34.3-4 Irenaeus addresses the basic anthropological connection between the soul and the body through the harmonization of Gen 2:7, Psalm 20:5 LXX, Psalm 32:9 LXX, ${ }^{27}$ and Luke 16:10. He argues that since the soul does not have life naturally but partakes of life from God, the extent of life is dependent upon the will of the Creator. In $A H$ 5.1.1-3, he provides a theological commentary on the nature of plasma as a way to identify the solidarity with the whole human race in the person of Adam. In the same context, he describes the motivation for creation by linking Gen 1:26 with the allusions to the predestination and foreknowledge of God in Eph 1:11-12 and 1 Pet $1: 2$, which envisions that the creation of humanity is a highly calculated divine decision. In AH 5.6.1, he conflates Gen 1:26 and Gen 2:7 to argue that the plasma of Adam's formation is the substance moulded after the image of God. He also conflates Gen 1:26 with Rom 8:29 to describe the anthropological activity of the Spirit. The "perfect" or "spiritual" person $(1$ Cor $2: 6,15)$ is not the man formed in Gen 1-2, but the person described in 1 Thess 5:23 comprising body, soul, and Spirit. Irenaeus also derives intertextual references from his Christology and the nature of the relationship between the Word of God and the Father. In AH 4.14.1, the common glorification reflected in John 17:5 is a means to interpret the motivation for God's creative acts in Gen 1-2. The Creator-creature distinction established in Gen 2:7 communicates the sufficiency of the Creator and the need for humanity to be glorified by the Father. This is also exemplified by a series of conceptually and linguistically connected texts including: John 17:24, Isa 43:5-7, and Matt 24:28. In $A H$ 4.33.4, he also conflates Isa 7:14, John 1:14, Gen 1:26 and Gen 2:7 to describe the

\footnotetext{
${ }^{27}$ Psalm 148:5-6 LXX.
} 
salvific nature of the Incarnation and argues that Christ must be greater than David, Solomon, Jonah, and even the evil one who subdued humanity (Matt 12:41-42, Matt 22:43, Matt 12:29), because humankind was formed in his image (Gen 1:26). Finally, the "descending" (descendere) and "ascending" (ascendere) imagery in AH 3.19.3 binds the Incarnation and the ascension though linking Isa 7:11, Luke 15:4-6, and Eph 4:910. The object of salvation in each case is man formed from the dust of the earth (Gen 2:7).

The performance of Gen 1-3 in Irenaeus' eschatology focuses on his reading of Gen 2:2-3, and his understanding of the hallowed seventh day of creation. In $A H$ 4.16.1, the completion of creation in Gen 2:2-3 is a sign (Exod 20:12, Exod 31:13) that anticipates the expectation of God's people eternally dwelling in God's presence (Matt 6:19, Rom 8:36). He extends this eschatological vision in $A H 5.30 .4$ and $A H$ 5.33.1-4 with descriptions of the restoration of the faithful sitting at the table of the Lord in Matt 8:11 and enjoying life in a restored creation (Gen 27:27-29, Matt 13:38, Luke 14:12-13, and Matt 19:29). In the same context, the passages of Isa 11:6-9 and Isa 65:25 describe the restoration of creation to its original subjection in Gen 1:2730 , although the future kingdom will be even more fruitful and plentiful than the original creation. The same eschatological intertextual weaving returns in AH 5.36.3, where Irenaeus connects a network of citations depicting the eschatological kingdom of God.

Alongside his general theological reflections, Irenaeus imagines a series of typological relationships with the characters of Gen 1-3 including: Adam-Christ, Adam-Jonah, Adam-Cain, and Eve-Mary typology. First of all, the Adam-Cain typology in $A H$ 3.23.4-5 serves as the centerpiece of a larger chiasm in AH 3.23.1-8, and Irenaeus contrasts the response of Cain to God, with the response of Adam. While Cain was insolent before God, Adam was contrite, and Adam's contrition is aptly described as the proper fear of God in Prov 1:7.

Second, in AH 3.20.1 Irenaeus follows an Adam-Jonah typology and, following the "sign of Jonah" in Matt 12:39-40, reads the account of Jonah in light of the events of the Garden and 1 Cor 1:29. He specifically links Jonah 1:9, Jonah 2:1-2, and Jonah 3:1, 8-9, with an allusion to the disobedience of Adam and Eve in Gen 3:5-8. He imagines Satan as the "great whale" (magna ceto), who overpowered the first couple in the Garden by means of a carefully calculated deception. But just as Jonah 
received an unexpected salvation from the belly of the whale, so also did Adam receive an unexpected salvation from sin and death.

Third, the most extensive and consistent typological relationship continues to be the Adam-Christ typology. The Pauline analogy contributes a framework that Irenaeus extends and expands with a variety of intertextual references. A general Adam-Christ typology in AH 3.18.1 binds together Gen 2:7 and John 1:14, and these theological connections are supported by Eph 1:10 and Deut 32:4. The same theological perspective harmonizes Gen 2:5 with Rom 5:12, 19. In AH 5.1.1-3, Irenaeus also interprets the Incarnation in Luke 1:35 in a typological relationship with the formation of Adam in Gen 2:7. In AH 5.2.1, Irenaeus argues that though Satan had taken God's creatures captive (Gen 3:1-6), Christ came to retrieve "his own" (ipsum) creation (Gen 2:7, John 1:11), which is the ancient plasma of Adam, and redeem it by his own flesh and blood (Eph 1:7, 1 Tim 2:6). The Adam-Christ typology surfaces again in $A H$ 5.16.2 where he links Gen 1:26 with the incarnation in John 1:14 and a discussion of the passion in Gen 3:6 with Phil 2:8 to describe how the first Adam's disobedience in Gen 3:6 is overturned by the second Adam's obedience in Phil 2:8. In AH 5.21.1-2, he draws together Gen 3:15 with Gal 3:19 and Gal 4:4, so that the protoevangelium is presented as a prophecy through which he views the birth of Christ and the vanquishing of Satan. In addition, the vanquishing of Satan is linked with the first temptation of Matt 4:2-10. Just as Adam was deceived though eating in Gen 3:6, now Christ, even in a state of hunger, vanquished the same enemy by abstaining from eating in Matt 4:3.

The Eve-Mary typology is the last typological relationship that guides Irenaeus reading of Gen 1-3. In AH 3.22.1 he interprets the actions of Eve in correspondence to those of Mary. Whereas Eve becomes the cause of death in Gen 3:6, Mary is the cause of salvation and resurrection in Luke 1:38, Heb 5:9, and Eph 4:16/Col 2:19. Extending his analysis of Gen 3:15 and Gal 4:4 in AH 5.21.1-2, the notion of being born of a woman overturns the nature and function of Eve in the Garden. Just as Eve was taken out of Adam and Satan deceived Adam by means of this woman, so also Christ was born of a woman so that he might vanquish the same enemy who snared Adam. 


\subsubsection{Narratival or Canonical Arrangement}

Irenaeus coordinates texts in a narratival or chronological relationship. In most cases, there is no substantive commentary on these texts, Irenaeus simply arranges scriptural allusions to depict the continuity of salvation history. In AH 2.30.7, Irenaeus also understands the "spiritual mysteries" (sacramenta... spiritalia) that Paul witnessed while raptured to paradise in 2 Cor 12:4 as the "operations of God" (Dei operationes), which he defines as the creative acts of God in Gen 1:1, Gen 2:7, and Gen 2:15. In $A H$ 2.30.9, Irenaeus describes the nature of God and God's economic activity using Gen 2:7 and Gen 2:8 to frame certain events of salvation history including allusions to Noah, Abraham, Isaac, Jacob, the Law, Prophets, and Christ. In AH 3.3.3, he provides another telescoped summary of salvation history and in $A H 3.11 .8$ summarizes the covenantal structure of scripture beginning with a reference to the Adamic Covenant. In AH 4.6.2, he reads a summary of the acts of God in succession beginning with allusions to Gen 1:26, Gen 2:7, and Gen 1:28. Finally, in $A H 4.11 .2$ Irenaeus reads Gen 1:28 as a paradigm for human growth that is realized in the unfolding of salvation history.

He also presents canonical arrangements of texts that intentionally links texts from the prophets, Gospels and apostolic writings. The unification of these disparate portions of scripture demonstrates, for Irenaeus, the continuity of the work of God from creation to glorification. As we mentioned earlier, this argument is found in $A H$ 2.2.5. Similarly, in $A H$ 4.16.1, he provides an eschatological reading of Gen 2:2-3 that links Exod 20:12, Exod 31:13, Matt 6:19, and Rom 8:36, and in AH 4.20.1 he links Mal 2:10, Matt 11:27, and Eph 4:6.

\subsubsection{General-to-Particular}

Finally, Irenaeus uses the classical general-to-particular style of argumentation. In AH 1.22.1 and AH 4.20.1-4 he binds general allusions to Psalm 32:6 LXX, John 1:3, Col 1:16, and Mand 1.1 through the linking terms of "all things" (omnia), and contrasts these general references with the particular creation of humankind in Gen 1:26 and Gen 2:7. In $A H$ 5.8.1 he contrasts the Spirit as a pledge given specifically to the faithful (Eph 1:14, Rom 8:9,15) with the fullness of the Spirit given in the final consummation (Gen 1:26, 1 Cor 13:12). Then, in AH 5.12.2, he develops the contrasts the breath in Gen 2:7 and the Spirit in 1 Cor 15:45 with allusions to Isa 42:5 and Isa 
57:16. Both of these passages confirm the universality of the breath given to all in creation and the particularity of the Spirit given to the faithful.

\subsection{Conclusion}

When Irenaeus turns to Gen 1-3, he reads these texts in harmony and continuity with the rest of scripture. He is never concerned with reading particular texts in isolation and explicitly challenges his opponents with a reading of Moses that is in continuity with the apostolic teaching. ${ }^{28}$ This view unifies God's creative intentions with the economic unfolding of salvation history. Irenaeus is certainly a "consistent creationist," to cite the label of Steenberg, but he is also a consistent exegete who reads creation texts within the context of salvation history and articulates his theological vision by means of the careful integration of texts. ${ }^{29}$ In Irenaeus' words the "proofs in the Scriptures cannot be proven except from the Scriptures themselves" (ostensiones quae sunt in Scripturis non possunt ostendi nisi ex ipsis Scripturis).$^{30}$ We have found that, for Irenaeus, Gen 1-3 is a pivotal piece within a larger exegetical and theological mosaic of texts. As a result, this study also reveals the need for fresh analysis of the intertextual performance of scripture in Irenaeus. In doing so, we will continue to see how texts, such as the opening pages of Genesis, are carefully crafted into his theological vision that intentionally unites the diverse utterances of scripture so that "there will be heard one harmonious melody in us, praising in hymns the God who created all things." (unam consonantem melodiam in nobis sentiet, laudantem hymnis Deum qui fecit omnia). ${ }^{31}$

\footnotetext{
${ }^{28}$ AH 2.2.5.

${ }^{29}$ Steenberg, Irenaeus, 2, 9; cf. Smith, “Chiliasm ," 320.

${ }^{30}$ AH 3.12.9.

${ }^{31}$ AH 2.28.3.
} 
APPENDIX

GENESIS 1-3 AND RELATED INTERTEXTS IN AH 1-5

\begin{tabular}{|c|c|c|c|}
\hline 1 & 1.5.1-6 & Gen 2:5, Gen 2:7 & 1 Cor $15: 47$ \\
\hline 2 & 1.9 .3 & Gen 2:7 & John 1:14 \\
\hline 3 & 1.14 .6 & Gen 1:31 & Matt 17:1, Matt 27:45, John 19:14 \\
\hline 4 & $\begin{array}{l}1.18 .1- \\
4\end{array}$ & $\begin{array}{l}\text { Gen } 1: 2 \text {, Gen } 1: 3-12 \text {, Gen } \\
1: 14-27 \text {, Gen } 1: 26 \text {, Gen } \\
2: 10\end{array}$ & Exod 26:1/36:8, Exod 28:17, 1 Cor 15:46-7 \\
\hline 5 & 1.22 .1 & Gen 1:1, Gen 2:7 & $\begin{array}{l}\text { Psalm 32:6 LXX, John 1:3, Col 1:16, } 2 \text { Cor 4:18, } \\
\text { Exod 3:6, Matt 22:32, Eph 1:3, Mand 1 }\end{array}$ \\
\hline 6 & $\begin{array}{l}1.24 .1- \\
2\end{array}$ & $\begin{array}{l}\text { Gen 1:26, Gen 2:7, Gen } \\
3: 19\end{array}$ & \\
\hline 7 & 1.28 .1 & Gen 1:27-28 & \\
\hline 8 & $\begin{array}{l}1.30 .1- \\
9\end{array}$ & $\begin{array}{l}\text { Gen } 1: 2 \text {, Gen } 1: 7-8 \text {, Gen } \\
1: 26 \text {, Gen } 2: 7, \text { Gen } 2: 16 \text {, } \\
\text { Gen } 2: 22 \text {, Gen } 3: 1-7 \text {, Gen } \\
3: 20 \text {, Gen } 3: 23\end{array}$ & Isa 45:5-6/46:9, Eph 1:21 \\
\hline 9 & 2.2 .5 & Gen 1:1, Gen 1:3 & John 1:3, Psalm 33:9/148:5 LXX, Heb 3:5 \\
\hline 10 & 2.26 .1 & Gen 2:7 & John $15: 9-10,1$ Cor $2: 2,1$ Cor $8: 1$ \\
\hline 11 & 2.28 .1 & Gen 1:1, Gen 2:7, Gen 1:28 & Matt 3:12, Heb 7:7 \\
\hline 12 & 2.30 .7 & Gen 1:1, Gen 2:7, Gen 2:15 & 2 Cor $12: 2-4$ \\
\hline 13 & 2.30 .9 & Gen 1:1, Gen 2:7, Gen 2:8 & Eph 1:21, Matt 11:27, Heb 1:3. Mand 1 \\
\hline 14 & $\begin{array}{l}2.34 .3- \\
4 \\
\end{array}$ & Gen 2:1, Gen 2:7 & $\begin{array}{l}\text { Psalm 148:5-6/32:9 LXX, Psalm 20:5 LXX, } \\
\text { Luke 16:10 }\end{array}$ \\
\hline 15 & 3.3 .3 & Gen 1:1, Gen 2:7 & $\begin{array}{l}\text { Gen 6:17, Gen 12:1, Exod 3:10, Exod 3:4, Exod } \\
\text { 20:1, Isa 6:8, Matt 25:41 }\end{array}$ \\
\hline 16 & 3.11 .5 & $\begin{array}{l}\text { Gen 1:1, Gen 1:9, Gen 1:11, } \\
\text { Gen 2:6 }\end{array}$ & $\begin{array}{l}\text { John 1:18, John 2:1, John 2:10, John 6:55, Matt } \\
\text { 22:2-10 }\end{array}$ \\
\hline 17 & 3.11 .8 & Gen 2:16-17 & Gen 9:8-16, Exod 19-20, Eph 1:10 \\
\hline 18 & 3.18 .1 & Gen 1:26, Gen 2:7 & John $1: 14$ \\
\hline 19 & 3.18 .7 & Gen 2:5 & Rom 5:12, Rom 5:19, Rom 6:20-21 \\
\hline 20 & 3.19 .3 & Gen 2:7 & $\begin{array}{l}\text { Isa 7:11, Isa 7:12, Isa 7:14, John 14:2, Eph 4:9- } \\
\text { 10, Luke } 15: 4-6,1 \text { Cor } 15: 20\end{array}$ \\
\hline 21 & 3.20 .1 & Gen 3:1-8 & $\begin{array}{l}\text { Jonah 1:9, Jonah 2:1, Jonah 2:2, Jonah 3:1, } \\
\text { Jonah 3:8-9, Matt 12:39-40, } 1 \text { Cor 12:9 }\end{array}$ \\
\hline 22 & 3.21 .10 & Gen 1:26, Gen 2:5, Gen 2:7 & John 1:3, Rom 5:12, Rom 5:19, 1 Cor 15:45, 47 \\
\hline 23 & 3.22 .1 & Gen 1:26, Gen 2:7 & John 1:3, Matt 5:5, Rom 1:3-4, Gal 4:4 \\
\hline 24 & $\begin{array}{l}3.22 .2- \\
3\end{array}$ & Gen 2:7 & $\begin{array}{l}\text { Psalm 68:27 LXX, Matt 4:2, Matt 26:38, Luke } \\
\text { 22:44, Luke 4:6, John 11:35, John 19:34 }\end{array}$ \\
\hline 25 & 3.22 .4 & $\begin{array}{l}\text { Gen 1:28, Gen 2:25, Gen } \\
3: 6\end{array}$ & $\begin{array}{l}\text { Deut 22:23-24, Psalm 44:17 LXX, Matt 19:30, } \\
\text { Matt 20:16, Luke 1:38, Luke 3:23-38, Col 1:18, } \\
\text { Heb 5:9 }\end{array}$ \\
\hline 26 & 3.23 .1 & Gen 1:26, Gen 3:5 & $\begin{array}{l}\text { Matt 12:29, Luke 15:47, Luke 19:10, Acts 1:7, } 1 \\
\text { Cor 15:47, Eph 1:5, 9, } 2 \text { Tim 1:10 }\end{array}$ \\
\hline 27 & 3.23 .2 & Gen 1:26 & Matt 12:29/Luke 11:21-22 \\
\hline 28 & 3.23 .3 & Gen 3:14, Gen 3:16, Gen & Matt 25:41 \\
\hline
\end{tabular}




\begin{tabular}{|c|c|c|c|}
\hline & & 3:17-19 & \\
\hline 29 & 3.23 .4 & $\begin{array}{l}\text { Gen 4:7-8, Gen 4:9, Gen } \\
4: 11\end{array}$ & Matt 23:35 \\
\hline 30 & 3.23 .5 & $\begin{array}{l}\text { Gen } 3: 7, \text { Gen } 3: 8 \text {, Gen 3:10, } \\
\text { Gen 3:13, Gen 3:21 }\end{array}$ & Prov 1:7 \\
\hline 31 & 3.23 .6 & Gen 3:23-24 & Rom 6:2,10 \\
\hline 32 & 3.23 .7 & Gen 3:15 & $\begin{array}{l}\text { Psalm 90:13 LXX, Luke 10:19, Rom 5:12,17, } \\
\text { 1Cor 15:26, } 1 \text { Cor 15:54-55, Gal 3:16, Gal 3:19, } \\
\text { Rev 20:2/12:9 }\end{array}$ \\
\hline 33 & 3.23 .8 & Gen 3:5 & $\begin{array}{l}\text { Matt 18:12-14/Luke 15:4-7, } 1 \text { Cor 15:22, Rom } \\
\text { 5:20 }\end{array}$ \\
\hline 34 & 3.24 .1 & Gen 2:7 & $\begin{array}{l}\text { Gen } 28: 12 \text {, Jer } 2: 13 \text {, John } 4: 10 \text {, John 7:37-38, } \\
\text { Matt 7:7/Luke 11:9, Matt 7:24-27, } 1 \text { Cor 12:11, } \\
\text { 1 Cor 12:28, Eph 1:14, Eph 3:19, Col 2:7, } 1 \text { John } \\
\text { 5:6, Rev 22:1 }\end{array}$ \\
\hline 35 & 3.24 .2 & $\begin{array}{l}\text { Gen 1:26, Gen 1:28, Gen } \\
2: 7\end{array}$ & Psalm 32:6 LXX, Prov 8:30 \\
\hline 36 & $\begin{array}{l}4 . p f .3- \\
4\end{array}$ & $\begin{array}{l}\text { Gen } 1: 26 \text {, Gen } 2: 7, \text { Gen } \\
3: 1-5\end{array}$ & Luke $1: 2,2$ Cor $11: 3,2$ Tim 2:23 \\
\hline 37 & 4.6 .2 & $\begin{array}{l}\text { Gen 1:26, Gen 1:28, Gen } \\
2: 7\end{array}$ & John 5:31, Eph 1:10 \\
\hline 38 & 4.10 .1 & Gen 3:9 & John 5:39-40, John 5:46 \\
\hline 39 & $\begin{array}{l}4.11 .1- \\
2\end{array}$ & Gen 1:28 & Matt 13:17, Matt 25:21/19:17 \\
\hline 40 & 4.14 .1 & Gen 2:7 & $\begin{array}{l}\text { Isa 43:5, Matt 24:28, John 8:58, John 15:16, } \\
\text { John 17:5, John 17:24 }\end{array}$ \\
\hline 41 & 4.16 .1 & Gen 2:2-3 & Exod 20:12, Exod 31:13, Matt 6:19, Rom 8:36 \\
\hline 42 & $\begin{array}{l}4.20 .1- \\
4\end{array}$ & Gen 1:26, Gen 2:7 & $\begin{array}{l}\text { Prov } 3: 19-20, \text { Prov 8:22-25, Prov 8:27-31, Mal } \\
\text { 2:10, Matt 11:27, John 1:14, Acts 10:42, Eph } \\
\text { 4:6, Col 1:18, } 1 \text { Pet } 2: 22, \operatorname{Rev} 3: 7, \operatorname{Rev} 5: 3 \text {, Rev } \\
\text { 5:9, Rev 5:12, Mand } 1\end{array}$ \\
\hline 43 & 4.32 .1 & Gen 1:3 & John 1:3, Eph 4:5-6, Eph 4:15-16, Col 2:19 \\
\hline 44 & 4.33 .4 & Gen 1:26, Gen 2:7 & $\begin{array}{l}\text { Isa 7:14, Matt 12:41-42, Matt 22:29, Matt } \\
22: 43,1 \text { Cor } 2: 15\end{array}$ \\
\hline 45 & 4.34 .4 & Gen 2:7 & Isa 2:3-4, Isa 57:1, Matt 5:39, John 4:37 \\
\hline 46 & $\begin{array}{l}4.36 .2- \\
6\end{array}$ & Gen 2:7 & $\begin{array}{l}\text { Gen 6:2-5, Psalm 23:1 LXX, Matt 5:45, Matt } \\
\text { 21:33-43, Matt 22:7, Rom 13:1-6 }\end{array}$ \\
\hline 47 & 4.37 .4 & Gen 1:26 & $\begin{array}{l}1 \text { Cor } 6: 11,1 \text { Cor } 6: 12 \text {, Eph 4:25, Eph 4:29, Eph } \\
5: 8,1 \text { Pet } 2: 16\end{array}$ \\
\hline 48 & $\begin{array}{l}4.38 .1- \\
2\end{array}$ & Gen 2:7 & 1 Cor 3:2-3, Heb 5:12-14 \\
\hline 49 & 4.38 .3 & $\begin{array}{l}\text { Gen 1:26, Gen 1:28, Gen } \\
2: 7\end{array}$ & Wis 6:19 \\
\hline 50 & 4.38 .4 & Gen 1:26, Gen 3:5 & Psalm 82:6-7 LXX, 1 Cor 15:53 \\
\hline 51 & 4.39 .2 & Gen 2:5, Gen 2:7 & Exod 25:11, Psalm 44:12 LXX \\
\hline 52 & 4.40 .3 & Gen 3:15 & $\begin{array}{l}\text { Matt 13:24-25, Matt 13:38-43, Matt 25:41, Gal } \\
4: 4\end{array}$ \\
\hline 53 & $5.1 .1-3$ & $\begin{array}{l}\text { Gen } 1: 26 \text {, Gen } 2: 7, \text { Gen } \\
3: 1-6 \text {, Gen } 3: 24\end{array}$ & Luke 1:35, John 1:13, 1 Cor 5:7, 1 Cor $15: 22$ \\
\hline
\end{tabular}




\begin{tabular}{|c|c|c|c|}
\hline 54 & 5.2 .1 & Gen 1:26 & John 1:11, Rom 11:35, Eph 1:7 \\
\hline 55 & $5.3 .2-3$ & Gen 2:7 & 1 Cor $15: 53-54,2$ Cor $12: 9$, Heb 11:19 \\
\hline 56 & $5.5 .1-2$ & $\begin{array}{l}\text { Gen } 2: 7, \text { Gen } 2: 8, \text { Gen 2:15, } \\
\text { Gen 3:23-24 }\end{array}$ & $\begin{array}{l}\text { Gen 5:24, } 2 \text { Kings 2:11, Dan 3:19, Jonah 2, } 2 \\
\text { Cor 12:4 }\end{array}$ \\
\hline 57 & 5.6 .1 & Gen 1:26, Gen 2:7 & Rom $8: 29,1$ Cor $2: 6,15,1$ Thes $5: 23$ \\
\hline 58 & 5.7.1-2 & Gen 2:7, Gen 3:19 & $\begin{array}{l}\text { Rom 8:11, Psalm 22:31 LXX, John 20:20, } 1 \text { Cor } \\
6: 14,1 \text { Cor } 15: 36,42-44,1 \text { Cor } 8: 9,12,1 \text { Pet } 1: 8 \\
1 \text { Cor } 13: 9,12\end{array}$ \\
\hline 59 & 5.8 .1 & Gen 1:26 & Rom 8:9,15, 1 Cor 15:53, Eph 1:13-14 \\
\hline 60 & 5.10 .1 & Gen 1:26, Gen 2:15 & $\begin{array}{l}\text { Matt 7:9, Matt 13:25, Rom 11:17, } 1 \text { Cor 15:50, } \\
\text { James 1:21 }\end{array}$ \\
\hline 61 & 5.11 .2 & Gen 1:26, Gen 2:7 & 1 Cor $6: 11,1$ Cor $15: 49-50$, Gal 5:19 \\
\hline 62 & $\begin{array}{l}5.12 .2- \\
6\end{array}$ & Gen 2:7 & $\begin{array}{l}\text { Isa } 42: 5 \text {, Isa } 57: 16 \text {, Acts } 2: 17,1 \text { Cor } 15: 45-46 \text {, } \\
\text { Gal 1:15-16 }\end{array}$ \\
\hline 63 & $\begin{array}{l}5.14 .1- \\
2\end{array}$ & Gen 2:7 & $\begin{array}{l}\text { Gen } 4: 10 \text {, Gen } 9: 5-6 \text {, Matt 23:35-36, Luke 19:10, } \\
\text { John 1:14, } 1 \text { Cor } 15: 50 \text {, Col 1:22 }\end{array}$ \\
\hline 64 & 5.15 .2 & Gen 2:7 & John 5:14, John 9:3,6, Luke 15:4-6, Luke 19:10 \\
\hline 65 & 5.15 .3 & Gen 2:7 & Jer 1:15, John 9:3,7, Gal 1:15, Titus 3:5 \\
\hline 66 & 5.15 .4 & $\begin{array}{l}\text { Gen } 1: 26 \text {, Gen } 2: 7, \text { Gen } \\
3: 8-9\end{array}$ & John 9:3, 7 \\
\hline 67 & 5.16 .1 & $\begin{array}{l}\text { Gen 1:26, Gen 2:7, Gen } \\
3: 19\end{array}$ & \\
\hline 68 & 5.16 .2 & Gen 1:26, Gen 2:7, Gen 3:6 & John 1:14, Phil 2:8 \\
\hline 69 & 5.16 .3 & Gen 2:17, Gen 3:6 & \\
\hline 70 & $\begin{array}{l}5.17 .1- \\
2\end{array}$ & Gen 2:17, Gen 3:8 & $\begin{array}{l}\text { 1Tim 2:5, Matt 6:9,12, Matt 9:2/Luke 5:20, } \\
\text { Luke 1:78 }\end{array}$ \\
\hline 71 & $\begin{array}{l}5.17 .3- \\
4\end{array}$ & Gen 3:6 & $\begin{array}{l}\text { Luke 5:21, Matt 6:12, Psalm 31:1-2 LXX, Col } \\
\text { 2:14, } 2 \text { Kings 6:1-7, Matt 3:10, Jer 23:29, Eph } \\
\text { 3:18, Isa 11:12, Eph 4:6 }\end{array}$ \\
\hline 72 & 5.19 .1 & Gen 3:1-8 & Matt 10:16, Luke 1:30-35 \\
\hline 73 & 5.20 .2 & $\begin{array}{l}\text { Gen } 2: 8, \text { Gen } 2: 16 \text {, Gen } \\
2: 17\end{array}$ & Matt 15:14, 2 Tim 3:7, Rom 12:3, Eph 1:10 \\
\hline 74 & $\begin{array}{l}5.21 .1- \\
3 \\
\end{array}$ & $\begin{array}{l}\text { Gen 1:26, Gen 2:7, Gen 3:6, } \\
\text { Gen 3:15 }\end{array}$ & Matt 4:2-10, Luke 4:6-7, Gal 3:19, Gal 4:4 \\
\hline 75 & $\begin{array}{l}5.23 .1- \\
2\end{array}$ & $\begin{array}{l}\text { Gen 1:5, Gen 2:16-17, Gen } \\
3: 1-5\end{array}$ & Gen 5:5, Psalm 89:4 LXX, John 8:44, Eph 1:10 \\
\hline 76 & 5.26 .2 & Gen 3:1-6 & Matt 25:41 \\
\hline 77 & $\begin{array}{l}5.28 .3- \\
4\end{array}$ & $\begin{array}{l}\text { Gen } 1: 26 \text {, Gen } 2: 1-2 \text {, Gen } \\
2: 7\end{array}$ & $\begin{array}{l}\text { Psalm 89:4 LXX, Matt 3:12, Rev 13:18, } \\
\text { Ignatius, Rom 4.1 }\end{array}$ \\
\hline 78 & 5.30 .4 & Gen 2:2-3 & Matt 8:11, Matt 16:27, Rev 19:20 \\
\hline 79 & $\begin{array}{l}5.33 .1- \\
4\end{array}$ & $\begin{array}{l}\text { Gen 1:27-28, Gen 1:30, } \\
\text { Gen 2:2-3 }\end{array}$ & $\begin{array}{l}\text { Gen 27:27-29, Isa 11:6-9, Isa 65:25, Psalm } \\
\text { 103:30 LXX, Matt 19:29, Luke 14:12-13, Papias }\end{array}$ \\
\hline 80 & 5.34 .2 & Gen 3:6 & Gen 9:27, Isa 30:25-26, Isa 58:14 \\
\hline 81 & 5.36 .3 & $\begin{array}{l}\text { Gen } 1: 26 \text {, Gen 1:31-2:1, } \\
\text { Gen 2:2-3, Gen 2:7 }\end{array}$ & $\begin{array}{l}\text { Psalm 131:14/Psalm118:20 LXX, Matt 26:29, } \\
\text { John 5:25, 28-29, Rom 8:19-21, } 1 \text { Cor 2:9, } 1 \text { Pet } \\
\text { 1:12, Rev 20:5 }\end{array}$ \\
\hline
\end{tabular}




\section{BIBLIOGRAPHY}

\section{Primary Sources}

The Apostolic Fathers. LCL 24-25. Translated by B. Ehrman. Cambridge, MA: Harvard University Press, 2003.

Behr, J. On the Apostolic Preaching. Crestwood, NY: St. Vladimir's Seminary Press, 1997.

Evans, E. Tertullian Adversus Marcionem. Oxford: Clarendon Press, 1972.

Grant, R. M. Irenaeus of Lyons. New York: Routledge, 1997.

Theophilus of Antioch: To Autolycus. Oxford: Clarendon Press, 1970.

MacKenzie, I. Irenaeus's Demonstration of the Apostolic Preaching: A Theological Commentary and Translation. Burlington, VT: Ashgate, 2002.

Marcovich, M. Apologies: Iustini Martyris Apologiae pro Christianis. Berlin: De Gruyter, 1994.

- Dialogue with Trypho the Jew: Iustini martyris dialogues com Trophone. Berlin: De Gruyter, 1997.

Roberts, A., and J. Donaldson. Ante-Nicene Fathers. Vol. 1. Peabody, MA: Hendrickson, 1994.

Robinson, J. A. St. Irenaeus: The Demonstration of the Apostolic Preaching. London: SPCK, 1920.

Rousseau, A (et al.) Contre les hérésies, Livre 1. 2 vols. Sources Chrétiennes, nos. 263-64. Paris: Éditions du Cerf, 1979.

. Contre les hérésies, Livre II. 2 vols. SC 293, 294. Paris: Éditions du Cerf, 1982.

- Contre les hérésies, Livre III. 2 vols. SC 210, 211. Paris: Éditions du Cerf, 1974.

. Contre les hérésies, Livre IV. 2 vols. SC 100, 2 vols. Paris: Éditions du Cerf, 1965.

. Contre les hérésies, Livre V. 2 vols. SC 152, 153. Paris: Éditions du Cerf, 1969.

The Démonstration de la Prédication Apostolique. SC 406. Paris: Éditions du Cerf, 1995.

Smith, J. P. St. Irenaeus: Proof of the Apostolic Preaching. ACW 16. New York: Newman, 1952.

Unger, D. J., and J. J. Dillon. St Irenaeus of Lyons, Against the Heresies: Book 1. New York: 
Paulist Press, 1992.

\section{Secondary Sources}

Abadía, J. P. T. Cristo y el universo: Estudio linguístico y themático de Ef 1:10h en Efesios y en la obra de Ireneo de Lyon. Salamanca: Universidad Pontificia, 1995.

Abramowski, L. "Irenaeus, Adv Haer III 3,2: ecclesia Romana and omnis ecclesia; and ibid 3,3: Anacletus of Rome." JTS 28 (1977): 101-104.

Alkier, S. "Intertextuality and the Semiotics of Biblical Texts." In Reading the Bible Intertextuality, 1-21. Edited by Richard B. Hays, Stefan Alkier, and Leroy A. Huizenga. Waco, TX: Baylor University Press, 2009.

- "New Testament Studies on the Basis of Categorical Semiotics." In Reading the Bible Intertextuality. eds. Richard B. Hays, Stefan Alkier, and Leroy A. Huizenga, 223-248. Waco, TX: Baylor University Press, 2009.

Allenbach, J. (et. al.). Biblia Patristica: Index Des Citations Et Allusions Bibliques Dans La Littérature Patristique. Vol. 1. Paris: Editions du Centre National de la Recherche Scientifique, 1975.

Altermath, F. "The Purpose of the Incarnation according to Irenaeus." StuPat 13 (1971): 63-8.

Anderson, G. A. The Genesis of Perfection: Adam and Eve in Jewish and Christian Imagination. Louisville, KY: Westminster John Knox Press, 2001.

Anderson, R. Ancient Rhetorical Theory and Paul. Louvain: Kok Pharos, 1996.

Andresen, C. "Zur Entstehung und Geschichte des trinitarischen Personbegriffes." ZNW 52 (1961) 1-39.

Armstrong, G. T. Die Genesis in der Alten Kirche: Die drei Kirchenväter. Tübigen: Mohr Siebeck, 1962.

Aubineau, M. “Incorruptibilite at divinization selon saint Irénée.” RSR, 44.1 (1956): $25-52$.

Ayres, L. Nicaea and Its Legacy: An Approach to Fourth Century Trinitarian Theology. Oxford: Oxford University Press, 2006.

."The soul and the reading of scripture: a note on Henri de Lubac." SJT 61.2 (2008): 173-90.

Bacq, P. De l'ancienne à la nouvelle alliance selon s. Irénée: unité du livre IV de l'Adversus Haereses. Paris: Editions Lethielleux, 1978. 
Balás, D. “The Use and Interpretation of Paul in Irenaeus's Five Books Adversus Haereses." SecCen 9 (1992): 27-39.

Balthasar, H. U. von. Scandal of The Incarnation: Irenaeus Against the Heresies. San Francisco: Ignatius Press, 1981.

Barnard, L. W. "The Old Testament and Judaism in the Writings of Justin Martyr." VT 14.4 (1964): 395-406.

Barr, J. "The Image of God in the Book of Genesis - A study of terminology." BJRL 51.1 (1968): 11-26.

“Jewish apocalyptic in recent scholarly study." BJRL 58, no.1 (1975): 9-35.

Barthes, R. "From Word to Text." In Image - Music - Text. Edited by S. Heath. Glasgow: Fontana, 1977.

Barthoulot, J. “Traduction integral de la Démonstration de la Predication Apostolique." RSR 6 (1916): 368-432.

Basevi, C. "La generazoine eternal di Cristo nei Ps 2 e 109 secondo S. Giustino e S. Ireneo.” Aug 22.1-2 (1982): 135-47.

Bavaud, G. "Saint Irénée, docteur de l'Immaculée Conception de Marie." In Virgo liber Verbi, 121-131. Rome: Marianum, 1991.

Bauer, W. Orthodoxy and Heresy in Earliest Christianity. London: SCM, 1972.

Beal, T. K. "Intertextuality." In Handbook of Postmodern Biblical Interpretation, 128-130. Edited by A. K. A. Adam. St Louis: Chalice, 2000.

Beattie, T. "Mary in Patristic Thought." In Mary: The Complete Resource, 75-105. Edited by S. J. Boss. Oxford: Oxford University Press, 2007.

Behr, J. “Irenaeus AH 3.23.5, and the Ascetic ideal.” SVTQ 36. 4 (1993): 309-10.

. "Scripture, the Gospel, and Orthodoxy." SVTQ 43.3-4 (1999): 223-48.

. "The Word of God in the Second Century." ProEc 9.1 (2000): 85-107.

- Asceticism and Anthropology in Irenaeus and Clement. Oxford: Oxford University Press, 2000.

The Way to Nicaea. New York: St. Vladimir's Seminary Press, 2001.

Bellinzoni, A. "The Gospel of Matthew in the Second Century." SecCen 9.4 (1992): 217-54. 
. "The Gospel of Luke in the Second Century." In Literary Studies in LukeActs, 59-76. Edited by R. E. Thompson and T. E. Phillips. Macon, GA: Mercer University Press, 1998.

Benoît, A. Saint Irénée: introduction à l'étude de sa théologie. Paris: Presses universitaires de France, 1960.

Bentivegna, J. "Pauline Elements in the Anthropology of St. Irenaeus." StuEv 5 (1968): 229-33.

Beuzart, P. Essai sur la Théologie d' Irénée. Paris: Leroux, 1908.

Bilde, P. "Gnosticism, Jewish Apocalypticism, and Early Christianity." In In the last days: On Jewish and Christian Apocalyptic and its period, 9-32. Edited by Jeppesen (et al.). Aarhus: Arhus University Press, 1994.

Bingham D. J. Irenaeus' use of Matthew's Gospel in Adversus Haereses. Leuven: Peeters, 1998.

. "Hope in Irenaeus of Lyons." ETL 76.4 (2000): 265-82.

. "Irenaeus reads Romans 8: Ressurection and Renovation." In Early Patristic Readings of Romans, 114-32. Edited by K. Gaca and L. L. Welborn. New York: T\&T Clark, 2005.

_. "Knowledge and love in Irenaeus of Lyons." StuPat 36 (2001): 184-199.

"Irenaeus and Hebrews." In Christology and Hermeneutics of Hebrews: Profiles from the History of Interpretation. Edited by J. Laansma and D. Treier. New York: Continuum, forthcoming.

. "Irenaeus on Gnostic Biblical Interpretation." StuPat 40 (2006): 367-79.

. "Christianizing Divine Aseity: Irenaeus reads John." In The Gospel of John in Christian Theology, 53-67. Edited by Richard Bauckam and Carl Mosser. Grand Rapids: Eerdmans, 2008.

Blackwell, B. "Paul and Irenaeus." In Paul and the Second Century: The Legacy of Paul's life, Letters, and Teaching, 190-206. Edited by M. Bird and J. Dodson. London: T\&T Clark, 2011.

Blanchard, Y. M. Aux sources de canon, le temoignage d'Irenee. Paris: Cerf, 1993.

Blowers, P. "The Regula Fidei and the Narrative Character of Early Christian Faith." ProE 6, no.2 (1997): 199-228.

Boersma, H. "Irenaeus, Derrida and hospitality: on the eschatological overcoming of violence." MT 19.2 (2003): 163-80. 
Böhlig, A. and C. Markschies. Gnosis und Manichäismus: Forschungen und Studien zu Texten von Valentin und Mani sowie zu den Bibliotheken von Nag Hammadi und Medinet Madi. Berlin: De Gruyter, 1994.

Bonwetsch, N. Die theologie des Irenäus. Gütersloh: C. Bertelsmann, 1925.

Bousset, W. Jüdisch-christlicher Schulbetrieb in Alexandria und Rom: Literarische Untersuchungen zu Philo und Clemens von Alexandria, Justin und Irenäus. Göttingen, 1915.

Kyrios Christos: a history of the belief in Christ from the beginnings of Christianity to Irenaeus. Translated by J. E. Steely. Nashville: Abingdon Press, 1970.

Bouteneff, P. C. Beginnings: Ancient Christian Readings of the Biblical Creation Narratives. Grand Rapids: Baker Academic, 2008.

Boyarin, Daniel. Intertextuality and the Reading of Midrash. Bloomington, IN, Indiana University Press, 1990.

Brown, R. F. “On the Necessary Imperfection of Creation: Irenaeus' Adversus haereses IV, 38." SJT 28.1 (1975): 17-25.

Brox, N. "Irenaeus and the Bible." In Handbook of Patristic Exegesis, Vol 1, 483-506. Edited by Charles Kannengiesser. Brill: Leiden, 2004.

. "Rome and 'jede Kirche' im 2 Jahrhundert: Zu Irenäus, adv. haer. III, 3,2." AHC (1975): 42-78.

Brunner, E. Man in Revolt: A Christian Anthropology. Translated by Olive Wyon. Philadelphia: Westminster Press, 1947.

Bushur, J. G. “'Joining the End to the Beginning' Divine Providence and the Interpretation of Scripture in the Teaching of Irenaeus, Bishop of Lyons." Unpublished dissertation. University of Durham, UK, 2009.

Campenhausen, H. von. "Irenäus und das NT.” ThLBer 90 (1965): 1-8.

Chilton, B. D. "Irenaeus on Isaac." in StuPat $17.2,643-47$. Edited by E.A. Livingstone. Oxford: Pergamon Press, 1982.

Clark, E. "Heresy, Asceticism, Adam and Eve: Interpretation of Genesis 1-3 in the Later Latin Fathers." In Ascetic Piety and Women's Faith: Essays on Late Ancient Christianity, 367-82. Edited by E. Clark. Lewiston, NY: Edwin Mellen Press, 1986.

Reading Renunciation: Asceticism and Scripture in Early Christianity. Princeton: Princeton University Press, 1999. 
Constantelos, J. D. "Irenaeus of Lyons and his Central Views of Human Nature," SVTQ 33.4 (1989): 351-63.

Czesz, B. “La parabola del figlio prodigo (Lc 15, 11-32) in Ireneo.” Aug 17 (1977): 10711.

Daley, B. The Hope of the Early Church: A Handbook of Patristic Eschatology. Cambridge: University Press, 1991.

Daniélou, J. “S. Irénée et les origins de la théologie de l'histore.” RSR 34 (1947): 22731.

Davidson, I. The Birth of the Church: From Jesus to Constantine AD 30-312. Vol. 1. Grand Rapids: Baker Books, 2004.

Dawson, D. Allegorical Readers and Cultural Revision in Ancient Alexandria. Berkeley: University of California Press, 1992.

De Aldama, J. A. “Adam, typus futuri (San Ireneo Advers. Haer. 3.22.3).” SacE 13 (1962): 266-80.

. "La naissance du Seigneur dans l'exégèse patristrique du Ps 21:10s (=22:10a)." RSR 51 (1963): 5-29.

María en la patrística de los siglos I y II. Madrid: Editorial Catholica, 1970.

De Alès, A. “La doctrine de la récapitulationen Saint Irénée.” RSR 6 (1916): 185-211.

De Andia, Y. Homo vivens: Incorruptibilité et divinization de l'homme selon Irénée de Lyon. Paris: Etudes Augustiniennes, 1986.

. "Irénèe théologien de l' unite." NRT 109 (1987): 31-48.

."L'interprétation irénéenne de la beatitude des doux: 'Bienheureux les doux, ils recevront la terre en héritage’ (Mt 5:5).” StuPat 18.3 (1989): 85-102, originally published "La beatitudine dei miti (Mt. V,5) nell'interpretazione di S. Ireneo.” RSLR 20 (1984): 275-86.

"Modèles de l'unité des testaments selon Irénée de Lyon." StuPat 21 (1989): 49-59.

De Andia, Y. and D. L. Schindler, Jr "The 'Science So Falsely Called': Seduction and Separation.” Com 24 (1997): 645-70.

Donovan, M. A. “Irenaeus in Recent Scholarship.” SecCen 4:4 (1984): 219-241. One Right Reading? A Guide to Irenaeus. Collegeville, MN: Liturgical Press, 1997. 
"Alive to the Glory of God: A key Insight in St. Irenaeus." TS 14.2 (1990): 99-112.

Downing, Victor K. "Doctrine of Regeneration in the Second Century." ERT 14.2 (1990): 99-112.

Driscoll, J. "Uncovering the dynamic lex orandi - lex credendi in the baptismal theology of Irenaeus." ProEc, 12.2 (2003): 213-25.

Dunderberg, Ismo. "The School of Valentinus." In A Companion to Second-Century Christian 'Heretics,' 64-99. Edited by A. Marjanen and P. Loumanen. Leiden: Brill, 2005.

Dunning, B. H. "Virgin Earth, Virgin Birth: Creation, Sexual Difference, and Recapitulation in Irenaeus of Lyons.” JR 89.1 (2009): 57-88.

Edwards, M. "Gnostics and Valentinians in the Church Fathers." JTS 40(1) (1989): 2647.

Ehrman, B. The New Testament: A Historical Introduction to the Early Christian Writings. Oxford: Oxford University Press, 2000.

Fantino, J. L'homme, image de Dieu chez saint Irénée de Lyon. Paris: Editions du Cerf, 1986.

—. "La creation ex nihilo chez saint Irénée," RSPT 76.3 (1992): 421-42.

La theologie d'Irenee. Lecture des Ecritures en reponse a l'exegese gnostique: Une approche trinitaire. Paris: Éditions du Cerf, 1994.

"Le passage de premier Adam au second Adam comme expression de salut chez Irénée Lyon.” VC 52.4 (1998): 418-29.

Farkasfalvy, D. “Theology of Scripture in St. Irenaeus.” RevB 68 (1968): 319-33.

-Inspiration and Interpretation: A Theological Introduction to Sacred Scripture. Washington D.C.: The Catholic University of America Press, 2010.

Farmer, W. R. "Galatians and the second century development of the regula fidei." SecCen 4.3 (1985): 143-70.

Farrow, D. B. "St Irenaeus of Lyons: The Church and the World." ProEc 4 (1995): 33355.

. "The Doctrine of the Ascension in Irenaeus and Origin." ARC 26 (1998): 31-50.

Faur, J. Golden Gloves with Silver Dots: Semiotics and Textuality in Rabbinic Tradition. Bloomington: Indiana University Press, 1986. 
Fishbane, M. Biblical Interpretation in Ancient Israel. Oxford: Clarendon Press, 1985.

Ferguson, T. C. K. "The Rule of Truth and Irenaean Rhetoric in Book 1 of Against Heresies." VC 55.4 (2001): 356-75.

Ferlay, P. “Irénée de Lyon exegete du quatrième évangile.” NRT 106.2 (1984): 222-34.

Flesseman-van Leer, E. Tradition and Scripture in the Early Church. Assen: Van Gorcum, 1954.

Fossum, J. "Gen. 1,26 and 2,7 in Judiasm, Samaritanism and Gnosticism." JSJ 16.2 (1985): 203-39.

Frei, Hans. The Eclipse of Biblical Narrative: A Study in Eighteenth and Nineteenth Century Hermeneutics. New Haven: Yale University Press, 1974.

Frishman, J. The Book of Genesis in Jewish and Oriental Christian Interpretation. Louvin: Peeters, 1997.

Gambero, L. Mary and the Fathers of the Church: The Blessed Virgin Mary in Patristic Thought. Translated by Thomas Buffer. San Francisco: Ignatius, 1999.

Gamble, Harry. Books and Readers in the Early Church: A History of Early Christian Texts. New Haven, CT: Yale University Press, 1997.

Giere, S. D. A New Glimpse of Day one: Intertextuality, History of Interpretation, and Genesis 1:1-5. Berlin: De Gruyter, 2009.

Giverson, S. “The Apocryphon of John and Genesis.” StuTh 17 (1963): 60-76.

Gonzalez-Faus, J. I. Creación y progreso en la teología de San Ireneo. Barcelona: San Cugat del Valles, 1968.

- Carne de dios: Significado Salvador de la Encarnación en la teología de San Ireneo. Barcelona: San Cugat del Valles, 1968.

Graham, S. L. “Structure and Purpose of Irenaeus' Epideixis." StuPat 36 (2001): 210-21. . "Irenaeus and the Covenants: 'Immortal Diamond." StuPat 40 (2006): 39398.

. "Irenaeus as Reader of Romans 9-11." In Early Patristic Readings of Romans, 87-113. Edited by K. L. Gaca and L.L. Welborn. New York: T\&T Clark, 2005.

Grant, R. M. “Scripture, Rhetoric and Theology in Theophilus.” VC 13 (1959): 33-45. “"Irenaeus and Hellenistic Culture." HTR 42 (1949): 41-51.

Gnosticism and the Early Church. New York: Columbia University Press, 1966. 
. Greek Apologists of the Second Century. London: SCM, 1988.

. Irenaeus of Lyons. London: Routledge, 1997.

Grant, R. M. and D. Tracy. A Short History of the Interpretation of the Bible. Philadelphia: Fortress Press, 1984.

Greer, R. A. "The dog and the mushrooms: Irenaeus's view of the Valentinians assessed.” In Rediscovery of Gnosticism, 146-171. Vol. 1. Leiden: Brill, 1980.

Grillmeier, A. Christ in Christian Tradition: From the Apostolic age to Chalcedon. Vol. 1. Translated by J. Bowden. Atlanta, GA: John Knox Press, 1975.

Grivel, C. "Thèses préparatoires sur les intertexts." Dialogizität, Theorie und Geschichte der Literatur und der schönen Künste, 237-48. Edited by R. Lachmann. Munich: Fink, 1982.

Guevin, B. “The natural law in Irenaeus of Lyons' Adversus haereses: a metaphysical or a soteriological reality?" StuPat 36 (2001): 222-225.

Häkkinen, S. “Ebionites.” In A Companion to Second-Century Christian 'Heretics,' 247-78. Leiden: Brill, 2005.

Harnack, A.von. "Der Presbyter-Prediger des Irenäus (IV,27,1-32,I): Bruch-stücke und Nachklänger der ältesten exegetisch-polemischen Homilien." In Philotesia: Paul Kleinert zum LXX Geburtstag, 1-37. Berlin: Trowitzsch, 1907.

. History of dogma. 7 vols. New York: Dover Publications, 1961.

- Marcion: The Gospel of the Alien God. Translated by J. E. Steely and L. D. Bierma. Durham: Labyrinth Press, 1990.

Hart, T. "Irenaeus, recapitulation and physical redemption." In Christ in our Place, 152-81. Allison Park, PA: Pickwick Publications, 1989.

Hays, R. Echoes of Scripture in the Letters of Paul. New Haven: Yale University Press, 1989.

"Die Befreiung Israels im lukanischen Doppelwerk: Intertextuelle Narration als kulturkritische Praxis." In Die Bibel im Dialog der Schriften: Konzepte intertextueller Bibellektüre, 117-136. Tübingen: A. Francke, 2005.

Hatina, T. R. "Intertextuality and Historical Criticism in New Testament Studies: Is there a Relationship?" BibInt 7 (1999): 28-43.

Hauke, M. Heilsverlust in Adam: Stationen griechischer Erbsündlehre: Irenäus-OrigenesKappadozier. Paderborn, Germany: Bonifatius, 1993.

Hefner, P. “Theological Methodology and St. Irenaeus.” JR 44 (1964): 294-309. 
Herra, S. Irénée de Lyon Exégète. Etude Historique: Paris, 1920.

Hill, C. E. "Polycarp contra Marcion Irenaeus' Presbertial Source in AH 4.27-32." SP 40 (2006): 399-412.

. From the Lost Teaching of Polycarp: Identifying Irenaeus' Apostolic Presbyter and the Author of Ad Diognetum. Tübingen: Mohr Siebeck, 2006

"Irenaeus of Lyons." In The Johannine Corpus and the Early Church, 95-118. Oxford: Oxford University Press, 2004.

Hitchcock, F. R. M. and H. B. Swete. Irenaeus of Lugdunum: A Study of His Teaching. Cambridge: University Press, 1914.

"Loof's Theory of Theophilus of Antioch as a Source of Irenaeus." JTS 38 (1937): 130-39; 255-66.

Hoh, J. “Die Lehre des hl. Irenäus uber das Neue Testament.” NTA 7 (1919): 189-197.

Hollander, J. The Figure of Echo: A Mode of Allusion in Milton and After. Berkeley: University of California Press, 1981.

Holsinger-Friesen, T. Irenaeus and Genesis: A study of Competition in Early Christian Hermeneutics. Winona Lake, IN: Eisenbrauns, 2009.

Holzhausen, J. "Irenäus und die valentinianische Schule: zur Praefatio von Adv. Haer. 1." VC 55.4 (2001): 341-55.

Houssiau, A. “L’exégèse de Mt 11:27b selon S. Irénée.” ETL 29 (1953): 328-54.

- La christologie de Saint Irénée. Louvain: Publications universitaires de Louvain, 1955.

Irwin, W. “Against Intertextuality.” PL 28 (2004): 227-42.

Jacobsen, A.-C. "The Importance of Genesis 1-3 in the Theology of Irenaeus" ZAC 8 (2004): 299-316.

"The Philosophical Argument in the Teaching of Irenaeus on the Resurrection of the Flesh." StuPat 36 (2001): 256-261.

Javierre, A. M. “'In ecclesia': Ireneo, Adv haer 3, 3, 2”, In Comunione interecclesiale collegialité - primato ecumenismo, 221-317. Rome: LAS, 1972.

Jourjon, M. “Saint Irénèe lit la Bible.” In Le monde grec ancien et la Bible, 153-70. Paris: Beauchesne, 1984.

Kannengiesser, C. “The «Speaking God» and Irenaeus' Interpretative Pattern: the Reception of Genesis.” ASE 15.2 (1998): 337-52. 
Handbook of Patristic Exegesis. Brill: Leiden, 1999.

Kelly, J. N. D. Early Christian Doctrines. 5th ed. San Francisco: Harper \& Row, 1978.

King, K. L. What Is Gnosticism? Cambridge: Harvard University Press, 2003.

—. Images of the feminine in Gnosticism. Philadelphia, Fortress Press, 1988.

Klebba, E. Die Anthropologie des hl. Irenaeus. Münster: Verlang von Heinrich Schöningh, 1894.

Kristeva, J. Desire in Language: A Semiotic Approach to Literature and Art. New York: Columbia University Press, 1980.

- Revolution in Poetic Language. Paris: Éditions du seuil, 1974.

Kristeva, J. and T. Moi. The Kristeva Reader. Oxford: Blackwell, 1986.

Kugel, J. and R. Greer. Early Biblical Interpretation. Phiadelphia: Westminister Press, 1986.

Lampe, G. W. H. A Patristic Greek Lexicon. New York: Clarendon, 1961.

Lanne, D. E. “La ‘xeniteia' d’Abraham dans l’oeuvre d'Irénée.” Irén 47 (1974): 163-87.

" "Nom de Jésus-Christ et son invocation chez saint Irénée de Lyon." Irén 48.4 (1975)" 447-67.

. “Saint Irénée de Lyon, artisan de la paix entre les Églises.” Irén 69 (1996): 451-76.

Lassiat, “L’ Anthropologie d'Irénée.” NRT 100 (1978) 399-417.

. Promotion de l'homme en Jésus Christ d'après Irénée de Lyon. Tours: Mame, 1974.

Lawson, J. The Biblical Theology of Saint Irenaeus. London: Epworth Press, 1948.

Layton, B. The Gnostic Scriptures. Garden City, NY: Doubleday, 1995.

Logan, A. H. B. Gnostic Truth and Christian Heresy: A study in the History of Gnosticism. Edinburgh: T\&T Clark, 1996.

Loewe, W. P. "Myth and Counter-Myth: Irenaeus' Story of Salvation." In Interpreting Tradition: The Art of Theological Reflection, 39-54. Chico, CA: Scholars Press, 1984.

“Irenaeus' Soteriology: Christus Victor Revisited.” AThR 67.1 (1985): 1-15. 
Loofs, F. Theophilus von Antiochien adversus Marcionem und die anderen theologischen Quellen bei Irenaeus. Lepzig: J. C. Hinrichs, 1930.

Luckhart, R. "Matthew 11,27 in the 'Contra Haereses' of Saint Irenaeus." RUO 23 (1953): 65-79.

Luttikhuizen, G. P. Gnostic Revisions of Genesis Stories and Early Jesus Traditions. Leiden: Brill, 2006.

Luz, U. Matthew 21-28: A Commentary. Translated by James E. Crouch. Minneapolis: Augsburg Fortress, 2005.

MacDonald, N. "Israel and the Old Testament Story in Irenaeus' Presentation of the Rule of Faith." JTI 3.2 (2009): 281-98.

Macrae, G. W. "Why The church Rejected Gnosticism." in Jewish and Christian SelfDefinition, 126-33. Edited by E. P. Sanders. London: S. C. M. Press, 1980.

Margerie, B. de. Introduction à L'historie de L'exégèse: 1. Les Pères grecs et orientaux. Paris: Les Éditions du Cerf, 1980.

Markschies, C, Valentinus Gnosticus?: Untersuchungen zur valentinianischen Gnosis mit einem Kommentar zu den Fragmenten Valentins. Tübingen: Paul Siebeck, 1992.

—. Gnosis: An Introduction. New York: T\&T Clark, 2003.

Markus, R. A. "Pleroma and fulfillment: the significance of history in St. Irenaeus' opposition to Gnosticism.” VC 8.4 (1954): 193-224.

Martens, P. "Revisiting the Allegory/Typology Distinction: The Case of Origen." JECS 16.3 (2008): 283-317.

May, G. Creatio ex Nihilo: The Doctrine of 'Creation out of Nothing' in Early Christian Thought. Translated by A. S. Worrall. Edinburgh: T\&T Clark, 1994.

McHugh, J. "A Reconsideration of Ephesians 1,10b in Light of Irenaeus." In Paul and Paulinism: Essays in Honour of C.K. Barrett, 302-9. Edited by M.D. Hooker and S.G. Wilson. London: SPCK, 1982.

Meijering, E. P. “God Cosmos History: Christian and Neo-Platonic Views on Divine Revelation." In God Being History: Studies in Patristic Philosophy, 52-80. New York: American Elsevier, 1975. “Irenaus zum zeitlichen Anfang der Welt." VC 54.1 (2000): 1-11.

Miller, P. C. "Words with an Alien Voice: Gnostics, Scripture and Canon." JAAR 57 (1989): 459-83.

Minns, D. Irenaeus. London, G. Chapman, 1994. 
Moringiello, S. D. “Irenaeus Rhetor." Unpublished Dissertation. University of Notre Dame, 2008.

Moyise, S. "Intertextuality and the Study of the Old Testament in the New

Testament." In Old Testament in the New Testament: Essays in Honour of J.L. North, 14-41. Edited by Stephen Moyise. Sheffield: Sheffield Academic Press, 2000.

Mutschler, B. Irenäus als johanneischer Theologe. Tübingen: Mohr Siebeck, 2004.

. Das Corpus Johnneum bei Irenäus von Lyon. Tübingen: Mohr Siebeck, 2006.

Nautin, P. “Irénée, Adv haer, III 3,2: Eglise de Rome ou église universelle?” RHR 151 (1957): 37-78.

Nielson, J. T. Adam and Christ in the Theology of Irenaeus of Lyons. Assen: Van Gorcum, 1968.

Normann, R. Irenäus als Paulusinterpret: zur Rezeption und Wirkung der paulinischen und deuteropaulinischen Briefe im Werk des Irenäus von Lyon. Tubingen: JCB Mohr, 1994.

Norris, R. A. God and World in Early Christian Theology. New York: The Seabury Press, 1965.

. "Irenaeus' use of Paul in his polemic against the Gnostics." In Paul and the legacies of Paul, 79-98. Edited by W.S. Babcok. Dallas: SMU Press, 1990.

. “Theology and Language in Irenaeus of Lyon.” AThR 76.3 (1994): 285-97

. "The Insufficiency of Scripture: Adversus Haereses 2 and the Role of Scripture in Irenaeus's Anti-gnostic Polemic." In Reading in Christian Communities, 63-79. Notre Dame: University of Notre Dame Press, 2002.

Olsen, M. J. Irenaeus, the Valentinian Gnostics and the Kingdom of God (A.H. Book V): The Debate About 1 Corinthians 15:50. New York: Mellen Biblical Press, 1992.

O’Neil, J. C. "How early is the doctrine of creatio ex nihilo?" JTS 53.2 (2002): 449-65.

Orbe, Antonio S. J., "El hombre ideal en la teología de san Ireneo.” Greg 43 (1962): 464-68.

. "El pecado de Eva, signo de divieion." OCP 29 (1963): 305-30.

"Homo nuper factus: En torno a s. Ireneo, Adv. haer. IV,38,1." Greg 46 (1965): 481-544.

Anthropogía de San Ireneo. Madrid: Biblioteca des Autores Cristianos, 1969. 
"La Revelacion Del Hijo Por el Padre Segun San Ireneo (Adv. Haer. IV,6): Para la exegesis precivena de Matt 11,27." In Theologia De San Ireneo IV:

Traducción y Comentario del Libro IV del «Adversus haereses», 50-103. Madrid:

Biblioteca de Autores Cristianos, 1996, originally published in Greg 51 (1970): 5-83.

. "Ipse tuum calcabit caput (S. Ireneo y Gén 3:15)." Greg 52 (1971): 85-149; 215-69.

Parabolas evangelicas in San Ireneo. 2 vols. Madrid: Biblioteca de Autores Cristianos, 1972.

. “San Ireneo y la Creación de la material." Greg 59 (1978): 71-127.

. "Errores de los ebionitas (Analisis de Ireneo, Adversus haereses, V, 1, 3)." Mar 41 (1979): 147-70.

_. “San Ireneo y la doctrina de la reconciliación.” Greg 61.1 (1980): 5-50.

. "Cinco exegesis Ireneanas de Gen 2:17b adv. haer. V 23, 1-2." Greg (1981):

75-113.

. "La Virgen María abogada de la virgen Eva; en torna a s. Ireneo adv. haer. V. 19, 1).” Greg 63 (1982): 453-506.

- Teología de San Ireneo: Comentario al Libro V del «Adversus haereses». Madrid: Biblioteca de Autroes Crisianos, 1985.

Theología de San Ireneo: Comentario al libro V del Adversus Haereses. 3 vols. Madrid: Biblioteca des Autores Cristianos, 1988.

. "Gloria Dei vivens homo: Análisis de Ireneo, adv. haer. IV, 20, 1-7." Greg 73.2 (1992): 205-68.

“En torno a los Ebionitas." Aug 33 (1993): 315-37.

. "El Espíritu en el bautismo de Jesús (en torno a san Ireneo)." Greg 76.4 (1995): 663-99.

47-68.

“El signo de Jonás según Ireneo.” Greg 77.4 (1996): 637-57.

Theología de. San Ireneo: Comentario al libro IV del Adversus Haereses. Madrid: Biblioteca des Autores Cristianos, 1996.

Osborn, E. "Reason and the Rule of Faith." In The Making of Orthodoxy. Festschrift for Henry Chadwick, 40-61. Edited by R. Williams. Cambridge: Cambridge University Press, 1989. 
. Irenaeus of Lyons. Cambridge: Cambridge University Press, 2001.

Pagels, E. The Johannine Gospel in Gnostic Exegesis. New York: Abingdon Press, 1973.

. The Gnostic Paul: Gnostic Exegesis of the Pauline Letters. Philadelphia: Fortress Press, 1975.

"Exegesis and Exposition of the Genesis Creation Accounts in Selected Texts from Nag Hammadi.” In Nag Hammadi, Gnosticism, and Early Christianity, 257-286. Edited by C. Hedrick and R. Hodgson. Wipf \& Stock Publishers, 2005.

Painchaud, L. “The Use of Scripture in Gnostic Literature.” JECS 4.2 (1996): 129-47.

Pelikan, J. Mary Through the Centuries: Her place in the History of Culture. New Haven, CT: Yale University Press, 1996.

Perkins, P. "Gnosticism and the Christian Bible." In The Canon Debate, 355-71. Edited by L. M. McDonald and J. A. Sanders. Peabody, MA: Hendrickson, 2002.

Irenaeus and the Gnsotics: Rhetoric and Composition in Adversus Haereses Book One." VC 30 (1976): 103-200.

. 'Ordering the cosmos: Irenaeus and the Gnostics.' In Nag Hammadi, Gnosticism, and Early Christianity, ed. C.W. Hedrick, J. Hodgson, 221-38. Peabody, MA: Hendrickson, 1986.

_. "Review of Rolf Noormann, Irenäus als Paulusinterpret." CBQ 58 (1996): 76264.

Petersen, W. L. "Tatian the Assyrian." In A Companion to Second-Century Christian 'Heretics,' 125-58. Leiden: Brill, 2005.

Plagineux, J. “La doctrine mariale de saint Irénée.” RSR 44 (1970): 179-89.

Poffet, J. M. “Indices de reception de l'évangile de Jean au IIe siècle, avant Irénée.” In Communauté johannique et son histoire, 305-26. Genova: Labor et Fides, 1990.

Poirier, P. H. "Pour une histoire da la lecture pneumatologique de Gn 2:7: Ouelques jalons jusqu’à Irénée de Lyon.” REA 40 (1994): 1-22.

Porter, S. E. "The Use of the Old Testament in the New Testament: A Brief Comment on Method and Terminology." In Early Christian interpretation of the scriptures of Israel: investigations and proposals. Edited by Craig A. Evans, James A. Sanders. Sheffield: Sheffield Academic Press, 1997.

"Further Comments on the Use of the Old Testament in the New Testament," in The Intertextuality of the Epistles: Explorations of Theory and Practice, 98-110. Edited by T. L. Brodie, D. R. MacDonald, and S. E. Porter. Sheffield: Sheffield Phoenix Press, 2007. 
"Allusions and Echoes." In As it is Written: Studying Paul's use of Scripture, 29-40. Leiden: Brill, 2008.

Pratscher, W. "The Second Epistle of Clement." In The Apostolic Fathers: An Introduction, 71-90. Waco, Texas: Baylor University Press, 2010.

Presley, S. “The Lost Sheep who is Found: Irenaeus' Intertextual Reading of Genesis 3 in Adversus Haereses 3.23.1-8." StuPat 51 (2011): Fourthcoming.

. "The Rule of Faith and Irenaeus's Demonstration of the order and connection of the scriptures." ORA (2010): 48-66.

Pretto, E. La Lettera ai Romani, cc. 1-8, nell “Adversus Haereses" d'Ireneo. Bari: Istituto di Litteratura Cristiana Antica, 1971.

Purves, J. G. M. "The Spirit and the Imago Dei: Reviewing the Anthropology of Irenaeus of Lyons.” EvQ 68 (1996): 99-120.

Quasten, J. Patrology. Allen, TX: Christian Classics, 1983.

Rahner, H. Symbole der Kirche. Salzburg: Otto Muller, 1964.

Ramos-Lissón, D. “Le Role de la femme dans la théologie de saint Irénée.” StuPat 21 (1989): 163-74.

Reventlow, H. G. History of Biblical Interpretation: From the Old Testament to Origen. Vol. 1. Atlanta, Society of Biblical Literature, 2009. Originally published: Epochen der Bibelauslegung Band 1: Vom Alten Testament bis Origenes. Müchen: Verlag C. H. Beck, 1990.

Reynders, B. Vocabulaire de la "Demonstration" et des fragments de saint Irénée. Chevetogne: Editions de Chevetogne, 1958.

. Lexique comparé du texte grec et des versions latine, arménienne et syriaque de l'Adversus Haereses de saint Irénée. Louvain: Peeters, 1963.

Rhee H. Early Christian Literature: Christ and Culture in the Second and Third Centuries. London: Routledge, 2005.

Robbins, G. A. Genesis 1-3 in the History of Exegesis: Intrigue in the Garden. Lewiston, NY: E. Mellen Press, 1988.

Robert, R. "Le témoignage d'Irénée sur la formation des évangiles." RThom 87.2 (1987): 243-59.

Roberts, C. H. and T.C. Skeat. The Birth of the Codex. London: Oxford University Press, 1983.

Robinson, J. M. The Nag Hammadi Library in English. San Francisco: Harper, 1991. 
Roldanus, J. “L'héritage d'Abraham d'après Irénée.” In Text and Testimony: Essays on New Testament and Apocryphal Literature in Honour of A. F. J. Klijin, 212-24. Edited by T. Baarda. Kampen: Kok, 1998.

Rondeau, M.-J. Les commentateurs patristiques du Psautier (IIIe-Ve siècls). 2 Vol. Rome: Oriental Institute, 1982, 1985.

Rousseau, A. “L'Eternité des peines de l'enfer et l'immortalité naturelle de l' âme selon saint Irénée.” NRT 99 (1977) 834-64.

Rudolph, K. Gnosis: The Nature and History of Gnosticism. Edinburgh: T\&T Clark, 1983.

"Bibel und Gnosis zum Verständnis Jüdisch-Biblischer Texte in Der Gnostischen Literatur, vornehmlich aus Nag Hammadi." In Gnosis Und Spätantike Religionsgeschichte: Gesammelte Aufsätze, 190-209. Leiden: Brill, 1996.

Ruiz, G. “'Ma puissance se déploie dans la faiblesse' (2 Cor 12:9): An Interprétation d'Irénée de Lyon." In Recherches et tradition: Mélanges patristiques offerts à Henri Crouzel, S.J. sous la direction d'A. Dupleix, 259-69. Paris: Neauchesne, 1992.

“L’enfance d'Adam selon saint Irénée de Lyon.” BLE 89 (1998): 97-115.

Sagnard, F. M. M. La gnose valentinienne et le témoignage de saint Irénée. Paris: J. Vrin, 1947.

Sanders, J. N. The Fourth Gospel in the Early Church (Its Origin \& Influence on Christian Theology up to Irenaeus). Cambridge: University Press, 1943.

Schmidt, W. A. Die Kirche bei Irenäus: akademische Abhandlung. Helsingfors, 1934.

Schoedel, W. R. "Philosophy and Rhetoric in the Adversus Haereses of Irenaeus." VC 12 (1959): 22-32.

“Theological Method in Irenaeus (Adversus haereses 2.25-28)." JTS 35 (1984): 31-49.

Seeberg, R. Lehrbuch der Dogmengeschichte. Lepzig: 1908.

Sesboüe, B. Tout Récapituler dans le Christ: Christologie et sotériologie d'Irénée de lyon. Paris: Desclée, 2000.

Shotwell, W. A. The Biblical Exegesis of Justin Martyr. London: SPCK, 1965.

Simonetti, M. Biblical Interpretation in the Early Church: An Historical Introduction to Patristic Exegesis. Edited by A. Bergquist and M. Bockmuehl. Translated by John A. Hughes. Edinburgh: T\&T Clark, 1994. 82. 
Siniscalco, M. “La parabola del figlio prodigo (Lc 15:11-32) in Ireneo.” SMSR 38.2 (1967): 5326-53.

Skeat, T. C. "Irenaeus and the Four-Gospel canon." NovT 34 (1992): 194-99.

Slusser, M. “The Exegetical Roots of Trinitarian Theology.” TS 49 (1988) 461-476. “How much did Irenaeus learn from Justin?" StuPat 40 (2006): 515-20.

Smith, C. R. "Chiliasm and recapitulation in the theology of Ireneus [sic]." VC 48 (1994): 313-331.

Smith, D.A. "Irenaeus and the Baptism of Jesus." TS 58 (1997): 618-42.

Smith, J. P. “Hebrew Christian Midrash in Ireaneus Epid, 43.” Bib 38 (1957): 24-34.

Stanton, G. "Jesus Traditions and Gospels in Justin Martyr and Irenaeus." In The Biblical Canons. Edited by J. M. Auwers and J. H. de Jonge. Leuven: Leuven University Press, 2003.

Stead, M. R. The Intertextuality of Zechariah 1-8. New York: T\&T Clark, 2009.

Steenberg, M. C. “Cosmic Anthropology: Gen 1-11 in Irenaeus of Lyons with special reference to Justin, Theophilus and select Gnostic contemporaries." Unpublished dissertation. University of Oxford, 2003.

. "Children in Paradise: Adam and Eve as 'Infants' in Irenaeus of Lyons." JECS 12.1 (2004): 1-35.

. "The Role of Mary as Co-recapitulator in St. Irenaeus of Lyons." VC 58 (2004): 117-37.

. "To Test or Preserve?: The Prohibition of Gen 2:16-17 in the Thought of Two Second-Century Exegetes." Greg 86 (2005): 723-41.

—. Irenaeus on Creation. Leiden: Brill, 2008.

- Of God and Man. New York: T\&T Clark, 2009.

Thomassen, E. The Spiritual Seed: The Church of the 'Valentinians'. Leiden: Brill, 2006.

Tiessen, T. L. Irenaeus on the Salvation of the Unevangelized. London: The Scarecrow Press, 1993.

"Gnosticism and Heresy: The Response of Irenaeus." In Hellenization Revisited, 339-59. Lanham, MD: University Press of America, 1994. 
Todorov, T. Mikhail Bakhtin: the dialogical principle. Manchester: Manchester University Press, 1984.

Torrance, T. F. "Kerygmatic Proclamation of the Gospel: The Demonstration of Apostolic Preaching." In Divine Meaning: Studies in Patristic Hermeneutics, 56-74. Edinburgh: T\&T Clark, 1995.

Tortelli, K. M. “Some methods of interpretation in St Irenaeus.” VetCh 30 (1993): 12332.

Tosaus Abadía, J. P. Cristo y el universo: estudio lingüístico y temático de Ef 1:10b, en Efesios y en la obra de Ireneo de Lión. Univ Pontificia de Salamanca, 1995.

Tremblay, R. “La signification d' Abraham dans l'oeuvre d'Irénée de Lyon.” Aug 18 (1978): 434-57.

——."Le martyre selon saint Irénée de Lyon.” StuM 16 (1978): 167-89.

- La manifestation et la vision de Dieu selon saint Irénée de Lyon. Münster: Aschendorff, 1978.

. Irénée de Lyon: «L'empreinte des doigts de Dieu». Rome: Editiones Academiae Alfonsianae, 1979.

Tripp, D. “The Original Sequence of Irenaeus ‘Adversus Haereses' 1: A Suggestion.” SecCen 8 (1991): 157-62.

Tull (Willey), P. Remember the Former Things: The Recollection of Previous Texts in Second Isaiah. Atlanta: Scholars Press, 1997.

Turner, J. D. "Time and History in Sethian Gnosticism." In For the Children, Perfect Instruction, 203-14. Edited by H.-G Bethge. Leiden: Brill, 2002.

Valle, G. A Study in Anti-Gnostic Polemics: Irenaeus, Hippolytus, and Epiphanius. Waterloo, Ontario: Wilfrid Laurier University Press, 1981.

Van Unnik, W. C. Newly Discovered Gnostic Writings: A preliminary servey of the Nag Hammadi find. London: SCM Press, 1960.

. "An interesting document of Second Century Theological Discussion (Irenaeus, Adv. Haer. 1.10.3).” VC 31 (1977): 196-228.

."Theological Speculation and its Limits." In Early Christian Literature and the Classical Tradition, In Honorem Robert M. Grant, 33-43. Paris: Beauchesne, 1979.

Van Wolde, E. "Texts in Dialogue with Texts: Intertextuality in the Ruth and Tamar Narratives." BibInt 5.1 (1997): 1-28. 
Voelz, J. W. "Multiple Signs and Double Texts: Elements of Intertextuality.” In Intertextuality In Biblical Writing: Essays in honour of Bas van Iersel. Uitgeversmaatschappij J. H. Kok: Kampen, 1989.

Vogel, J. "The Haste of Sin, the Slowness of Salvation: An Interpretation of Irenaeus and the Fall and Redemption." AThR 89 (2007): 443-59.

Vogt, R. J. “Die Geltung dea Alten Testaments bei Irenäus von Lyon.” ThQ 160 (1980): 17-28.

Wanke, D. Das Kreuz Christi bei Irenäus von Lyon. New York: De Gruyter, 2000.

Watson, F. "Is there a Story in these Texts?" In Narrative dynamics in Paul: a critical assessment, 231-39. Edited by B. Longenecker. Louisville, KY: Westminster John Knox, 2002.

Weinandy, Thomas. "St. Irenaeus and the Image Dei: The Importance of Being Human.” Logos 6.4 (2003): 15-34.

Weiss, Friedrich. Frühes Christentum und Gnosis: Eine rezeptionsgeschichtliche Studie. Tübingen: Mohr-Siebeck, 2008.

Wendt, H. H. Die christlich Lehre von der menschlichen Volkommenhiet. Göttingen, 1882.

Werner, J. Der Paulinismus des Irenaeus. Leipzig, 1889.

Wilchen, J. “Irenaeus' Doctrine of a 'living man.” ACR 59 (1982): 74-82.

Williams, J. Biblical Interpretation in the Gnostic Gospel of Truth From Hag Hammadi. Atlanta: Scholars Press, 1988.

Williams, M. A. Rethinking "Gnosticism": An Argument for Dismantling a Dubious Category. Princeton: Princeton University Press, 1996.

Wilson, R. M. “The Early History of the Exegesis of Gen. 1:26.” StuPat 1 (1957): 420-37.

Wingren, G. Man and the Incarnation. A study in the Biblical Theology of Irenaeus. Translated by R. Mackenzie. Philadelphia: Muhlenberg Press, 1959.

Wood, A. S. "Eschatology of Irenaeus.” EvQ 41 (1969): 30-41.

Xintaras, Z. C. "Man, the Image of God: According to the Greek Fathers." GOTR 1.1 (1954): 48-62.

Young, F. The Art of Performance: Towards A Theology of Holy Scripture. London: Darton, Longman and Todd, 1990.

Biblical Exegesis and the Formation of Christian Culture. New York: Cambridge University Press, 1997. 
